\title{
CATÁLOGO \\ DE LAS EXPOSICIONES DE ARTE \\ EN 1971
}

SUPLEMENTO AL NÚM. 41 DE LOS

ANALES DEL INSTITUTO DE INVESTIGACIONES ESTÉTICAS

MÉXICO, 1972 
DOI: http://dx.doi.org/10.22201/iie.18703062e.1972.sup1

Primera edición: 1973

DR (C) 1973, Universidad Nacional Autónoma de México

Ciudad Universitaria. México 20, D. F.

Dirección General de Publicaciones

Impreso y hecho en México 
Las exposiciones de arte en México se han mantenido en un nivel, en cuanto ẩ número de ellas, desde hace algunos años (véase el Catálogo de 1969), y en 1971 estuvieron a la misma altura, pues se presentaron en total 362 exposiciones.

E1 Instituto Nacional de Bellas Artes, y sus dependencias, organizó 90 exposiciones. En el Palacio de Bellas Artes se instalaron las siguientes: Bernice Kolko (fotos), Libros de la India, Fred Powell, Valdés Galindo, La familia del hombre, Homenaje a Manuel Rodríguez Lozano, Ernesto Carrcón, Grabado Japonés Contemporáneo, Gertrude Duby, Oscar Meraldi, Boanerges Mideros, Primer Salón de la historieta mexicana, Baruj Salinas, Pablo O'Higgins, Confrontación de Arte Infantil, Arte Gráfico Polaco, Litografías, Primer Salón Nacional de la Estampa, El Universo de la Universidad (fotos), Realidad pictórica del Ecuador, Tres pintores tabasqueños, Un año de labor de la Escuela Nacional de pintura y escultura "La Esmeralda", Grupo de 10 ceramistas.

A continuación se consideran otras dependencias del Instituto Nacional de Bellas Artes $y$ las exposiciones que presentaron.

Musco de Arte Moderno INBA: en Chapultenec: Pintores Contemporáneos Holandeses, 20 artistas italianos, Aarón Piña Mora, Fernando Ramos Prida, Arte Moderno de Bélgica, Carlos Alvarado Lang, Pedro Preux, Adolfo Quinteros, Homenaje a Agustín Lazo, Tres pintores de Galicia, Carlos Tejeda, Eric Renner, Estanislao Contreras, Primer Salón Mexicano del Diseño, María Izquierdo, Ezequiel Negrete, Remedios Varo, Primer Salón Anual de Escultura, Augusto Rodin, Arte fantástico y surrealista de México, Raúl Anguiano, Arte Chileno. Total 22 exposiciones.

Salón de la Plástica Mexicana, INBA: Juan O'Gorman, Erasto Cortés Juárez, Ángel Pichardo Dávila, Paulina Trejo, Francisco Mora, María Teresa Toral, Salón de Pintura 1971, Salón de Grabado 1971, Salones de pintura, escultura y dibujo 1971, Alfonso Ayala, Fidencio Castillo, Leonel Maciel. Total 13 exposiciones.

Galería Chapultepec, INBA: Jesús Contreras Peña, Alejandro Creel, Neftalí Moreno Aparicio, Luis González Zárate, José Julio Gaona, Mabel, Nancy Van, Maxime Wishnick, VI Concurso Nacional, Gilberto Ramírez, Francisco Marmata, Tres caricaturistas en la pintura, Carlos Cantú, Elva Gaona, Amalia Franco, Juan Castañeda, Esteban Soto Villafaña, Miguel Angel Brenes, Fidel Corpus Nova. Total 19 exposiciones.

Galería José Ma. Velasco, INBA: Nacho Hernández, Colectiva 71, Teódulo Rómulo, Eliú Vega, Flaviano E. Coral-R., 11 Pinturas Contemporáneas, La expresión 
plástica infantil en la Escuela Primaria, Acuarela 71, Exposición Colectiva, Arturo Estrada, Fiesta, Luis Torreblanca, Luis Lemus. Total 13 exposiciones.

En el Museo de las Culturas, SEP: se instalaron 13 exposiciones, que fueron las siguientes: colectiva, Valetta, Pavlata, Chappie Angulo, Exposición final, Xilonen, Exposición colectiva permanente, Taller de grabado infantil, Exposición del círculo de Estudios Antropológicos, Exposición de trabajos del $2^{\circ}$ ciclo de talleres sabatinos 1971, Taller de gráfica infantil, Tercer ciclo de talleres sabatinos, Exposición tres legados culturales. Total 13 exposiciones.

Seminario de Cultura Mexicana, SEP: Exposición de Dora Gómez de Setien.

Museo Nacional de Antropología e Historia, SEP: Exposición de obras de Roberto Montenegro.

La Universidad Nacional Autónoma de México, presentó varias exposiciones en sus dependencias.

Biblioteca Nacional, UNAM: El libro Belga, Exposición biblio-iconográfica de Paul Valéry.

Museo Universitario de Ciencias y Artes, UNAM: Exposición de libros científicos $\mathrm{y}$ técnicos, publicaciones francesas.

Escuela Nacional de Artes Plásticas, UNAM: Per Anderson, Lucio Acosta Cerra, Guillermo Téllez, Akihiko Nagata, José Luis Neyra, Grabado Contemporáneo Checoslovaco, Richard R, Benda.

Casa del Lago, UNAM: Edmundo Aquino, Humberto Peraza, Leslie-Krius.

Facultad de Quimica, UNAM: Exposición de libros británicos.

Las Galerias de la Ciudad de México, dependientes del Departamento del Distrito Federal, estuvieron muy activas pues presentaron más de 50 exposiciones, que son las siguientes:

Bernice Kolko, Irene Becerril, Ma. Teresa Toral, Manuel González, Ruiz Vidaurri, Arturo Ramírez Juárez, Javier Padilla, Genoveva Cámara, Jacia Frid, Holanda País y Pueblo, Angel Boliver, Homenaje a Emiliano Zapata, Rosa María Sustacta, Roher, José Luis Neira, Per Anderson, Federico Díaz Cañedo, Luis Bolland, Alicia Saloma, Tanguma, Daniel Machuca, Irene Arias, Alumnos del Taller de la Gráfica Popular, Gandoulf Ramírez, Yolanda Savin, Manuel Muñoz Olivares, La patria (colectiva), Ma. Elena Massad, Jorge Edgardo Ramírez, Irma Domínguez, Carteles Internacionales, Susana Campos, Miguel Hernández Urbán, David Pimentel, Manuel Manilla, Angel Bracho, Arte en el Hogar, Carlos Olachea, Miguel Hernández Urbán, Jeanine Houard, Jean Leh Mans, Esmindo Castillo, Grupo Ultra.

Museo de la Ciudad de México: La ciudad de México de José Guadalupe Posada. 
Los Institutos Culturales que varios países tienen en la Ciudad de México, estuvieron activos como en años anteriores.

Instituto Mexicano-Norteamericano de Relaciones Culturales, $A$. C.:

Club Fotográfico de México, 22a Exposición Anual de Artes Plásticas de la Universidad de las Américas, Carlos Cuéllar, Tadeuz Lapinski, Lola Cueto, Carlos Naumer, Lo Cursi, William Quinn, Charles Bowdlear, Walter Sorge, 25 Niños, La Colección de Arte Gráfico Mexicano, Jesús Reyes Ferreira, Enrique Bryant, $10^{\mathrm{a}}$ Exposición Anual de los Acuarelistas del Instituto de Arte de México.

Instituto Francés de la América Latina: Guy Mahé, Leonel Maciel, Víctor Muñoz, Alejandro Chacón Pineda, Imágenes de Pastrana, Díaz Cañedo, Richard R. Benda, Firzia, Teódulo Rómulo, Guillermo Meza.

Instituto Anglo-Mexicano de Cultura, A. C.: Nicolás Moreno, Rodolfo Nieto, Fiona Alexander.

Instituto Cultural Mexicano Israelí: Gustavo Arias Murueta, Exposición colectiva gráfica, Pablo Weitz y Arturo Pastrana, Anatoli Koplan, Pedro Meyer, Saúl Borisov.

Instituto Cultural Hispano-Mexicano: Ruby Aránguiz, Exposición colectiva.

OTROS CENTROS CULTURALES

Alianza Francesa: Eidos 7, Benjamín.

Museo Pedagógico Nacional SEP: Eduardo Cohen.

Escuela de Diseño y Artesanías, SEP : Exposición 1970-1971.

Universidad de las Américas: Erasto Cortés Juárez.

Instituto de Arte de México: Jesús Tello, León Plancarte Silva, La mujer en la plástica, Rodolfa Aguirre Tinoco, Alaniz, Pensamiento mágico.

Centro Deportivo Israelita: Donn Hart, Simón Rubinstein, Marco Chilet, Tzipora Ronen, Moisés Nifco, Joseph Nadel, Grupo espiral, Helen Bickhan.

Las Galerías particulares de la ciudad de México presentaron una serie de exposiciones de calidad.

Galería de Arte Mexicano: Alfredo Castañeda, Kishio Murata, Pedro Coronel, Enrique Echeverría, Emilio Ortiz, Olga Costa, Joy Laville, Carlos Mérida.

Galería de Arte Mexicano-Florencia: Le Corbusier, Mario Rangel, Pedro Coronel, Edmundo Aquino, Enrique Zavala, Xavier Guerrero, Guillermo Terminel, Lauro López.

Galcría Misrachi: Rufino Tamayo, James Pinto, Héctor Cruz, Jean David. 
Galcria Juan Martin: Szyszlo, Vicente Rojo, Fernando García Ponce, 1 x 3, Manucl Felguérez.

Galcria Pecanins: Sebastián-Mallard, Tomás Parra, Myra Landau, Salvador Brn, J.conel Góngora, Amold Belkin, Juan Bañuel, Nissen.

Centro Cultural Filla Olumpica: Tulio Avila, Grupo Ultra.

Galcrias "Mor-Kup": Wäldemar Siölander, Krupskaia y René Alis, Silvia H. González, Kaethe Kollwitz, Lilo Leoni, Baruj Salinas, Pilar Castañeda, Sofía Bassi, Antonio Henrique Amaral, Mathias Gocritz.

Galcria "Edvard Munch": Rosario Herrán, Gerardo Cantú, Elsa Barragán, Carlos Itrado, 170 miniaturas, Kubli 71, Actoeromanías, El grabado de hoy, Gay Sclianlert y J. R. C. Manto, Fred de Keijzer, Seres y Hechos, Tosé Hernández Delgadi11o, Marcos Huerta, Gonzalo Cienfuegos.

Galeria Aril: Bárbara Locketz, Jody McGratlı, Heriberto Juárez, Kurt Larisch. lesús Tellosa, Enilio Ortiz, Olga Dondé, Robert Kaupelis, Martin Battersby, Armando Villagrán, Manuel Manilla, Antonio Suárez, Gastón González César, Feliciano Léjar, Francisco Toledo, Elvira Gascón.

Plástica de México: Colectiva, El paisaje, la figura, 50 pequeñas obras, Fernando Vilchis, Leticia Tarragó, Trinidad Osorio, Venta de Navidad, Gustavo Montoya.

Galcría Rosano: Emma Limón, Edgardo Coghlan, Exposición colectiva de pinturas y grabados, Rodolfo Reyes Treviño, Exposición colectiva.

Galeria Gandhi: Exposición colectiva, Arte irracional.

Galeria Kalisteia: Guillermo Barclay.

Galería Escudcro: Camps Rivera.

Galerias San Francisco: 4 pintores.

Galería de Arte: José Maya.

Galería Central de Arte Moderno: Francisco García Simona.

\section{HOTELES (GALERÍAS)}

Hotel Continental Hilton: Salón la Joya: Gabriela Ma. de los Angeles Cajigas.

Hotel María Isabcl: Galería arte de Coleccionistas: Elsa Vázquez.

Hotel Camino Real: Enrique Zavala, Ignacio M. Beteta.

IIotcl El Presidente: Galería lldefonso Aguilar, Yolanda Melo y Jorge Rodríguez.

EXPOSICIONES PARTICULARES

Mansión en Río Lerma y Cuauliténoc: Subasta de Obras de Arte.

Calle de Marsella: Impresiones de Italia.

Modulock, S. A. (Berlín Nún. 30): Francisco Valero. 
Museo Nacional de Artes e Industrias Populares Fideicomiso para cl Fommo do

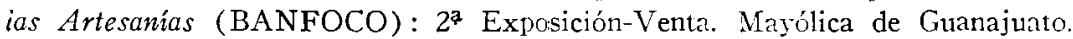

Financiera Comermex, $S$. A.: Zukor.

Sala de Arte Público (Esc. Taller Siqueiros, A. C.) : Alvar Carrillo Gil.

Centro de Artes y Humanidades: Piro-Artesanías de Heber Romo.

Sindicato Mexicano de Electricistas: Exposición pictírica.

Taller de Santo Domingo: Presencia gráfica.

Sindicato N.T. E. : Amador Lugo G.

GALERÍAS EN LOS ESTADOS DE LA REI'ĹBLICA

Galeria Municipal Chapultepec y España (Guadalajara, Jal.): Alberto Gómez Barbosa.

INBA. Gobierno del Edo. de Nuevo León (Monterrej; N. L.) : Amador Lugo.

Galería del Depto. de Turismo de Michoacán (Morelia, Micl.) : Nicolás Moreno.

Galería Municipal F. Ramirez Osorio (Puebla, Pue.) : Erasto Cortés Juárez, Leni de Servín.

Casa de la Cultura, Gobierno de Toluca (Toluca, Méx.): Fernando Caballero, Expo-evento.

Fundación Cultural "Miguel Cabrera" (Oaxaca, Oax.): Edmundo Aquino, Heriberto Juárez, Pilar Castañeda, Teodoro Velazco y José Luis Colín, José Hernández Delgadillo, Adrián Brun y Liborio L. Navarrete, Francisco Moreno Capdevilla, Iavier Arévalo, Leonel Maciel.

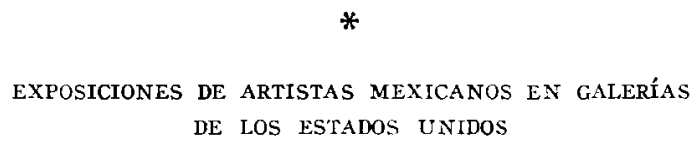

Guleria Bertha Schofer (Nueva York): Feliciano Béjar.

Galería Fine Arts (San Diego, Cal.) : Francisco Zúñiga.

The Emerson Gallery (Encino, Los Angeles, Cal.): Elizabeth Millioud.

The I. F. A. Galleries, Inc. (Washington, D. C.) : Leonardo Nierman.

La Asociación del Museo de Arte (El Paso, Tex.): Leonardo Nierman.

En este catálogo se han incluido algunos textos que aparecen en los catálogos de las exposiciones para salvarlos del olvido, puesto que vienen a ser documentos históricos. También se incluyen los datos biográficos esenciales de los artistas, cuando se encuentran en los catálogos. Esperamos la benevolencia de los interesados, ya 
DOI: http://dx.doi.org/10.22201/iie.18703062e.1972.sup1

que se trata de conservar informaciones que de otra manera sería muy difícil reunir por los historiadores en el futuro; de esta manera pretendemos contribuir a los estudios que se hagan más adelante.

Justino Fernández 


\section{ENERO}

BáRBARA LOCKETz. Exposición de acero inoxidable-plástico, presentada por la Galería de Arte Arvil, Hamburgo 241, del 4 al 23 de enero.

alfredo Castañeda. Exposición de nuevas pinturas y dibujos, presentada por la Galería de Arte Mexicano, Milán 18, del 11 de enero al 6 de febrero.

Catálogo: 1. camino 2. el gordo 3. una llamada telefónica 4. bailable 5. el día del barrendero 6. presagios 7. allá 8. vidente 9. dos arbolitos 10. bruja 11. la fotografía 12. la vieja 13. los de la ventana 14. la mirada del hombre de la corbata 15. los últimos de la rosita 16. la segunda reunión 17. manifestación 18. cuatro y el tiempo 19. toque de alerta 20. fruta 21. identificación 22. escultor 23. cabeza 24. rostro sonriente 25. con reservas 26. el hombre de la viga. 27. hombre descansando 28. sabiduria secular 29. robachicos 30. Soléa 31. rostro amigo 32. al despertar 33. lunático 34. los murmuradores 35. nada menos que todo un viejo 36. testigo $N^{P} 1$ 37. el hombre de la cajita 38. predicador 39. comprometidos 40. hombre ausente 41. la familia del fotógrafo 42. mensajero 43. el creyente 44. fenomenólogo 45. el diseño 46. mujer con margaritas 47. presencias 48. la marca 49. jugador de cartas 50. cosas.

Rosario herRan. Exposición (1946-1969), presentada por la Galería de Arte Edvard Munch, Paseo de la Reforma 489, el 11 de enero.

WäLdEMAR SJÖLANDER. Exposición de pinturas y esculturas, presentada por las Galerías Mer-Kup, Molière $\mathrm{N}^{\circ} 328-\mathrm{C}$, el 12 de enero.

GUY MAHÉ. Exposición de pintura reciente, presentada por el Instituto Francés de América Latina, Nazas 43, del 13 al 29 de enero.

PINTORES CONTEM PORÁNEOS holandeses. Exposición presentada por el Instituto Nacional de Bellas Artes, Embajada del Reino de los Países Bajos, Museo de Arte Moderno, Chapultepec, Galería de Exposiciones Temporales, el 14 de enero.

Una exposición de 33 pinturas y 33 gouaches de artistas contemporáneos holandeses será inaugurada el jueves 14 de enero a las 19:30 horas en la Galería de Exposiciones Temporales del Museo de Arte Moderno en Chapultepec por el Embajador del Reino de los Países Bajos en México, licenciado Berend J. Slingenberg.

La exposición, reunida bajo la responsabilidad del Ministro holandés de Cultura, incluye obras de 32 artistas holandeses representantes de varios grupos artísticos acti- 
vos en los Países Bajos, tales como el vitalista grupo Cobra y, entre otras, las dos escuelas contrastantes de Amsterdam y de La Haya.

La exhibición, primera exposición internacional presentada en el famoso Museo de Arte Moderno de Chapultepec en 1971, puede ser considerada como una continuación a la exposición de 40 dibujos de artistas contemporáneos holandeses que abrió la serie de importantes exposiciones extranjeras en el Museo de Arte Moderno en 1970.

Pintura moderna holandesa: Para los Países Bajos, la Segunda Guerra Mundial fue el primer conflicto en que se vio totalmente envuelto el país. En muchas formas, los años de ocupación enemiga abrieron una brecha en el tiempo. Después de la liberación, se presentó una generación de artistas nacidos durante los veintes, libres de las tradiciones de la pre-guerra y empapados de una elemental vitalidad. Esta vitalidad se inició con un juvenil lirismo que pucde cucontrarse en los gouaches menos conocidos de Karel Appel y Corneille. Durante los cincuentas, sin embargo, este lirismo o se hizo más exhuberante o volvió la cara con dureza hacia todo lo que pudiera amenazar la libertad recién encontrada. Los pintores más prominentes entre los vitalistas pertenecían al grupo "Cobra". Están representados en esta colección por Constant, Lucebert y Rooskens. Sin embargo, "Cobra" era la expresión de un cambio extenso y permanente en el clima artístico. Como resultado, la obra de varios de los demás artistas aquí representados tales como Frieda Hunziker, Lataster y Van Soest delata tendencias similares. Los dos últimos, igual que Defesche, nacieron en Limburgo, la provincia más meridional de los Paises Bajos y una que, como Amsterdam, produjo una cosecha particularmente abundante de vitalistas.

El único cuadro pintado antes de la guerra en esta exhibición es obra de Job Hansen (cat. $\mathrm{n}^{\circ}$ 11) y no contrasta en forma tan marcada con las demás obras como podríamos esperar después de haber leído lo anterior. Y es que, después de todo, Hansen - junto con el impresor y artista gráfico H. N. Werınan, con quien formó parte del grupo "Ploeg" en Groningen- era una especie de lobo solitario entre los pintores de la pre-guerra.

Para algunos pintores holandeses tales como Jan van Heel, Willem Hussem y Oepts, Francia había sido su segundo hogar, aún antes de 1940. Una vez que volvicron a abrirse las fronteras, reanudaron su contacto íntimo conl la pintura francesa. Y en la misma forma que París representa el concepto universal de la pintura culta, La Haya encarnaba esa idea en los Países Bajos, aún mucho tiempo después de haberse esfumado las glorias de la Escuela de La Haya. Fue la ciudad donde, además de Van Heel y Husem, el dedicado Jacob Nanninga trabajaba, ensoñadoramente absorto en su pintura.

La gran diferencia entre las pinturas de Amsterdam y de La Haya es también notable al comparar la obra de Sierhuis (Amsterdam) con la de Bouthoorn (La Haya). Kees van Bohemen, sin embargo, prueba la excepción a esta regla al separarse de ella y aplicar una cierta impetuosidad comúnmente identificada con el clima de Amsterdam.

Una figura un tanto aislada en Amsterdam es Jaap Wagemaker, quien en 1966 recibió el Premia del Estado de los Países Bajos por su pintura, en la cual incorporó diferentes medios. 
govaches Holandeses. En la pintura holandesa de la post-guerra, el gouache ha adquirido mayor prominencia que nunca antes. Varios artistas llegan al extremo de imprimir el carácter del gouache a sus pinturas. Otros utilizan la técnica del gouache exclusivamente, o bien es este el medio con el cual consiguen sus mejores resultados. Aparentemente el gouache - aparte de otras técnicas, completamente nuevases tan significativo de nuestro tiempo como lo que el pastel al siglo dieciocho.

La capa cobertora de pintura de agua produce una superficie opaca. El gouache permite una excelente combinación con el crayón, la arena y otros medios para conseguir una armonía verdaderamente "sensitiva". $Y$ esto no es sólo un asunto estético: las graduaciones en estructura y la diversidacl de materiales colorantes corresponden a sutiles matices de sentimiento.

Existe una marcada diferencia relativa de sensibilidad en la selección de las obras aquí expuestas. Hay aquellas que expresan alegría o dolor, exaltación o enajenamiento, impersonalidad a soledad; pero ninguna de ellas está exclusivamente cominada por uno solo de estos sentimientos.

En mayor o menor grado, todas reflejan la variedad de impulsos y humores que determinan la actitud humana hacia la vida en este siglo.

Dolf Welling

DONN HART. Exposición de pinturas, presentada por el Centro Deportivo Israelita, Galerías C. D. I, Manuel Ávila Camacho $\mathrm{N}^{9} 620$, el 14 de enero.

Hace un año conocí por primera vez la pintura de Donn Earl Hart. Su contenido liumano, tanto por su temática como por su forma, me complació, y así se lo manifesté claramente. Posteriormente tuve la oportunidad de seguir su proceso en las vías del arte. El progreso que encontré en tal desarrollo fue para mí, patente en extremo. El sentido dramático de su obra como la originalidad del mismo se había acentuado evidentemente. Hablando en términos generales, puedo decir que su obra ya realizada en México, surgió ante mí como una demostración de que su desarro1lo posterior, con un profesionalismo indiscutible, tomaría sus proporciones de gran pintor. No se trata de un artista que rehuye el contenido humano y la fuerza profesional con medios subjetivistas, sino de un creador de expresiones formales y una voz humana en extremo. No juega con la pintura, no se pierde en emociones transitorias e incompletas, sino que va derecho a un arte de composición tanto por su cspíritu como por la estructura de su forma. Es ya un gran artista de la plástica y, no me cabe la menor duda, en estos precisos momentos está avanzando con pasos firmes a una creación cada vez más trascendente. En suna, el arte del señor Hart tiene cuerpo vigoroso y gran espíritu.

Sigüenza

NiCOLÁs moReno (retrospectiva), ALberto DE LA VEGA (bronces). Exposiciones de óleos y encáusticos, presentada por el Instituto Anglo-Mexicano de Cultura, A. C., Maestro Antonio Caso 127, el 18 de enero. 
Datos biográficos de los artistas: Nicolás Moreno, nació en México, D. F. en 1925. Estudió en la Escuela Nacional de Artes Plásticas de la UNAM, de 1941 a 1945 y fue profesor de enseñanzas artísticas en el Instituto Nacional de Bellas Artes de 1946 a 1963. De 1951 a 1970 ha sido profesor por oposición en la Cátedra de Paisaje en la E. N. A. P. de la UNAM. Alberto de la Vega, nació en Coxcatlán, Puebla en 1923 y murió en México, D. F. en 1969.

NACHo hernández. Exposición de óleos y acrílicos, presentada por la Galería José Ma. Velasco, INBA/S. E. P., Peralvillo 55, el 22 de enero.

Catálogo: 1. mujer $N^{0} 1$ 2. mujer $N^{0} 2$ 3. $R-e-y-n-a$ 4. entrelazados 5. góndolas 6. paisaje 7. paisaje $I I$ 8. guitarras $N^{Q} 1$ 9. guitarras $N^{Q} 2$ 10. cabeza 11. ventanas 12. eclipse 13. tiempo 14. mujer con turbante 15. gato 16. pareja 17. composición 18. Cristo 19. muros 20. escalera 21. Leda y el cisne 22. composición.

gabriela maría de los ÁNgeles Cajigas. (Homenaje Heinrich Kley) Exposición de dibujo, presentada por el Hotel Continental Hilton Salón La Joya, el 21 de enero.

Mujer en la que el talento es simultáneo a la belleza, Gabriela María de los Ángeles Cajigas presenta quince dibujos de su producción reciente; quince expresiones de lo que ella define como "concepto torturado de la existencia vital". La angustia, la inconformidad, quizá también el miedo, son los signos que le dan carácter al quehacer artístico de esta joven que desertó del trabajo legal -es abogado- para iniciarse, hace siete años en la aventura de la creación. Las obras de Gabriela consiguen lo que su autora se ha propuesto: comunicar lo incomunicable, trascenderse, involucrar en su misterio y en su transparencia, a quien las contempla. Misterio y transparencia que oculta, al revelarlo, el sentido dramático, "torturado", de estos dibujos en los que el chapopote y los materiales vinílicos sirven para expresar algo más profundo, más cerrado, mucho más denso, de lo que declaran.

LuIs SPOTA

GERARDO CANTÚ. Exposición "el circo y atras maromas", presentada por la Galería Edvard Munch, Paseo de la Reforma 489, del 25 de enero al 8 de febrero.

LEÓN PLANCARTE silva (1915-1969). Exposición de dibujos y grabados, presentada por el Instituto de Arte de México, Puebla 141, del 26 de enero al 15 de febrero.

ROSTROS: hOMENAJE A BERNICE KOLKo. Exposición con selección de obras de la artista fotógrafa, presentada por el Departamento del Distrito Federal, Dirección General de Acción Cultural y Social, Galerías de la Ciudad de México, Alameda Central, Sala Juárez, del 29 de enero al 28 de febrero.

Un busto y dos retratos que en honor de Bernice Kolko realizaron: Dina Frumin, Lupe Sierra, Elizabeth Avila.

Bernice Kolko ha muerto. Solitaria... entre recuerdos... Su amor a la vida - su gran amor a los seres humanos, a las cosas realizadas por el hombre- su gran amor a las cosas bellas, la caracterizó siempre. 
Enjoyada con cobre y hierro - joyas del arte popular de todo el mundo- majestuosa, Bernice se acercaba a la gran fuente de inspiración que fueron para ella los seres humanos. Provista de su cámara fotográfica, dejó grabadas placas que muestran el carácter de los hombres y los pueblos. Su mejores maestros - según ella confesaba a quien quisiera escuchar- fueron los pintores clásicos. Y la mejor aliada a su arte fue la vida misma.

Bernice Kolko ha dejado una obra extraordinaria, interesante para los antropólogos, los sociólogos, los humanistas, los pintores. Cada fotografía suya, es una obra maestra.

Era judía polaca, nacionalizada norteamericana, pero sus quince años de "turista" en México, la convirtieron en la gran mexicana que tanto amó este país.

Sencilla, humana, sobrevivió a las dos guerras mundiales. En Nueva York, cuando joven, vendió en la calle poemas para poder comer. Después, con una modesta pensión, instaló su departamento permanente en las calles de Progreso y allí la encontró la muerte.

Bernice Kolko, en vida, expuso dos veces en estas Galerías de la Ciudad de México, la primera durante la Olimpiada Cultural de 1968, en la Alameda Central y la segunda sus "Rostros de México", en el Centro Social Popular "Leandro Valle" de la Colonia Agrícola Oriental. Ahora, las autoridades del Departamento del Distrito Federal a través de la Dirección de Acción Cultural y Social, le rinden homenaje póstumo. Descanse en paz.

LE CoRbusIer. Exposición de grabados, presentada por la Galería de Arte MexicanoFlorencia, Florencia 35, el 29 de enero.

Catálogo: 1. unité 5, aguafuerte color, $57 \times 45 \mathrm{~cm} .1953$ 2. unité $6,57 \times 45 \mathrm{~cm}$ 1953, aguafuerte color 3. unité $7,57 \times 45 \mathrm{~cm}$. 1953, aguafuerte color 4. unité 15, $57 \times 54 \mathrm{~cm}$. 1953, aguafuerte color 5. unité $12,57 \times 45 \mathrm{~cm}$. 1953, agquafuerte, blanco y negro 6 . unité $10,57 \times 45 \mathrm{~cm}$. 1953, aguafuerte blanco y negro 7 . unité $657 \times 45 \mathrm{~cm}$. 1953, aguafuerte blanco y negro 8. unité $13,57 \times 45 \mathrm{~cm}$. 1953 , aguafuerte blanco y negro 9. unité $2,57 \times 45 \mathrm{~cm}$. 1953, aguafuerte blanco y negro 10. unité $3,57 \times 45 \mathrm{~cm}$., 1953 , aguafuerte blanco y negro 11 . portrait, $76 \times 64 \mathrm{~cm}$. litografía 12. taraux, $110 \times 64 \mathrm{~cm}$. litografía 13. Femme a la main levée, $108 \times 67 \mathrm{~cm}$. litografía 14. totem, $73 \times 81 \mathrm{~cm}$. litografía 15. la main ouverte, $65 \times 50 \mathrm{~cm}$. litografía 16 . masques, $52 \times 76 \mathrm{~cm}$. litografía 17. naissance $d u$ Minotaure, $57 \times 76 \mathrm{~cm}$. aguafuerte blanco y negro 18. composition, $76 \mathrm{x}$ $57 \mathrm{~cm}$. aguafuerte 19. naissance du Minotaure, $57 \times 76 \mathrm{~cm}$. aguafuerte blanco y negro.

Juan o'gorman. Exposición presentada por el Salón de la Plástica Mexicana,

INBA/S. E. P./Havre No 7, del 29 de enero al 20 de febrero.

Catálogo: I, proyecto de los murales para la Ywmja de Pittsburgh, Pa., E. U. A. $\begin{array}{llll}\text { 1. el fascismo y la guerra, } 1939 \text {, dibujo a lápiz, } 41 \times 145 & \text { 2. la sociedad sin clases }\end{array}$ y la Paz, 1939, dibujo a lápiz, $41 \times 145.3$ 3. capitalismo revolucionario, $1939,41 \times$ 161, dibujo a lápiz 4. capitalímo decadente, $1939,41 \times 161$, dibujo a lápiz 5. los indios Iroquois, 1939, 41 x 36, dibujo a lápiz 6. la caridad, 1939, $41 \times 36.5$, dibujo a lápiz 7. la anarquía, 1939, $41 \times 36$, dibujo a lápiz 8. la filantropía, 1939, $40 \mathrm{x}$ 49, dibujo a lápiz 9. la huelga de Homestead, $1939,41 \times 50$, dibujo a lápiz 10 . Ios transformadores de la sociedad, 1939, $44 \times 65$, dibujo a lápiz 11. la evicción, 41 x 36, dibujo a lápiz II. Proyecto mural Revolución de 1910-14. Retablo de Fran- 
cisco I. Madero. Museo de Historia, Castillo de Chapultepec 12. composición total del mural, 1968, $58 \times 66$, dibujo a lápiz III. Proyectos otros murales 13. la salud y la enfermedad, 1949 (Hospital Infantil, ciudad de México, 1er. croquis a lápiz $25 \times 87$ ) 14. la filosofía y la ciencia, $1948,28 \times 56$, dibujo a lápiz, ler. craquis 15. la filosofía y la ciencia, 1948, $68.5 \times 121$, dibujo a tinta 16 . paisaje de Mírico, 1965, $60.5 \times 133.5$ dibujo a lápiz IV. Proyecto murales Puerto Aéreo de 1a ciutad de México, Antiguo edificio 17. la aviación irreal, 1937, 54 x 180, dibujo a lápiz 18. historia de la aviación, 1937, $54 \times 182$, dibujo a lápiz V. Proyecto mural en la biblioteca "Gertrudis Bocanegra", Pátzcuaro, Mich. 19. historia de Michoacán, 1940-41, $170 \times 153$, dibujo a lápiz VI. Proyecto mural del Banco Internacional, $S$. A., Paseo de la Reforma, Ciudad de México 20. el crédito transforma a .1J ćrico, 1963-64, $43 \times 2.38$, dibujo a lápiz 21. dibujo a tamaño natural del Mural de la Sala de la Revolución / Retablo de Francisco I. Madero, Museo de Historia, Castillo de Chapultepec, 1968, $410 \times 650$ IX. Proyecto Mosaicos de la Secrctaria de Comunicaciones y Obras Públicas, México, D. F. 22, muro norte, $19: 3,75 \times 45$, dibujo a lápiz 23. muro norte, $1953,79 \times 53$, dibujo a lápiz 24 . cntrada al Vestíbulo, 1953, fachada norte, $29 \times 81$, dibujo a lápiz 25 . plafón del vestíbulo norte, 1953, $20 \times 75$, dibujo a lápiz 26. sección " $A$ " del muro al ponientc. $1953,81 \times 39$, dibujo a lápiz 27 . sección " $A$ " del muro al oriente, $1953,81 \times 27$, dibujo a lápiz 28. sección " $B$ " del mura al Oriente, $1953,81 \times 45$, dibujo a lápiz 29. sección " $B$ " del muro al Poniente, 1953, $81 \times 45$, dibujo a lápiz XII. Proyecto Mosatico de la posada de la Misión, Taxco, Gro. 30. Homenaje a Cuauhtémoc, $1955,46 \times 115$, dibujo a lápiz XIII. Proyecto Mosaico parque de San Cristóbal, Santiago de Chile 31. fraternidad de los pueblos de México y Chile, 1964, 62 x 157, dibujo a lápiz, XIV. Proyecto Mosaicos en la Casa de Av. San Jerónimo 162, San Angel, D. F. 32. Xochipilli, 1950, $45 \times 53$, dibujo al lápiz 33. Quctzalcóatl, 1950. $44 \times 51$, dibujo a lápiz 34. fertilidad, 1950, $72 \times 50$, dibujo a lápiz 35. águila. agia y fuego, $1950,40 \times 57.5$, dibujo a lápiz.

EDMuxDo aquino. Exposición de 15 serigrafías, presentada por la Fundación Cultural. Miguel Cabrera, García Vigil 818, Oaxaca, Oax.

Datos biográficos del artista: Edmundo Aquino, nace en Zimatlán de Alvarez, Oaxaca, en 1939. Estudió en la Escuela de Artes Plásticas, México de 1958 a 1962. Maestro en la Escuela Nacional de Artes Plásticas en 1963. Dirigió la Sección de Artes Plásticas, Escuela de Bellas Artes de Oaxaca. (México) de 1964-1967.

FELICIANo BÉJAR. Exposición de magiscopios, presentada por la Galería Bertha Schaefer, 41 East 57th Street, New York, del 5 al 23 de enero, en Estados Unidos.

\section{FEBRFRO}

Colectry. Exposición de grabado, presentada por Plástica de México, Londres 139, del 2 al 27 de febrero.

Nombres de los expositores: Francisco Corzas, Vicente Gandia, Carlos Iurado, Luis Lópc: Loza, Trinidad Osorio, Leticia Tarragó, Gildardo Uribe, Fernando Vilchis, Rafael Z̈epeda.

rostros DEL Mundo. Exposición Homenaje a Bernice Kolko (1905-1970), presentada por el Instituto Nacional de Bellas Artes, Universidad Nacional Autónoma de México, Instituto Nacional de Antropología e Historia, Dirección General de Asuntos Culturales de la Secretaría de Relaciones Exteriores, Dirección General de Ac- 
ción Social y Cultural del Departamento del Distrito Federal, Galería del Palacio de Bellas Artes, Sala Internacional, el 3 de febrero.

IRENe becerriL. Exposición de óleos, presentada por el Departamento del Distrito Federal, Dirección General de Acción Cultural y Social, Galerías de la Ciudad de México, Alameda Central, Sala Hidalgo del 3 al 28 de febrero.

MA. TEResa toral. Exposición de grabados, presentada por el Departamento del Distrito Federal, Dirección General de Acción Cultural y Social, Galerías de la Ciudad de México en el Centro Social Popular "Aquiles Serdán" (Puerto Tampico No 4, esq. con Puerto Guaymas, Ampliación de la Colonia Casas Alemán), del 4 al 28 de febrero.

Mantel gonzález. Exposición presentada por el Departamento del Distrito Federal, Dirección General de Acción Cultural y Social, Galerías de la Ciudad de México, Centro Social Popular Leandro Valle, Av. Sur y Oriente 241, Col. Agrícola Oriental, del 4 al 28 de febrero.

ruIZ vidaurRI. Exposición de Vitroformas presentada por el Departamento del Distrito Federal, Dirección General de Acción Cultural y Social Galerías de la Ciudad de México en el Centro Social Popular José María Pino Suárez, Calzada de la Viga y Guillermo Prieto, Col. Jamaica-Merced, del 6 al 28 de febrero.

artiro ramírez juárez. Exposición de dibujos, serie: el Hombre, presentada por el Departamento del Distrito Federal, Dirección General de Acción Cultural y Social, Galerías de la Ciudad de México, Centro Social Popular, José Ma. Morelos y Pavón, Lago Trasimeno y Lago Erne, Col. Pensil, del 6 al 28 de febrero.

JEsús contreras peÑa. Exposición de monotipos, presentada por la Galeria Chapultepec, INBA, Insurgentes Sur número 11 bis, el 9 de febrero.

colectiva. Exposición de cerámica, Gres de gran Fuego, presentada por el Museo de las Culturas, INAH. S. E. P., Moneda 13, del taller experinental de Alberto Díaz de Cossío, el 9 de febrero.

Nombre de los expositores: Rosa María Aragón, Salvador Magaña, Norio Matsumoto, Akihiko Nagata.

KRTPSKAIA y RENÉ ALIS. Exposición de obras recientes, presentadas por las Galerías Mer-Kup, Molière número 328-C, el 9 de febrero.

LEONEL maciel. Exposición de óleos, presentada por el Instituto Francés de América Latina, Río Nazas 43, del 10 al 26 de febrero.

rlfino tamayo. Exposición de pintura reciente, presentada por la Galería de Arte Misrachi, Génova 20, el 11 de febrero.

Catálogo: 1. personajes en un interior, $95 \times 130 \mathrm{~cm}$. 2. hombre en el espacio, $95 \times$ $130 \mathrm{~cm}$. 3. solitario, $95 \times 130 \mathrm{~cm}$. 4. mujer en un interior, $95 \times 130 \mathrm{~cm} .5$. hombre y mujer, $95 \times 130 \mathrm{~cm} .6$. nnijer, $95 \times 130 \mathrm{~cm}$. 7. tres personajes en rojo, $95 \times 130$ 
cin. 8. tres personajes, $95 \times 130 \mathrm{~cm}$. 9. mujeres en el espacio, $95 \times 130 \mathrm{~cm} .10$ dos personajes en un interior, $95 \times 130 \mathrm{~cm}$. 11 . mujer reflejándose en un espejo, $95 \times 130 \mathrm{~cm} .12$. hombre en verde y azul, $100 \times 81 \mathrm{~cm}$. 13. figuras sobre fondo blanco, $100 \times 81 \mathrm{~cm}$. 14. hombre en rojo, $195 \times 125 \mathrm{~cm}$. 15 . figura cn negro, 81 $\mathrm{x} 100 \mathrm{~cm} .16$. personajes cogidos de la mano, $195 \mathrm{x} 135 \mathrm{~cm} .17$. personajes en el estacio, $195 \times 135 \mathrm{~cm} .18$. hombre sobre fondo amarillo, $50 \times 35 \mathrm{~cm}$.

CLUB FOTOGRÁfico DE MÉxico. Exposición de fotografías, presentada por el Instituto Mexicano Norteamericano de Relaciones Culturales, A. C., Galería Nabor Carrillo, Hanburgo 115, el 12 de febrero.

José chávez moRADo. Exposición de obras presentada por la Dirección General de Acción Cultural y Social, Museo de la Ciudad de México, Pino Suárez 30, el 12 de febrero.

Catáloga: 1. basílica subterránca 2. murallas rotas 3. la mclancólica 4. dos mujeres 5. conversación 6 croto 7 . jucos cósmicos 8 . virgenes prudentes 9 . la máscara del blanco 10. dualidad 11. paisaje arquitectónico 12. semana santa 13. el naranjo 14. cabera bizantina 15. pájaro rojo 16 . gran frutero 17 . bohío nocturno 18 . pictá 19. cargadores de andas 20. lamento por la paloma azul 21. la muerte del poeta 22. flora 23. rostro 24. friterito blanco.

jomy mCGRATH. Exposición presentada por la Galería Arvi1, Hamburgo 241, el 15 de febrero.

ei. univirso de la univfrsidad. Exposición de fotos de Armando Salas Portugal, patrocinalor, Agfa-Gevaert de México, presentada por el Instituto Nacional de Bellas Artes, Consejo Nacional de Turismo, Galerías del Palacio de Bellas Artes, Salas 4 y 5 , el 16 de febrero.

LA MUJik EN LA PLÁstica. Exposición presentada por el Instituto de Arte de México, J'uebla 141, el 17 de febrero.

simón rubinstein. Exposición de dibujos, presentada por el Centro Deportivo Israelita, Galerías C.D. I., Av. Manuel Ávila Camacho 620, el 18 de febrero.

Colectiva 71. Exposición de dibujo, grabado, pintura y escultura, presentada por la Galería José Ma. Velasco, INBA/S. E. P. Peralvillo 55, el 19 de febrero.

Nombre de los expositores: Gerardo Cantú, Gilberto Ramirez, Guillermo Zapfo, Fclipe Castañeda, José Zúniga.

REALIDAL PICTÓRICA DEL ECUADOR. Exposición de artistas contemporáneos, presentada por el Irstituto Nacional de Bellas Artes, Ecuatoriana de Aviación, Casa de la Cultura Ecuatoriana, Embajada del Ecuador en México, Galerías del Palacio de Bellas Artes, Salas 1 y 2, e1 23 de febrero.

AMAdor lugo G. Exposición presentada por el S. N. T.F. Sección 10, Belisario Domínguez 32, el 23 de febrero.

Catálogo: 1. retrato del Ing. Jorge Robledo Juárez, pastel 2. barco encallado, ólco 3. alrededores de Taxco, óleo 4. paisaje urbano, óleo 5, montañas de Taxio I, óleo 
6. montañas de Taxco II, óleo 7. montañas de Taxco $I I I$, óleo 8. montañas de Taxco $\mathrm{IV}$, óleo 9. el Popocatépetl y el Iatacciluatl, óleo 10. Valle de México, óleo 11. cerro del Huizteco $I$, óleo 12. cerro del Huizteco II, óleo 13. los remedios, oleo 14. Valle de Chalco, óleo 15. barcos en Isla Mujeres, óleo 16. nopales y montañas, óleo 17. Cerro del Chiquihuite, óleo 18. laguna de Bakalar, acuarela 19. puesta de sol en Pie de la Cuesta I, acuarela 20. puesta de sol en Pie de la Cuesta II, acuarela 21. poza en Oaxtepec, acuarela 22. rincón cn Oaxaca, acuarela 23. mariposa en vuelo, acrílico 24. explosión en el espacio, acrílico 25. la tormenta, acrílico 26. en el espacio, acrílico 27. el mundo en llamas, acrílico 28. hamacas $I$, acrílico v. tinta 29. hamacas $I I$, acrílico y tinta 30 . cncmeado $I$, acrílico y tinta 31. cncruzado $I I$, acrílico y tinta 32. desde la cima, dibujo 33. hombres empujando una alcantarilla, dibujo.

EIDOS 7. Exposición de fotografías en color, presentada por la Alianza Francesa de México, A. C., Sócrates 156, esquina Homero, del 25 de febrero al 12 de marzo.

Nombre de los expositores: Renć Adouc, J. Adrián Fernández, Ramón Maza, Héctor Rivera, Carlos Canales, Jorge Martinez N. y Salvador Ortiz.

guillermo barclay. Exposición de grabados, presentada por la Galería Kalisteia, Estrasburgo 24, el 26 de febrero.

\section{MARZO}

szyszlo. Exposición presentada por la Galería Juan Martín, Amberes 17, del 2 al 20 de marzo

SILvia H. GoNzÁlez. Exposición de obras recientes, presentada por Artistas de la Plástica Mexicana, Galerías Mer-Kup, Molière número 328-C, el 2 de marzo.

RUBY ARÁNGUIz. Exposición de pinturas, presentadia por el Instituto Cultural Hispano Mexicano, Tabasco 68, del 3 al 18 de marzo.

Datos biográficos del artista: Ruby Aránguiz, de nacionalidad chilena, es Licenciada en Artes Plásticas de la Universidad de Chile. Ha viajado frecuentemente por Europa y Suramérica para conocer las tendencias de la pintura moderna y se ha interesado especialmente por las escuelas impresionista y expresionista. En la Liga de Arte de Nueva York estudió cursos avanzados de color y composición, durante dos años, bajo la dirección del maestro Ben Cunninglam. Actualmente vive en México, estudiando y compenetrándose con el colorido de su ambiente.

Catálogo: 1. pescador 2. procesión 3. botes en el Río Niágara 4. árboles 5. escalera 6. niño en la ventana 7. la calle de Manolo 8. luz en la noche 9. puente 10. la darila del quitasol 11. Marina 12. aurora boreal 13. puerto de Mystic 14. Fascinación 15. tcrtulia 16. curiosidad 17. desmudo 18. el beso 19 la pesca 20. callejón 21. noche 22. trovadora 23. remolcadora de Veracrus 24. capricho en rojo 25 . caminantes.

CAMPS RIVERA y ENRIQUE casas. Exposición de pintura presentada por las Galerías Escudero, Valencia número 20, del 3 al 23 de marzo.

EL. PAISAJE. Exposición colectiva, presentada por la Plástica de México, Londres 139 , el 4 de marzo. 
Nombre de los expositores: José Clemente Orozco, Trinidad Osorio, Luis Nishizauta. Fernando Castro Pachcco, Jorge González Camarcna, Carlos Orozco Romero, Raúl Anguiano, Feliciano Peña, Pablo O’Higgins, Nicolás Moreno, Eliana Menassé, Héctor Cruz, Héctor Ayala, Froylán Ojeda.

redro friedebera. Exposición presentada por la Galería de Arte Misrachi, Génova 20 , el 4 de marzo.

Catálogo: 1. la infancia de Confusio 2. masturbación colectiva de unos relojeros persas 3. medusa asustada 4. la venus de polanco 5. quince sombreros para dieciseis ninfómanas 6 . excesiva corbatomanía de la baronesa flagelación angustiosa 7 . los cisnes sudan sangre y semen 8. los dandys en los Andes 9. babosa Babilonia banal 10. sirve el ciervo simplemente 11. mermelada de zebra 12. toronja caliente 13 . once cajas de chocolates envenenados 14 . la momia dulce 15. teosofista desobediente. 16. los calcetines de Mozart 17. homenaje a Humnel 18. homenaxe a las esfinxcs Franx Lixt 19. cementerio de sirenas serenidad cirenaica 20. tapiz ecuestre 21 . atrévete arcabuz 22. mueblería ornitológica 23. pagodas veterinarias 24. comprendiendo Mu 25. te lo he dicho mil ieces.

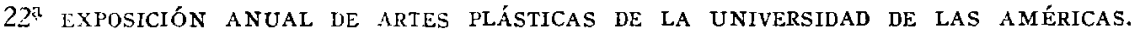
Presentada por el Instituto Mexicano Norteamericano de Relaciones Culturales, A. C., Sala Nabor Carrillo, Hamburgo 115, el 5 de marzo.

Pintura: a) óleo, plástico, encáustica, collage, etcétera, $b$ ) acuarela, temple, gouache, etcétera. Artes Gráficas: grabados en metal, linóleo y madera; monotipo, litografía y serigrafía. Dibujos: lápiz, tinta, crayón, conté, punto de plata, carbón, pastel, etcétera. Fotografía. Escultura: madera, metales, piedra, terracotta, yeso, etcétera.

PER anderson. Exposición de dibujos, presentada por la Escuela Nacional de Artes Plásticas, Sala de Exposiciones, Academia 22, el 5 de marzo.

herinerto juÁrez. Exposición de esculturas, presentada por la Galería Arvil, Hamburgo número 241 , del 8 al 27 de marzo.

valetta. Exposición de 21 óleos, presentada por el Museo de las Culturas, INAH, S. E. P. Moneda 13, el 9 de marzo.

Catálogo: 1. mirando 2. antorcha 3. movimiento (nocturno) 4. noche verde 5. aurora en Ianitzio 6. torito con gigantes 7. procesión 8. en honor de la Virgen 9 . el indio y el caballero 10. luces coloradas 11. danza de gigantes 12. luna llena 13. disfraz alegre 14. linternas de color 15. magia 16. alegria mística 17. la flauta encantada 18. la paloma 19. las velas 20 . noche buena 21 . ave celestial.

EI.SA barRagín. Exposición presagios, presentada por la Galería Edvard Munch, Paseo de la Reforma 489-A, del 9 al 22 de marzo.

PRESENCIA GRÁfICA. Exposición presentada en el II Aniversario del Taller de Grabado de Molino de Santo Domingo, Calle de Santo Domingo número 14, el 10 de marzo. 
Taller de Bustos, Casa Estampa, Centro Experimental de Arte Gráfico, Equipo siete, Taller de la Gráfica Popular, Taller Libre de Grabado de Mario Reyes, Sociedad Mexicana de Grabadores, Taller de Grabado de la Universidad de Guanajuato.

Alejandro Creel. Exposición de dibujos, presntada por la Galería Chapultepec, IN $\mathrm{BA}$, Insurgentes Sur número 11-bis, el 10 de marzo.

Neftalí moreno aparicio. Exposición de obras presentadas por la Galería Chapultepec, INBA, Insurgentes Sur número 11-bis, el 10 de inarzo.

víctor muÑoz. Exposición de acrílicos, presentada por el Instituto Francés de América Latina, Nazas 43 , el 10 de marzo.

JEsús tello, JUlio martínez SAUcedo. Exposición pictórica, presentada por el Instituto de Arte de México, Puebla 141, el 12 de marzo.

sebastín-maldard. Exposición presentada por la Galería Pecanins, Hamburgo 103, el 12 de marzo.

kishio murata. Exposición de pinturas, presentada por la Galería de Arte Mexicano, Milán 18 , el 15 de marzo.

Catálogo: 1. el mar del Sur 2. camino a la Paz 3. colina de arena blanca 4. las flores de la nieve 5. teatro Kabuki 6. saludos a la lina 7. niebla verde 8. la lus del sol de Mayo en el Japón 9. playa matutina 10. Nikko en verde 11. fiesta de Kyoto 12. montaña en invierno en el Japón 13. canción del mar 14. flor en el templo del Japón 15. conversación entre el mar y la colina 16. la sombra de la luna 17. rocio matutino 18. mañana de mayo en el Japón 19. playa y cielo 20. palma y lago 21. tierra madre 22. polen verde 23. primavera en Kyoto 24. nieve matutina 25. un día en jardin Japonés 26. brisa del Oriente 27. palabra infantil 28. la cadencia de la flecha del bambú a la luz de la luna 29. pareia en la playa 30. poema de Otoño en el Japón 31. nieve en la noche.

EXPOSICIÓN DE LIBRos BRITÁNICOS. Presentada por la Universidad Nacional Autúnoma de México, y la Librería Anglo-Americana, Facultad de Química, Ciudad Universitaria, el 15 de marzo.

SAúl borisov. Exposición de Tapicería presentada por el Instituto Cultural Mexicano Israelí, A. C. Rio Tiber $\mathrm{N}^{0} 12$, del 16 al 30 de marzo.

Datos biográficos del artista: nació en Rusia.

mario Rangel. Exposición de Oleos y Acuarelas recientes, presentada por la Galería de Arte Mexicano-Florencia, Florencia 35, el 17 de marzo.

Catálogo: 1. imagen del tiempo 2. cuidando al futuro 3. descubrimiento tardio 4. materializando temores 5. cambio parcial 6. tiempo sin limites 7. estudiando las causas y los efectos 8. ciclo final 9. el domador 10. caprichos de mi naturaleza 11. los limites de lo imprevisto 12. todo ticne an propósito 13. teoría no comprobada 14. un viejo modelo del universo 15. naturaleza muerta a la intemperic 16. el biombo 17. pescador de perlas 18. es posible que nunca 19. el filósofo 20. 
los introvertidos 21. la infancia de la bruja 22. al origen de las comparaciones 23. el sueño del pescidor 24. un orden diverso 25. la manifestación de otras leyes 26. el senutuclo.

BEN JAMÍn. Exposición de ohrás cinéticas, presentada por la Galería de la Ailanza Francesa, Sócrates 156 , del 18 de marzo al 16 de abril.

erasto cortés juÁrez. Exposición Honenaje, presentada por el Salón de la Plástica Mexicana, INBA/S.E.P./Haure $\mathbb{N}^{+9} 7$, tle] 19 de marzo al 8 de abril.

Datos biográficos del artista: Erasto Cortés Juárez, nació el 26 de agosto de 1900 en Tepeacn, Estado de Puebla. Ingresó a la Academia de San Carlos (Escuela Naciolaal de Artes Plásticas) el año de 1916. En 1922 estudió como su último año en la Escuela de Pintura al Aire Libre, en Goyoacán, D. F. En 1923 ingresa como maestro re dihujo en las escuelas primarias dependientes de la Secretaría de Eclucación Pítblica. En 1946 naestro titular de dibujo de $1^{\circ}$ y $2^{\circ}$ años, en la Escuela Nacional de Ares Plásticas hasta 1956 que fue cuando se pensionó. De 1947 a 1956 maestro de diinjo en la Escuela de Pintura y Escultura, dependiente del Instituto Nacional de: B心llas Artes. Fn 1948 comienza a grabar, considerado como autodidacta. En 1950 se edita st plaqueta "Fisononía de Animales", con 40 grabados originales y respeclivos textos que él mismo escribió. En 1951 su segunda obra titulada "El grabado contemunnáneo". En 1960 su tercera obra titulada "Héroes de lá Patria", con 36 textos biográficos y respectivas efigies en grabalo. Esta obra se la editó la Liniversidad Nacional Autónona de México. Tín 1967 se editó en San Miguel de Allende, el "Calenclario Histórico Guanajuatense", Recopilación de 1,000 fichas y 20 grabados ilnstrativos. Prepara actualmente ha "Historia del Grabaclo en México". Ha escrito numerosus artículos sobre artes jlásticas y asuntos de Historia de México. Colaboraciones en diversas revistas y periódicos tanto de la capital como de la provincia. Findador y subdirector técnico del Centro Cultural "Ignacio Ramírez", ubicado en San Mignel de Allende, Estado de Guanajuato. Creć varios talleres de Artes Pláslicas, En la nisma pollación guanajuatense presidente de la Corresponsalía del Seminario de Cultura Mexicana. Organizó exposiciones de artes plásticas, un Jardín lel Arte, un Cine-Club y diversos conciertos y conferencias. Ha participado en numerusa exposiciones colectivas de grabado y varias individuales, tanto en la ciuclad de Mézico, como en los Estaldos y en el extrinjero. El Museo de Arte Moderno de Nuea York, el Instituto Nacional de Bellas Artes y la Sociedad de Grabadores Suizos, licnun en sus colecciones varios de sus grabados. A partir de 1951 miembro actiro de la Sociedad Mexicana de Grahadores. De 1951 a 1933 miembro activo del TaHer de Gráfica Popular. A grartir de 1967 miembro activo de la Asociación Mexicana 1c Críticos de Arte De 1954 a 1960 micmbro activo del Primer Núcleo de Grabalores de Puebla. A partir de 1970 miembro tilular y de número de la Academia de Artes. Fin coculbre de 1970 se llevo a efecto en la Sala Verde del Palacio de Bellas Artes su exposicion retrospectiva de srabado, con motivo del acto recepcional como miembro de la citada Acadenia.

Catálogo: Animales: 1 al 7 tintas y grabados en linóleo, 9 al 19 tintas y gralbados en linbleo Otros teinas: 20-21 y 22, tintas Maderis de pie diversos temas $31-33-34-$ 
35-37-38-39 y 43. Linóleos diversos temas: 8-23-25 26272829303236404042 al 60. Artistas 61 al 69, linóleos. Hombres ilustres 70 al 98, linóleos. Músicos 99 al 102. Litografía 24.

CARLos juRnno. Exposición de serigrafías, presentada por la Galería Edvard Muncl, Paseo de la Reforma 489, el 22 de marzo.

20 artistas italianos. Exposición presentada por el Institulo Nacional de Bellas Artes, bajo el patrocinio de la Embajada de Italia, Galería de Expositores Temporales del Museo de Arte Moderno, el 25 de marzo.

Afuntes para veinte artistas italianos: Como toda antología que no tengin intenciones ni dimensiones históricas, y a la cual no se le permita una perspectiva suficiente rara un juicio despojado al máximo de interferencias de gusto o de una momentánea jrojensión estética, así también una colectiva como ésta, linitada a pocos nombres y encerrada en un arco temporal muy breve en lo tocante, por ejemplo, a la feclia de las obras, se reciente inevitablemente de posiciones personales, de convicciones críticas particulares, por lo que debe considerarse parcial y-en cierto modo- tendenciosa. Sin emhargo, aun con estas premisas obligadas y con la conciencia de que otros críticos habrían dado quizás un planteamiento distinto al discurso sustentado por la presente selección, a mí me parece que los veinte artistas elegidos para esta exposición indican de modo muy exacto la situación del arte figurativo italiano en este momento. Y no porque estos artistas (evidentemente, junto con otros de la misma $n$ de las mismas generaciones) figuren loy en día entre los más activos y represcntativos de un cierto esfuerzo de investigaciones completanente nuevas o rejentinas ch un contexto cultural tal vez distinto. Fl problema no es de novedad ni de excentricidad. Fs cierto que ellos se mueven siguiendo linens avanzadas y circunstanciadas, con convicciones y rechazos muy netos y personalcs, pero no se trata de tenlencias casurlcs o derivadas, en muchos casos improvistas sobre la base de sugestiones trumsitorias. Desde un cierto punto de vista - un punto de vista que, estoy seguro, podrá parecer a muchos incluso discutible e impropio- 110 constituyen ni siquiera un aspecto, por decirlo así, de vauguardia cu el arte italiano. En efecto, sus elecciones y sus logros están dados, aunçue cn distinta medida, por nun inteusidad de experiencias coherentes y profundas que se remontan en algunos casos a los primeros años de la postencra, emergen de un hinterland cultural denso y variado, y por cuanto reconocibles cn su madurez y autonomía expresivas se enlizanı con una tradición (tradición discutida, renovadi, vivida, como es justo) indudable e inconfundible. Se trata, pues, de artistas ciemplares, significativos, que toravía podrán dar sorpresas, avanzar sobre 111a senda establecida o bien trastornar c1l un modo incsperado sus actuales posturas, pero que fuera de toda duda han alcanzado en s11 historia individual $11 n$ pinto fijo, madiro y juzgałle, y que subrayan con su obra un rigor que no es 11n11ca frialdad, nma racionalidad que no es ausencia de pasión sino más bicn dominio del dato cmotivo $1 m$ equilibrio estilistico que no es juego hábil e indiferente, sino índice de conciencia ¿lc nitidez comunicativa inclusive en aruellos casos cn que el ansia de la búsqueda, la impacioncia creativa, acicatean con mayor violencia. Sería difícil (y de no serlo serí absurdo) tratar de hacer una catalogación, 111n división en grinos cxactos. la experiencia y el lenglajc, las intenciones y los resultados se remontan a matrices ristintas, ticnden hacia conceptos diferentes de los significados y de las eventuales 
"funciones" del arte, y sin embargo, me parece obligatorio insistir en un punto: ya sea que en ellos se acentúe la voluntad narrativa o prevalezca una tensión metafísica, ya sea que los modos expresivos se inclinen hacia la abstracción y una especie de constructivismo o hacia un más evidente componente sígnico de tipo pictórico y en apariencia gestual ( $y$ estos aspectos están presentes en cada uno de ellos aunque con intensidad variada), estos artistas parecen rechazar todos una entrega incontrolada, más o menos neo-romántica, a una genérica exposición sentimental, a un lirismo informe o descriptivo. Lo cual no significa que esta aatitud común de todos ellos sea intelectualística, como lo demuestra el ejercicio constante de la ironía, de lo grotesco, de la alusión figurativa e inclusive social, correctivos mentales pero no formales, no separados de una realidad viva.

Puede suceder que una imagen pueda existir (ser) sin que se la perciba, pero ciertamente no podrá estar presente si no está representada. No es tan obvio como parece. Y si representar es seleccionar, no hay selección sin una toma de conciencia de las razones por las cuales se representa. Este es uno de los principios fundamentales de la imaginación creadora, sobre todo ahí donde se pretenda superar el obstáculo de una pura fabulación, más o menos privada de "sentimientos". En todo caso, muchos de estos artistas los más inclinados a la "narración" y los más ligados a una "nueva figuración", no se limitan a representar una imagen, o para decirlo mejor no se limitan a representar una serie de imágenes cuyo fundamento haya de buscarse sólo en las que para mí son las formas secundarias del conocimiento. Su estímulo básico, por cuanto sea inevitable que dependa de las diversas y personales características psicológicas y culturales de cada artista, no se diferencia sólo por estas razones. $\mathrm{Ni}$ el fin que ellos se proponen es sólo expresivo-visual. El crítico Tommaso Trini, al referirse a algunos de estos artistas, escribía que para ellos pintar es "pintar para hacer y no sólo para ser" y que su comunicación visiva no debe entenderse como una propuesta de mensaje definitivo, sino como una simple voluntad de comunicar. Lo cual me parece justo, porque implica una actitud de crisis, pero también de clara conciencia. En suma, brindar la obra en su hacerse, mostrar no sólo el fruto del esfuerzo creador en el momento de su solución sino también los distintos pasajes, la lucha, como propuesta viva y dinámica. De ese modo, en todos los artistas seleccionados para esta exposición, el pensamiento se suma a las formas "clásicas" del conocimiento y la expresión, sensaciones, memoria, asociaciones, etcétera) no sólo como elemento que disocia, asocia, percibe, ordena, sino como función selectiva y estructurante de una percepción, de modo que tal percepción no se quede como tal al reducirse a imagen, sino que más bien se cargue de conciencia para transmitir esta conciencia, ésta y no otra, al espectador. Para dar conciencia al hacer, para que el hacer se responsabilice. Por cuanto complejas, densas de referencias, alusivas, las obras de estos artistas nás intencionalmente relacionadas con la realidad se organizan en una narración clara, y ante un preciso análisis textual revelan significados inequívocos. En Adami, por ejemplo, la imagen surge de la observación de acontecimientos cotidianos de extrema banalidad y "vulgaridad", y comunica, filtrada por una sensibilidad morbosa, un juicio de orden ético. El ojo de Adami es documentalista, fotográfico, pero también extremadamente selectivo. No hay cuarto de lotel, anuncio luminoso (Exit, nunca Entrance), ducha, letrina pública, sala de espera, metro, cine, vagón ferroviario, estadio para carreras de perros o peleas de gallos, que no tenga su colocación precisa, pero también su significado emblemático: siem- 
pre ligares de transición, de soledad, de violencia, sobre los cuales se ejerce el malestar de una racionalidad corroída por el eros, de un juicio de orden moral que se reconoce una función propia inclusive en el interior de la esfera onírica (el "surrealismo frío" de Adami, como se ha auotado), hasta hacer de la minucia cotidiana más anónima el reflejo dramático de una condición casi a la Miller, de "pesadilla con aire acondicionado". Siempre, en la sínlesis convulsa de un objeto o en la metamorfosis objeto-personaje, emergen en Adani la voluntad de restituir en forma objetiva el angustioso absurdo de lo real; como por otra parte en ocasiones se nota un fondo puritano (en sentido amplio), que parece mantener en un difícil equilibrio atracción y repulsión, negación maligna y empuje regenerador. E1 resultado es, al mismo tiempo, sutil y trágico. Mientras que Adami está perpetuamente implicado en un mundo que lo atrae y lo disgusta, Baj lo observa con despego irónico, con una punta de escepticismo no priva de una casi dadaísta o patafísica voluntad profanatoria y se mofa de él sin recato. Lo demuestran sus inicios "nucleares", cuando su acusación a la disolución, inclusive física, del hombre era más abierta y evidente, y lo demuestran sus generales, sus damas de caridad, y sus actuales d'aprés Picasso. A Baj le basta con asumir como idea central una corbata, e inmediatamente la corbata, con irónica verdad, se convierte en "la condecoración preferida del hombre de hoy, y sustituye completamente las medallas y las distinciones civiles y militares". Desde la casta militar hasta la casta burguesa, sin olvidar a la casta intelectual. Grotesco: obra en que se unen una cierta extravagancia y una ridícula monstruosidad, en que lo dramático y lo cómico están mezclados y deformados hasta el punto de volver "monstruosa" la imagen. La naturaleza de Baj, que se revela incluso en el uso de los "objetos encontrados" y de las materias más imprevisibles, es en efecto una naturaleza grotesca, y su obra -aun en el divertintento en apariencia nás gratuito- transmite un juicio civil. Un juicio sin sosiego, que ha evitado siempre el sermoneo neo-realista y el manifiesto programático, y que quizás, precisamente por eso resulta tan excéntrico en la tradición más reciente, tan punzante, tan indisponente. En Tadini la línea de la estructuración intelectual es de las más abiertas, hasta el punto que la "narración" (no sólo de cuadro en cuadro, aisladamente, sino de un cuadro al otro, hasta tener una solución completa de lectura sólo al término, por así decir, cronológico, de la operación), se desarrolla según módulos de una verdadera y propia sucesión de tema, desarrollo, variaciones y conclusión. Tadini, en efecto, avanza casi siempre por grupos de obras, por ciclos, y no abandona sus temas. (El lugar de los niños, La vida de Voltaire, Paisajes occidentales, etcétera), hasta no llegar al umbral del riesgo de una inútil repetición. Pero antes los excava, los expone según toda interpretación posible. Por consiguiente, la lectura de una obra de Tadini se realiza en dos niveles distintos pero no separables, uno visual y uno de inteligencia, y si el nivel de los significados transmitidos podría inclusive parecer literario a quien quisiera insistir en un discurso de géneros, el nivel de las soluciones formales, y, más propiamente, del lenguaje visual, se ciñe, en todo caso a la pintura tout court, no está ni sofocado ni deformado por los elementos alusivos, de cultura que le sirven de motor y a los cuales se refiere. El juego, aunque mental, que Tadini pone en movimiento se basa en un mecanismo asociativo clarísimo: las portadas de Time con el hocico del mono, los managcrs sin cabeza, el letrero the end sobre paisajes geométricos definidos occidentales no requieren particulares explicaciones críticas. En Del Pezzo la tensión hacia la "narración" tan manifiesta en 
Tadini es de naturaleza contraria a una representación figurativa, de tipo antrogomóriico. Sus propensiones iniciales hacia un surrealismo que se injertaba de elementos populares y de folklore (ex-votos, capelos de vidrio para flores y santos en la mesita de noche, hallazgos del barroquismo napolitano, fragmentos de viejos juguetes pasados de moda), poco a poco nor así decirlo, se han congelado en una restitución más descarnada, que tiende a lo metafísico y a lo objetual hasta tocar el punto de una 1)ura, divertida, refinadísima expresión lúdica, pero sus resultados sólo en raros casos arriesgan la extenuación o el decorativismo gratuitos. Los objetos de Del Pezzo se aíslan en general en un espacio silencioso, roto aquí y allá por repentinos brotes de colores absolutos, casi cono indicaciones psicológicas de una fractura o de un concentrarse de una emoción única. Tienden a salir de la pintura, se ofrecen conno seĩiales. Tamhién laỵ ironía el Del Pezzo, pero predomina lo mágico, a veces recuerda, en términos rigurosos y con una acentuada tendencia hacia un dadaísno vuelto a visitar con instrumentos nuevos, la experiencia netafísica del arte italiano, $\because$ no sólo la del siglo $\mathrm{xx}$.

EI discurso que Pozzati desarrolla desde hace años en una vertiente muy parecida por in que toca a ciertos componentes, parece ser uno de los más indicativos del cambio que aconteció en la sensibilidad de los artistas de su generación al pasar de posiciones informales, o de signo-gesto, o de abstractismo existencial (como fue definido por algunos lacia 1960), hasta posiciones de recuperación del ejercicio crítico cn el acto creador. Sin pintura podría definirse relacionista, ciertamente es provectiva. Hace algunos años el artista declari: "Me considero un saqueador al tomar prestadas las cosas de otros..." Casi siempre en una misma obra el elemento racional y el elemento irracional conviven no tanto para indicar una posibilidacl de s'ntesis (que no se busca), sino para sulbrayar un contraste dialéctico, para evidenciar una anomalia, para hacer surgir 111 juicio renentino. Fignuras orgánicas desechas, de origen naturalístico, vagamente repugnantes, son colocadas en un espacio organizado geonétricamente, $y$ después asociadas a figuras que surgen de ese espacio o con idénilica prolifcración de formas geométricas o con referencias precisas evcrdaderos y propios renacimientos) figurativas o culturales, entendiéndose en cste caso por cultura esa vasta área de "civilización" a la que pertenecen los modos del atte y los modos de la vida cotidiana. La neo-figuración de Pozzati, razonacla y divertida, denistificatoria y brillante. no se niega a ninguna inclusión, a ninguna referencia. y cs la única -en este panorama- que contiene elenuentos pop autóctonos, ya sea que se trate de Carpaccio o de Leonardo, o de tomates, o de publicidad de un café.

De carícter igualmente extroverticlo, atento a las preminsas y a ciertis sngerencias rel furturismo, Scliifano agrede incluso la innagen más convencional con 131 imp)ulso lal (a menudo lírico, donde Pozzati distorsiona irónicamente), que pone en contraste su convencionalismo con sil uso, y, ell particular, con un uso que no coincide para nada con los fines que lo convencional podía haber preteudiclo en un principio. Aquí ramlićn nada queda confiado al azar, y nada puede ser interpretado según los juegos de la eilloción particular. Pero por cuanto las referencias a una condición del lombre en la sociedad, las remisiones a una adhesión precisa clcl artista a una posición ideológica, sean a veces tan explícitas que se satisfacen con una mera enunciación, como anoti el crítico Maurizio Calvesi, es indudable que Schifiuno tiende a encontrar "111 nuevo camino de lo abstracto y de lo absolito en la sencillez maguética de una innagen iniantil”, o, como quiera clue sea, lírica. 
El arte de Marialuisa De Romans, habiendo transitado por experiencias en las cuales se habian alcanzado ya resultados personales y definitivos, avanza inquieto a componerse en una tensa, silenciosa liricidad metafísica. El temperamento de la De Romans, como pueden demostrarlo las fases precedentes de su actividad creadora, descle una especie de informal panteístico y a veces gesturl, hasta una recuperación siempre más encarnizada de imágenes no consumidas, está doninado por una sensibiliclad cucendida, por una curiosidad de naturaleza fundamentalmente emotiva. Y sin enbargo es precisamente este arrojo originario lo que permite hoy a la artista, mediante utn riguroso control inclusive técnico, restituir un mundo de magia suspendida, donde juegan ambiguamente las interferencias de la memoria, las proyecciones de una sutil intuición, las asociaciones mentales. En su descarnado exponer, los objetos parecen ser tomados por sorpresa, absolutizados en un momento transitorio hasta asumir, en su solitaria objetividad, dimensiones imprevistas. La silla, las escaleras, la luma, las manos, se acomodan en un espacio que evita siempre el límite de la tela, en $111 n$ atmósfera de gracia $y$ de misterio, y rozan $11 n$ surrealismo que aun rechazarclo tolo componente morboso se v11elve inquietante. Lo que impresiona, en el método evocativo de la De Romans, es la relación entre la estaticidad y la clinámica de las figuras propuestas para una nueva lectura, su reconocibilidad objetual y su volverse extraños y distantes, en nna relación tiempo-espacio cuyo equilibrio está confiado a una obstinada voluntad de indagación que no renuncia ni a la realiclad le Ias cosas ni a los espectros de la imaginación.

Para Pistoletto el hombre es un "objeto" quc vive cul un espacio que no es otra cosal que un vacío. Y "vive" allí como tomado por sorpresa, inmovilizarlo en un instante lan transitorio como eterno, en una soledad refleja, junto con otras soledades. Verdaderas o fingidas, fingidas o verdaderas. El espejo no es diafrigna que subraya por comodidad los dos términos, que indica un "más acá" y un "más allá". Is más angustioso como una paráhola pirandeliana cute lábilmente demostrativo como el cuento de Alicia. No tiende a restitnir una realidad en términos ilusorios, sino a relicionar dos ilusiones. Más que de espacio se trata de tiempo, y, en efecto, sus jiguras chtran exactamente en él como los hombres pasan en el tienpo, individuos enuclearlos que entran en contacto sólo porque son como atraídos, en una porción de ese vacío, junto con otros individuos igualnente enucleados. Y del todo casualmente. 1.o que realizan, iunto con unos chantos elemenios en función evocativa psicoliogica más que ambiental, son gestos rituales, figuraciones jeráldicas. Pero cn nna clinensión física, no de ensueño. "El sentido nuevo de este arte visual o visionario éća cn el intercambio de nociones (objetivo). Y en stma, existe algo verdatero, estable, que son los personajes pegados sobre la lámina inoxidable; existe algo provisional, instantáneo y mutable que, a fin de enentas, somos nosotros, es decir, "la única cosa verdalera" (Maurizio Fagiolo Dell'Arco).

En Coroli la relación con el espacio, dimensión descontada, parece realizarse ci have a la medicla que el lombre y sus proyecciones condianals (desde lá ventana lasta el momumento, desde el reloj lasta el teléfono, y las letras del alfabeto) logran car. Fis un espacio arquitectúnico que el lombre, protagonista y antagonista. arlor y espectador, puede mudar como traspasándolo a fuerza el un juego de negativospusitivos donde 110 es seguro que el positivo, aun con esa aspereza de tabla en la que lan sido cortados perfiles absortos o con lo que se han consiruido cajas, necilnismos, objetos, esté dado precisamente por el concreto surcir de las figuras. Pero hriy tan- 
bién la sospecha, legitima, de un revés demostrativo de naturaleza ética (no sólo metafísica, o literaria) en la transcripción irónica de una crónica que se manifiesta con una puntual referencia al presente $\mathrm{y}$ con la alusión a una historia y a una cultura reconsideradas, y que Ceroli utiliza con inteligente conmistion. "Yo quiero realizar la cosa": la objetualiclad, toda inventada sobre módulos que se dirian tradicionales y resielta en ciertos casos con un refinamiento casi estetizante, es el aspecto más patente de un arte que escapa al pop y a lo abstracto.

Considero justo incluir en esta colectiva algunas obras de Romagnini, que murió trágicamente en 1964, no sólo para rendir un homenaje de cariño a un hombre y a un artista que compartió el trabajo y la esperanza de mi generación, sino también, y en particular porque me parece que Romagnoni sigue siendo el ejemplo quizás más típico del momento en que el joven arte italiano comenzó a realizar, alrededor de 1960 , de modo consciente y sobre raíces comunes, esas decisiones que he intentado indicar en esta sede en sus diversificaciones sucesivas. En Romagnoni están todos los fermentos de aquellos años, y para darse cuenta es suficiente, a distancia, releer algunas de sus declaraciones. "Nuestro deseo de unidad no debe aplastar" la complejidad y contradictoriedad de lo real", escribia en 1960, y ya en su pintura se revelaba intensamente la presencia de organismos que, por cuanto aún sofocados por un impulso de tipo expresionista, tendian a organizarse de acuerdo con una lógica compositiva en la que conviven la fisicidad más densa y una fuerte carga de emoción incluso civil. En él, el espacio todavía no se abstractiza. El espacio es el personaje que se dilata hasta englobar todo lo que está a su alrededor, los objetos que son su naturaleza, las referencias a su propia condición. O bien: el personaje entra en el espacio como en un cuarto, se dilata, absorbe el cuarto. $Y$ es en esta forma que narra. La narración, que en otros artistas ha asumido modos expresivos e intenciones distintas, se articula en él según una proposición de tipo clásico, y se debe leer, por lo tanto, exactamente como se lee una secuencia escrita. Pero Romagnoni, cuando se inter rumpió su obra, ya estaba desnudando cada vez más su lenguaje de aquella complejidad y contradictoriedad con las que quería habérselas, y estaba a punto de alcanzar indicaciones más abiertas y unitarias, que habrían conducido a una reencontrada claridad inclusive sobre vertientes más racionales.

En1 este sentido el camino seguido por Aricó es ejemplar. Habiendo partido de posiciones no muy diversas, dotado de una sensibilidad agudísima para el signo y el color, siempre dominado por la voluntad de estructurar racionalmente, intelectivamente, toda vibración emotiva para fijar el momento más sutil, aquel instante en el que el espacio y el tiempo se encuentran y se unen. Aricó ha tratado de penetrar en la fisicidad de lo real hasta agotar todas sus presencias alusivas, pero sin olvidar nunca su existencia. Lentamente, en un proceso riguroso que llega lasta los límites del sacrificio de sus dotes más evidentes (pero el efecto superficial nunca le ha interesardo), su operación creadora procede en dirección reductiva, de síntesis, con una linearidad lógico-poética. De lo real, lo que Aricó busca alıora es la medida. En las "puertas" actuales, en los arcos, en el juego de perspectivas y de descomposición y recomposición de ciertos objetos, cuyos volúmenes son delineados en una especie de Trompe loeil a base de imperceptibles variantes tonales, no es el símbolo, o ya no es solamente el símbolo lo que se vuelve a tomar, sino más bien el concepto constructivb, la racional delimitación y fijación de los espacios, internos y externos, en una ditícil búsquedii de absolutos que se concretan en formas y estructuras que parecen doni- 
nadas como por una obsesión matemática en busca de una nueva "divina proportione". También en Pardi se puede hablar de arquitectura, de una arquitectura en todo caso evidente, circunstanciada, hecha precisamente de columnas, de techos, de pisos, de tejados, de ventanas. Pero en un distinto alternarse de razones y tentativas, que, descle un juego inicial de "sustracciones" que agregaban densidad y peso expresivos más a los elementos amputados que a los dejados íntegros en su soledad hasta la representación de jardines colgantes que imitaban la artificiosidad de una naturaleza sofocada e irónicamente evocada, han llevado al artista a las soluciones actuales. Hoy, la búsqueda de Pardi es una tentativa de "profundizar algunos problemas que atañen a las relaciones: naturaleza-ambiente artificial, geometría-organicidad, rectacurva". Con su obra cada vez más dirigida hacia soluciones estructurales, y en la que están comprendidos al mismo tiempo los términos puestos en conflicto, Pardi evidencia también los motivos teóricos del "hacer arte" que están tras de todo resultado alcanzado, que viene a plantearse, de esta forma, como unidad significante cuyos elementos constitutivos (las relaciones internas dadas incluso por los distintos materiales usados en un mismo cuadro), quedan, visibles para subrayar una dinámica continua, una escansión elegante y equilibrada en su concreción. Castellani parece haber querido sustraer su obra, desde un principio, a todo tipo de dominio de la pintura, de la escultura, de la arquitectura. No para negarlas, sino para capturarlas y fundirlas en una unidad dinámica que restituya toda referencia objetual en términos conceptuales. Inevitablemente, su materia es la luz, y su color es el blanco, suma perfecta de todo color. Entre los primeros en romper con el informalismo para una superación no figurativa, y que hicieron suya la lección de Fontana con gran inteligencia $\mathrm{y}$ en modo personal, Castellani rechaza sin términos medios cualquier referencia a la naturaleza o a la emoción exteriorizada, cualquier tentación de parábola o de símbolo que sugiera la presencia de "otra cosa" diversa de lo que él considera idea pura. Y la primera cosa que se rechaza es la superficie de la obra entendida como tal, es decir entendida como simple elemento de conveniencia. La obra no es algo que se apoya en una pared para simular algo que está fuera de ella, sino que es la pared, es decir, un espacio que debe concebirse como totalmente abstracto e ilimitado, que se anima rítmicamente en una progresión, o acumulación, de positivos y negativos de los cuales la luz es el objeto y su contrario, casi originada por sí misma en sus infinitas variaciones, expansiones, éxtasis y reanudaciones. La de Castellani, escribió Guido Ballo, después de haber señalado sus orígenes neo-plásticos, "es una palabra abierta, que se opone a todo decadentismo complaciente".

También para Alviani la visión se resuelve en luz, pero en los mecanismos ilusionistas (que mudan continuamente y físicamente las perspectivas con efectos que rozan soluciones casi plásticas, aunque aéreas e impalpables), la superficie es asumida como área de acción necesaria, se impone en una forma del todo explícita. Alviani no esconde el medio, sino que lo eleva a la categoría de un fin por alcanzar. Se podría decir, en algún modo, que el verdadero medio es el espectador, ya que es a partir de la acción del espectador como, a través de ese medio, por cuanto predispuesto, llegará a componerse la obra. Una obra, pues, variable, abierta a una interpretación continua, que mientras se ofrece como forma-luz plantea un programa de educación visual. La luz es capturada y refractáda como un fenómeno cuya unidad está dada al mismo tiempo que su variabilidad interior. Como se ha subrayado, si aquí hay metafísica se trata de una metafísica de la técnica. Y no es una casualidad 
que Alviani no haya renunciado nunca a una posible recuperación de la vertiente factual del arte, a un contacto con el mundo de las "necesidades", sin desdeñar ni siquiera una coincidencia con el "diseño".

En su "nuevo geométrico", Carrino lleva a los límites extremos el abandono de los géneros. Su discurso es áspero, obstinado, y enıbiste pesadamente, más que contra la técnica, contra la teoría del arte. En el esquema cúbico cerrado que le es más congenial, los módulos escalonados y en forma de $\mathrm{T}$ que lo componen tienen la consistencia ambigua de una unidad lista para dispararse en una dinámica posibilidad de variantes, crean un continente cuyo contenido se vuelve cada vez más agresivo y pide ser seccionado, empujado, movido, trastornado por un gesto que lo volverá a llevar, siempre a su origen unitario. La intervención del espectador sobre estas formas es recluerida por su misma composición modular, desde su "interior", pero no es indispensable. $Y$ es la prueba que no se trata de un problema de constructivismo para gozarlo exteriormente, "estéticamente", sino de un problema de construcción tout conrt. Una construcción, o reconstrucción, de una forma cerrada, que luego está como reenviada, como confiada a una pura intervención mental. El arte de Carrino es un arte conceptual por excelencia, que se explica en las inmediatas cercanías del concretismo, pero que no se conforma con soluciones visuales. Fuera también de la escultura, en forma enigmática. Inclusive didáctico, pero sin las instrucciones para su uso.

Con Parzini estamos en plena geometría. Su operación creadora, por cuanto tenga raíces en una precisa tradición pictórica italiana, se sustrae a matices tonales o psicológicas, a toda alusión naturalista. La imagen nunca se dispersa en la superficie, ni es fragmentaria por deseo de superar los línites del cuadro, ni parcial.

Lo oval, que es su forma preferida, no corre el riesgo de remitir a un concepto de perfección originaria, ya que se plantea sencillamente como delimitación de un espacio en chyo interior lo que se mueve, lo que altera y se desconpone y recompone sigue sienclo espacio. La figura geométrica of rece de sí misma, a veces, los varios componentes aun geométricos, el trazo de sil construcción de ensamblaje y en profundidad, y termina por sugerir una escansión ideal que ha dejado el sitio al mecanismo exacto (lel movimiento y de la inmovilidad. Una representación del nacimiento y de la vida de las formas que se expresa "con silencioso estupor de relaciones analógicas, con referencias intuiclas y buscadas con obstinada seguridad lírica". (G. Ballo).

En la "técnica de la visión" que se diría es fara Dorazio instrumento y fin de la búsqueda creadora (es como si Dorazio nunca pretendiera ofrecer a la mirada un "resultado", sino más bien una de las fases a través de las cuales una obra se realiza un momento de un "work in progress" más amplio), los componentes básicos son la luz y el método. Aquí la luz no es superficie, no que es fluida o impalpable profundidad. La transparencia está dada por líneas de fuerza que adquieren solidez en haces, en tranias, en arquitecturas, sobre las cuales se ejercita un agudísimo, refinado juicio. Dorazio extrae del vacio, del blanco, el espectro y el gráfico de un movimiento secreto, interior, altamente poético. Y por cuanto s11s "catedrales", sus "rosetones", sus fugas de perspectivas, sus retículos tupidos que parecen remitir a mundos celestes, sean perfectamente abstractos y mentales, los momentos en que se establecen tienen una estupefaciente, límpida concreción. No es casual que sugieran formas conocidas, pertenecientes a una dimensión humana o natural. Quizás también porque el problema que más preocupa al artista es el relativo al hacer, no al representar una operación perceptiva. Así cono es raro que una obra de Dorazio sea fría. Su carga emotiva está 
DOI: http://dx.doi.org/10.22201/iie.18703062e.1972.sup1

retenida, organizada, pero no sofocada, o considerada en todo caso con excesiva sospecha, y lo denuestran sus obras más recientes, en donde el formato mismo subraya el ímpetu. El uso más "pictórico" del color, la densidad de los tonos, las yuxtaposiciones siempre más apretadas e intrincadas de los varios planos crean una sensación jlástica más que de signo, revelan facetas inesperadas, masas, evocan resonancias distintas. Quedan, es verdad, en una área abstracta, pero es curioso cómo frente a una obra reciente de Dorazio se perciban (al menos a mí así me sucede), asociaciones no lejanalas de una "metafísica" de la visión, casi de nubes que se congelan en un cielo radiante, feliz, de jardín del Edén recuperado.

En Perilli la tendencia a la narración tiene orígenes lejanos, nace de la voluntad de superar las posiciones informales dominantes, se nutre de razones distintas de las que hemos subrayado en otros. Su modo de narrar, por ejemplo, no se plantea como recuperaciónı neo-figurativa, ni siquiera en términos generales, o con componentes que puedan relacionar su discurso con las solicitaciones clásicas, ya probadas, de la metafísicn italiana o del surrealismo. De la 11arración, que puede emerger en él tanto de la crónica como del sueño, tanto de la memoria como de asociaciones de tipo intelectual, más que la representación cerrada, le interesa el proceso de duración. Por esto se confía al una subdivisión del cuadro en espacios sucesivos tomados de la técnica de las historietas. Pero en sus strips los personajes no tienen nada de naturalista: pequeños nonstruos cotidianos, inventados con ironía, teducidos a nudos de signos veloces, a Jarvas, a detalles de órganos humanos agigantados según una función expresiva caracterizante, initan una representación cuyo director denota una fuerte carga de "humor" y cle racionalidad, pero también de sutil lirismo. Los títulos mismos, que reflejan en la obra un componente "literario", permiten comprender nuuy bieı la operación de Perilli. Una operación que revela su positiva ambigüedad allá doncle los personajes desaparecen para dejar el papel de protagonista a ciertas construcciones abstractas, monumentos absurdos donde el concepto de duración se explica no en secuencia, linealmente, sino en profundidad en el interior.

"Los signos tienen un poder referencial por el que, aun siendo relativos solanente a sí mismos, pueden hacer las veces de otra cosa." Esta declaración de Novelli es una indicación de una poética que aclara inmediatamente dos aspectos de su pintura: el uso del signo (que se convierte en señal, letra, palabra), como prolongación concreta, vibrátil, sensible, de la mente, de las ideas, trazo de un sismógrafo íntimo que al registrar tocla mínima sublevación se constituye como lenguaje autónomo, y la proyección alusiva, constante, admitida sin temor, de una realidad que por cuanto no evite ni siquiera los datos de la crónica está constituida esencialmente por el lenguaje, viviseccionada en fornla minuciosa y filtrada, y después colocada -manteniendo en suspensión todo hallazgo, sin selecciones aparentes- en un espacio fluido. El narrar de Novelli escapa a una disposición lineal o cronológica, prefiere la aglomeración de sus varios componentes, como sucede por ejemplo en muchos textos poéticos que me complace llamar neorrománticos, ya estén confiados a una acumulación ennotiva e imaginosa o a una atomización semántica: las figuras, los objetos, los espacios, las palabras, en una iconografía rica y laberíntica que sabe a mapa geográfico o a herbario revuelto. En Novelli el signo, que difícilmente podrá definirse en térninos de automatismo de tipo surreal, es el agente central de un equilibrio buscado entre la palabra y la imagen, entre el inpulso emotivo y el control de la razin.

Agresivo, excavado, enredado, el objeto evocado por Scallavino no emer $x$ e de 
espacios anónimos, sino de una soledad tensa, de la cual es componente inseparable, de un silencio aludido apenas por grises tenues, y fluctúa con una corposidad distorsionada en una alusividad suspendida, con resonancias otrora expresionistas y hoy fríamente alucinantes. Un mundo mental, sordo, que recuerda la desértica fabulación de Beckett, pero que, a despecho de todo, sigue siendo un mundo que todavía es el nuestro. En Scanavino la poética del signo se ha liberado de todo automatismo, de todos aquellos tonos existenciales que al principio estaban realizados en una materia que, por cuanto controlada y lúcida, mantenía tonos de gestualidad pictórica. Artista severo, Scanavino no se ha conformado, ha pasado de módulos representativos en los cuales se advertía una voluntad de excavación total de lo inconsciente, a una delimitación siempre más neta y racionalizada de las presencias que salen a la supetficie de sus obras. Han desaparecido las caligrafías emocionales, los esgrafiados, y el espacio ya no es una pared que se debe exorcizar. Ahora la atención del artista está toda dirigida hacia lo que parece en ciertos casos un despojo abandonado por la conciencia. Para analizar, y después restituir como señal, o simbolo, a su naturaleza original. No debe asombrar que permanezca ambiguo y precario; hemos perdido el sentido de ello, o nos hemos limitado a reconocerlo nominalmente, no por su significado, por su forma, por su pertenencia al mundo. El artista lo repite y lo vuelve a proponer en todas sus relaciones posibles, momento de un continuum. Es pan, ventana, tierra, raíz, puerta, maraña de hojas, madeja de hilo. En su operación sensualmente intelectual, y hoy nos damos cuenta de ello, Scanavino no ha sido nunca un pintor abstracto.

Al esbozar algunos aspectos de la personalidad de cada uno de los artistas que forman parte de esta colectiva, he tratado de mostrar -aunque no en modo directolas matrices comunes, los puntos de contacto, las motivaciones paralelas y los resultados autónomos. Había pensado, en un primer tiempo, en agruparlos en áreas distintas, que hubieran sido fácil de encerrar en definiciones como: 1. "metafísica y narración", 2. "abstracción y construcción", 3. "la razón y el signo". Me he dado cuenta que una distinción de este tipo, aunque legítima en términos generales y de conveniencia, no habría destacado, quizás, con suficiente evidencia las variables, Ias interferencias, los movimientos interiores de una experiencia que sigue siendo común y significativa y que me parece que se expresa mejor con una figura crítica cíclica, fluida.

Se trata de una experiencia todavía móvil, y sin embargo precisa, típicamente italiana.

Roberto Sanest

Datos biográficos de los artistas: Valerio Adami, nacido en Bolonia en 1935, vive y trabaja en Arona, Novara. Getulio Alviani, nacido en Udine en 1939, vive y trabaja en Udine. Rodolfo Arico, nacido en Milán en 1930, vive y trabaja en Milán. Enrico Baj, nacido en Milán en 1924, vive y trabaja en Milán. Nicola Carrino, naciclo en Tarento en 1932, vive y trabaja en Roma. Enrico Castellani, nacido en Castelmassa (Rovigo) en 1930, vive y trabaja en Milán. Mario Ceroli, nacido en Castelfrentano en 1938, vive $y$ trabaja en Roma. Marialuisa de Romans, nacida en Milán, vive y trabaja en Milán. Lucio del Pezzo, nacido en Nápoles en 1933, vive y trabaja 
en Miján y París. Gastone Novelli, nacido en Viena en 1925, fallecido en Milán en 1968. Piero Dorazio, nacido en Roma en 1927, vive y trabaja en Roma. Cianfranco Pardi, nacido en Milán en 1933, vive y trabaja en Milán. Luigi Parzini, nacido en Casale Monferrato en 1925, vive y trabaja en Novara. Achille Perilli, nacido en Roma en 1927, vive y trabaja en Roma. Michelangelo Pistoletto, nacido en Biella en 1933, vive y trabaja en Trrín. Concetto Pozzati, nacido en Vó Vecchio, Padua en 1935, vive y trabaja en Bolonia. Bepi Romagnoni, nacido en Milán en 1930, fallecido en Cerdeña en 1964. Emilio Scanavino, nacido en Génova en 1922, vive y trabaja en Milán, Calice Lignre (Savona) y París. Mario Schifano, nacido en Hons, Libia en 1934, vive y trabaja en Rona. Emilio Tadini, nacido en Milán en 1927, vive y trabaja en Milán.

Catálogo: 1. el ring, 1968, acrílicos s/tela $243 \times 365 \mathrm{~cm}$. 2. superficie y textura vibrátil progresivas, 1961/67, aluminio, $224 \times 98 \mathrm{~cm}$. 3. relieve en reflexión ortogonal, 1967, acero, $160 \times 160 \mathrm{~cm}$. 4. arco azul, 1970, acrílicos s/tela $360 \times 270 \times 10 \mathrm{~cm}$. 5. Punching General, 1969, plástico acolchado, $140 \times 85 \mathrm{~cm}$. 6 . militar condecorado, 1967, técnica mixta s/tela, $91 \times 75 \mathrm{~cm}$. 7 . retrato de Dubuffet, 1968 , celuloide, 137.5 $\mathrm{x} 149 \mathrm{~cm}$. 8. construction/destruction, 1970, 8 módulos en hierro, $100 \times 100 \times 100$ $\mathrm{cm}$. 9. superficie blanca, 1966, tela barnizada, $200 \times 200 \mathrm{~cm}$. 10 . mariposa, 1966, madera, ancho $110 \mathrm{~cm}$. 11. mariposa, 1967, madera, ancho $110 \mathrm{~cm} .12$. mariposa, 1967, madera, ancho $110 \mathrm{~cm}$. 13... pero de la nada el vacio del aire, 1970, acrílicos $\mathrm{s} / \mathrm{tela} 140 \times 110 \mathrm{~cm} .14 \ldots$ y el aliento blanco de las presencias invisibles, 1970 , acrílicos s/tela $154 \times 110 \mathrm{~cm}$. 15.. y la azul curva del día alrededor de tu noche, 1970 , acrílicos s/tela $154 \times 110 \mathrm{~cm}$. 16. el tigre, 1967, óleo y madera pintada s/tela $146 \times 114 \mathrm{~cm}$. 17. fábrica geométrica, 1963, madera pintada, 150 x $117 \mathrm{~cm} .18$. fuente, 1967/68, madera pintada $180 \times 70 \times 50 \mathrm{~cm}$. 19. viaje en el pais de las maravillas, 1965, técnica mixta s/tela $200 \times 400 \mathrm{~cm}$. 20. alma primera, 1969, óleo s/tela, $175 \times 350 \mathrm{~cm} .21$. en cruz $I V$, 1969, óleo s/tela, $175 \times 175 \mathrm{~cm}$. 22. jardín pensil, 1970, madera pintada s/acero 3 paneles, $200 \times 100 \mathrm{~cm}$. 23. jardin pensil, 1970, acero y latón, $200 \times 100 \mathrm{~cm}$. 24. oval con azul s/bruno, 1970 , óleo s/tela $130 \times 162 \mathrm{~cm}$. 25. oval, 1969, óleo s/tela, $146 \times 162 \mathrm{~cm}$. 26. teorema, 1967, técnica mixta s/tela $200 \times 450 \mathrm{~cm}$. 27. el hada Morgana, 1969, técnica mixta s/tela 180 x $180 \mathrm{~cm} .28$. él y ella con anteojos, 1970 , collage s/aluminio, $230 \times 120 \mathrm{~cm} .29$. de y para Carpaccio, 1969, acrílicos y madera s/tela $200 \times 175 \mathrm{~cm}$. 30. de y para Carpaccio, 1969, acrílicos y madera s/tela $200 \times 175 \mathrm{~cm} .31$. allá arriba s/las montañas... 1970 óleo y acrílicos s/tela $200 \times 175 \mathrm{~cm}$. 32. narración, 1962, óleo s/papel s/tela, $150 \times 150$ $\mathrm{cm}$. 33. narración, 1963, óleo s/papel s/tela $100 \times 100 \mathrm{~cm}$. 34. narración, 1963, óleo $\mathrm{s} /$ papel s/tela $100 \times 80 \mathrm{~cm}$. 35. imagen, 1966, óleo s/tela $150 \times 150 \mathrm{~cm}$. 36 . forma atada, 1967 , óleo s/tela, $150 \times 150 \mathrm{~cm}$. 37. en espera de, 1968 , óleo s/tela, $150 \times 150$ cm. 38. todas estrellas, 1967, óleo s/tela y plástico $200 \times 400 \mathrm{~cm}$. 39 . arqueología, 1970, acrílicos s/tela, 162 x 130 om. 40. color \& Col., 1970, acrílicos s/tela, 195 x $130 \mathrm{~cm}$.

marco chilet. Exposición de pinturas, presentada por la Galería C. D. I. del Centro Deportivo Israelita, Av. Manuel Avila Camaclıo número 620, el 25 de marzo.

TEÓdulo Rómulo. Exposición de dibujo, grabado y pintura, presentada por la Galería José María Velasco, INBA/S. E. P./Peralvillo 55, el 26 de marzo.

AARón PIÑA MORA. Exposición Taraliumara / 1971, presentada por el Museo de Arte Moderno, INBA, Galería de Exposiciones Temporales, Sala Derecha. Planta Baja, durante el mes de marzo. 
Catálogo: 1. músico tarahumara, 1970, $60 \times 50$, mixta s/maclera 2. mesa tarahumara, $1970,65 \times 50$, mixta s/madera 3. joven tarahtmara, $1970,60 \times 50$, mixta s/madera 4. flautista tarahumara, $1970,60 \times 50$, mixta s/madera 5. músico tarahunara, 1970 , $65 \times 50$, mixta s/madera 6. danzante tarahnmara, $1970,65 \times 50$, mixta s/madera 7 . orador tarahumara, $1970,65 \times 54$, mixta s/madera 8. tarahumara con bastón, 1970 , $65 \times 50$, mixta s/madera 9. corredor tarahumara, $1970,65 \times 50$, mixta s/madera 10. pareja tarahumara, $1970,60 \times 50$, mixta s/madera 11 . tema tarahumara: los novios, 197012 . vieja tarahumara, $1970,73 \times 50$, mixta $\mathrm{s} /$ madera 13 , mujeres tarahumaras, $1970,73 \times 50$, mixta s/madera 14. grupo tarahumara, 1970, 81 x 50, mixta $\mathrm{s} /$ madera 15 . tambor taraliumara, $1970,81 \times 60$, mixta s/madera 16 . grupo tarahunara, 1970, $81 \times 60$, mixta s/madera 17 . procesión tarahumara, $1970,80 \times 60$, mixta s/madera 18. niño tarahumara, 1970, 65 x 50, mixta s/madera 19. madres tarahumaras, $1970,73 \times 50$, mixta s/madera 20 . entierro tarahumara, $1970,65 \times$ 92, mixta s/madera 21. madre tarshumara, $1970,65 \times 50$, mixta s/madera 22. madre tarahumara, $1970,60 \times 50$, mixta s/madera 23. toma tarahumara: la despedida, $65 \times 50$, mixta s/madera 24, mísico tarahumara, $1970,60 \times 50$, mixta s/madera 25 . mísico tarahumara, $1970,61 \times 50$. mixta s/madera 26. músicos tarahumaras, 1970 , $65 \times 54$, mixta s/madera 27. gobernador tarahumara, 1970, $60 \times 50$, mixta s/madera 28. danza tarahumara, 1970, 65 x 50, mixta s/madera.

KURT LAISch. Exposición de abstractividades, presentada por la Galería Arvil, Hamburgo 241 , el 29 de marzo.

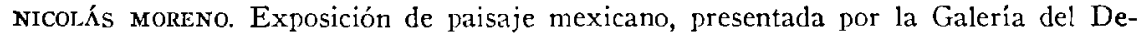
partamento de Turismo de Michoacán, Rinconada del Nigromante, del 12 de marzo al 3 de abril, en Morelia, Mich.

Catálogo: 1. el valle desde la loma, 1956, óleo/masonite 2. San Lázaro 1, 1957, óleo/ masonite 3. el barco viejo, óleo/masonite, 1957 4. San Miguel de las Ahuamas, 1958, óleo/tela 5. una mujer sola, 1960, óleo/tela 6. tugurios, 1961, óleo/tela 7. ladrillera, 1963, óleo/tela 8. paisaje de Coatzacoalcos, 1963, óleo/tela 9. mano sobre mano, 1960, óleo/tela 10. San Lázaro 2, 1964, óleo/tela 11. la barranca, 1965, óleo/ tela 12. selva, 1967, óleo/papel/madera 13. manglares, 1967, óleo/papel/madera 14. rocas, 1968, óleo/tela 15. el árbol caído, 1968, óleo/tela 16. ahuehuetes mucrtos, 1968, óleo/tela 17, el nopal en las rocas, 1968, óleo/tela/madera 18. maguey seco, 1968, encáustica/madera 19. nopal, 1969, encáustica/madera 20. minas de arena, 1969, óleo/tela/maderá 21. cañón de la huasteca, 1969, óleo/papel/madera 22. la montaña, 1969, óleo/papel/madera 23. troncos y raíces, 1969, óleo/tela/madera 24. la cañada, 1969, óleo/tela/madera 25. el río, 1970, óleo/tela/madera.

\section{ABRIL}

Carios cuéld.ar. Exposición de pinturas presentadas por el Instituto Mexicano Norteamericano de Relaciones Culturales, A. C., Galería Nabor Carrillo, Hamburgo 115, del $1^{\circ}$ al 19 de abril.

Datos biográficos del artista: Carlos Cuéllar nació en México en 1943.

Julio Ávila. Exposición presentada por el Centro Cultural Villa Olímpica, en la Villa Olimpica, el 2 de abril.

Datos biográficos: Julio Avila, ingresó a la Escuela de Diseño y Artesanías en 1964. Se graduó como Maestro de Vitrales en 1966. 
lucio acosta cerra. Exposición de óleos, presentada por la Escuela Nacional de Artes Plásticas, Academia 22, del 6 al 26 de abril.

Catálogo: 1. pájaro silbador (serie de los pájaros), óleo s/tela 2. tucán labrador (serie de los pájaros), óleo s/tela 3. pájaro agorero (serie de los pájaros), óleo $\mathrm{s} /$ tela 4. aprendiz de vuelo (serie de los pájaros), óleo s/tela 5. liturgia pagana, óleo s/tela 6. collares indios, óleo s/cartón 7. los molinos, óleo s/tela 8. jardín petrificado, óleo s/tela 9. donde claudica el hidrógeno, óleo s/tela 10. composición, óleo s/tela 11. hombre sofisticado, óleo s/cartón 12. fuga en la noche de mayo, óleo s/tela 13. nocturno para un cacique difunto, óleo s/cartón 14. embrujo del paye, óleo s/cartón 15. visión ancestral, óleo s/cartón 16 . llorona pureña, óleo s/ cartón 17. hermanas de la tierra, óleo s/cartón 18. jerarca calchaqui, óleo s/cartón 19. tres ex-líderes de parro, óleo s/cartón 20. impresiones de la puna, óleo s/cartón.

KAETHE KOLLWitz (grabados) y PINTURA ITALiana. Exposición presentada por las Galerías Mer-Kup, Molière 328-C, el 6 de abril.

170 miniaturas. Exposición colectiva, presentada por la Galería Edvard Munch, Paseo de la Reforma 489, del 12 de abril al 3 de mayo.

Nombre de los expositores: Calderón, Cardona, Carreón, Dekeizer, De la Rosa, Fujikawa, Greta, Jurado, Kepenyes, Kristil, Millioud, Thomas, Toral, Victor, Vivar, Zalathiel, Zavala.

LUIS gonzÁlez zÁrate. Exposición de obras, presentada por la Galería Chapultepec, INBA, Insurgentes Sur $N^{\circ} 11$ bis, el 13 de abril.

Hace algunas semanas conocí en Oaxaca a un grupo de estudiantes del Instituto Tecnológico Regional. Conversamos, y desde un principio me admiraron los conocimientos y la pasión de esos mucliachos. Uno de ellos no participaba en las discusiones, sus anigos dijeron que prefería expresarse mediante la pintura. Más tarde vi algunos de sus cuadros $y$ supe que se llamaba Luis González Zárate.

Nació hace apenas veinte años en un pueblo de Oaxaca, Santa Catarina Cuanana, y nunca ha estado en un colegio de artes plásticas: es alumno de tercer año dé ingeniería mecánica. Pero desde hace tiempo se dedica con fervor a pintar y ya ha expuesto en Oaxaca y en Monterrey. Su técnica predilecta es la acuarela oleada. Sus colores: verdes, rojos, amarillos. Sus temas, casi diría: sus obsesiones, son las imágenes del campo, la dualidad que existe entre hombres $y$ animales y la dimensión erótica del ser humano. Una poderosa corriente de sensualidad galvaniza su obra. Tiene los ojos llenos del esplendor de su región: una zona (¿habrá necesidad de repetirlo?) privilegiada en los tiempos prehispánicos y coloniales (Miguel Cabrera, el mejor pintor del virreinato, era zapoteca) y que en este siglo nos ha dado un Tamayo y la diaria maravilla de sus artes populares. González Zárate posee la fuerza y la debilidad del autodidacta. No se parce visiblemente a ningún maestro: pinta como si fuera el primer hombre que pintase en el mundo. A veces sus colores devoran el cuadro y éste se encuentra lleno de cosas. Por tanto sus defectos no son de carencias sino de abundancias. Hallará su propia disciplina y encauzará su fuerza sin perderla. Se encuentra en el mejor camino para convertirse en un auténtico pin- 
tor. A partir de su primera exposición en México, tenemos que contar con González Zárate.

José Fmilio Pachroco

José Julio gaona. Exposición de grabados, presentada por la Galería Chapultepec, INBA, Insurgentes Sur $N^{\circ} 11$ bis, el 13 de abril.

Pavlata. Exposición de 18 óleos y un tríptico, presentada por el Museo de las Culturas, Moneda 13, el 13 de abril. (INAH, S. E. P.)

alejandro chacón pineda. Exposición de obras recienles (rumbo al rejoso), presentada por el Instituto Francés de América Latina, Nazas 43, el 14 de abril.

No pretendo caer en eso de "dar algo de mí o algo de los demás"; sería tener una justificación al verdadero acto de experimentar y vivir las relaciones de color, forma y espacio. Así como estar haciendo evidente tales o cuales hechos naturales, sería estar representando. Debemos recuperar la naturaleza a través del ejercicio de la conciencia. Tampoco pretendo llegar a una significación de esos "hechos naturales"; se dirá "qué fácil, no quiere comprometerse" pero uno debe ser realmente el que crea esos nuevos compromisos. Tratar de encontrar o "inventar" cierto estilo o forma que caracterice deteminada personalidad, sería olvidarse de lo otro, de lo que realmente nutre a una obra y a muestro hacer, o sea la verdadera relación del hombre con el mundo.

Dar un nuevo sentido a las formas y sus relaciones $y$ abandonarlas cuando cobren significado.

El trabajo del pintor está penetrado por su experiencia del mundo... crear estados que nos lleven a una relación directa con las esencias de la naturaleza, con las esencias mismas de nuestro ser. Bienvenidos aquellos que lo perniten.

\section{Atejandro Chacón Pineda}

I.IBros de la INDIA. Exposición presentada por el Instituto Nacional de Bellas Artes, la Secretaría de Educación Pública, la Secretaría de Relaciones Exteriores, Dirección General de Asuntos Culturales, Embajada de la India en México, Vestibulo del Palacio de Bellas Artes, el 15 de abril.

JAmes pinto. Exposición de pinturas recientes, presentada por la Galería Misracli, Génova 20, el 15 de abril.

Javier padilla. Exposición de feticlies, presentada por el Departamento clel Distrito Federal, Dirección General de Acción Cultural y Social, Galerías de la Ciudad de México, Alameda Central, Sala Hidalgo, del 15 de abril al 8 de mayo.

Soy parte del todo de la naturaleza, siempre intenté conquistarla, pero descubrí que hay que encontrar nuestro lugar y nuestra función en ella, por eso he tratado de quitar la máscara con que siempre lá he visto, para verla en toda su desnudez sin que la oscurezca ningina palabra. 
Casi todo se puede valorar y analizar, sin embargo, la intuición y el instituto, que son esenciales para la compresión de la experiencia, han sido los medios verdaderos para desarrollar mi pintura. A veces los conceptos me envuelven en la confusión.

Creo en la pintura individual del pasado y del presente. No creo que el pintor deba ser un cronista de su época.

Pinto para afirmar y nunca negar, para experimentar la fascinación de la libertad (aun cuando a veces obtengo lo contrario), para afirmar un estado de ánimo y una actitud que me permita alcanzar las fuentes vivas de lo imaginario y lo maravilloso, para deslindar la forma por medio del color e integrar elementos diferentes con la intención de oponerme a expresiones ambiguas, para plasmar en un rito de magia, un deseo o una intención, para intentar la sintesis de la forma de lo que me rodea, para conjugar y conciliar el mundo exterior real y el de los sueños, para lograr la plena identidad del tiempo y del espacio, para disminuir mis obsesiones, para buscar $y$ encontrar, para recordar y olvidar, para llorar y reír, para poseer por sensualismo, por anor, para inventar y pensar, para dar algo y a veces la propia vida.

El pintor es el último de los brujos sobrevivientes; su obra es su fetiche.

Javier Padilla

Genoveva cámara. Exposición de pintura cinética, presentada por el Departamento del Distrito Federal, Dirección General de Acción Cultural y Social, Galerías de la Ciuclad de México, Sala Juárez, Alameda Central, del 16 del abril al 8 de mayo.

ELIÚ vegA. Exposición fotográfica, presentada por la Galería José María Velasco, INBA/S. E. P./Peralvillo 55, el 16 de abril.

Una obra de arte es siempre una denuncia. No hablemos de protesta. La fotografía es ahora documento y es historia. Es el manifiesto de un momento. El instante fugaz que certifica un drama, eso es la fotografía. La belleza y la ternura también son drana, movimiento, expresión. Y cuando la imagen es arte, se convierte en testigo de cargo contra todos nosotros. Nos obliga a quitarnos el antifaz.

Valorada desde un ángulo inédito, la exposición fotográfica cle Eliú Vega nos demuestra hasta qué punto el pueblo muestro y todos los pueblos del llamado tercer mundo, viven instantes dramáticos que deben ser denunciados como documentos acusadores de la condición humana (?) en una sociedad de consumo donde la pobreza ha llegado a constituir un show, un espectáculo, curiosamente aplaudido por quienes tenemos la obligación de evitarlo. Pero el carnaval termina a los tres días.

Estos pueblos, de los que Eliú Vega está expresando sus necesidades y apremios, son pueblos de una dinámica sobrepujante. "El Juan Pueblo de México", captado aquí en sus momentos más punzantes, es un pueblo "que se mueve" a pesar del asesinato de Galileo, cuya lección histórica está sacudiendo la anclurosa comodidad del mundo. Galileo Galilei (asesinado en Italia en 1692).

Sergio Magaña

RODOLFO AGUIRRE TINOCO. Exposición de pintura psiquica y acuarelas, presentada por el Instituto de Arte de México, Puebla 141, del 16 de abril al 7 de mayo. 
Catálogo: 22 acuarelas tituladas en los albores de la creación, 3 acuarelas tituladas masa bestiaria, 3 dibujos titulados masa bestiaria, 8 acuarelas con títulos: metamorfosis, Dante, halo vital, espiritu y materia, el valle de los pensamientos, tiempo y espacio, génesis, los vigilantes del sol negro.

colectivs. Exposición presentada por el Instituto Cultural Hispano Mexicano, Tabasco 68, el 17 de abril. (Esta Exposición estará presentada en la III Bienal Internacional del Deporte en las Bellas Artes), en Barcelona, España del 17 de abril al 31 de mayo.

Nombre de los expositores: Chamizo, José Chávez, Javier Girón, Tomás Gonález Diaz, Daniel Manrique y Zukor.

IRENE beCERril. Exposición de óleos y dibujos, presentada por el Departiamento del Distrito Federal, Dirección General de Acción Cultural y Social, Galerías de la Ciudad de México en el Centro Social Popular "Leandro Valle", Av. Sur 8 y Oriente 241, Col. Agrícola Oriental, del 17 de abril al 8 de mayo.

JACI $\Lambda$ FRID. Exposición de artesanía, presentada por el Departamento del Distrito Federal, Dirección General de Acción Cultural y Social, Galerías de la Ciudad de México en el Centro Social Popular "Gral. Ignacio Zaragoza", Av. Oriente 154 y Calle Sur 121, Col. Escuadrón 201, del 17 de abril al 8 de mayo.

Datos biográficos de la Artista: Jacia Frid, nació en Berdichev, Ucrania, y llegó a México en 1928 para quedarse en el país definitivamente.

PEDro CORONel. Exposición de pinturas, presentada por la Galería de Arte Mexicano, Milán 18, del 19 de abril al 15 de mayo.

Minotauro Coronel. Detrás del Panteón tiene su madriguera o palomar mi amigo el Minotauro de Nueva España. No sé ya qué Ariadna o qué Malinche puso el hilo en mis manos del laberinto de escaleras que lleva al torreón donde está preso de sí mismo y embiste contra los muros blancos, los acuchilla a espátula, en camisa, descalzo y aún con sueño entre los ojos, aterrado de su blancura. Brotan chorros de vino de los odres acribillados a estocadas, fajas de algas, discos de papel, un trébol malva contra un sol magenta, un anillo de humo anaranjado sobre un verde de paño de billar.

Yo que naturalmente, llego armado de buenas intenciones a destruir al monstruo en su guarida, al coronar el último de los cien escalones y decir las últimas palabras que me abren los últimos recintos, me veo, espada en mano, desarmado por varias cuchilladas luminosas que me asestan los lienzos; miro ciego y los muros me deslumbran, me tienden, me abren, me alzan trampas súbitas, puertas falsas, espejos engañosos, vidrieras a la luna, ojos de buey al sol de los aztecas y un castillo de naipes transparentes.

Recorro toda la pirámide tras cruzar el océano a caballo, Teseo, Cortés, armado, inerme, y busco en vano al Minotauro por entre los despojos humeantes donde aún laten los siete corazones que acaba de arrancarle al mero sol. Poco a poco mis ojos se acostumbran a esta penumbra de colores, y en el hueco de una escalera, bajo el polvo de oro que lanza oblicuo el sol de una rendija, lo veo agazapado, con los ojos fijos en mí, vidriado, inmóvil, con el rostro encerrado en su máscara de obsidiana.

Ya estanos frente a frente. ¿Quién vencerá? ¿Tesco? ¿El Minotauro? Nos mira- 
mos buscándonos el punto flaco, el flanco vulnerable, la fracción de segundo de abandono, el desfallecimiento momentáneo. Los ojos en los ojos, fijos, duros, crispado el tacto y el oído alerta y el olfato latente y la saliva empeñada en el cielo de la boca. ¿Salta él? ¿Salto yo? La espada se damasquiria al sol, la máscara se patina a la sombra.

De repente los ojos amarillos recuerdan algo, brillan, se iluminan por dentro, reconocen, y una sonrisa hace saltar la máscara en cien pedazos. Siento un golpe y la hoja de mi espada se hace humo.

Ahora subimos otras escaleras, descalzo él, con la blusa anudada sobre el ombligo y todo lleno de salpicaduras multicolores de las víctimas de sus sacrificios murales.

Ahora subimos otras escaleras hasta el embarcadero del balcón que zarpa cada tarcle $\mathrm{y}$, juntos, hacemos un viaje por las cúpulas y por las copas de los pinos y por las azoteas florecidas, y con el sol poniente, que se exprime como inmensa naranja y baña el mundo, brindamos sin cesar por esta lucha que acaba apenas de empezar y que nos va a durar toda la vida.

\section{Aquilino Duque} Roma 31-VII-69

exiosición Pictórica. Presentada por el grupo Cuña, pintores de México en Homenaje a Lázaro Cárdenas, con la participación de la Dirección de la Esc. Sec. Nocturna "Presidente Cárdenas" ANEESHTAC, Sindicato Mexicano de Electricistas, Antonio Caso 43-45 del 20 al 30 de abril.

Hablar del grupo Cuña de pintores, grabadores y escultores de México, es resumir 30 años de difusión ininterrumpida de las artes plásticas entre los sectores de más escasos recursos económicos de nuestro pueblo. Sus maestros fundadores Jorge A. Corona y José Valeriano Maldonado, han recorrido muchos pueblos y ciudades de nuestro país, sembrando la semilla cultural por medio de exposiciones pictóricas o enseñando a los niños, a los jóvenes y a los adultos. No conozco otro grupo similar que haya tenido la constancia y la tenacidad para llevar su arte a las capas sociales que más necesitadas están de ver o practicar la pintura, el grabado o la escultura. Lograr que en un momento dado un obrero o un campesino, un bolerito o un estudiante, uula niña o una costurera agarren un pincel para dejar en un papel sus colores rudimentarios, es propósito del grupo $C u n ̃ a$, pues sabe que de esa manera lleva felicidad y esparcimiento, aunque sea temporalmente, y que además les dejan una mínima enseñanza que de otra forma nunca podrán adquirir dichas personas.

De esta obra cultural se deriva un ejemplo que deberían seguir todos los artistas plásticos que pretenden ocupar un lugar prominente en su rama y desde luego también los que lo han logrado. No deben olvidar que nuestras gentes más humildes poseen una gran sensibilidad para lo bello, para lo hermoso pero que desgraciadamente su pobreza social y económica los limitan a concurrir a centros especializados y a galerías de arte. $Y$ es aquí, precisamente, donde entra la labor de este ejemplar Grupo Cuña, que antepone al provecho personal de sus maestros, el deseo de enseñar, promover y difundir su obra artística, con las características de un gran sentido humano.

Como un ejemplo de lo que hemos expresado, es la exposición pictórica que inau- 
gurarán de inmediato, en el local del Sindicato Mexicano de Electricistas, los artistas de este grupo y a los cuales felicito sinceramente.

Prof. Raúl. Araico

Nombre de los expositores: Jorge A. Corona, José Val. Maldonado, Luis Alberto J. Rodriguez, María Herrera, José Francisco Vázquez, Ferido Castillo H. Miguel Aroche Parra, Bartolo Jiménez M., Gutenberg Rizero, Amol Argáiz Jamet, Martin Herrera, Rita Frías de Flores, Lilia Ortiz Zentelli, Josí Velueta $R$.

holanda. país y pueblo. Exposición presentada por el Departamento del Distrito Federal, Dirección General de Acción Ciltural y Social, Galerías de la Ciudad de México en el Centro Social Popular "José María Morelos y Pavón", Lago Trasimeno y Lago Erne, Col. Pensil, del 21 de abril al 8 de mayo.

FRED powedx. Exposición de esculturas, series mexicanas, los planetas, máquinas de girasoles, presentada por el Instituto Nacional de Bellas Artes, Sala Internacional Galerías del Palacio de Bellas Artes, el 21 de abril.

ÁNGei. boLIVer. Exposición de dibujos, presentada por el Departamento del Distrito Federal, Dirección General de Acción Cultural y Social, Galerías de la Ciudad de México en el Centro Social Popular "Aquiles Serdán”, Puerto Tampico número 4 esquina con Puerto Guaymas, ampliación de la Colonia Casas Alemán, del 22 de abril al 8 de mayo.

FFRnANio RAMOS l'RIDA. Exposición de óleos, grabados y tintas, presentada por el Instituto Nacional de Bellas Artes, Museo de Arte Moderno, Galería de exposiciones temporales, plinta baja, salas derecha e izquierda, el 22 de abril.

PEDRo coRones. Exposición de óleos, dibujos, acuarelas, presentada por la Galería de Arte Mexicano-Florencia, Florencia 35, el 23 de abril.

Ángli pichardo dávila. Exnosición de Chiapas, su selva, presentada por el Salón de la Plástica Mexicann, JNBA/S. E. P., Havre número 7, del 26 de abril al 17 de mayo.

JEsús tel.Los $A$. Exposición de óleos recientes, presentada por la Galería Arvil, Hamburgo $2+1$, del 26 de abril al 15 de mayo.

NiETo. Exposición presentada por el Instituto Anglo-Mexicano de Cultura, A. C., Antonio Caso número 127, el 27 de abril.

Datos biográficos: Rodolfo Nieto, nació en Oaxaca, en 1937.

vicente rojo. Exposición de 17 mevas pinturas, presentada por la Galería Juan Martín, Amberes 17, del 27 de abril al 15 de mayo. 
paulina trejo. Exposición presentada por el Salón de la Plástica Mexicana, INBA/ S.E. P., Havre número 7, del 29 de abril al 17 de mayo.

Flaviano E. CORAL-R. Exposición de obras de 1970-71, presentada por la Galería José Ma. Velasco, INBA/S. E. P./ Peralvillo 55, el 30 de abril.

exposición Cartel. generación 70. Presentada por la Escuela Nacional de Artes. Gráficas, Sala de exposiciones, Bucareli 117, el 30 de abril.

Nombre de los expositores: Carlos Esteve Diaz, Eleuterio Jiménez Almazán, Gonzalo Quczada Santamaría, Graciela Torres Barrón, Juan Manuel Sánchez Soto, Luis Castillo Vilchis, Ofelia D. González Brizuela, Ricardo López Pirez, Rodolfo Fuentes Meza, Rolando Cano Flores, Victor Mamel López Wario.

Amador Lugo. Exposición de 42 obras, presentada por el Gobierno del Estado de Nuevo León, INBA, Aramberri 504 pte., Monterrey, N. L.

Amador Lugo, nació en la ciudad de Taxco, Gro., México. Inició sus estudios en la escuela de Pintura al Aire Libre de su ciudad natal, que dirigía el maestro japonés Tamiji Kitagawa. En 1942 se traslada a la ciudad de México e inicia la carrera de maestro grabador en la Escuela de las Artes del Libro que dirigía el maestro Francisco Díaz de León. Asimisno, en la Escuela Normal Superior cursa la carrera de naestro de Artes Plásticas. En la Academia de San Carlos, ahora Escuela Nacional de Artes Plásticas, de la propia ciudad de México, asiste a las clases de grabado y modelado con los maestros Carlos Alvarado Lang y Julio Adeath. A partir de 1942 ha tomado parte en exposiciones colectivas tanto en México como en el extranjero. Ha realizado exposiciones personales en el Salón de la Plástica Mexicana dependiente del INBA y en la Galería de Arte Mexicano que dirige la señora Inés Amor. En el año de 1968 presentó una exposición en la ciudad de Chilpancingo y en Acapulco en donde dictó conferencias sobre el arte pictórico de México. Ha viajado a los Estados Unidos y a Centro América. Es fundadur de la Sociedad Mexicana de Grabadores y presidente en tres ocasiones de la propia organización. Le fue otorgada medalla de oro en las exposiciones de los maestros de Artes Plásticas que se realizan anualmente y patrocinan el Instituto $\mathrm{Na-}$ cional de Bellas Artes y el Sindicato Nacional de Trabajadores de la Educación. En tres ocasiones ha obtenido la beca anual que el INBA concede a los maestros en las exposiciones de concurso. Ha formado parte del Consejo del Salón de la Plástica Mexicana en dos ocasiones. También ha sido uniembro fundador de las organizaciones de artistas de México: SOCIEDAD PARA EL IMPULSO DE IAAS ARTES PLASTICAS $y$ en un principio del FRENTE NACIONAL DE ARTES PLASTICAS. Fue miembro del Comité de estas organizaciones en donde colaboró en diferentes puestos. Posteriormente formó parte de la ORGANIZACIÓN DE ARTISTAS, PINTORES, ESCULTORES Y GRABADORES junto con el arquitecto y pintor Juan O'Gorman y los pintores Jorge González Camarena, Francisco Eppens, Raúl Anguiano, Francisco Dosamantes y otros artistas. Actualmente, forma parte del grupo PAISAJISTAS DE MEXICO. Este grupo presentó su primera exposición en Septienbre de 1969 en la Sala Verde del Palacio de Bellas Artes. Ha colaborado en los cursos de arte vivo que organiza el Departamento de Difusión 
Cultural de la Universidad Nacional Autónoma de México. Imparte clases en la escuela Nacional de Artes Gráficas, donde cursó la carrera de grabado con anterioridad. Tanto en este plantel como en la Escuela Nacional de Educadoras ha impartido clases de dibujo y pintura e Historia General del Arte. Algunas de sus obras de pintura, grabado y dibujo se encuentran en colecciones de México y el el extranjero. El INBA la adquirido algumas de sus obras. Los museos de Brooklin y de Arte Moderno de Nueva York también han hecho adquisiciones de sus grabados y pinturas. En el mes de agosto de 1970, participó en la exposición de dibujos que se presentó elr el Salón de la Plástica Mexicana junto con el grupo de PAISAJISTAS. En abril del mismo año, junto con el grupo de PAISAJISTAS de MEXICO participa en la exposición, paisajes de Morelos, que se llevó a cabo en la ciudad de Cuernavaca en ocasión de la VII Feria de la Flor.

Catálogo: 1. símbolo y grandẽa del México prehispánico, óleo 2. desnudo, óleo 3. entrada a Tarco, óleo 4. valle de Mérico nimero 1, óleo 5. valle de Mírico nímero 2, óleo 6. arboleda, óleo 7. barco encallado, óleo 8. alrededores de Taxco, b́leo 9. paisaje urbano, óleo 10. montañas dc Taxco numero 1, óleo 11. montañas de Taxco nímero II, óleo 12. montañas de Taxco número $\mathrm{III}$, óleo 13 . montañas de Taxco número $I V$, dibujo 14 . cerro de Huisteco nimero $I$, óleo 15 . cerro del Huisteco número 11 , óleo 16. el Popocatépetl y el Iztaccíhuatl, óleo 17. los remedios, óleo 18. valle de Chalco, óleo 19. barcos en Isla Mujeres, óleo 20. nopales y montoñas, óleo 21. el Cerro del Chiquihute, óleo 22. Tepoztlán nuimcro I, óleo 23. Tepostlán número $I I$, óleo 24 . Tepostlán mincro $I I I$, óleo 25 . Tepostlán numero IV. óleo 26. Laguna de Bakalar, óleo 27 Puesta de sol en Pie do la Cuesta número $I$, acuarela 28. Puesta de sol cn Pic de la Cuesta número II, acuarela 29. Poza en Oaxtcpec, acuarela 30 . rincón en Oaxaca, acuarela 31. mariposa en vuelo, acrílico 32. explosión en el cspacio, acrílico 33. la tormenta, acrílico 34. en el espacio, acrílico 35. el mundo en llamas, acrílico 36. hanacas número $I$, acrílico y tinta 37. hamacas numcro $I I$, acrílico y tinta 38 . cncmiado nimero 1 , acrílico y tinta 39. cncruado numero II, acrílico y tinta 40. desde la cima, dibujo 41. hombres empujando una alcantarilla, dibujo 42, pantén y montañas, dibujo.

ERASTo cortés JuÁREz. Exposición Homenaje, presentada por la Galería Municipal, F. Ramírez Osorio, Plazuela de Los Sapos número 6 Sur 503, Puebla, Pue.

Datos biográficos del artista: Erasto Cortés Juárez, nació el 26 de agosto de 1900 en Tepeaca, Edo. de Puebla. Ingresó a la Academia de San Carlos (Escuela Nacional de Artes Plásticas), el año de 1916. En 1922 estudió como su último año en 1a Escuela de Pintura al aire libre, en Coyoacán, D. F. En 1923 ingresa como maestro de dibujo en las escuelas primarias dependientes de la Secretaría de Educación Pública. En 1946 maestro titular de dibujo de $1^{\circ}$ y $2^{\circ}$ años, en la Escuela Nacional de Artes Plásticas hasta 1956 que fue cuando se pensionó. De 1947 a 1956 maestro de dibujo en la Escuela de Pintura y Escultura, dependiente del Instituto Nacional de Bellas Artes. En 1948 comienza a grabar, considerado como autodidacta. En 1950 se edita su plaqueta "fisonomías de animales", con 40 grabados originales y respectivos textos que él mismo escribió. En 1951 su segunda obra titulada "el grabado contemporáneo". En 1960 su tercera obra titulada "héroes de la Patria", con 36 textos biográficos y respectivas efigies en grabado. Esta obra se la editó la Universidad Nacional Autónoma de México. En 1967, se editó en San Miguel de Allen- 
de, el Calendario Histórico Guanajuateıse. Rccopilación de 1,000 fichas y 20 grabados ilustrativos. Prepara actualmente la "listoria del grabado en México". Ha escrito numerosos artículos sobre Artes Plásticas y asuntos de Historia de México. Colaboraciones en diversas revistas y periódicos tanto de la capital como de la provincia. Fundador y Subdirector Técnico del Centro Cultural "Ignacio Ramírez", ubicado en San Miguel de Allende, estado de Guanajuato. Creó varios talleres de Artes Plásticas. En la misma población guanajuatense presidente de la corresponsalía del Seminario de Cultura Mexicana. Organizó exposiciones de artes plásticas, un jardín del arte, un cine-club y diversos conciertos y conferencias. Ha participado en iumerosas exposiciones colectivas de grabado y varias individuales, tanto en la ciudad de México, en los estados y en el extranjero. El Museo de Arte Moderip de Nueva York, el Instituto Nacional de Bellas Artes, la Sociedad de Grabadores Suizos, tienen en sus colecciones varios de sus grabados. A partir de 1951 miembro activo de la Sociedad Mexicana de Grabadores. De 1951 a 1953 miembro activo del taller de Gráfica Popular. De 1954 a 1960 miembro activo de la Asociación Mexicana de Críticos de Arte. A partir de 1970 Miembro titular y de número de la Acadenia de Artes. En octubre de 1970 se llevó a efecto en la Sala Verde del Palacio de Bellas Artes su exposición retrospectiva de grabado, con motivo del acto recepcional como miembro de la citada academia.

Diversos y valiosos han sido los méritos demostrados en el ámbito del grabado para que Erasto Cortés Juárez venga a formar parte, en calidad de Miembro titular y de número, de la Academia de Artes. Débense al aprecio de sus trabajos de grabador, como los que realiza en la investigación y divulgación de todo cuanto se refiere a la tónica o historia de este arte en nuestro país... Las técnicas de grabado que cultiva Cortés Juárez, en los procedimientos en relieve comprenden: el linóleo y las maderas de hilo y de pie, con predominio del que mencionó en primer término, mismo que le ha respondido sin esa blandura y docilidad que suele ser común cuando se mplea este material. Los trabajos de Erasto, cuando emplea el linóleo, diríase que provienen de planchas de madera por la respuesta de los instrumentos, como se manifiesta en las tiernas estampas de su 'Fisonomías de animales.

Francisco Díaz de Léón

Artista cuya actividad se ha extendido a diversos campos; ha fundado y participado en el establecimiento de Sociedades para el impulso de las artes plásticas y del libro mexicano. Como escritor e ilustrador ha colaborado en distintos diarios $y$ revistas del país; fue miembro activo del famoso Taller de Gráfica Popular y lo es del Salón de la Plástica Mexicana, del Instituto Nacional de Bellas Artes y ie la Asociación Mexicana de Críticos de Arte. Erasto Cortés Juárez se ha distinguido como historiador y crítico de arte, ya que no podría separarse una función de la otra.

Hay que recordar el momento en que inició sus estudios y el impacto que debió dejarle la Escuela de pintura al aire libre, patente en varios de sus grabados. En conclusión diré que la obra de grabado de Cortés Juárez tiene distinción y cierto encanto que proviene de su fino espíritu, de su ponderación y capacidad expresiva, 
de manera que es, sin duda, uno de los grabadores mexicanos del sigho que liene un sitio en la historia de nuestro arte moderno.

Justino Firknániez

Hombre tenaz y optimista la probado con éxito su curiosidad y sus incesantes anhelos de estudios y de renovación, no sólo en el grabado, su principal medio de expresión, sino en glosas y criticas en periódicos, libros y álbumes en que alternan sus estampas con textos relacionados con los conceptos. Su curricuhm vitae es amplio y rico. Al lado de los premios recibirlos figuran testinonios de sus exposiciones, así como de su participación en sociedades y grupos de artistas, pues siempre le la distinguido un espíritu de colaboración y convivialidad, enteramente espontáneo y sincero... La exposición retrospectiva de su obra abierta en el Palacio de Bellas Artes conmemora su entrada a la Academia de Artes, en la que sustituye a Leopoldo Méndez, recientenente fallecido... Visitándola queda afirmarla su versatilidad y el carácter propio de sı técnica, así como la gran variedad de los temas.

Jorge Juan Crespo de: la Sierna

Catálogo: 1. mi madre, linóleo 2. vendedoras oaxaqueñas, linóleo 3. aguadores de Tepeaca, Pue., linóleo 4. mujer de Jicalán, Mich, linóleo 5. tubero de Colima, madera de pie 6. platanar de Uruapan, Mich., linóleo 7. paisaje de Juchitán, linóleo 8. expropiación petrolera, linóleo 9. Cerro dcl Mucrto, Sin., madera de hilo 10. fecundidad, madera de pie 11. Fuensanta, madera de pie 12. redes, madera de pie 13. tirada fruta en Juchitán, Oa... linóleo 14. irrigación, linóleo 15. calle de Uruapan, linóleo 16. Casas de Pescadores, madera de pic 17. el hambreador, linóleo 18. la civilización contra la guerra, linóleo 19. troje morclense, linóleo 20. mercado de Pucrto l'rincipe, Haiti, linóleo 21. casas de Puerto Príncipe, Haití, linóleo 22. portada 1951, Tlacotalfan, linóleo 23. barrio del nraiz, San Míguel de Allende, linóleo 24. San José de la Montaña, San Miguel de Allende, linóleo 25. minas del obraje, San Miguel de Allende, linóleo 26. acueducto de los Remedios, Méx., linóleo 27. músicos de Atotonilco, Gto., linóleo 28. obras de drenaje, linóleo 29. ranchería sinaloense, linólco 30. chosa sinaloense, linóleo 31. Cuantímoc, linóleo 32. Miguel Hidalgo y Costilla, linóleo 33. José Maria Morelos y Pavón, linóleo 34. Ignacio López Rayón, linóleo 35. Benito Juárez, linóleo 36. Ignacio Zaragoza, linóleo 37. Jesús González Ortega, linóleo 38. Ignacio Ramírez "El Niaromante', linóleo 39. Sor Juana Inés de la Cruz, linóleo 40. Francisco Javior Clavijero, linóleo 41. Manucl Orozco y Berra, linóleo 42. Ramón López Velarde, linóleo 43. Amado Nervo, linóleo 44. Manuel José Othón, linólco 45. José María Velasco, linóleo 46. Dr. Atl, linóleo 47. Hermenegildo Bustos, linólco 48. Diego Rivcra, linóleo 49. Francisco Goitia, linólco, tinta china 50. el río 51. casas viejas 52. calle de San Miguel de Allende 53. al 61. animalitos 62. al 70 . animalitos (linóleos).

heriberto JUÁREz y adRÍ́N bRUM. Exposiciones de esculturas y pinturas, presentadas por la Fundación Cultural Miguel Cabrera, Calle García Vigil, número 818 (Los Arquitos), Oaxaca, Oax. y por la cortesía de supermercado "Iris", calzada Porfirio Diaz número 150 en Oaxaca.

Heriberto Juárez (escultor). La obra de Feriberto Juárez es tan peculiar, tan 
extraña, que de inmediato se piensa en el autor. ¿Quién realiza estos seres mitad oníricos, mitad teratológicos? ¿cómo es él? ¿qué piensa, qué hace, qué desea? Después de ver su obra se supone que en el cultor hay algo más que en sus cultivos, pues al hacedor siempre quedan creaturas en perspectivas. Esto no es común. Con frecuencia la obra artística es un poco nitológica y otro tanto realidad. La relación directa es llana y simple; se sabe que un objeto de arte ha sido hecho por un ser humano y se supone que ese ser es como los demás; pero la parte extraña de esa obra sugiere procedencias poco comunes; ese algo indefinible que le desprende de lo cotidiano; ese toque de horror o de gracia que el observador cree hallar en algunas creaciones de la plástica, no parecen ser un fruto habitual del hombre y es esto lo que induce en la tentación de conocer al artista y saber de qué padre proceden tales creaturas.

Es condición del buen artista contar con lenguaje para expresar lo que elucubra su inventiva, lo que dicta la emoción. Juárez tiene numerosas soluciones y variados recursos; por igual puede afrontar expresiones realistas o académicas, que interpretaciones figurativas o volúmenes de expresión abstracta, lo mismo es hábil en el manejo de materiales pétreos (granito, cantera, mármol, basaltos) que en maderas, plásticos y metales; usa con fluidez materias únicas o procedinientos mixtos; él mismo da sus pátinas y diseña o labra sus plintos, bases o pedestales. Pero lo más importante en materia de ejecución, es el haber eliminado dos tiempos del sistema tradicional de fundición conocido como procedimiento de la "cera perdida"; primero, el modelado en arcilla o substitutos y segundo, el moldeo del original para obtener la cera. Puedo equivocarme, pero para mí, este joven artista ha creado un nuevo procedimiento que parte de la cera y consigna directamente en ella y no por 1ráslado, texturas y datos que la convierten en original. De allí en adelante, el procedimiento de picadizos, coadas, quemas y fundidos, son los liabituales.

Debo aclarar que tal procedimiento le ha llevado a cicrta preferencia por la niniescultura que, de no tener en él tan vigorosas, crudas y sorprenclentes expresiones, podría haberse quedado en el bibelotismo y la decoración. Esta tendencia deriva del procedimiento y no del escultor; él gustó de realizar también obras de grandes dimensiones, pero prefiere los bronces de proporción controlable; en ellos ha encontrado su verdadero idioma plástico.

Tiene este artista predilección por las formas expresivas de la tristeza y la meditación, el ritmo y ha alegría; hay en las creaturas de sus correrias fantásticas, algo premonitorio sobre seres de otra latitud cósnica o formas que corresponclen al mundo subjetivo, a la pasión y el tormento o a la gracia y la dulzura. De su taller van escapando sujetos complicados y alucinantes. $Y$ de pronto sus figuras desembocan en una fauna extraña de toros, caballos y animales fantásticos. El astado se multiplica en sus colecciones. Ello tal vez se inspira en influencias o recuerdos de sus días taurinos, cuando iba por las tientas y los cosos tratando de coronarse diestro de la tauronaquia y recibir ovaciones de los públicos. Heribcrto Juárez fue novillero. Luego empezó a modelar cornúpedos de lidia, siguiendo las huellas de Albarrán y de Benjour y de pronto pasó a lia zona de las tentaciones y las pesadillas y los sueños. Desde entonces, con los dedos en la cera o con el cincel y la gradina en las manos, ha viajado por diversos niveles de la inaginación.

Su producción es audaz y moderna, la mayoría de sus creaciones van del surrealismo a la abstracción. Tienen una personalidad propia, potente y reveladora. No. 
pertenece a camarillas; no debe su posición en la plástica de México a la protección de las mafias o a la exaltación de críticos lanzagenios, ni al favor de mecenas o promotores. Todo lo ha hecho con imaginación, talento y constancia. No pertenece al mundo de los autopublicistas, ni al de los megalómanos pedantes; es hombre valioso y sencillo. Pero tampoco es enemigo de tendencias, no polemista de estilos. Sus argumentos están en su obra y total. Se lleva bien con los soberbios y ellos no le hostilizan. Respeta a todos; goza con el triunfo de los demás, aun de los opuestos a su tendencia artística. No es patricida, ni combatiente; es artisia. Es incansable, novedoso, inquieto, brillante. No lo dice él, sino su obra. No le interesa que le elogien, pero no le desagrada. Es fuertemente mexicano, en su ser y su conducta, vigorosamente cosmopolita y universal en su obra. $Y$ esto explica que su obra figure en importantes museos extranjeros y valiosas colecciones nacionales. Está al día en los sucesos del arte, pero es un hombre solitario y feliz. Recluido en su desordenado paraíso de plasmas inconclusos y seres planetarios, o rliscurriendo por la soledad con las manos en los bolsillos silbando y mirando la noche que reina afuera o a la claridad crece adentro, no exige ni reclama; sueña y trabaja. Su vida es la poesía de la humildad y del empeño; y si la luz avanza a él, es por la propia dinámica del merecimiento.

Le he dedicado esta nota recordando su maravillosa producción y la generosidad con que divulga cuanto sabe, seguro de que el talento y la sensibilidad no se gastan al transmitirse ni se mancillan al propagarse.

Cierro estas palabras. Que justo y ancho sea el canino que le espera y que se mantenga siempre rico en tareas, nuevo en inventivas y limpio de vanidades.

Miguel Álvarez Acosta

\section{MAYO}

TZIPORA Ronen. Exposición de técnica mixta, presentada por el Conité de Actividades Generales, en su XXIII Aniversario de La Independencia del Estado de Israel, Galerías C. D. I., Av. Manuel Avila Camacho 620, el $1^{\circ}$ de mayo.

GUSTavo ARIas MURUeta. Exposición "Suite Erótica" (portafolio de grabados-intaglio y dibujos relacionados), presentada por el Instituto Cultural Mexicano Israelí, A. C., Río Túber $\mathrm{N}^{9} 12$, del 4 al 18 de mayo.

chappie angulo. Exposición presentada por el Museo de las Culturas, INAH, S. E. P., Moneda 13, el 4 de mayo.

lılo LEONI. Exposición de esculturas en madera, presentada por la Galería MerKup, Molière N? 328-C, el 4 de mayo.

IMÁGenes de Pastrana. Exposición presentada por el Instituto Francés de América Latina, Nazas 43, el 4 de mayo. 
baruj salinas. Exposición de óleos recientes, presentada por la Galería Mer-Kup, Molière 328-C, el 4 de mayo.

Datos biográficos: Baruj Salinas nació en La Habana, Cuba, en 1935. Educación: graduado en arquitectura en la Universidad de Kent, Ohio, E. U. A.

colectiva, i.a figura. Exposición presentada por la Plástica de México, Londres 139 , el 6 de mayo.

TAdeusz LApinski. Exposición de litografías, presentada por el Instituto Mexicano Norteamericano de Relaciones Culturales, A. C., Galería Nabor Carrillo, Hamburgo 115 , el 6 de mayo.

Datos Biográficos: Tadeusz Lapinsky, nació en Rawa, Polonia en 1928, y es hoy ciudadano norteamericano. Estudió en la Academia de Varsovia en 1949 y recibió su maestría en 1955. Vive y trabaja en la ciudad de Nueva York desde 1968.

guillermo téllez. Exposición de dibujos, presentada por la Escuela Nacional de Artes Plásticas, Academia 22, del 7 al 20 de mayo.

Akiniko nagata. Exposición de cerámica stonezare, presentada por la Escuela Nacional de Artes Plásticas, Academia 22, del 7 al 16 de mayo.

Datos biográficos: Akihiko Nagata nació en el año de 1943. Hizo sus estudios de arte en la Universidad de Tokio de 1963 a 1969, habiendo obtenido la Maestría en Cerámica. Llegó a México a principios de 1970, ingresando al taller de Graziella Díaz de León y de Loisa Reynoso, pasando después a ser un colaborador del Taller Experimental de Cerámica a cargo de Alberto Díaz de Cossío.

eXposición final del primer ciclo de talleres sabatinos 1971. Exposición de los trabajos elaborados, presentada por el Museo de las Culturas INAH, S. E. P., Moneda 13 , el 8 de mayo.

tomás parra. Exposición presentada por la Galería Pecanins, Hamburgo 103, el 11 de nayo.

Mabel-babellino-eiscar. Exposición de esculturas, presentada por la Galería Chapultepec, Insurgentes Sur Ne 11 bis, el 11 de mayo.

Datos biográficos de la artista: Mabel Eiscar, nació en Montevideo, Uruguay. Estudios: Escuela Nacional de Bellas Artes, Montevideo y Cerámica en la Escuela "Otto Kreuzer" de Buenos Aires.

nancy van o verveldt. Exposición de óleos, presentada por la Galería Cliapultepec, INBA, Insurgentes Sur $N^{0} 11$ bis, el 11 de mayo.

Datos biográficos: Nancy van O Verveldt, nace en La Haya, Holanda, vive en México desde 1952 con nacionalidad mexicana. Estudios en la Academia de Bellas Artes en La Haya, Holanda, y en Francia.

MAXINe wishnick. Exposición de obras, presentada por la Galería Chapultepec, Insurgentes Sur $\mathrm{N}^{0} 11$ bis, el 11 de mayo.

Datos biográficos: Maxine Wishnick, nace en Chicago, U. S. A. Estudia pintura y escultura en el Instituto de Arte de Chicago, Illinois. 
Exposición DE ARTE moderno DE BÉlgica. Exposición presentada por el Instituto Nacional de Bellas Artes, Secretaría de Relaciones Exteriores, Embajada de Bélgica, Museo de Arte Moderno, Galería de Exposiciones Temporales, el 11 de mayo.

Hacer una selección dentro del potencial artístico y plástico de un país, supone elegir a algunos artistas que por su obra y personalidad representan las tendencias vitales características del arte nacional durante determinado periodo de tiempo o en momento dado.

La selección hecha para esta exposición abarca el periodo posterior a la Segunda Guerra Mundial, de 1945 hasta 1970, años de particular agitación, con estilos y técnicas en evolución acelerada enmarcados, cada vez más, en la evolinción general de Europa y Norteamérica. Al igual que en otras partes, el carácter nacional cedió ante las presiones de una toma de conciencia universal, y el hombre, figura central en las perturbaciones mundiales y los acontecimientos actuales: políticos, religiosos, econónicos o sociales, se libertó de la obsesión limitativa de sus fronteras. Sin embargo, nuestras generaciones -y tal vez las nuestras sean las últimas- siguen condicionadas todavía por un determinado temperamento local, que en unos explican la fuerza de un color y el lirismo de un gesto, y e11 otros lo cerebral de una visión surrealista.

Los artistas presentados aquí fueron seleccionados por ser representativos de las diversas tendencias actuales: otros habrian podido representarlas también, pero se imponía un límite numérico.

Después de 1a Segunda Guerra Mundial, el arte belga conservaba todavía muchos elementos de la tradición plástica anterior a 1940. El expresionisno físico, que Laethem St. Martín vio evolucionar, impone su lirismo y su poder matcrial, y los integrantes belgas del movimiento "Cobra" extrajeron de él la autenticidad del gesto y el rico material no figurativo, mientras ciertas formas de la abstracción lírica revivieron, con sus diseños y manchas, la sensualidad de un color y la voluptuosidad de una línea. El surrealismo prosigue su carrera literaria, fautástica y, a veces, lúdica, y accede, al través de la figura de René Magritte, a cierta forma rueva de representación, en la cual el aislamiento de un objeto, de una forma o de una figura, añade una nueva significación a la imagen. Finalmente, la estructuración y lá construcción, tales como se propagaban en los años veinte, renacen en formas geométricas y efectos ópticos de pura abstracción. No importa la tendencia, sin embargo, mientras la preocupación plástica y el poder cromático sigan siendo los denominadores comunes.

El lirisno expresivo en la estirpe de "Cobra" compromete al hombre y la raturaleza. Pierre Alechinsliy interroga las superficies inquietantes del papel o de la tela. Sigue la vida de las tintas y comparte la alegría de sus campos coloridos. Agrega una fuerza dramática a los signos que se metamorfosean en formas polivalentes. Una pura apariencia ambigua anima el clima de Serge Vandercam, quien lleva la abstracción a veces muy lejos para intensificar la fuerza sugestiva. El signo con Vandercam se vuelve una herida. En cambio, no existe la nenor sombra de llaga en las esculturas de Reinhoud, en las cuales la ficción y el humor frecuentemente se igualan. Como Alechinsky, Reinhoud lleva la vida hasta las rcgiones más profundas, donde pululan los insectos y donde nacen del metal flores fabulosas.

Félix Roulin, más joven, quien no se ha comprometido todavía con ninguna tendencia, busca esa misma naturaleza pero en estado virgen. Moldea, a lo vivo, manos, 
puños, dedos, bocas y senos, transförmándolos en clementos de referencia que dan vida a una masa abstracta. La dualidad de la prescncia humana y el material vuelven a poner en duda esa física que traduce la idea general de lo humano y que, confrontado con las balas y los fusiles, opone la carne viva a la máquina mortíflera. Más donde hay humanidad hay un signo, y donde Alechinsky expresa la vida por medio de una escritura con tinta, otros artistas dibujan los suyos bajo el mandato del espíritu o de la materia.

El carbón proporciona a Lismonde un lenguaje vibrante, cuyos signos se extienden ante la vista a la manera de una exploración del mundo interior, como una búsqueda de límites propios. Los arcos y las arcadas se abren sobre profundidades no sospechadas mientras las superficies callan.

Descendientes de un expresionismo material, los "blasones solares" de Bram Bogart representan su alfabeto primordial del mundo, señales espaciales o estructuras elementales que condicionan el medio ambiente. Sis formas y sus colores simplifican la realidad al traducirla.

Una señal es también una toma de posesión del espacio y ese espacio, en la concepción estética que nuestros artistas tienen del arte, se vuelve elemento primordial al cual el ojo reacciona espontáneamente. Los Moving Signals de Hugo de Clercc, lo mismo que sus telas de signos gigantescos, se crearon en función de las perspectivas urbanas y arquitectónicas. El arte se vuelve anónimo; sólo cuentan la concepción y la visión.

En cuanto a Jan van den Abbeel y Willy Plompen, la verdad del mañana es el medio ambiente creado por un grupo de arquitectos, artistas, sociólogos, psicólogos, biólogos. E1 arte de Van den Abbeel, manteniéndose dentro de las dos dimensiones, se construye a menudo sobre 36 cuadros, produciendo efectos ópticos que invitan al espectador a participar en lugar de meramente contemplar. Plompen, menos agresivo, más tranquilo, recurre a ritmos más lentos, pero parte de la misma idea acerca de la sugestión espacial.

Otros ritmos en el espacio lo constituyen las telas cromáticas de Jef Verheyen cuyas gradaciones de color alcanzan, por su fuerza óptica, una inmaterialidad desprovista de nociones de distancia y espacio. Se inscriben en el espacialismo italiano de un Manzoni o de Fontana. Mas no sólo el ojo está solicitado en esa exploración del espacio, sino también el espíritu y, correlativa a la dicción The Responsive Eye, podríamos introducir la de Responsive Mind cuando Pol Bury construye en el espacio sus esculturas de planos móviles, que renuevan sin cesar la composición. Esa desmistificación de nuestra quietud que se emparenta con cierto espíritu surrealista influyó mucho a Pol Bury en sus principios, espíritı que siguió influyéndolo cuando se adhirió a "Cobra".

En cambio, las obras de Jacques Lacomblez y Jacques Chemay, que pertenecen plenamente a ese surrealismo de la posguerra, no ostentan, en absoluto, la misma noción del espacio y del color. Manteniéndose en la tradición ortodoxa de lá técnica clásica, sus obras destacan por lo excelente de la factura. En el caso de Lacomblez, la forma es cerebral, como reflejada en un espejo y pertenece al dominio del conocimiento espiritual -fragmentos de una "noche mineral". El surrealismo de Chetnay es dinámico y el dibujo de las formas da vida al espacio, recordándonos en su vegetación cósnica, la inquietud y la duda de un Matta.

Sí, por otra parte, el ejemplo de Magritte inquietó las primeras obras de Marcel 
Broodthaers, este artista rápidamente se declaró por vencido ante el movimiento desafiante de la nueva figuración. Por la imagen y el verbo, atenta contra las normas oficiales y los valores burgueses. Quién sabe si la reivindicición del Museo de Arte Moderno - Departamento de las Aguilas- es más auténtica o menos auténtica que su obra ostentada bajo la forma de mejillones o de frascos.

El pop art de Broodthaers es un pop urbano, mientras la obra de los pintores Raveel, de Keyser y Elías es un pop más cercano a la naturaleza, un folklore del terruño.

Después de colaborar en la decoración de los sótanos del Castillo de Beerveld, su evolución individual separó a esos artistas. Roger Raveel se volvió cada vez más hacia la tierra y naturaleza. La aparente torpeza de su estilo se escribe dentro de la sana tradición del campesino; lo fantástico de lo cotidiano y el misterio de lo ordinario le son familiares y aparecen en una simple porción de pared, una cara humana y sobre todo, un simple cuadro vacío.

En cambio, el estilo de Raoul De Keyser se vuelve cada vez nenos anecdótico y más y más pictórico. Con sus planos sobrios, de colores fuertes, tiende hacia lo abstracto. Evoca un mundo fascinante de cosas sencillas, tan humano en su ingente fuerza pictórica.

Etienne Elias, en fin, contempla, sobre todo, las relaciones entre el hombre, el objeto y el mundo. Su tema es banal, conformista, y tan real que recuerda la iconografía de Magritte. Más alejado de la naturaleza que Raveel, las intenciones de Elías son más sociales: traduce los medios burgueses, y los coloca con humor.

Pierre Lahaut también entabla el diálogo secreto entre el hombre y el objeto, pero entrecortado por largos silencios que permiten admirar la esencia misma de la imagen. No se puede decir que Paul Mara esté contemplando, sino que observa el movimiento y el ritmo de nuestro siglo, y confiere valores renovados a la figura $y$ al paisaje, gracias a su visión contenporánea. La publicidad, los medios masivos de comunicación, los sitios urbanos y su tránsito le sirven de evocaciones, que él sugiere por el trazo exacto del lápiz en medio de sus colores.

No podríamos concluir mejor este resumen sino echando mano de dos aspectos actualísimos de nuestro arte. Por un lado está la condición humana, puesta al desnudo por el dibujo de tipo "tira cómica", sencillo, singular, de Jean-Michel Folon, el profeta que pone en guardia contra la soledad y la desesperación, y que cuenta la bella historia de que algún día habrán un espacio verde y un cielo azul. $\mathrm{Y}$ por el otro, el espíritu lúdico de Panamarenko quien, por el mito de su nombre alimenta una leyenda, descubre el objeto construido como prototipo y llena el cielo de máquinas fantásticas, de las que nadie puede decir si volarán algún día. No sólo en sus esculturas sino también en su arte conceptual, la intensa poesía sobrepasa, con mucho, al estetisno violentado del nuevo folklore.

Phre Mertens

Cuando contemplamos el panorama del arte universal y particularmente cuando fijamos nuestra atención en el extraordinario fenómeno plástico-estético que conocemos como Escuela Flamenca, viencen a nuestra imaginación las figuras más destacadas de su cultura y no podemos pasar por alto las aportaciones que han dado al 
arte de todos los tiempos. Grandes paisajistas e intérpretes emocionados de un humanismo pictórico, han reiterado un sentimiento, una forma de expresar y representar seres y cosas, tomadas unas veces de la realidad circundante y otras, retrotraidas del mundo maravilloso de la fantasía. Obviamente no es necesario mencionar nombres que son ya del conocimiento general y que constituyen un espléndido legado a la humanidad.

Motiva este comentario la exposición que el Gobierno de Bélgica ha enviado a nuestro país como un acto de fraternal amistad, como un puente espiritual que contribuye no sólo a estrechar las relaciones de dos pueblos, sino también, a incrementar el mutuo conocimiento por medio del arte y la cultura.

Justo es considerar las dificultades que presenta el llevar a cabo una selección de los artistas que dentro de la gran producción contemporánea, debían de representar a Bélgica en esta muestra necesariamente limitada y en la que sin pretender agotar el tema, sí se brinda la oportunidad de ver de cerca obras que pertenecen a grupos destacados internacionalmente con su participación en las corrientes de más significación en el campo de la plástica actual.

Surrealismo, espacialismo, la pintura del signo, la abstracción, el arte "pop", el arte "objeto", son enunciados y representados en la Exposición Belga por la obra de sus pintores y escultores, que confrontan no sólo las inquietudes y las luchas del artista de nuestro tiempo, sino también la búsqueda incesante de una verdad inalcanzable.

Fenómeno semejante se produce en el arte mexicano y es por ello que no nos son ajenos, ni sus anhelos ni esperanzas, como tampoco lo es esa angustia renovada por crear un nuevo mundo de formas y de espacios. Un mundo mejor también para el hombre, cuya presencia está visible y latente ell todas y cada una de sus manifestaciones cualesquicra que éstas sean, como testimonio que son de su paso en el devenir infinito del tiempo.

\section{Miguel Bueno}

Datos biográficos de los artistas: Pierre Alechinsky, nació en Bruselas, el 19 de octubre de 1927. Bram Bogart, nació en Delft, el año de 1921. Marcel Broodthaers, nación en Eruselas, el año de 1924. Pol Bury, nació el 26 de abril de 1926. Jacques Chemay, nació en Gante, en 1938. Hugo de Clercq, nació en Gante, el año de 1930. Raoul de Keyser, nació en Deinze, en 1930. Etienne Elías, nació en Ostende, el año de 1936. Jean-Michel Folon, nació en Bruselas, en 1934. Jacques Lacomblez, nació en Bruselas, en 1934. Pierre Lahaut, nació en Brusclas, en 1931. Lismonde, nació en Bruselas, en 1908. Pol Mara, nació en Amberes, en 1920. Panamarenko, nació en Amberes, en 1940. Willy Plompen, nació en Gante, en 1943. Roger Raveel nació en Machelen aan de Leie, en 1921. Reinhoud, nació en Grammont, en 1928. Félix Roulin, nació en Dinant, en 1931, Van den Abbeel, nació en 1943, en Denderbelle Serge Vandercam, nació en Copentrague, en 1924. Jef Verheyen, nació en Amberes, en 1932.

Catálogo: 1. erupción vulcanológica de una idca azul, 1970, acrílico/papel "marufle" 100.5 x .53, col. Museos Reales de Bellas Artes de Bélgica 2. Central Park, 1965, 
acrílico/tela, $160 \times 293$, col. particular 3. cobra vivo, 1966, tinta, $152 \times 250$, col. particular 4. amarillo vertical, 1968 , técnica mixta $160 \times 165$, pertenece a Bram Bogart 5. blanco y rojo, 1969 , técnica mixta $200 \times 160$, pertenece al artista 6 . negro-azul-ncgro, 1970, técnica mixta $153 \times 160$, pertenece al artista. 7. museo de las águilas, $193 \times 158$, col. Estado Belga 8. sin título, $125 \times 85$, col. particular 9. puntuación s/f, madera y nylon, $100 \times 100$, col. Musco del Arte Walón, Lieja 10. escultura, 1967, madera de encino, escultura móvil, 225 x 80 × 20, col. Estado belga 11. Hashish, 1968, acrílico/tela $100 \times 80$, col. Stephane Janssen, La Hulpe 12. a orillas del estanque, 1969 , acrílico/tela, $100 \times 80$, col. Stepliane Janssen, La Hulpe 13. sin título, 1969, acrílico/tela, $100 \times 80$, col. Stephane Janssen, La Hulpe 14. Tubcless, 1971, óleo/tela, $150 \times 150$, pertenece al artista 15. Sakuski, 1971, óleo/ tela $200 \times 150$ pertenece a Hugo de Clercq 16. Nanan, 1971, óleo/tela, $150 \times 150$, pertenece al artista 17. afueras de gampelaere, 1967 , acrílico/tela $120 \times 150$, col. $\mathrm{K}$. J. Geirlandi, Gante 18. Squadra, 1968, acrílico/tela, $120 \times 150$, col. G. Joly, Eeklo 19. pensar en Charles Ives, 1969 , acrílico/tela, $120 \times 75$, pertenece al artista 20. love, 1970, óleo/tela, $20 \times 25$, col. K. J. Geirlandt, Gante 21. happy, 1970, óleo/tela, $20 \mathrm{x}$ 25 , col. W. De Clercq, Gante 22. hippy Elías, 1970 , óleo/tela, $20 \times 25$, col. Museo de Bellas Artes, Gante 23. autopista, 1970, serigrafía/aluminio, $60 \times 80$, pertenece al artista 24. la jungla de las ciudades, 1970, serigrafia/aluminio, $60 \times 80$, pertenece al artista Jean-Michel Folon 25. cualquier dircción, 1970, serigrafía/aluminio, $60 \times 80$, pertenece al artista 26. los peñones de la larga mucrte, 1962, óleo/tela, $97 \times 130$, col. Galería Arcanes, Bruselas 27. elegía para un jardin difunto, 1965, óleo/tela, $100 \times 81$, col. Galería Arcanes, Bruselas 28. Hanblechcyapi, 1967, óleo/ tela, 116 x 89, col. Galería Arcanes, Bruselas 29. Some flowcrs 2, 1958, óleo s/tela, $195 \times 146$, pertencce al artista 30. memorial flowers 2, 1968 , ólco/tela, $162 \times 162$, pertenece a1 artista 31. memorial 3, 1968, óleo/tela, $260 \times 116$, pertenece al artista 32. las perspectivas sincopadas 1, 1971, carbón/papel de arroz "maruflé"/panel $65 \mathrm{x}$ 50, pertenece al artista 33. Las perspectivas sincopadas II, 1971, carbón/papel de arroz "maruflé"/panel, $65 \times 50$, pertenece a Lismonde 34. las perspectivas sincopadas III, 1971, carbón s/papel de arroz "marufle"/panel, $65 \times 50$, col. Lisinonde 35. private Gardens, 1971, óleo/tela, $162 \times 162$, pertenece al artista 36. strings and other strings, 1971, óleo/tela, $162 \times 162$, pertenece al artista 37 . girl refusing to be a sculpture, 1971, óleo/tela, $162 \times 162$, pertenece al artista 38. acelerador 20, dibujo, $35 \times 55$, pertenece al artista 39. acelerador neumático 21 , dibujo, $35 \times 55$, pertenece al artista 40 . acelerador netmático 22, dibujo, $35 \times 55$, pertenece al artista 41. untitled, 1970, sillsscreen/tela, $320 \times 320$, pertenece al artista 42 . ante la parcd de hormigón, óleo/tela: 3 paneles, $145 \times 114,145 \times 195,145 \times 114$, col. A. Vandekerchhove, Ingelmunster 43, steht inm aber gut, 1970, latón, $63 \times 26$, pertence al artista 44. mira, vuelo, 1970 , latón, $60 \times 40 \times 44$, pertenece al artista 45. aún z'crde, 1970 , alpaca, $60 \times 45$, pertenece al artista 46. sin título, 1968, latón, $65 \times 68$, col. Félix Roulin 47. sin título, 1970 , latón, $46 \times 75$, pertenece al artista 48 . sin título, 1970, latón, 103 x 59, col. Félix Roulin 49. Pankra I, 1970, óleo/tela, $160 \times$ 160, col. Van den Abbeel 50. Pankra II, 1970, óleo/tela, $160 \times 160$, col. Van den Abbeel 51. Pankra III, 1970, óleo/tela, $160 \times 160$, col. Van Den Abbeel 52. la mujer y la muerte, 1967, óleo/tela, 130 x 97, col. Stephane Janssen, La Hulpe 53. sin tímlo, 1970, óleo/tela $116 \times 89$ col. Stephane Janssen, La Hulpe 54. las visitas II, 1970, óleo/tela $116 \times 89$ col. Stephane Janssen, Ja Hulpe 55. el mar, 1967, óleo/tela $145 \times 95$ col. privada 56. luz parca $I$, óleo/tela $100 \times 100$ col. privada 57. luz parca II, óleo/tela $100 \times 100$ col. privada.

EL Libro Relga. Exposición presentada por la Universidad Nacional Autónoma de México, Biblioteca Nacional, Secretaría de Relacioncs Exteriores, Dirección General de Asuntos Culturales, Enbajada de Bélgica en México, Sala José Mil. Vigil, Uruguay e Isabel la Católica, el 14 de mayo. 
SUbASta dE oRRAS DE ARTe. (85 obras del maestro Amando García Núñez). Exposición presentada en la mansión de las calles de Río Lerma 276, col. Cuauhtémoc, durante los días 14,15 y 16 de mayo.

Nombre de los expositores: José Ma. Velasco, Rugendas, Pelegrín Clavé, Clausell, F. Parra, Byrns, Ramos Martínez, Dr. Atl, Diego Rivera, Siqueiros, Orozco.

Elvira gascón. Exposición de 18 dibujos y 36 estudios preliminares para el libro Elogio de mi cuerpo de Alaide Foppa, presentada por la Galería Arvil, Hamburgo 241 , del 17 de mayo al 5 de junio.

ELSA vázQuez. Exposición de porcelanas presentada por la Embajada de la República Argentina, Hotel María Isabel Sheraton, Galeris, Arte de Coleccionistas, Paseo de la Reforma 352-10A, el 17 de mayo.

Francisco mora. Exposición de óleos, acuarelas, caseínas y dibujos presentada por el Salón de la Plástica Mexicana, INBA, Havre No 7, el 18 de mayo.

impresiones de italia. Tema que tendrá en su sede el pintor Raúl Anguiano, en la calle de Marsella 39, col. Juárez, El Comité en México de la Sociedad Dante Alighieri, el 18 de mayo.

Morsés NIFCo. Exposición de tintas recientes, presentada por el Comité de Actividades Generales, de la Galería C. D. I., Av. Manuel Avila Camacho No 620, el 20 de mayo.

11 pintoras contemporáneas. Exposición de pintura-grabado y dibujo presentada por la Galería José Ma. Velasco, INBA-S. E. P., Peralvillo 55, del 21 de mayo al 13 de junio.

Nombre de las expositoras: Parra Aguirre, Esther Gucrero, Irene Becerril, Puri Yánez, Alicia Venegas, Martha Orozco, Irma Escarzaga, Paulina Trejo, Alicia Saloma, Yolanda Quijano, Elsa Barragán.

carlos alvarado lang. Exposición Obra Gráfica, presentada por el Instituto Nacional de Bellas Artes, Museo de Arte Moderno, Galería de Exposiciones Temporales. P. B. S. I., del 23 de mayo al 27 de junio.

Grabador de asombrosa habilidad, domina igualmente todos los procedimientos gráficos. La palabra domina está empleada aquí con toda intención. En el caso suyo no es la técnica la que determina el estilo de expresión; más bien es la actitud anímica o la visión del grabador la que se refleja en su técnica, aunque por otra parte aprovecha todos los recursos y posibilidades que le brinda. Lo característico cn él es su imaginación genuinamente gráfica, que se deleita en el juego de los blancos y negros. Al contemplar estas estampas se nos comunica algo de la fruición que sintió el maestro al contrastar los valores, al crear, con matices muy delicados, movimientos, profundidad y, digamos, colorido. En las composictones gráficas de este artista artesano hay que penetrar pausadamente, que por cierto no está en consonancia con una época en que el sosiego y la devoción por las cosas del espíritu son cada vez más raros.

Paul Westheim 


\section{(De la obra El grabado en madera, Fondo de Cultura Económica, México)}

Presencia de Alvarado Lang en la Vieja Academia de San Carlos. La Academia de San Carlos rinde homenaje a uno de sus más distinguidos maestros, recientemente fallecido, el grabador don Carlos Alvarado Lang, que fuera director de esta institución, y que además fungió por treinta y tres años consecutivos como maestro de su especialidad. Esta actitud enaltece a la Escuela Nacional de Artes Plásticas, no sólo porque cumple con el deber elemental de corresponder a enseñanzas, orientaciones y lealtades, que atañen de manera directa a su vida institucional, sino porque su actitud insiste en el viejo tema de las calidades del hombre que logran permanencia más allá de la muerte; la vigencia. Del mérito, como deseable camino para el cstudiante, el artista y el maestro; y la limpia conducta de una formación profesional que austera, sin alardes de rigor, ni calculación de la modestia, puede mostrar el fruto equilibrado de la sensibilidad y de la técnica, como necesaria dotación de quienes han escogido la carrera de las artes y desean asumirla con eficacia y con dignidad.

La mayor manera de honrar a un espíritu laborioso, es mostrar los frutos de una labor. La verdad va siempre a quienes siempre la predicaron con el ejemplo. Y la evidencia de esa verdad, en tratándose de un prominente artista de la gráfica, es mostrar el fruto de la tarea continuada que a lo largo de varias décadas logró un acervo singularmente valioso. Todos los actos constitutivos de este homenaje, tienen importancia docente y filosófica. No se sigue la costumbre de las dedicaciones cuando se da el nombre del maestro Alvarado Lang al Taller de Grabado; simplemente se afirma que bajo este techo trabajó por muchos años y rodeado de sus alumnos con la práctica del ejemplo y la verdad de la acción, los condujo, en descubrimientos sucesivos, a las diversas estancias de la ejecución gráfica, en sus más finas, complicadas y alucinantes expresiones. Ese taller fue su templo, porque su tarea tuvo como característica mayor la religiosidad con quien llenó de esmeros y delicadezas el tratamiento de sus láminas y la obtención de estampas en la más variada gama de procedinientos. Por cso lleva su nombre. Ello contrasta con la costumbre de distribuir nombres, dignidades y honores sin justificación alguna. Los alumnos de San Carlos tendrán siempre una respuesta lógica para esa dedicación: es que en este lugar, utilizando el viejo arsenal de esta Acadenia, vigilando los procesos de la acidulación y conduciendo las planchas a la presión de los tórculos, formó las nuevas generaciones de grabadores mexicanos, al lado de quienes continúan enseñando con las viejas tradiciones de Durero, de Rembrandt y de Daumier.

Mientras más se repasa la obra del maestro Alvarado Lang, mientras más se reflexiona sobre los orígenes y motivaciones de sus temas; mientras más se penetra en la variedad de sus procedimicntos y de sus calidades, al lado de las influencias filosóficas y poéticas de su inspiración, nús queda al observar al nivel del artista; de tal modo, la comunicación es más natural y la valoración es más juiciosa Habrá un paralelo entre la religiosidad con que la obra fue concebida y realizada y el recoginniento con que ahora la contempla el visitante. $Y$ entonces será fácil imaginar ese amoroso fruto de la paciencia que no viola los tiempos de maduración con que la obra se desenvuelve y se realiza; ni recurre a la premura por mucho respetar la concepción y revestirla de los más dignos ropajes. Podrá entonces imaginarse cómo en fuerza de esmero, abrió paso a los buriles y a las puntas, en las técnicas más 
delicadas y exigentes; $y$ cómo se ligaron los procedimientos adicionales, para lograr las penumbras $y$ las tintas densas. Porque sin este minucioso afán, la obra gráfica es imposible; el grabador no tiene oportunidad de cotejo en cada nueva etapa, o en cada parcial proceso; no hay frutos immediatos que la alienten, procede mitad por calculación, mitad por experiencia; se supone que en veces, hay algo de adivinación, o de agudeza sensorial que intuye; porque detrás de los betunes o en la huella de las gubias, sólo se supone el efecto pero no se prueba, ni se coteja, sino hasta la hora de la revelación en que la estampa queda conquistada.

\section{Miguel Álvarez Acosta}

Datos biográficos del artista: Carlos Alvarado Lang nació el 14 de enero de 1905 en Piedad de Cabadas, estado de Michoacán. En 1920 ingresó en la Escuela Nacional de San Carlos para estudiar grabado con el maestro Emilio Valadez.

En 1929 se encargó de la clase de grabado al dejarla el maestro Valadez, siendo director de la Escuela el escritor Manuel Toussaint. A partir de 1930 se organizó más ampliamente el taller de grabado, con nuevos derroteros idóneos con las neccsidades de la enseñanza y el medio, quedando distribuidas las clases de grabado en la forma siguiente: metal, profesor Carlos Alvarado Lang; madera, profesor Francisco Díaz de León; y litografía, profesor Emilio Amero. Así: se inició una nueva etapa para la vida de la estampa, con todos sus procedimientos en el recinto de la vieja escuela.

Fue director de la misma escuela en tres periodos: 1942-1944 y, en dos consecutivos, de 1945 a 1949, sin haber dejado de atender su clase de grabado. l'mpuso in tensamente todas las ramas del grabado, habićndose obtenido magníficos resultados.

En su gestión como director, se editaron bajo su cuidado los siguientes álbumes de estampa: Grabados populares mexicanos. Prólogo de José Garcidueñas, Escuela Nacional de Artes Plásticas, Universidad Nacional Autónoma de México, 1944. 39 estampas populares Instituto Nacional de Bellas Artes. Prólogo de Carlos Alvarado Lang. México, 1947. 19 xilografias de la Academia de San Carlos durante el siglo XIX. Instituto Nacional de Bellas Artes. México, 1949.

Al terminar sus funciones como director, no dejó de atender su clase de grabado.

Ilustró dos libros con grabados en madera de pie: Fragmentos de Heráclito. Traducción de José Gaos. Ediciones Alcancía. México, 1939. Canto a Cuauhtémoc, de José López Bermúdez, Edición del Gobierno del Estado de México, 1950.

Para la publicación Anales del Instituto de Investigaciones Estéticas de la Universidad Nacional Autónoma de México, 1938, escribió un estudio sobre "El grabado a la madera negra". Una aportación de Carlos Alvarado Lang. Esta técnica es conocida por los italianos como mezzotinta y grabado en humo por los españoles. Este procedimiento fue descubierto en el siglo xvi.

En la ciudad de México, estados de la república y en el extranjero, participó en numerosas exposiciones colectivas. En 1947 fue miembro fundador de la "Sociedad Mexicana de Grabadores" y participó en todas las exposiciones colectivas de esa organización. Desde 1948, siendo miembro de la "Sociedad para el impulso de las Artes Plásticas", participó en las exposiciones colectivas de 1949 a 1950 de la misma. En 1950 fue nombrado profesor de la clase de grabado en la Escuela de Pintura y Escultura "La Esmeralda", dependiente del Instituto Nacional de Bellas 
Artes, entonces bajo la dirección del maestro Antonio M. Ruiz y, posteriormente, se hizo cargo de la dirección de la misma escuela desde febrero de 1955 hasta el 15 de mayo de 1961, en que se retiró por enfermedad y obtuvo su jubilación.

Catálogo: AGUAFUERTES: 1. niño $11.5 \times 16.1$ col. Sr. Alcjandro Alvarado Lang 2. interior casa $.25 \times 33$ 3. Banco Nacional de México $.11 \times 16.2$ 4. fundición $14.2 \times 25.2 \quad 5$. retrato $26.1 \times .35 \quad 6$. músicos $18.7 \times .207$. Cristo con cruz $.23 \times$ 23.5 8. paisaje $16.2 \times 11.5$ 9. embestida, $1950, .13 \times 16.510$. interior (pareja acostada) $13.4 \times 16.5$ 11. niña con guitarra $.10 \times 20.5 \quad 12$. Cristo $.31 \times 49.513$. balcón con arcos $.15 \times .12$ AGUATINTAS: 14. Miguel Hidalgo y Costilla 7.3 $\mathrm{x} .25$ 15. paisaje $.18 \times 11.5$ 16. arboleda $22.8 \times 29.4$ 17. hombre tocando guitarra $.15 \times 23.7$ 18. hombre trabajando-color $21.5 \times 15.9$ BARNIZ SLAVE: 19. niño acostado, 1952 20. casucha, 1952, $13.2 \times 14.8$ 21. estudio de árbol, La Villa México, 1942 BURIL: 22. esclauos 34.2 x 26.4 23. estampa de Navidad La Familia $5.7 \times .1324$. florero $20.7 \times .1625$. jinetes en el desierto $23.5 \times 30.5$ LINOLEUMS: 26. paisaje, dos personas y burro $.24 \times 16.527$. hombre tocando gaita (tres triángulos) 28. hombre toro, 1953 (decorados para cerámica) 29. mil cumbres, $1956, .16 \times .3430$. paisaje camafco $.13 \times 15.931$. cedros, $1965, .47$ $\mathrm{x} 13.5$ 32. árbol caido, $1955,31.7 \times 43.5$ 33. aguas sin fronteras $64.5 \times 64.534$ niño sentado 35. puente en el bosque, 1957, .41 x 30.5 LITOGRAFIAS: 36 . árbol con cinco fratas $16.4 \times .11$ 37. paisaje $.18 \times 13.7$ 38. paloma wolando al sol, $15.7 \times .21$ MADERA DE PIE: 39. ihustración $.11 \times 6.7$ 40. columnas en interior $10.5 \times 14.5$ 41. sicmbra $4 \times 4.7$ 42. cosecha de trigo, $11.8 \times 8.9$ 43. res mucrta, $1945,11.9 \times 10.2$ 44. sierro con paisaje (ilustración) 7 x 9.845 . caballos, 1929, $10.3 \times 12$ 46. paisaje, 1935, $12.8 \times 17.6$ 47. troncos, 1935. $265 \times 29.4$ 48. Tepoztlán, 1956, $11 \times 17.5$ 49. árbol y sembradio $10.3 \times 11.950$. Ex-Libris J. A. Lang $4.5 \times 3.5$ 51. casa $n^{\circ} 40$ (calle de Rodríguez Puebla), $16.3 \times 14.452$. palmeras y árbol $7.7 \times 2.553$. animales retozando $.8 \times 1154$. animales ordeñando $39.8 \times 23.955$. caballo relinchando $.25 \times 29.8$ MEZOTINTAS: 56 . seis troncos $7.7 \times 9.5$ 57. espacio $12.2 \times 10.7$ 58. dos árboles $11.4 \times .1959$. volcancs, 1943 , $.27 \times .2160$. ilustración árbol y palomas $9.9 \times 6.761$. J. S. Bach, $20.9 \times 25.8$ 62. palomas, $1936,8.6 \times 5.7$ 63. dos árboles $8 \times 5.2 \quad 64$. árbol y paisaje $8.2 \times$ 5.8 65. mubes $9.2 \times 6.966$. campesino muerto, $1954,17.7 \times 11.8$ 67. hombre con máscaras $21.3 \times 16.568$. cielo y montes $.14 \times 20.3$ ORNAMENTOS PARA CERAMTCA: 69. circulo con hojas 70. tres circulos 71. tres circulos 72. tres circulos PUNTAS SECAS: 73 desbordamiento del Lerma 30.6 x 22.874 . empalizada $24 \times .16$ 75. mujer con jarras, $1958,9.4 \times 13.276$. mujeres (ilustración ), 1950, $8.5 \times 8.977$. india y casa, 1950, $8.1 \times 1.178$. fundición $3.3 \times .20$ 79. río frio, 1954, $11.5 \times 15.7$ 80. la jornada, 1957, $13.3 \times 7.5$ 81. mendiga, 1957, $10.8 \times 21.2$ 82. niños (interior), 1956, $9 \times 13.2$ 83. calle de Tula, 1958, $16.5 \times$ .24 84. cruz, araña y moscas $11.9 \times 17.585$. choza $25.2 \times .16$ 86. rancheria, 1957.

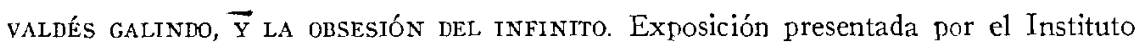
Nacional de Bellas Artes, Galerías del Palacio de Bellas Artes, Sala Verde, el 24 de mayo.

PEDRO PREUX. Exposición de tapices, presentada por el Instituto Nacional de Bellas Artes, Museo de Arte Moderno, Galería de Exposiciones Temporales p. b. s. d., el 23 de mayo.

Datos biográficos del artista: Pedro Preux nació en París en 1932. Llegó a México en 1942 en calidad de refugiado español. Tras algunos años de estudios de medicina, se dedicó a aprender técnicas textiles y más tarde viajó a Aubusson (Francia) para apropiarse y practicar la técnica del tejido del tapiz (basse lisse) bajo la supervisión de Michel Tourliére. Allí mismo trabajó con Jean Lurcat, quien 
le trasmitió los principios pictóricos del tapiz. A su regreso a México fundó y dirigió el Taller de Tapiz de la Escuela de Discño y Artesanías (INBA) y otro taller en la Escuela Nacional de Artes Plásticas (UNAM). En 1965 volvió a París para complementar algunos estudios en la manufacture nationale (Gobelins). Ha colaborado con el Colegio de México y con el Banco de México.

Catálogo: 1. apocalipsis, tapiz, $2 \times 3$ mts. tejido por L. Sastré ejemp. $2 / 4$ 2. l'cspoir, tapiz, $170 \times 1.20 \mathrm{mts}$. tejido por L. Sastré ejemp. 2/6 3. otro mundo, tapiz 1.10 $\mathrm{x} 1.70 \mathrm{mts}$. tejido por M. López, ejemp. $3 / 6$ 4. cl árbol de la vida, tapiz, $1.60 \mathrm{x}$ $1.37 \mathrm{mts}$. tejido por L. Sastré, ejenp. 4/6 5. destrucción y muerte, tapiz, 1.20 $\mathrm{x} 1.55 \mathrm{mts}$. tejido por L. Sastré, ejemp. 3/6 6. y voluió la noche, tapiz, $1.20 \mathrm{x}$ 1.54 mts. tejido por Cosme Velázquez, ejemp. $3 / 6$ 7. Tonatiuh, tapiz, $1.70 \times 2.50$ nits, tejido por E. Gilbon, ejemp. 1/6 8. los astros, tapiz, $1.20 \times 1.70$ mis. Lejido nor E. Gilbon y E. Gutiérrez, ejemp. 1/6 9. punto de fartida, tapiz, $1.05 \times 2$ mts. tejido por L. Sastré, ejemp. $3 / 6$ 10. invierno, tapiz, $1.40 \times 1.80 \mathrm{mts}$. tejido por L. Sastré, ejemp. 1/6 colección Sr. Enrique Centeno 11. L'eau Trouble, tapiz, $1.60 \times 2.12 \mathrm{mts}$. tejido por L. Sastré, ejemp. $2 / 6 \quad 12$. las noches del pasado, tapiz, $1.20 \times 1.70$ mts. tejido por L. Sastré, ejemp. 1/6 13. eclipse, tapiz, $1.20 \times 1.80 \mathrm{mts}$. tejido por L. Sastré, ejemp. 1/o 14. Jnanito Pelloyo, linogratbado, 20.7 × 12 cms. blanco y negro 15 , bonsoir monsicur Balzac, linograbado, 13.1 × 10 cms. 3 placas 16. Cuyutlán, linograbaio $16.7 \times 22.2 \mathrm{~cm} .4$ placas 17. la ola verde, linograbado, $16.7 \times 22.2 \mathrm{~cm} .4$ placas 18 . desde dentro (in memoriam Leo) linograbado $19 \times 29.5 \mathrm{~cm}$. 6 placas 19. los jinetes del Apocalipsis, linograbado, $20 \times 29.7 \mathrm{cms}$. 6 placas 20 . los soles dc octubre, linograbado, $20 \times 28 \mathrm{cms}$. 6 placas 21. el árbol de la vida, linograbado $27.8 \times 16.8 \mathrm{cms}$. 6 placas 22 . el principio y el fin, linograbado, $20.1 \times 25.1 \mathrm{cms}$. 6 placas 23. jude, linograbado, $18 \times 26.1 \mathrm{cms}$. 6 placas 24 . Erctz Israel, linograbado, $20 \mathrm{cms}$, de diánetro (círculo), 6 placas 25. thou shalt not forget, linograbado, $16.5 \times 22.2 \mathrm{cms}$. 6 placas.

KubLI 71. Exposición presentada por la Galeria Edvard Munch, Paseo de la Reforma 489 , el 24 de mayo.

LENI DE servín. Exposición Homenaje de obras, presentada por la Galería Municipal, F. Ramírez Osorio, Plazuela de Los Sapos, 6 Sur 503, Puebla, Pue.

Datos biográficos del artista: Leni de Servín nació en Tallín, Estonia. Radicó y estudió en Philadelphia, U. S. A. Llega a México becada y se queda a vivir. Fatalmente Leni fallece en 1969, en este país por el que sintió un gran anor.

Después de ardua y tenaz labor de preparación profesional, cuando Leni de Servín se realizaba en plenitud, con aterradora impunidad la muerte cortó el hilo de su pródiga existencia.

Nos deja un legado de arte muy personal, dinámico y viviente.

Tal vez debiera hablar de sus composiciones, de su paleta o del recuerdo que tengo de Leni cuando por los teatros del INBA o del IMSS la descubría dedicada en captar el movimiento de sus danzantes con su pincel luminoso; pero nada puedo decir de ella que no lo digan ya sus cuadros, que hablan elocuentemente al espectador con un lenguaje claro, persuasivo y cálido, de una vida, la vida de Leni de Servín.

JENARO SARDANETA V. 
FERnANdo Cabaliero. Exposición presentada por la Casa de la Cultura, y el Gobierno del Estado de México, Dirección de Educación Pública, en Toluca, del 14 de mayo al 4 de junio.

PILAR CASTañedA. Exposición presentada por la Fundación Cultural Miguel Cabreta, Garcia Vigil, 808 (los arquitos), Oaxaca, Oax., el $1^{\circ}$ de mayo.

\section{JUNIO}

PILAR CASTAÑEDA. Exposición presentada en 45 variaciones sobre el tema capricho floral, de pintura (óleo), dibujo (pastel), relieves y objetos (cerámica, esmalte, madera y clavos), por las Galerías Mer-Kup, Molière $328-C$, el $1^{\circ}$ de junio.

XILonen. Exposición de pintura abstracta, presentada por el Museo de las Culturas, INAH/S. E. P., Moneda 13, el 3 de junio.

vi concurso nacional para estudiantes de artes plásticas. Exposición de obras seleccionadas, presentada por la Galería Chapultepec, INBA, Insurgentes Sur número 11 bis, el 7 de junio.

Nombre de los expositores: Jorge Pablo de Aguinaco, Elizabeth Avila M., Ma. Teresa Berlanga, Guillermo Bonley, Edwin F. Brynson, Michele $P$. de Canales, Martha Cánovas, Guillermo Cisneros, Juan Ramón Chán A., John Chichester, Ana Gloria Díaz D., Carlos Diaz Mora, Fernando Díaz de la S., Marguerite Drewre, Juan Gilberto Durán, Ma. Hortensia Esponda Gaxiola, Sergio Gallegos Marin, Luis Manuel Gómez, M. Martha Esthela Garcia V., Ma. Lidia Garcia B., Jackie Hartley, Raúl Izquierdo, Ramiro Jiménez P., Ma. Isabel Jirash R., Ma. Isabel Kastel, Paul V. Kindhard, José López L., Hesiquio López Lucho, Julio Martinez S., Cecilia de Mers, Fred Newman, Jorge Ochoa Romero, Guadalupe Olivares. Olga Ortega Olivares, Joaquin Ortega Esquivel, Gustavo Osuna G., Taurino Pacheco, Lucia del Carmen Pérez, Antonio Pérez Iimón, Doninique Pinel, J. Jesús Ramirez G., Antonio Ramirez Ch., Vicente Rendón, Juan Carlos Reyes G., Guillermo Rivas R., Ma. Esther Romero, Elsa Romo D., Eugenia Sains B., Gustavo Sánchez T., Katarina Singer, Eusebio Torres R., Carlos Villegas Marcial, Ma. Luisa T. Vda. de Zambrano, José Guadalupe Zavala E.

DORA Gómez DE SETIEN. Exposición de pintura, presentada por el Seminario de Cultura Mexicana, Sala de Arte, Brasil $31,2^{\circ}$ piso, del 8 al 25 de junio.

momenaje a emiltano zapata. Exposición de 59 obras de artistas mexicanos, presentada nor el Departamento del Distrito Federal, Dirección General de Acción Cultural y Social, Galerías de la Ciudad de México, Alameda Centra1, del 8 al 30 de junio.

Nombre de los expositores: Ignacio Aguirre, Jesús Alvarez Amaya, Manuel Amaral, Raúl Anguiano, Anónimo, Luis Arenal, Elizabeth Avila, Alberto Beltrán, 
Angel Bracho, Genoveva Cámara, Erasto Cortez Juárez, Luis Chacón, Jesiis Escobedo, Leopoldo Estrada, Arturo Garcia Bustos, Lorenzo Guerrero, Javier Iñiguez, Sara Jiménez, Carlos Jurado, Roberto Malfavón, Leopoldo Méndez, Adolfo Mexiac, Francisco Mora, Antonio Nieto, Isidoro Ocampo, Leticia Ocharán, Froylán Ojeda, José Guadalupe Posada, Mercedes Quevedo, Everardo Ramirez, Ramón Reyes, Salvador Romero, Mariana Yampolsky, Alfredo Zalce.

Catálogo: 1. reparto de tierras 2. pueblo soberano 3. Zapata 4. campesino 5. Zapata 6. tierra y libcrtad 8. la muerte de Zapata 9. Calpuleque Eniliano $\mathrm{Za-}$ pata 10. Zapata 11. la tierra 12. Zapata 13. juzentud campesina 14. Zapata y Cárdenas 15. zapatistas 16. Homenaie a Emiliano Zapata 17. lucha contra Huerta 18. Zapata (cabeza) 19. Zapata a caballo 20. tierra y libertad 21. la tierra debe ser de quien la trabaja 22. campesino 23. Zapata 24. caporal 25. paisaje 26. plan de Ayala 27. Zapata 28. zapatistas 29. sembrador 30. la yunta 31. Zapata 32. Emiliano Zapata 33. la tierra 34. el mural 35. tres generaciones de campesinos 36. Zatata con leyenda 37. la tierra es de quien la trabaja 38. Zapata 39. General Emiliano Zapata 40. el prisionero 41. tengo sed 42. Zapata 43. Zapata y Villa 44. Constitución de 1917 45. Planes de Ayala y San Luis 46. Zapata 47. Zapata 48. la muerte de Emiliano Zapata 49. Zapata 50. homenaje al Héroe 51. Zapata 52. Emiliano Zapata 53. prisionero 54. Zapata 55. progreso campesino 56. Emiliano Zapata 71 57. la muerte en Chinameca 58. la juventud de Zapata 59. la prensa y la Revolución.

myra LANDAU. Exposición presentada por la Galería Pecanins, Hamburgo 103, el 8 de junio.

rosa maría sustaeta. Exposición de dibujos, presentada por el Departamento del Distrito Federal, Dirección General de Acción Cultural y Social, Galerías de la Ciudad de México, Centro Social Popular Aquiles Serdán, Puerto Tampico número 4, esquina con Puerto Guaymas, ampliación de la Colonia Casas Alemán, del 9 al 30 de junio.

ROHER. Exposición de pinturas, presentada por cl Departamento del Distrito Federal, Dirección General de Acción Cultural y Social, Galerías de la Ciudad de México, Centro Social Popular Leandro Valle, Av. Sur 8 y Oriente 241, Col. Agrícola Oriental, del 9 al 30 de junio.

df́az CañEDo. Exposición de pinturas, grabados y dibujos, presentada por el Instituto Francés de América Latina, Nazas 43, el 9 de junio.

GRUPo C/10 CERAMISTAS. Exposición stoneware presentada por el Instituto Nacional de Bellas Artes, Galerías del Palacio de Bellas Artes, Sala Internacional el 9 de junio.

holanda. país y pUiblo. Exposición presentada por el Departamento del Distrito Federal, Dirección General de Acción Cultural y Social, Galerías de la Ciudad de México en el Centro Social Popular "José Maria Pino Suárez", Calzada de la Viga y Guillermo Prieto, Col. Jamaica-Merced, del 10 al 30 de junio.

José luIs Netra. Exposición de fotografías presentada por el Departamento del Distrito Federal, Dirección General de Acción Cultural y Social, Galerías de la Ciu- 
dad de México en el Centro Social Popular "Gral. Ignacio Zaragoza", Av, Oriente 154 y Calle Sur 121, Col. Escuadrón 201, del 10 al 30 de junio.

Datos biográficos del artista: José Luis Neyra, nació en México, D. F., en 1930. Ocupación quiropedista. Interesado en Fotografía en 1961.

LolA cuero. Exposición 50 años de creación artística, presentadat por el Instituto Mexicano Norteamericano de Relaciones Culturales, A. C., Hamburgo 115 (galería Nabor Carrillo), el 10 de junio.

Por esos dias, una nueva pasión artística la alcanzó, que am cuando aparcntemente lejana de lo que hasta entonces había emprendido, llevaba en su seno nucho de sus inquietudes artísticas: nos referinos al teatro guignol que junto con Germán Cueto, Elcna Huerta, Leopoldo Méndez, Ramón Alva de la Canal y el que esto escribe, iba a ser obra perdurable. No es extraño que en este empeño tomaran parte fuera de mí, exclusivamente escritor, cuatro pintores. $Y$ es que cl teatro infantil reclana, además de la obra cscrita y aun por encima de ella, todas las formas de la pintura en fondos, laterales, luces, decoraciones y además en los munecos, que deben ser obras maestras de escultura y decoración al mismo tiempo. Lola Cueto abrazó, como hemos dicho, con pasión esta nueva empresa que ha seguido hasta hoy con renovado impulso cada día.

German List Arzubide

ADOLfo QuiNTERo. Exposición Homenaje (1957-1971) de grabados "El pescador mexicano", presentada por el Instituto Nacional de Bellas Artes, Museo de Arte Moderno, Galería de Exposiciones Temporales, planta alta, del 10 de jumio al 4 de julio.

Esta exposición de Grabado Mexicano es sencillamente, una exposición de grasiones desmedidas plásticamente, ni es una exposición más de las que en boga se presentan, tratando de "apantallar" al público con supuestas búsquedas formales, con "calidades de texturas" y "accidentes controlados", o simplemente con abstracciones y juegos más o menos ingeniosos de formas sui generis, de los que son tan afectos las primadonas del arte para élites selectas.

Esta exposición de Grabado Mexicano es sencillamente, una exposición de grabado, que en formas realistas, expresionistas ( $\sin$ ser un arte comprometido con el extranjero, pero obviamente comprometido con mi pueblo) presenta un estado de ánimo, una vivencia de nuestro pueblo, en su diaria lucha por ser un hombre de su tiempo.

En mi actitud de artista ante el compiejo mundo que vivinos, deseo presentar a la opinión de todo espectador, la conciencia de honestidad protesional que debe tener el artista clentro de la sociedad.

Crear una obra con profundas raices humanas, es decir, crear un arte humanista, partiendo de que el verdadero arte debe ser aquel que tenga "armonía en la forma y utilidad social en el contenido" al servicio de la cultura de nuestro pueblo $\sin$ rebuscamientos esotéricos o actitudes antimexicanas por tratar de ser "artista" supuestamente cotizado a grandes precios en el extranjero, pero desconocido o desarraigado de mi tierra. 
Por estas razones, ahora, en forma sencilla, presento a ustedes un esfuerzo emocionado de sincero homenaje al pueblo mexicano, fuente de inspiración de mi obra, en este caso, "El Pescador Mexicano".

Adolfo Quinteros

Nació en la ciudad de Chihuahua, Chilı, el primero de junio de 1928. Hizo sus estudios primarios en una modesta escuela oficial de su estado: desde temprana edad destacó entre sus compañeros de estudio por su facilidad para el dibujo. Durante su ctapa escolar en los grados quinto y sexto, en concursos de dibujo organizados por la Dirección Federal de Educación en el Estado, obtuvo el primer lugar respectivamente en cada año, sobrc todos los participantes de las escuelas oficiales de la localidad. Al finalizar sus estudios superiores, junta unos cuantos pesos y al conseguir una exigua beca, que le otorga el Gobierno del Estado, por mediación de sus macstros viene por primera vez a la capital muy joven, sin experiencia, la falta de recursos econónicos, le obliga a regresar a su tierra, pero con la idea firme de regresar a continuar sus estudios truncados; por fin nuevamente insiste buscando una nueva oportunidad, misma que consigue con la valiosa ayuda que le proporciona el diputado (en ese tiempo) Prof. J. de Jesús Barrón y nuevamente el estado de Chihuahua le concede otra beca más amplia que la anterior ( $\$ 100.00$ mensuales).

Regresando nucvamente a la capital de la República se inscribe como alumno regular de dibujo y pintura en la Academia de Bellas Artes (Academia de San Carlos), hoy Escuela Nacional de Artes Plásticas de la UNAM.

De 1951 a 1955, estudia y simultáneamente comienza a trabajar como Dibujante en la Campaña Nacional de Alfabetización y Educación Extraescolar de la S. F. P., ganando $\$ 50.00$ pesos mensuales de gratificación.

Durante dos años trabaja y pinta solo y a invitación hecha por la pintora y grabadora Saral Jiménez, entra al taller de Gráiica Popular, el día siete de noviembre de 1957, fecha que será muy importante en su futura formación profesional en el arte.

De recién ingreso participa en todos los trabajos colectivos de esta organización, con una crítica y autocrítica que determina su formación; ocupa varios puestos directivos, pernanece de 1957 a 1967. Recorre el sureste de la República en viaje de estudio, junto con un grupo de catorce artistas del TGP a invitación especial de la familia Lima Zuno, con el fin de plásticamente, incorporar esa región, por su belleza natural, a la economía del país por medio del turismo, visitando los estados de Veracruz, Tabasco, Campeche, Yucatán y el territorio de Quintana Roo, e isla de Mujercs.

En ese nismo año de 1957 obticne la prinera mención honorifica en el Salón Anual de Grabado organizado por el Salón de la Plástica Mexicana e ingresa simultáneanente como niembro activo; en la actualidad es miembro del Consejo Consultivo de esta organización.

En el año de 1959, dos años después de su ingreso al TGP, obtiene el premio Nacional de Grabado en el IV Salón Nacional de Grabado, convocado por el Instituto Nacional de Bellas Artes. 
En la primera Bienal Panamericana en México (en la Exposición Paralela) obtiene mención honorífica.

En 1959 ingresa al Jardín del Arte y llega a dirigir esta organización siendo. presidente en los años de 1966 a 1967, que depende del Instituto Nacional de la Juventud Mexicana; en 1968 es invitado por el Lic. Fernando Córdoba Lobo (entonces Jefe del Depto. Cultural del INJM) a participat como miembro del Jurado del III Concurso Nacional de Pintura, Grabado y Escultura; en ese mismo año de 1968, participa activamente en el I Congreso Nacional de Artes Plásticas organizado por el Departamento Cultural del INJM; en este año de 1968 dicta conferencias en el estado de Guerrero y participa en dos ocasiones en el Curso Vivo de Arte de la UNAM organizado por el maestro Alberto Híjar.

En 1964, la Secretaría de Marina, por medio del Consejo Nacional Consultivo de Pesca, le encarga dos murales para el Primer Salón del Mar y sus recursos, en la IV Feria del Hogar, efectuada en el Auditorio Nacional. En el año de 1960, al conmemorarse el Ciento Cincuenta Aniversario de nuestra Independencia y Revolución Mexicana respectivamente, el TGP organiza un concurso internacional de grabado, para la realización de la portada de su álbum 450 Años de Lucha, "Honenaje al Pueblo Mericano", obtiene el primer lugar y el honor de ver publicado en la portada de ese álbum conmemorativo que recorre el nundo, presentándose en todas las embajadas en que México tiene representación diplomática; esta obra es a color y se titula "Crauhtémoc contra el mito".

En 1960, después de conocer casi toda la República Mexicana, viaja a la Unión Soviética; en este viaje lleva la representación del TGP, como Secretario General del mismo, visita los principales museos de Bélgica, Holanda, Alemania Oriental, y por supuesto de Moscú, Leningrado y Kiev.

Descle 1957 hasta la fecha participa en exposiciones colectivas e irrdividuales, en el TGP de 1957 a 1967.

Jardín del Arte 1959 a 1971.

Catálogo: 1. llegada del camarón, punta seca $.18 \times 19.5$ 2. preparándose para la pesca, $.24 \times .12$ punta seca 3. pescadores en Mezcaltitan $10.5 \times 22.5$ 4. guardias para la pesca $.09 \times 15.5$ 5. Pátacuaro $.27 \times 17.5$, punta seca 6 . en Verachis 19 $\mathrm{x} 13.5$, punta seca 7. pescadores, Veractuz $16.5 \times 17.5$, punta seca 8 . pescando camarón, Mezcatitan 23.5 × 10.5, punta seca 9. paisaje tabasqueño $22 \times 10.5$ punta seca 10. pescando camarón $.18 \times .27$, punta seca 11, explotación irracional de la toritga $.17 \times 29$, barniz suave 12 . tortugas $.18 \times 33.5$, barniz suave 13 . levantondo el chinchorro, Veracruz $19.3 \times 33.3$ barniz suave 14. astilleros de Lerma $.15 \times 25.3$, barniz suave grabados en linóleo. 15. homenaje al pescador mexicano $22 \times 8816$. amanecer en Mezcaltitan, $35.5 \times 25.5$ 17. pescadores de Isla Mujeres $.51 \times .4218$. chinchorro $.50 \times 38.519$. pescando camarón $.50 \times 38.5$. Tecolotita de linóleo $.50 \times 38.5$ 20. buena pesca I, $65.8 \times .32$ 21. fuerte está el sol $.66 \times 32.522$. rumbo al morcado buena pesca $I, 65.9 \times .32$ 21. fucrte está el sol $.66 \times 32.522$. rumbo al mercado $63.5 \times .41$ 23. pescando camarón (Cuitzillo) $59.5 \times 44$ 24. pescando camarón (Caimanero) $.71 \times .4825$ el almendrón $44.5 \times .6626$. rumbo al mercado $I I .69 \times 46.5$ 27. mercadito $82.5 \times 52.5$ 28. buena pesca II, $69.3 \times 41.5$ 29. barcas de Progreso $.65 \times 40.5$ apuntes (del $N^{\circ} 30$ al $N^{\circ} 47$ las medidas son de $.33 \times .25$ ) 30 . barco on construcción 31. sacando caracol (Isla Mujeres) 32. vendedores de pescado (Progreso) 33. árbol almendrón (Isla Mujeres) 34. mercado (Campeche) 35. pescadores (Campeche) 36. destaiando tiburón (Campeche) 37. destazando tiburón (Campeche) 38. destazando tiburón (Campeche) 39. destazando tiburón (Cam- 
peche) 40. en Campeche 41. pescando con arpón (Isla Mujeres) 42. pescando con red (Isla Mujeres) 43. carreta (Campeche) 44. pescando con arpón I 45. pescando con arpón II (Campeche) 46. saliendo a cazar cazón (Campeche) 47. Barcas (Campeche) 48. Juanita y Venancio $42 \times .25$ 49. vendiendo pescado $47.5 \times$ .25 50. mal tiempo $.50 \times 32.5$ 51. pez martillo $.50 \times 32.5$ 52, muelle (Isla Mujeres) $.85 \times .25$ 53. recogiendo camarón (Mezcaltitan) dibujo 54. recogiendo camarón (Mezcaltitan) apunte :32 x.24 55. pescadores concha perla 1 56. pescadores concha perla II 57. Jennet (Canal de los Manglares -Isla Mujeres-) $32.5 \mathrm{x}$ .25 58. bucanero II .25 x.33 59. playa (Progreso) $.25 \times .33$ 60. arreglando velas $.25 \times .33$ 61. desde el mirador (Isla Mujeres) $.25 \times .33$ 62. punta sur (Isla Mujeres) $.25 \times .33$ 63. punta sur II (Isia Mujeres) $.25 \times .33$ 64. pez martillo y casón (Campeche) $.25 \times .33$ 65. Escuinapa $.28 \times 21.5$ 60. llegada del pescador $.24 \times .32$ 67. rumbo al mercado (Tuxpan) $.24 \times .35$ 68. patrulla Federal I $.24 \times .32$ 69. patmlla Federal II, $24 \times .32$ 70, patrulla Federal III .24 x .32 71. llegada del pescador (Mezcaltitan) $.35 \times .24$ 72. cooperativa, $.35 \times .24$ 73. cooperativa (J. M. Morelos) $.35 \times .2477$. pescadores de liza en Cuitzillo $I, .35 \times .2478$. pescadores de liza en $35 \times .24$ 77. pescadores de liza en Cuitzillo $I$, $.35 \times .2478$. pescadores de liza en Cuitzillo II, $.35 \times .24$ 79. pescando en el tapo $.35 \times .2480$. pescando en el tapo (Cuitzilio) $.35 \times .24$ 81. rancho Felipe Ponce $.35 \times .2482$. centro pesquero $.35 \times$ .24 83. Mezcaltitan (Nayarit) I $.35 \times .24$ 84. Mezcaltitan (Nayarit) II $.35 \times .24$ 85. llegada de los pescadores $.35 \times .24$ 86. cargando $.35 \times .2487$. Mezcaltitan $.35 \times$ .24 88. embarcadero $.35 \times .24$ 89. frente a la cooperativa $.35 \times .2490$. tapo Tecolotitla $.35 \times .24$ 91. peso de camarón $.35 \times .24$ 92. zócalo $.35 \times .24$ 93. los manglares $.32 \times .24$ 94. barra (Sancochadero) $.32 \times .24$ 95. llegada de pescadores $.32 \times$ .24 96. barra $.32 \times .24$ 97. Cuitzillo pato $.32 \times .24$ 98. pesca de liza $.32 \times .24$ 99. descargando $.32 \times .24$ 100. vendiendo chirros $.32 \times .24$ 101. un pescador $.32 \times$ .24 102. Puerto Juárez $43 \times 25$ 103. Anochecer (Isla Mujeres) $32.5 \times .25104$. festin $.32 \times .25$ 105. saliendo a pescar .25 x 60.5106 . isla mujercs $.47 \times .25107$. Campeche $32.3 \times .25$ 108. festín $32.3 \times .25109$. los cuervos $32.3 \times .25110$. canal de Tecolotitla $.32 \times 23.5111$. carpintería (Mezcaltitan) $.35 \times .24112$. Morelos $.35 \times .24$ 113. calle Porfirio Díaz $.35 \times .25$ 114. camino a Mundac $.33 \times .25115$. pescadores, Veracruz $.43 \times 21.5116$. astillero de Isla Mujeres $.44 \times 29117$. pescando con arpón .25 ×.33 118. frigorífico (Progreso) $32.5 \times .25$ 119. Campeche, Camp. - pulpo- .32 x.25 120. mesón del Pescador $.50 \times .25$ 121. calafeteando .60 $\times 32.5$ 122. bucanero $I I, 62.5 \times .25123$. llegando $.25 \times .57$ 124. calafeteando (Campeche) $.58 \times 32.5$ 125. viene el brisote (Progreso) $.50 \times .33126$. muelle fiscal $.33 \times .50$ 127. Pancho y los niños $.25 \times 32.5$ 128. llegando $.50 \times 32.5129$. panteón civil (Isla Mujeres) $32.5 \times 49.5$ 130. varadero (J. M. Vela) $.50 \times 32.5$ 131. palmera (Isla Mujeres) $45.5 \times .43$ 132. pescando camarón $67 \times .41133$ al 137. cinco apuntes Tecolotitla $.24 \times .35$.

la ciudad de méxico de josé guadalupe posada. Exposición presentada por el Museo de la Ciudad de México, Dirección General de Acción Cultural y Social, Departamcnto del Distrito Federal, Pino Suárez Núm. 30, el 11 de junio.

PER ANIERson. Exposición de grabados, presentada por el Departamento del Distrito Federal, Dirección General de Acción Cultural y Social, Galerías de la Ciudad de México en el Centro Social Popular "José María Morelos y Pavón" Lago Trasimeno y Lago Ene, Col. Pensil, del 11 al 30 de junio.

EDMUNdo aquino. Exposición de tintas y serigrafías, presentada por la Galería de Arte Mexicano-Florencia, Florencia 35, el 11 de junio.

Datos bingráficos del artista: Edmundo Aquino, nace en Zimatlán de Alvarez, Oax., en 1939. Estudia en la Escuela Nacional de Artes Plásticas de la UNAM, de 1958 a 1962 . 
ALANIz. Exposición de 30 acuarelas oníricas, presentada por el Instituto de Arte de México, Puebla 141, el 11 de junio.

ACtoeromanías. Exposición colectiva presentada por la Galería Edvard Munch, Paseo de la Reforma 489, del 14 al 28 de junio.

Nombre de los expositores: Aníbal, Arévalo, Durán, Vázquez, Góngora, Kubli, Maciel, Pal Kepenyes, Silvia Pardo, Victor, Vivar, Vlady.

CARLOS NAUMER. Exposición de acrílicos y acuarelas, presentada por el Instituto Mexicano Norteamericano de Relaciones Culturales, Hamburgo 115, el 17 de junio.

FIONA ALEXANDER. Exposición de grabados y dibujos, presentada por el Instituto Anglo-Mexicano de Cultura, A. C., Antonio Caso N $\mathrm{N}^{2}$ 127, el 17 de junio.

Datos biográficos de la artista: Fiona Alexander, nació en Inglaterra y estudió 5 años Bellas Artes, al recibir su título vino a México a realizar Investigaciones Estéticas y actualmente se encuentra en el Instituto Potosino de Bellas Artes. Estos dibujos y grabados, con algunas excepciones, fueron hechos en México. Ha expuesto en Londres, Bristol y Portsmouth, realizó por algún tiempo proyectos gráficos en París y Nueva Orleáns.

LA EXPRESIÓN PLÁSTICA INFANTIL EN LA FSCUELA PRIMARIA. Exposición presentada por la Galería José Ma. Velasco, INBA/S. E. P., Peralvillo 55, del 18 de junio al 18 de julio.

4 PINToREs. Exposición presentada por las Galerías San Francisco, Sala de Arte, Insurgentes Sur No. 1427, el 18 de junio.

Nombre de los expositores: Muñoz López, Benjamin Pérez Barrios, Pérez Villasante y Eugenio Sixto.

Emilio ortiz. Exposición de collages y obra gráfica, presentada por la galería Arvil, Hamburgo 241 , del 28 de junio al 17 de julio.

LA FAMILIA DEL Hombre. Exposición Internacional de Fotografías, presentada por el Instituto Nacional de Bellas Artes, Club Fotográfico de México, A. C., Galerías del Palacio de Bellas Artes, Salas 1 y 2, el 29 de junio.

FERnANDo garcía ponce. Exposición presentada por la Galería Juan Martín, Amberes 17 , del 29 de junio al 17 de julio.

eduardo onhen. Exposición de 40 dibujos, presentada por el Museo Pedagógico Nacional, Presidente Mazarik Ne 526, el 30 de junio.

Exposicrón 1970-1971. De Plástica audiovisual, presentada por la Escuela de Diseño y Artesanías, INBA/S. E. P., Sala de Exposiciones de la EDA. Balderas 125, el 30 de junio. 
ERASTO CORTÉs JUÁREz. Exposición presentada por la Universidad de las Américas, A. C. Centro de Fuentes para el aprendizaje, primer piso, en Cholula Puebla, el 15 de junio.

teonoro velazco y josé luis colín. Exposición presentada por la Fundación Cultural Miguel Cabrera, García Vigil 818, los arquitos, Oaxaca, Oax. el 26 de junio.

\section{IULIO}

sofía Bassi. Exposición de obras recientes presentada por las Gáalerías Mer-Kup, Molière $328-\mathrm{C}$, el $1^{\circ}$ de julio.

2il. Exposiclón-venta, mayólica de guanajuato, presentada por el Museo Nacional de Artes e Industrias Populares Fideicomiso para el Fomento de las Artesanías BANFOCO, Av. Juárez $\mathrm{N}^{\circ} 44$, del $1^{\circ}$ al 15 de julio.

grlberó ramírez. Exposición de obras presentada por la Galería Chapultepec. INBA/Insurgentes Sur $N^{9} 11$ bis, el 6 de julio.

Fr.incisco marmata. Exposición de obras presentada por la Galeria Chapultepec. Insurgentes Sur No 11 bis, el 6 de julio.

exiosición colectiva gráfica. Presentada por el Instituto Cultural Mexicano Israeli, A. C., Tíber No 12, del 6 al 18 de julio.

Nombre de los expositores: Carlos Olachea, Felipe Bragar, Esther González de Coniceros.

fxúsición-homenaje a manuel rodríguez lozano. (1897-1971). Presentada por el Instituto Nacional de Bellas Artes, Galerías del Palacio de Bellas Artes, Salas 1 y 2, 4 y 5, del 7 de julio al 31 de agosto.

Datos biográficos del artista: Manuel Rodríguez Lozano, nació el 4 de diciembre, en la ciudad de México en 1897. Estudia en la Academia de San Carlos. Viaja a París donde trabaja con el grupo de pintores cubistas Picasso, Braque, Gris y otros. En 1921 regresa a México. Con Antonio Rivas Mercado funda el grupo de intelectuales contemporáneos en 1930. Realiza para la colección Yturbe una serie de retablos con el tema de la muerte en 1933. Asume la Dirección de la Escuela Nacional de Artes Plásticas de la Universidad Nacional Autónoma de México en 1939-40. Funda la revista Artes Plásticas y se hace cargo de la Editorial de la UNAM. La Universidad Nacional Autónoma de Mćxico edita una monografía de su obra con textos de Tosé Bergamín. En 1942 ejecuta $u 11$ mural al fresco en el edificio Jardín, de la calle de Isabel la Católica $\mathrm{N}^{9} 30$, en México, D. F, con el título de "Holocausto". En 1967 El Instituto Nacional de Bellas Artes ordena el desprendimiento del mural "La Piedad en el desierto", y es trasladado al Palacio de Bellas Artes, labor que es encomendada al Centro Nacional de Restauración y Conservación de la Obra Artística. El 27 de marzo de 1971, muere en la ciudad de México. 
Esta exposición organizada por el Instituto Nacional de Bellas Artes en homenaje al maestro Manuel Rodríguez Lozano, es, consccuentemente una invitación a la crítica y a la sociedad para revalorar la significación y trascendencia de su obra en el movimiento pictórico de nuestro país.

Rodríguez Lozano es una personalidad singular, sigue caminos propios en el hacer cotidiano de la imagen del arte mexicano. Rebelde e inconforme con todo lo que le rodea, escoge el camino de la soledad, como si emprendiera la batalla del tiempo, aun a costa de apurar hasta el postrer momento la desesperación y la locura.

Dibujante exquisito, es un esteta de la línea que maneja sin concesiones por los mundos recónditos de la forma. Más preocupado por el ritmo interior en ella contcnido, lo desata en un anhelo de expresar la poesía recogida en los hilos sutiles de la inspiración. Para él, no existen los límites del dibujo, y aun en su pintura, el colort no es sino un medio para señalar el tiempo y el espacio con un mínimo de recursos cromáticos.

No escapa, sin embargo, a la influencia del arte popular como muchos otros; pero al hacerlo parece abrevar en aguas virgenes. Su arte es dramático y espectante como si transitara del brazo del dolor: príncipe de la tristeza. Rodriguez Lozano nos dejó en la dimensión de su obra la polifonía de sus sentimientos, a veces, voz de místicos acentos, aunque paganos son también, el canto que se escucha en cada eco recogido en el espacio rectangular y geométrico de su pintura.

Alfredo Guati Rojo

\section{Pensamiento y Pintura}

Cuando, licuada la nube de la pasión contemporánea, se hagan la historia y el balance de la gran pintura mexicana de este siglo, la figura y la obra de Manuel Rodríguez Lozano aparecerán visibles en toda su pureza. Pero esta pureza no es la esteticista y ciega del arte por el arte. "Es puro e impuro como Shakespeare y como el mar", ha dicho de él José Berganín. Por lo demás, ningún pintor, ningún artista verdaderamente grande ha sido esteticista nunca. El esteticista no es sino una excreencia degenerativa, un adjetivo sin nombre, un acto de no fe, de no creación. Nada tiene que ver Rodríguez Lozano con el arte por el arte, pero mucho con la teoría menos explorada, menos explotada, del arte para el arte. Quizá sea preferible una palabra menos sujeta a interpretaciones impuras que la palabra pureza: Manuel Rodríguez Lozano o la lealtad.

No hay, en efecto, una sola cosa extrapictórica en su creación, y esto es lo que yo llamo su pureza, su lealtad. También Baudelaire - sin un solo truco, sin neologrismos, sin adulterar nada, sin desorbitar las formas tradicionales, sin trastocar el orden del espíritu- llevó la poesía a una nueva dimensión. Es esta lealtad a los límites y a los medios de la pintura lo que me lace hablar de pureza. Pero hay, también, la otra pureza, la otra lealtad en él: la del motivo, la del espíritu, la del pensamiento. $\mathrm{Y}$ ésta tienc dos orígenes: la lucidez del hombre, que es la misma inflexible y perfecta que persiguen los grandes locos, a menudo sin alcanzarla, $y$ su simultaneidad vital con el pueblo, que le permite, como al pueblo mismo, librarse de la máscara, de la mácula de lo popular en el sentido comercial que ha envenenado a tantos artistas a imagen y semejanza de tantos políticos mexicanos. 
Dicho y sabido que ninguna obra de arte puede alcanzar perduración ni ser arte si arranca de una tesis; pero que toda obra de arte hecha en lealtad y en pureza alcanza perduración y tiene, además, una tesis viviente. Así como lo local lealmente encerrado en sus límites y saturado de sus propias esencias penetra en la escala de lo universal por derecho propio, así la pintura de Manuel Rodríguez Lozano, por sus límites y sus esencias, penetra en la conciencia humana como una aplastante protesta social. Es una pintura que está contra todo lo que destruye al hombre: guerra, revolución, máquina, dinero, ciencia aplicada mal aplicada, política, intelectualidad reseca. Es una pintura por el hombre pero también por el pintor, una pintura que nos dice que el obrero debe ir al mitin y el soldado a la trinchera; pero que el pintor debe pintar porque la pintura en su trinchera y su mitin, su calvario y su cruz, su nacimiento, su muerte y su resurrección. La fórmula es tan sencilla que resulta inaceptable para muchos: para los que quieren pintar en el mitin $y$ cn la trinchera y hacer demagogia en el taller.

En un mundo pictórico en que el uso es abuso en materia de color, en el que los creadores parecen querer competir con los progresos científicos del colorido cinematográfico, en un orgiástico trópico de colores que es lesivo a los ojos y que opera como un disfraz deslumbrador de las esencias, la gama fría, desnuda, podría decirse, en que el azul, el blanco, el gris y el verde, para no hablar del asombro falso negro, sirve para revelar la frialdad, la soledad, la desesperación internas del mexicano rodeado de "garzas en desliz" y "relámpagos verdes cle loros", la tragedia del nexicano que agoniza pálidamente entre un derroche de colores, del mexicano, que no se parece a su paisaje.

En un mundo pictórico cuyos monstruos creadores acaparaban empleos y muros sin formar escuela, sin lanzar al mundo discípulos valiosos, Manuel Rodríguez Lozano hace en 1923-1924 el experimento de la gráfica de la niñez mexicana, con indudables alcances freudianos en un momento en el que Freud era casi desconocido en nuestro continente, y lo lleva por varias partes del mundo, con el aplauso de André Lhote y de Ángel Zárraga, entre muchos; orienta a pintores como Abraham Angel, Tebo, Nefero y el cubano Mariano Rodríguez; a escultores como Alfredo Lozano, de Cuba, Francisco Zúñiga, de Costa Rica, Fernando Carbajal, de México; y a fotógrafos tan extraordinarios --si puede decirse en plural-- como Antonio Revnoso.

No quisiera yo que en esta apología suya pudiera verse una actitud peyorativa hacia los demás pintores mexicanos, entre los cuales algunos hay que son muy grandes, independientemente de la grandeza de la escuela mexicana de pintura en conjunto, que Rodríguez Lozano mismo ha sido elocuente en proclamar. El sabe que la medida de su mérito está justamente en la elevada existencia de su obra, no por sobre un mundo de pigmeos, sino a nivel con una floración que tiene muclio de lo monstruoso de los grandes siglos. Y sabe, además, que puede estar tranquilo, porque en ese mundo en el que todos pintan - como en el Renacimiento todos pintaban o escribían- nadie pinta como él, nadie pinta lo que él. El desinterés, la abstracción de sí mismo que se traduce sólo en su mayor fuerza personal, la ciudadanía universal en suma, que caracterizan a Manuel Rodríguez Lozano, caben en una frase que él podría decir: pintar y dejar pintar. Pero pintar. Pero dejar. Parece sólo natural que, expuestas estas condiciones que rodean su obra y su espíritu, se encuentre uno obligado a llegar a la definición única que puede diferenciar a Rodrísuez Lozano de los otros grandes pintores mexicanos. Está fuera de duda que nos encon- 
trannos frente a un artista clásico, frente a un espíritu clásico. Quizás el único del siglo en México.

Ahora ha logrado su aspiración: volver al pueblo que amó y que es otro mar, y desaparecer en él gozosamente.

\section{RODOLFO USIGLI}

Catálogo: Col. Nieves-Bermúdez (del 1 al 110) 1. máquina, 1924, tinta, $19 \times 20 \mathrm{cms}$. 2. naturalcza muerta con balanza, tinta, $17 \times 20 \mathrm{cms}$. 3. naturaleza muerta con máscara, tinta, $17 \times 20 \mathrm{cms}$. 4. soldado francés, tinta, $25 \times 25 \mathrm{cms}$. 5. composición, tinta, $32 \times 26 \mathrm{cms}$. 6. autorretrato, tinta, $13 \times 19 \mathrm{cms}$. 7 . Proyecto para el retrato de Tebo, 1928, lápiz, $34 \times 49 \mathrm{cms}$. 8. proyecto para el cuadro Adolescencia, 1929, lípiz, $34 \times 49$ cms. 9. proyecto para cuadro (desnudo 1), 1929, lápiz, $39 \times 48 \mathrm{~cm}$. in. mujeres, 1929, lápiz, $34 \times 47 \mathrm{cms}$. 11. retrato de mujer con trenzas, 1929 tinta, $23 \times 17 \mathrm{cms}$. 12. retrato de hombre, 1929 , lápiz, $20 \times 20 \mathrm{cms}$. 13, botellas, 1929 , tinta, $25 \times 28$ cms. 14. retrato, 1930 , tinta, $21 \times 31$ cms. 15 . desmudo masculino, 1930, tinta, $25 \times 27$ cnis. 16. boceto para cuadro desnudo femenino, 1930 (series monumentales), lápiz, $24 \times 33$ cms. 17. mujeres en la vecindad, 1930, lápiz, 34 × 44 cnis. 18 . cubiertos, 1930 , tint: $22 \times 28$ cms. 19. estudio para retrato, 1930, lápiz, $22 \times 28 \mathrm{cms}$. 20. retrato $d c$ Isabel, 1930 , lápiz, $22 \times 28 \mathrm{cms}$. 21 . mujer sentada, 1930, lápiz, $21 \times 31 \mathrm{cms}$. 22. grupo de mujeres, 1931, tinta, 31 x $37 \mathrm{cms}$. 23. dos mujeres, 1931 , tinta $31 \times 37$ cms. 24. boceto para el cuadro compartiendo el dolor, 1932, lápiz $35 \times 49$ cins. 25. desnudo femenino recostado, 1933, tinta, $24 \times 32 \mathrm{cms}$. 26. desnudo masculino, 1933, lápiz, $24 \times 32 \mathrm{cms}$. 27. torso masculino, 1933, lápiz, $24 \times 32$ cins. 28. torso desmudo nasculino, 1933, lápiz, $24 \times 32$ cms. 29 . desnudo masculino, 1933, lápiz, $23 \times 32 \mathrm{cms}$. 30. dorso masculino, 1933, tinta, $24 \times 32 \mathrm{cnss}$. 31. desnudo masculino, 1933, tinta, $24 \times 32$ cms. 32. retrato, 1934 , lápiz, $25 \times 32$ cnss. 33. estudio masculino sentado, 1934, tinta, $66 \times 50 \mathrm{cms}$. 34. estudio femenino sentado, 1935, tinta, $66 \times 50$ cms. 35. desnudo femenino, 1935, tinta, $24 \times 33 \mathrm{cms}$. 36. retrato de Antonieta Rivas Mercado, 1934, tinta, $25 \times 32 \mathrm{cms}$. 37 . desnudo femonino, 1935, tinta, $23 \times 33$ cms. 38. estudio masculino, 1935, lápiz, $50 \times 65 \mathrm{~cm} s$. 39. estudio masculino, 1935 , tinta, $48 \times 65 \mathrm{cms}$. 40. paisaje de Acapulco, 1935, tinta, $32 \times 23 \mathrm{cms}$. 41. retrato de Diana Subervielle, 1936 , tinta, $50 \times 66 \mathrm{cms}$. 42 . desnudo femenino, 1936, tinta, $22 \times 28$ cnis. 43. figuras, 1936 , tinta, $34 \times 34$ cms. 44 . las parcas, 1936 (serie monumental), lápiz, $54 \times 72 \mathrm{cms}$. 45. estudio femenino recostado, 1937, tinta, $66 \times 50 \mathrm{cms}$. 46. estudio femenino, 1937 , tinta, $66 \times 50 \mathrm{cms}$. 47 . estudio femenino, 1937, tinta, $50 \times 60 \mathrm{cms}$. 48. estudio femenino, 1937, tinta, $50 \times 60$ cms. 49. estudio fomenino de fie, 1937, tinta, $50 \times 56$ cms. 50 . estudio fomenino recostado, 1937, tinta, $50 \times 60$ cms. 51. pareja, 1937 , tinta, $50 \times 60 \mathrm{cms}$. 52 . estudio femenino sentado, 1937, lápiz, $50 \times 66 \mathrm{cms}$. 53. estudio femenino de pie, 1937, lápiz, $50 \times 66 \mathrm{cms}$. 54. estudio femenino, 1937, tinta, $50 \times 66 \mathrm{cms}$. 55 . boceto para la.s parcas, 1937, tinta, $66 \times 50$ cms. 56. figura con túnica, 1937, tinta, $24 \times 33 \mathrm{cms}$. 57. estudio para el cuadro el pensador, 1937 . lápiz, $66 \times 50 \mathrm{cms}$. 58. dos figuras, 1937, tinta, $50 \times 66 \mathrm{cms}$. 59. dos figuras, 1937 , tinta, $50 \times 66 \mathrm{cms}$. 60 . en la playa, 1937, tinta, $66 \times 50 \mathrm{cms}$. 61. hombre scntado, 1937, tinta, $34 \times 49 \mathrm{cms}$. 62 . niño, 1937, tinta, $34 \times 39$ cmss. 63. estudio femenino sentado, 1938 , tinta, $66 \times 50 \mathrm{cms}$ 64. estudio femenino, 1938 , tinta, $50 \times 66 \mathrm{cms}$. 65. estudio femenino acostado, 1938 , tinta, $50 \times 66 \mathrm{cms}$. 66 . estudio femenino, 1938, tinta, $50 \times 66 \mathrm{cms}$. 67 . estudio femenino, 1938, tinta, $33 \times 50$ cms. 68 . estudio femenino, 1938 , tinta, $50 \times 66 \mathrm{cms}$. 69. estudio masculino, 1938, lápiz, $50 \times 65 \mathrm{cms}$. 70. estudio de mujeres con rebozo, 1939, tinta, $65 \times 50 \mathrm{cms}$. 71 . estudio de nuijeres con rebozo, 1939 , tinta, $65 \times 50$ $\mathrm{cms}$. 72. estudio femenino, 1939, lápiz, $65 \times 50 \mathrm{cms}$. 73. estudio femenino sentado, 1939, tinta, $50 \times 66 \mathrm{cms}$. 74. tres figuras, 1939 , tinta, $66 \times 50 \mathrm{cms}$. 75 . estudio femenino, 1939, tinta, $50 \times 65 \mathrm{cms}$. 76. serie de el mar, 1939, tinta, $48 \times 70 \mathrm{cms}$. 77 . niña sentada, 1940, tinta, 65 × $50 \mathrm{cms}$. 78. boceto para Santa Ana mucrta, 1941, lápiz, 
$65 \times 50$ cms. 79. boceto para la madre tierra, 1941, lápiz, $66 \times 50 \mathrm{cms}$. 80 . boceto para el cuadro la tragedia del desierto, 1941, lápiz, $66 \times 50 \mathrm{cms}$. 81. mujeres con rebozo, 1941, tinta, $65 \times 50 \mathrm{cms}$. 82. estudio de mujercs con rebozo, 1941, lápiz, $66 \times 50 \mathrm{cms}$. 83. estudio de mier con rebozo, 1941, lápiz, $66 \times 41 \mathrm{cms}$. 84. estudio de mujer con rebozo, 1941, lápiz, $34 \times 49$ cms. 85. cstudio masculino, 1941, lápiz, $66 \times 50$ cms. 86. figura recostada, 1941, lápiz, $49 \times 35$ cms. 87 . esiudio desuudo de hombre, 1941, lápiz, $49 \times 35$ cms. 88. estudio desnudo de hombre sentado, 1941, lápiz, $49 \times 34 \mathrm{cms}$. 89. la piedad, 1941 (proyecto), tinta, $34 \times 49 \mathrm{cms}$. 90. amantes, 1942, carbón, 34 x 49 cms. 91. los amantes, 1943 , lápiz, $13 \times 13 \mathrm{cms}$. 92. borto para el cuadro el retorno de la muerte, 1944, lápiz, $49 \times 34 \mathrm{cms}$. 93. amantes, 1945, lápiz, $19 \times 23 \mathrm{cms}$. 94. los amantcs, 1950 , tinta y acuarela $22 \times 24$ cme. 95. mujer desesperada, 1955 , tinta, $15 \times 23$ cms. 96. cstudio fernenino, tinta, $33 \times 50^{3}$ cms. 97. ciriales, lápiz, $35 \times 24 \mathrm{cms}$. 98. las parcas (serie monumental), lápiz, $50 \times 66 \mathrm{cms}$. 99. las parcas (serie monumental), lápiz, $50 \times 65 \mathrm{cms}$. 100 . los amantes (boceto), lápiz, $49 \times 34 \mathrm{cms}$. 101 , el parto (provecto), lápiz, $36 \times 24 \mathrm{cms} .102$. la partila (proyecto), lápiz, $49 \times 34$ cms. 103. holocausto, lápiz, $49 \times 34 \mathrm{cmls}$. 104. retrato de niña, lápiz, $34 \times 49 \mathrm{cms}$. 105. desmido de mujer, tinta, $33 \times 50 \mathrm{cnis}$. 106. proyecto para la madre tierra, tinta, $12 \times 18$ cins. 107 . proyecto de composición, tinta, $18 \times 12$ cms. 108 . estudio de caballo, lápiz $32 \times 23 \mathrm{cms}$. 109 . frasmentos de holocansto, lápiz, $28 \times 21 \mathrm{cms}$. 110. proyecto fara la muerte de la faloma, 1942, tinta, $18 \times 12$ cms. 111. la espera, 1941. Játiz, $60 \times 43 \mathrm{cms}$. col. Rodolfo Usigli 112. estudio, 1957, tinta, 30 x $33 \mathrm{cms}$. col. Ing. Marte R. Gómez 113. cstudio, 1957, tinta, 30 x $33 \mathrm{cms}$. col. 1ng. Marte R. Gómez 114. retrato de José Muñ 1933, lápiz, $47 \times 36 \mathrm{cms}$. col. INBA.PINTURAS 115. retrato de Alfonso Reycs (París, 1915-20), óleo s/cartón, 55 x 46 cins. col. Alfonso Reyes Mota 116. retrato de Andrés Henestrosa, 1924, óleo s/cartón 1.22 × $91 \mathrm{cms}$. col. Andrés Henestrosa 117. retrato de Abraham Angel, 1924, óleo s/cartrin. $59 \times 41 \mathrm{cms}$. col. INBA 118. retrato del Dr. Jaime Torres Bodet, 1925 , óleo s/cartin 63 x 55 cns. col. Dr. Jaime Torres Bodet 119. retrato de Daniel Cosío Villegas, 1936, óleo s/tela, 60 x 50 cms. col. Arq. Manuel Parra 120. desmudo de mujer sentada, 1926, óleo s/cartón, 44 x 38 cms. col. INBA 121. la ramera, 1927, óleo s/cartón, 70 x $60 \mathrm{cms}$. col. Nieves-Bermúdez 122. el joven del sweter, 1927, óleo s/cartón, 114 x $81 \mathrm{cms}$. col, Nieves-Bermúdez 123. Zenaida, 1929, óleo s/tela, 54 x $200 \mathrm{cms}$. col. Lic. José Muro Méndez 124. paloma, 1929 óleo s/tela, 40 × 90 cins. col. Lic. José Muro Méndez 125. muchachas de perfil, 1929, óleo s/tela $87 \times 51$ cnis. col. INBA 126. muchacha. scntada, 1929, úleo s/tela $160 \times 100$ cms. col. INBA 127. mijer desnuda, 1930, óleo $\mathrm{s} /$ tela $170 \mathrm{x} / 5 \mathrm{cms}$. col. INBA 128 . mier con camisa rosa 1931 , óleo s/tela $70 \mathrm{x}$ 49 cms. col. INBA 129. cabeza de mier, 1931, óleo s/cartón, $35 \times 31 \mathrm{cms}$. col. INBA 130. dos mujeres, 1931 , óleo $\mathrm{s} /$ tela, $95 \times 65 \mathrm{cms}$. col. INBA 131. Santa Ana murrta, 1932, óleo s/tela, $37 \times 48 \mathrm{~cm} s$ col. Nieves-Bermúdez 132. Santa Ara nuerta, 1932, óleo s/tela, 37 × 48 cms. col. Nieves-Bermíclez 133. Santa Ana mucrta, 1932, óleo s/tela, 37 x 48 cms. col. INBA 134. Santa Ana muerta con figura, 1932, óleo s/tela, $37 \times 48 \mathrm{cms}$. col. INBA 135. Santa Ana muerta con tres figneras, 1932, óleo s/tela $37 \times 4.8 \mathrm{cms}$. col. 1NBA 136. Santa Ana muerta con dos firnras, 1932 , óleo s/tela 37 x $48 \mathrm{cms}$. col. INBA 137. Santa Ana muerta con cinco figuras, 1932 óleo s/tela. $37 \times 48 \mathrm{cms}$. col. INBA 138. Santa Ana muerta con dos figuras, 1932, óleo s/tela, 37 x 48 cms. col. INBA 139. Santa Ana muerta con tros figuras, 1932, óleo s/tela $37 \times 48 \mathrm{cms}$. Col. INBA 140. Santa Ana mucrta con figira cn rojo, 1932, óleo s/tela $37 \times 48 \mathrm{cms}$. col. 1NBA 141. cabera de Santo Ara mucrta en b!anco, 1932, óleo s/tela, $37 \times 48$ cns. col. INBA 142. Santa Ana min:;ta con dos, figuras en rojo, 1933, óleo s/tcla. $37 \times 48 \mathrm{cms}$. col. INBA 143. Sunir Ana con dos mieres y un niño, 1933 , óleo s/tela, 37 x 48 cms. col. INBA 1 it. retrato de Consuelo, 1933, óleo s/tela $42 \times 30 \mathrm{cms}$, col. INBA 145 . desnudo de hombre, 1933 , óleo s/tela, $48 \times 37 \mathrm{cms}$. col. INBA 146. desnudo para el friso de $S$ onta Ana, 1933, óleo s/tela, $37 \times 11 \mathrm{cms}$. col. INBA 147. torso para el friso de Santa Ana, 1933, óleo s/tela 37 x $14 \mathrm{cms}$. col. INBA 148. desnudo para el friso de Santa Ana, 1933, óleo s/tela, $37 \times 11 \mathrm{cms}$. col. INBA 149. desnudo con abanico para $\mathrm{cl}$ friso de Santa Ana, 1933, óleo s/tela, $37 \times 15$ cms. col. INBA 150. Santa Ana 
mucrta desmuda, 1933, óleo s/tela $37 \times 48 \mathrm{cms}$. col. INBA 151. retrato de Diana Subervielle, 1933, óleo s/tela, $36 \times 49 \mathrm{cms}$. col. Felipe Subervielle 152. la regla, 1935, óleo s/tela, $200 \times 115 \mathrm{cms}$. col. Nieves-Bermúdez 153. el Verdacco, 1935 óleo s/tela, $130 \times 140 \mathrm{cms}$. col. Nieves-Bermúdez 154. desnudo en el mar, 1935 óleo s/ tela, $115 \times 200 \mathrm{cms}$. col. Nieves-Bermúdez 155. paisaje, 1935, óleo s/cartón, $23 \mathrm{x}$ 29 cms. col. INBA 156. paisaje con chimenea. 1935, óleo s/cartón, $24 \times 34 \mathrm{cms}$. col. INBA 157. figura sentada, 1035, óleo s/tela $70 \times 48 \mathrm{cms}$. col. INBA 158. el coloso, 1936, óleo s/tela, $200 \times 110 \mathrm{cms}$. col. INBA 159. el pensador, 1936, óleo s/tela $200 \mathrm{x}$ $115 \mathrm{cms}$. col. Nieves-Bermúdez 160. las tres parcas, 1936, óleo s/tela $200 \times 130$ cmis. col. Nieves-Bermúdez 160. las tres parcas, 1936, óleo s/tela, $200 \times 130 \mathrm{cms}$. col. Nieves-Bermúdez 161. la diosa del amor, 1936, óleo s/tela $200 \times 110 \mathrm{cms}$. col. Nieves-Bermúdez 162. el mexicano, 1936, óleo s/tela, $48 \times 32 \mathrm{cms}$. col. NievesBermúdez 163. el mexicano, 1936, óleo s/tela $40 \times 50 \mathrm{cms}$. col. Nieves-Bermúdez 164. los amnantes, 1937, óleo s/tela $110 \times 200 \mathrm{cms}$. col. Nieves-Bermúdez 165. compartiendo el dolor, 1938, óleo s/tela $83 \times 70 \mathrm{cms}$. col. Nieves-Bermúdez 166. pescador de estrellas, 1939, óleo s/tela $85 \times 70 \mathrm{cms}$. col. Lic. Antonio Luna Arroyo 167. desnudo en la playa, 1939, óleo s/tela $110 \times 200 \mathrm{cms}$. col. Nieves-Bermúdez 168. tres caballos, 1940, óleo s/tela 73 x $92 \mathrm{~cm}$ s. col. María Luisa González Aparicio 169. autorretrato, 1940 , óleo s/tela, $100 \times 60 \mathrm{cms}$. col. Nieves-Bermúdez 170. la tragedia del desicrto, 1940, óleo s/tela, $200 \times 125 \mathrm{cms}$. col. Nieves-Bermúdez 171. las sombras, 1941, óleo s/tela $95 \times 70 \mathrm{cms}$. col. Lic. Federico Bracamontes 172. el alcatraz, 1941, óleo s/tela $70 \times 95 \mathrm{cms}$. col. Nieves-Bermúdez 173. los ciriales, 1941, óleo s/tela $95 \times 70$ cms. col. Nieves-Bermúdez 174. estudio para el mural de la Penitenciaría, 1942, fresco en bastidor de madera (detalle), 50 x60 cms. col. INBA 175. mural pintado al fresco en la cárcel preventiva de la ciudad de México (Lecumberri). Rescatado por el Centro Nacional de Conservación de Obras Artísticas del INBA en el año de $1967,2.60 \times 2.30 \mathrm{mts}$. col INBA 176. la muerte de la paloma, 1942, óleo s/tela, $70 \times 95 \mathrm{cms}$. col. Nieves-Bermúdez 177. retrato de hombre, 1942, óleo s/fibracel, $40 \times 45 \mathrm{cms}$. col. Lic. Ángel Martín Pérez 178. desenvolvimiento, 1942, óleo s/tela $95 \times 70 \mathrm{cms}$. col. Nieves-Bermúdez 179. retrato de Nefero, 1942, óleo s/tela, $120 \times 75 \mathrm{cms}$. col. Nieves-Bermúdez 180 . el rebozo blanco, 1943, óleo s/tela, $95 \times 75 \mathrm{cms}$. col. Jorge Mester y Sra. 181. la selva tropical, 1943, óleo s/tela, $70 \times 95 \mathrm{cms}$. col. Nieves-Bermúdez 182. retrato del Lic. Antonio Luna Arroyo, 1943, óleo s/tela, $48 \times 37 \mathrm{cms}$. col. Lic. Antonio Luna Arroyo 183. el cainismo, 1944, óleo s/tela, $124 \times 89 \mathrm{cms}$. col. Nieves-Bermúdez 184. el sueño, 1945, óleo s/tela, $58 \times 79 \mathrm{cms}$. col. Nieves-Bermúdez 185. reproducción foto mural de Holocausto, pintado al fresco en el Edificio Jardín, I. La Católica No 30 en la Ciudad de México, 1946, $13 \times 6 \mathrm{cms}$. 186. los caballos, 1946 , óleo s/tela, $70 \times$ 95 cms. col. Lic. Federico Bracamontes 187. el camafeo, 1947, óleo s/masonite, $49 \times 37 \mathrm{cms}$. col. Rodolfo Usigli 188. Desprendimiento, 1949 , óleo s/tela, $70 \times 58$ cms. col. INBA 189. el mexicano "torso", 1951, óleo s/tela, $55 \times 65$ cms. col. Nieves-Bermúdez 190. el mexicano, 1951, óleo s/tela, $55 \times 50$ cms. col. NievesBermúdez 191. el mexicano, 1951, óleo s/tela, 49 × $37 \mathrm{cms}$. col. Nieves-Bermúdez 192. el retorno de la muerte, 1951, óleo s/tela, 70 x $95 \mathrm{cms}$. col. Nieves-Bermúdez 193. composición, 1951, óleo s/tela, $95 \times 70 \mathrm{cms}$. col. Nieves-Bermúdez 194. el mericano, 1952, óleo s/tela, $50 \times 40 \mathrm{cms}$. col. Nieves-Bermúdez 195 . retrato de Rodolfo Usigli, 1953, óleo s/tela, $49 \times 37$ cns. col. Rodolfo Usigli 196. el abismo, 1953, óleo s/tela, $95 \times 70 \mathrm{cms}$. col. Nieves-Bermúdez 197. mi atardecer, 1955, óleo s/tela, $70 \times 95 \mathrm{cms}$. col. Nieves-Bermúdez 198. un mundo interior, 1956, óleo s/tela, $48 \mathrm{x}$ $37 \mathrm{cms}$. col. INBA 199. la disputa, 1956, óleo s/tela, $80 \times 65 \mathrm{cms}$. col. Nieves-Bermúdez 200. los amantes, 1958 , óleo s/tela, $95 \times 70 \mathrm{cms}$. col. INBA 201. el mexicano, 1958, óleo s/tela, 49 × $37 \mathrm{cms}$. col. Nieves-Bermúdez 202. dos parejas, 1959, óleo s/tela, $120 \times 75 \mathrm{cms}$. col. Nieves-Bermítez 203. retrato de Alfonso Reycs, 1960 , óleo s/tela, $80 \times 70 \mathrm{cms}$. col. Alfonso Reyes Mota 204. holocausto, óleo s/ tela, $124 \times 177 \mathrm{cms}$. col. INBA 205. la partida, óleo s/tela, $70 \times 95 \mathrm{cms}$. col. INBA 206. el arco en la tierra, óleo s/tela, $70 \times 95 \mathrm{cms}$. col. INBA 207. el rapto, óleo s/ tela, $70 \times 95 \mathrm{cms}$. col. INBA 208. la revolución, óleo s/tela, $70 \times 95 \mathrm{cms}$. col. INBA 209. el chismoso, óleo s/cartón, $98 \times 78 \mathrm{cms}$. col. Nieves-Bermúdez 210 . retrato de 
Antonio Martin, óleo s/tela, $95 \times 70$ cms. col. Nieves-Bermúdez 211. desnudo femenino, óleo s/tela, $180 \times 70 \mathrm{cms}$. col. Rodolfo Usigli 212. dos cabezas, óleo s/tela 49 x $37 \mathrm{cms}$. col. Rodolfo Usigli $A . N E F E R O$. Retrato de Manuel Rodríguez Lozano, 1946, óleo s/tela, $70 \times 95$ cms. col. Nieves-Bermúdez B. NEFERO. Retrato de Manuel Rodríguez Lozano, 1941, lápiz, 47 x $33 \mathrm{cms}$. col. Nieves-Bermúdez C. Modcsto Barrios. Retrato de Manuel Rodríguez Lozano, 1968, bronce, col. Nieves-Bermúdez $D$. Litografía de Pablo Picasso, dedicada a Manuel Rodriguez Lozano en 1920, $23 \times 29 \mathrm{cms}$. col. Nieves-Bermúdez E. Caballete de madera que utilizó el pintor Manuel Rodríguez Lozano, col. Nieves-Bermúdez.

EXPOSICIÓN HOMENAJE A AGUSTÍN LAZO. (1898-1971), PINTOR Y ESCENÓGRAFo. Presentada por el Instituto Nacional de Bellas Artes, Museo de Arte Moderno, Galería de Exposiciones Temporales. Planta Alta, el 8 de julio.

Agistín Lazo exquisito pintor, escenógrafo y escritor, fallecido el 28 de enero del presente año, nunca nos permitió (por exceso de prudencia) que le hiciéramos una exposición de sus obras en este Museo. Sin embargo, en nuestra conciencia pesaba esa deuda con el artista, siendo desafortunadamente para nosotros, el no haberle rendido el homenaje que merecía estando él presente y debiendo esperar hasta después de su muerte para poder satisfacer nuestros deseos y cumplir con esta obligación.

Las obras presentadas por el Teatro Orientación en los años 30 y 40 dirigidas por Celestino Gorostiza, tuvieron un gran significado en aquellos momentos, habiendo realzado su calidad y despertado mayor interés aún los vestuarios y escenografías realizadas por el pintor Agustín Lazo (así como en el Teatro Ulises lo hiciera la colaboración de otros tres grandes artistas: Roberto Montenegro, Manuel Rodríguez Lozano y Julio Castellanos).

Aun cuando no hemos reunido el total de sus obras, lo cual lamentamos profundamente, consideramos que las presentadas en esta ocasión sí son suficientes para que el público recuerde o conozca y admire al artista Lazo. Satisfechos de presentarlas en la Galería de Exposiciones Temporales en la planta alta del Museo de Arte Moderno, queremos hacer patente nuestro agradecimiento a su familia y a cada uno de los coleccionistas que tan gentilmente nos permitieron hacer posible esta exposición y han contribuido a que presentenos una de las más importantes realizadas en este Museo, en donde tratamos de hacer justicia a nuestros maestros artistas mexicanos.

\section{Fichas sin sobre para Lazo}

Agustín Lazo es un pintor de niños comestibles, maduros. Pintor de niños de más de veinte años, de niños de edad madura.

Como el poeta sus palabras, el pintor tiene sus útiles predilectos. El poeta sale a la calle y anota una frase trunca, un equívoco, un juego de palabras, un fragmento cle letrero que es casi un poema: Alto quintos ruedan vuelan. Lazo alarga los senticlos y roba un par de manos, un trozo de piso, una cortina, un niño. Luego en su taller, con ayuda de todo esto, inventa un cuadro.

Los niños se paralizaban de estupor delante de sus cuadros de niños. Era como si, inesperadamente, se hallaran frente a un espejo de tiempo, sin vivacidad, sin vitalidad, cumpliendo en un instante todos los años que habrán de cumplir en toda la vida. 
Juzgar a Lazo a la luz de los acontecimientos políticos de México -o de cualquiera otra parte- sería tin injusto como medir a Diego Rivera con el metro de la pintura pura.

Lazo fluisiera ser un pintor casi puro. En este casi cabe su ironía. Diego Rivera es un pintor que no quiere ser un pintor puro sino un dialéctico, un orador de la pintura. Los dos aciertan, cada uno a su manera.

Diego es un ruso oriental. Lazo, un europeo occidental.

Tazo: Diego Rivera: : Cocteau: Mayakovsky.

Virjes: Clirico. La escultura azteca. La pintura mexicana de pulquerías.

Los amigos de las analogías buscan en algunas de sus obras a Pablo Picasso. Lo encuenträl.

Frente a las mismas obras yo digo:

Me recuerdan Homero. Las manos, los ojos y los pies de los personajes de Honcro $y$, algunas veces, sus conversaciones.

J'iensa en francés, en inglés, en español, en italiano. ¿Cómo exigirle que no pinte cil esperanto?

Lazo pinta en esperanto. No hay en esto engaño alguno. Es tan claro que pinta en esperanto que esta misma evidencia nos da la clase. Ln cuadro de Lazo contiene a 1111 tiempo el texto y la traducción.

No es posible aún, felizmente, clasificar las telas de Lazo por épocas; unas antiairan olras; algunas, contradicen las precelentes. Todas tienen el temblor de un espíritu curioso, viviente.

Mas no falta quien pregunte: ¿en qué telas se halla el pintor?

Para algunos, en todas; pară todos, en ninguna.

Pintura para todos a condición de que todos sean unos cuantos.

Los suprarrealistas son los naturalistas del sueño. Pero aún no han producido un Germinal, ni siquiera un Zolá. Describir un sueño gráficamente lo hace un suprarrealista. Componer un cuadro con los elementos del sueño lo hace un pintor. Clirico es suprarrealista, pero no todos los suprarrealistas son pintores.

Un suprarrealista puede no ser un buen pintor. Un buen pintor es siempre suprarrealista. Un pintor de retablos describe un milagro. Un buen pintor lo ejecuta. Lazo liace entrar en una tela la alcoba de un sueño que parece que acaba de salir de un espejo, una escalera innprevista, una alfombra rococó y un retrato de mujer que es conno una figura de un primitivo. El público dice: tendencias encontradas. Pero el público no ha soriado numca o, cuando lia estado a punto de soñar, ha cerrado los ojos.

Frente al "carnicero" de Lazo, me decía convencido un amigo: "Yo lo he visto, lo lie visto cn algu11a parte". . Y yo, que sabía que éste era un cuadro invenuado totahmente, no estaba menos convencido de que mi amigo lo había visto rcalmente, $\mathrm{n}$ alguna parte: cu un sueño, por ejemplo.

Lazo pinta sin modelo aunque lo tenga enfrente. La realidad cercana, llena de inútiles detalles, lo distrae. Pinta de memoria, con los ojos cerrados y abiertos que usamos dirante el sueño.

La virtud de esta pintura es el puctor. Silenciosa e irónica, su ileal sería llegar a ser invisible, como la elegancia. Pudorosa y también incisiva, como la música de Eric Satie. La pintura de Lazo es tan calra como dos y dos son tres.

Lazo no teme los asuntos. Los burla con ironía y los reduce a pretexto. 
Me escribe: "No hay asuntos peligrosos, no hay ruinas ni máquinas. Cuando se tiene un sentido nuevo del mundo, las formas catalogadas vuelven a animarse".

\section{Paradojas de la modernidad}

Lo moderno no es el hormigón ni la máquina. Lo moderno sigue siendo el espuritu.

Me escribe Agustín Lazo: "En Italia lo más arcaico es el futurismo, y Paolo Ucello traduce la esencia de las máquinas mejor que un pintor actual."

Tiene tan desarrollado el sentido de la equidad que siempre responde a una pregunta con otra.

Sus dibujos tienen una gracia lenta, difícil, que no evita pero que tampoco procura entregarse.

En ni retrato por Lazo, lo menos viviente es la cara; siguen las manos, sigue la silla. Lo más viviente es el traje. Lazo no ama los objetos ni los cuerpos que dibuja. Ama simplemente el dibujo.

Yo lo he sorprendido como un nuevo Narciso dentro de la tinta - dentro de la fuente- contemplando una de sus telas como Narciso habría querido contemplarse: desde el agua hacia afuera.

No faltará literatura que diga que estas ficlias son literitura.

\section{Dos notas sobre Agustin Lazo}

Agustín Lazo nació en la ciudad de México el 28 de agosto de 1900. Antes de ingresar a la Academia de Bellas Artes fue discípulo del pintor Alfredo Rámos Martinez. Ya en la Academia asistió a las clases de Saturnino Herrán, a las que también concurrían Rufino Tamayo, Julio Castellanos, Fernández Ledesma y Francisco Díaz de León.

Insatisfecho ante la rutina escolar y cansado de ella, Agustín Lazo deja la Academia y se entrega, en la soledad de su esturlio, a cubrir por su cuenta y riesgo espirituales todos y cada uno de los pasajes que ha recorrido la pintura moderna en sus diversas trayectorias. Entonces pinta una serie de cuadros en los que ensaya la pintura de formas deshumanizadas, la pintura pura. Estos ensayos preparan y hacen posible, gracias a una lúcida depuración, la serie de cuadros de atrevidas formas plásticas, de inquietante contenido espiritual, que expone por primera vez en la ciudad de México el año de 1924.

Dos viajes por Europa: en 1922 el primero y en 1927 el segundo, le sirven para comprobar las ideas conquistadas en la soledad de su estudio y para enriquecer y acendrar las entrañas de un espíritu en que la pasión de la inteligencia se enlaza con una sensibilidad poética singular en la nueva pintura mexicana. Italia, Francia y parte de Alemania le brindan sus particulares lecciones, que Agustín Lazo recihe o recliaza con espíritu crítico.

De regreso a México, después de unos meses de trabajo, presenta en una segunda exposición prolongada, como también lo fue la prinnera, por quien esto escribe, la más inquietante $\mathrm{y}$ atrevida colección de dibujos que artista nexicano ha realizado.

Nunca la ventana de un cuadro mexicano se había abierto a realidades tan impre- 
vistas e inesperadas, unidas entre si por la colerencia sensible que liga el sueño de hoy con el de mañana.

No pertenece a esta dimensión inquietante del espiritu de Agustín Lazo el cuadro Niñas ejecutado para decorar uno de los salones de la Embajada de la República Española en México, sino a la no menos característica que revela un espíritu ordenado y armónico. Trazado vigorosamente, todos los puntos principales de la composición de este cuadro se hallan colocados dentro de los nudos armónicos resultantes de la intersección de los lados de dos pentágonos. Pintado con una limpieza y claridad notables, la materia adquiere una calidad preciosa, originada por el toque de pinceladas autónomas. $Y$ son un goce para los ojos las tierras rosas, el azul cerúleo $y$ el negro que juegan de modo admirable. Composición, materia y sentimiento de colores y formas, inteligencia, cuerpo y alma, hacen de este cuadro ya no un objeto plástico, sino un ser acabado y viviente.

Entre los nuevos pintores de México, Agustín Lazo es el de sensibilidad y cultivo más afinados. Sus cuadros son un buen espejo de su persona. Aquello que encontramos todavía en las telas de Rufino Tamayo, su compañero y su antípoda, ese "algo" que no podemos pasar sin un ligero daño, una pequeña espina de rigidez, de sistema, Agustín Lazo ha podido apartarlo con la naturalidad con que un buen gusto aparta, rechaza, y se queda, modesto y orgulloso, con unas cuantas cosas para ensayar con ellas un juego de formas tan fino que hasta el deliberado propósito de hacer arte parece encontrarse lejos.

Hay pintura elocuente, como hay música y poesía elocuentes. La pintura de Delacroix es elocuente si se la ve por el lado que no deberíamos ver jamás en su pintura. Por ningún lado de las telas de Lazo encontramos una sombra de elocuencia. También hay música incisiva y pudorosa a un solo tiempo, la música de Erik Satie. Esta pintura de Agustín Lazo es también pudorosa, incisiva. La encontramos lograda con el minimum de elementos y todos ellos claramente plásticos, y sin otra ambición que concurrir a una agradable reunión de formas y colores, a una pequeña sesión de voluptuosidad plástica.

Sin lección, sin historia, sin moral, estos cuadros de Agustín Lazo son el mejor ejemplo de una pintura desinteresada que conoce sus límites y sabe reducirse y vivir sólo dentro de ellos, cómodamente, sin excesos románticos, pero, al mismo tiempo, sin miserias ascéticas. Para un pintor que se propone la expresión plástica sintética, la presencia del modelo está llena de innecesarios detalles que desvirtúan la resolución elemental del cuadro. Agustín Lazo pinta, casi siempre, sin modelo, consonancia perfecta, intelectualista, que produce la misma impresión que una rima justa en un poema.

Los asuntos de sus telas están burlados irónicamente. También la realidad real. El pintor concede a las cosas, a las personas, la dimensión que conviene al papel que habrán de desempeñar en el total del cuadro. iQué nadie se acerque a esta pintura con una unidad métrica en los ojos!

No es la suya pintura lírica. Agustín Lazo no se deja vencer de la naturaleza, de la realidad, no se deja "vencer de Dios", sino hasta el punto en que la naturaleza, la realidad y Dios no rompen la organización plástica que se ha propuesto, y su sensibilidad.

Teorizante ha sido llanado alguna vez este pintor que ha recorrido el pasaje de la pintura de simples formas deshumanizadas. Su nueva colección de cuadros no es 
un cambio de rumbo sino un paso más armonioso y seguro, resultante de aquel ideal de sencillez y depuración que un día supo imponerse valientemente.

\section{Xavier Vill $\Lambda$ URrutia}

Agustin Lazo, pintor de lo subjetivo, por Alfonso de Neuvillate

La pintura, como la escultura, la música y la literatura alcanzaron el tono mayor y la trascendencia cuando se conjuntan talento, sensibilidad y lenguajes personales que obedecen al proceso histórico, político y social de la época, mismo que es asimilado y después devuelto en formas múltiples por esos espíritus finísimos que tienen algo importante que decir (imprescindible, diría yo) y lo manifiestan en el perfecto, preciso instante, en el momento en que es menester.

Alguna vez Justino Fernández escribió que: "No existe arte de transición, bien lo sabemos. Las épocas distintas producen buena o mala pintura, cuando no mediocridades. Sin embargo, es raro que en un periodo poco brillante no se encuentre el espíritu de renovación y las expresiones correspondientes." Certera afirmación ya que la obra de arte o es buena y de primer orden o sólo producto menor de los artistas, por consiguiente menores. El final del siglo XIX abunda en ejemplos notables poco conocidos, asimismo las dos décadas que siguieron al movimiento revolucionario poseen infinidad de pintores, hoy olvidados, cuya jerarquía y dimensión corresponde a las inquietudes por un lado nacionalistas y a las búsquedas personales alejadas de la objetividad radical del realismo de tipo historicista, mismas que concentraron, paradójicamente, los derroteros subjetivos de esa extraña amalgama de poesía con especulación con los tonos de lo cotidiano y lo sutil del embrujo nostálgico.

Esta serie de artistas personales, que en determinada ocasión fueron peyorativamente considerados y etiquetados como "afrancesados" devinieron obras singularísimas que, además de su calidad expresamente pictórica, tuvieron el valor de seguir rumbos opuestos a la franca dictadura de la pintura socialista de la Escuela Mexicana.

Los temas vernáculos, las formas humanas y zoológicas y aun las vegetales que no existen en la realidad, la precisión al plasmar detalles del gozo de la vida, miniaturales reflejos sensitivos y sensuales de la fantasía y la imaginación desbordada, o por lo contrario, la descripción de temas alegóricos, casi elegíacos, cuyo origen estriba en la concepción dionisíaca y apolínea de la vida común y corriente hizo que esos artistas se elevaran a una categoría metafísica casi inalcanzable para el grueso de los espectadores pero que, su resonancia todavía fascina por su problemática y sus efemérides poéticas que sólo los poetas han alcanzado en trazos literarios.

Así como Valéry trabajó en subjetivos y complicados laberintos de la magia poética en el Cementerio Marino, así como Jean Cocteau proponía el retorno a las figuraciones extravagantes de lo milagroso y lo extra natural; como José Juan Tablada retornaba a las formas del Hai-Kai (telegramas poéticos al decir de Gómez de la Serna) y a los ideogramas, casi al mismo tiempo que Apollinaire; los pintores mexicanos solitarios, apartados del gran sismo que fue el muralismo y su descendencia en pintura anecdótica y superficial-folklorista llevaron al cabo edificaciones estéticas muy valiosas porque son, en su radical expresión la búsqueda del tiempo por medio de lo intemporal; la imagen por la imagen misma y lo que se desprende de 
ella, la poesía que no es poesía sino relámpago de sensaciones y puerta abierta a la comunicación.

El espíritu sagaz de Xavier Villaurrutia expresó: "Agustín Lazo nació en la ciudad de México el 28 de agosto de 1898. Antes de ingresar a la Academia de Bellas Artes fue discípulo de Alfredo Ramos Martinez. Ya en la Academia, asistió a las clases de Saturnino Herrán, a las que también concurrian Rufino Tamayo, Julio Castellanos, Fernando Ledezma y Francisco Díaz de León. Insatisfecho ante la rutina escolar y cansado de ella, Agustín Lazo deja la Academia y se entrega cula soledad de su estudio, a cubrit por su cuenta y riesgo espirituales, todos y cada uno de los pasajes que ha recorrido la pintura moderna en sus diversas trayectorias. Entonces pinta una serie de cuadros en los que ensaya la pintura de formas deshumanizadas, la pintura pura. Estos ensayos preparan y hacen posible, gracias a una lúcida depuración, la serie de cuadros de atrevidas formas plásticas, de inquietante contenido espiritual, que expone por primera vez en la ciudad de México el año de 1924 ... Nunca la ventana de un cuadro mexicano sc había abierto a realidades tan imprevistas e inesperadas, unidas entre sí por la coherencia sensible que liga el sueño de hoy con el de mañana" (Galeria de Pintores Modernos Mexicanos Na 4, 1934.)

En efecto, las obras de Lazo resultaban novedosas por su finísina :manera de sintetizar las formas extraidas a lo más refinado de las emociones ticrnas y por su tcmática en sí: gatos, retratos espirituales, caballos, saltimbanquis, redondeces sensuales del cuerpo masculino y femcnino, detalles ninuciosos de la vida contemplativa así como asombrosas relaciones de imágenes disimbolas confundidas en el fondo cromático espatulado o aquel otro semejante al de los puntillistas europeos.

Lazo supo encauzar el intelectualismo por los senderos fantásticos de la pintura extra-real, con lo cual se hermana con los simbolistas y con los artistas descriptivos del sovoir-faire, de la alegría de dicho a propósito en tono capricloso y con las narraciones literarias y las musicales de los creadores alemanes, franceses e italianos de los veintes.

Junto con Julio Castellanos, liederico Cantí, Frida Kalılo, Carlos Mérida y Gunther Gerzso, Agustín Lazo conforma una verdadera cosmogonía de rcbeldes de la pintura. Así como Manuel Rodríguez Lozano sc apartó de las estipulaciones mexicanistas de los "tres grandes", posteriormente habían de seguirle otros artistas de primera línea que, habiendo asimilado todas las especulaciones, inventos y significados del arte féerico y exhaustivo de la Europa contemporánea, consolidaron obras singularísimas que dependían exclusivamente del orden poético y la jerarquía del ensueño.

Agustín Lazo, como Juan Soriano y tantos más, son pintores indescriptibles. Su obra es lo que indica sus preocupaciones reales y los inventos del onirismo. La pintura mejor de todos los tiempos es la que se significa mediante el simbolo y la simbología del signo. Su radical puede ser la belleza natural o la otra que colinda con los límites de la fantasia y aun de la metafísica.

Lazo es el arte que deja de serlo al momento del análisis: trascicnde la limitación del lenguaje por ser, asimismo, lenguaje de extraordinaria factura. Esa granática posee sus propias reglas: sintaxis en forma de parábolas existenciales.

La hermosura de, por ejemplo, los gatos que reposan, de los que pelean fieramente, de los otros que desplazan al spleen en cojines lujuriosos, o bien de los caballistas 
que, inesperadamente caen de su montura, en el asombro y ío insólito, a ras esculturas en medio de acueductos o paisajes poco reconocibles, son gamas circunstanciales de acepción en los logros del maestro Lazo, pintor de las paradojas y de lo que puede ser o no en la realidad y en el invento.

A partir de lo insólito, de lo que sucede sólo en el cuadro, de lo que concibe la imaginación, la obra de Lazo va abriendo puertas secretas. Especie de llave milagrosa con la cual nos transportamos al mundo ideal, pero paradójico y axiomático, de la recreación nostálgica.

Hegel exigía del arte mucho más que la representación verista de los objetos. Los artistas inventan esa realidad y adquiere categoría estética según es el significado y los vuelos imaginativos del hacedor de las emociones. Agustín Lazo concretiza lo abstracto $y$ hace abstracción de la realidad. De hecho, toda actividad plástica es abstracción mental, tan descabellada como el invento de una forma literaria a la ideografía de ciertas poesías eróticas.

Agustín Lazo es virtuoso del refinamiento. Sus obras son logros en donde no fuede hacerse el deslinde entre lo que es dibujo, pintura o mero trazo superficial. Ln cada una de sus pinturas cuenta el enigma y los misterios que se deducen de él. Hace transposiciones entre el paraíso del poeta con las luces artificiales de los cuartos intimistas: habitaciones cerradas por el secreto y la expectativa teatral.

Estos misterios viven, mueren, tienen significado efímero dentro de los otros significados críticos de las imágenes cifradas. Todos los seres que él ha plasmado en los lienzos, sirenas, payasos, centauros, etcétera, son ideas distantes, puesto que su realización es su radical poética. Casi transparentes, inanimadas, fuera de lo cotidiano, como títeres pequeñísimos que se contemplan en el insomnio, en la calle, en la inultiplicación obsesionante de la ensoñación son sus pinturas asombrosas. La razón produce monstruos y alucinaciones. El lombre inteligente, en especial el artista, les rla forma dentro de las nil formas de la ternura y la poiesis. Agustín Lazo es pintor infinista, difícil de atrapar en las invocaciones literarias, asimismo, un caso aislado de creatividad y esfuerzo por no sucumbir ante lo esencialmente narrativo. El cuento de la narración da resultados contraproducentes. Lazo concluyó en el silencio al ya no tener absolutamente nada que decir. El dijo todo, por ser poeta y narrador. Sus invocaciones revelaban las motivaciones intrínsecas de su amor al arte y las formas desprendidas del concepto. Su método fue el único y singular: recreación de veleidades y deseos, satisfacciones y retroactivas formas de la subjetividad.

Las concomitancias, correspondencias estéticas existentes entre las obras de Lazo, Rodriguez Lozano, Julio Castellanos, María Izquierdo, Alfonso Michel, Tebo y Federico Cantú son, en el mundo de lás ideas, las mismas que existen entre las obras literarias de los contemporáneos (el grupo sin grupo).

No en balde el que mejor supo descifrar los secretos escondidos en la plástica de Agustín Lazo fue Xavier Villaurrutia, mismo que precisó el justo valor del artista dentro de la jerarquía de los creadores sui-géneris.

En el análisis detenido, profundo y no superficial, la obra pictórica que me ocupa adquiere la exacta dimensión de los poetas señalados: Novo, Cuesta, Owen, Villaurrutia. Su antagonismo frente a ciertas gradaciones del nacionalismo los hizo aparecer como anacrónicos dentro de los frutos óptimos que concebía al arte nacional.

Sin embargo, el andamiaje en que se sustentan estos trabajos posee significado poco frecuente en las obras de imaginación: las presencias evocan ausencias, lo in- 
confesable toma rango misterioso: el recuerdo queda confundido entre verdad y mentira.

E1 poeta mayor que es Agustín Lazo creó pinturas sin fecha, intemporales, ejercicios fantásticos de alternación de valores conocidos con los de la vigilia fantástica y con las otras del orden cósmico.

Este conjunto, constelación de pintores sin runbos definidos, sin preciosos horizontes, casi sin técnica perfecta, muy por el contrario, con reiteraciones con improvisados medios de satisfacer su necesidad emocional, con instintiva tendencia a lo cotidiano, las concretó en voceros del objeto artístico que, por la lucidez y sentimiento, son "seres acabados y vivientes"; grandilocuencias de la insatisfacción y unidades coherentes del pensamiento mágico y lo cual del signo subjetivo.

Agustín Lazo esbozó la astronomía del cielo romántico: sus cuadros quieren ser retratos de niñas tristes, de adolescentes que uno conoce en el sueño $y$ en la inmensidad del pensamiento, y el presentimiento asombroso: la dualidad de cada personaje nos hace meditar en lo efímero de la vida mediata y la profundidad eterna $\mathrm{y} \sin$ fin de la muerte.

A la reflexión llega la duda y también la solución de lo perfecto: puede o no ser lo que el pintor pretendió decir en su obra, no importa; lo que en verdad cuenta es la forma en que dijo su verdad y sus aproximaciones al reino de lo intangible y lo incatalogable.

El gran teatro de la vida es la representación poética pictórica de Agustín Lazo. Representación mental y por tanto abstracción. Entre las bambalinas y los telones imaginarios del laberinto en clonde se especula con artificiales sintomas de lo bello y lo maravilloso.

En los enigmas, en los jeroglíficos simplificados que pinta o pintó, estribaban sus ligas con la gran tradición de la pintura que narra ocasiones de júbilo y tristeza. Empero, el aire sombrío, la profundidad irreductible de los elementos opuestos es lo que engendra nuevos axiomas y nuevos misterios y es lo que coloca a Agustín Lazo y a Julio Castellanos dentro del orden de valores cuyo empeño es mostrarnos lo real de lo bello y la trascendencia de lo corriente.

En 1966 escribi una monografía sobre la pintura actual (de aquel entonces) de México. En ella no encontré los pintores que considero fundamentales en la evolución artística del país. Seleccioné a 35 artistas de muy diversas expresiones y tendencias para confirmar el aserto de que una Escuela se sustenta en la multiplicidad de manifestaciones estéticas. Quizá ahora sólo escogería a cinco o seis y la complementaría con Lazo, Castellanos, Rodríguez Lozano, Frida Kahlo, María Izquierdo, Jesús Guerrero Galván, Gunther Gerzso y tal vez Guillermo Meza y otros más.

Mucho más importante y trascendente es la obra de Lazo y Gerzso y Mérida que la de muchos jóvenes aventurados en el camino de la nada y su obsecación en seguir los dictados de Nueva York. Más profundo es lo que reflexiona Rodríguez Lozano que lo que dicen las obras quinéticas de hoy.

Más racionales son las premisas inconclusas del silogismo pictórico que lanzaron Lazo y Castellanos que el propósito de confundir con las naciones vanguardistas -o supuestamente vanguardistas- de ciertos ismos y ciertos istas.

Cardoza y Aragón expresó que: "Agustín Lazo es el menor pintor de los pintores mexicanos. Sus mejores obras (las que así considero) son aquellas que están en oposición a la pintura de México. En ellas no sólo es ajeno, sino liostil a tales 
fornas animadas por retórica, esa mala embalsamadora. Agustín Lazo pinta anécdotas, lo que se quiera, arte impersonal, invisible como el aire. No es poco lo que representa entre el grupo de pintores personalísimos de México. Por su impersonalidad es inconfundible... Sus buenas obras son poentas. Sus poemas son buena pintura."

Por tales efectos me duelo de no haber incluido a estos artistas, con Lazo al frente, en el libro que señalé. De haber aquilatado su producción, con sus correspondencias en la historia, la política del arte y el arte politizado, con sus logros indiscutibles y con su profesión de fe por el arte de la duda y el misterio, mis conclusiones hubieran sido otras muy distintas de las que extraje en esa oportunidach.

Sin estos adelantos - pioneros de la expresión subjetiva- el arte mexicano de hoy sería muy diferente al cual es en realidad. Estos puentes que estipularon, técnica y cromáticamente, desde los veintes, condujeron a satisfacer el encuentro poético con la reflexión y la abstracción del mundo a nostalgia y perfección estilista.

Agustín Lazo, un pintor extraordinario que dejó de producir belleza por razones que no entiendo. Su proyección es mayor al sentir sus profundidades y sus límites de belleza, un gran artista del cual ir radian múltiples subjetivismos actuales. Pintura del poeta comprometido ante la poesía pura y su consecuencia que es el arte en sus infinitas posibilidades.

Los datos biográficos de Agustín Lazo son limitados, como escasa su producción. Nació en México, D. F., en 1898 en donde hizo estudios prinıarios y superiores. En 1917 ingresó en la Escuela de Artes Plásticas teniendo como compañeros a Rufino Tamayo, Francisco Díaz de León, Abelardo Carrillo y Gabriel Fernández Ledeznna. Viajó a Europa desde 1922 donde permaneció hasta 1932 (con un intermedio regresó al país en 1925). En París frecuentó la Grande Chaumiére y ahí realizó no pocas obras de caballete con su peculiar finura. En 1934 expuso por vez primera en un local de la avenida Madero y después, en 1935, en otro local de la avenida Juárez. Se destacó como escenógrafo para el grupo de Teatro Orientación. Además, cabe mencionar sus trabajos como ensayista, literato y fundamentalmente como poeta. Sus pinturas, sin ser vastas, destacan en el arte mexicano del siglo xx.

Catálogo: Acuarelas para vestuario de diferentes obras de teatro: 1. ejecución interrumpida, $26.5 \times 37 \mathrm{col}$. de la Sra. Inés Amor 2. invitada I, $21 \times 14 \mathrm{col}$. de la Sra. Ma. Luisa Lazo Vda. de García 3. invitada $I I, .21 \times$ x .14 col. Sra. Ma. Luisa Lazo Vda. de García 4. invitada III (firmada), .21 x .14 col. Sra. Ma. Luisa Lazo Vda. de García 5. baronesa $I$, .21 x .14 col. Sra. Ma. Luisa Lazo Vda. de García 6. baronesa II, $21 \times .14$ col. Sra. Ma. Luisa Lazo Vda. de García 7. Elena, .21 x .14 col. Sra. Ma. Luisa Lazo Vda. de García 8. anaris, . $21 \times .14 \mathrm{col}$. Sra. Ma. Luisa Lazo Vda. de García 9. Virginia .21 x .14 col. Sra. Ma. Luisa Lazo Vda. de García 10. Clara (firmada), 21 x .14 col. Sra. Ma. Luisa Lazo Vla. de García 11. Héctor (firmada), $.25 \times 16.5$ col. Sra. Ma. Luisa Lazo Vda. de García 12. Ulises (firmada), $25 \times 16.5$ col. Sra. Ma. Luisa Lazo Vda. de García 13 al 20. sin títulos ( $\sin$ firmar) de $.28 \times .1921$ al 28 . sin títulos (firmadas) de $.28 \times .1929$ al 35 . sin títulos (sin firma) de $27 \times 18.5 \quad 36$ al 39 . sin titulos (firmadas) de $.27 \times 18.5$ 40. De la obra La Hostelera de Goldini: Mirandolina, 32.8 × .24 col de la Sra. Ma. Luisa Lazo Vda. de Garć́a 41. De la obra La Hostelera de Goldini: Caballero de Rocatallada, $32.8 \times .24$ col. Sra. Ma. Luisa Lazo Vda. de García 42. de la obra La Hostelera de Goldini: Dayamira, $32.8 \times 24$ col. Sra. Ma. Luisa Lazo Vda. de García 43 al 45. sin títulos (firmadas), de 33.7 × 24.6 col. Sra. Ma. Luisa Lazo Vda. de García 46 al 50. sin título (firma- 
(a), de 24.6 × 33.7 col. Sra. Ma. Luisa Lazo Vda. de García 51 al 52. sin título (firmadas), dos figuras, de $26.8 \times 36.9 \mathrm{col}$. Sra. Ma. Luisa Lazo Vda. de García 53. sin título (firmada $c /$ tres figuras), de $26.8 \times 36.9 \mathrm{col}$. Sra. Ma. Luisa Lazo Tla. de García 54. Celemene (firmada), 27.4 x 17.8, col. Sra. Ma. Luisa Lazo Vda. de García 55. Alsate (firmada), 27.4 x 17.8, col. Sra. Ma. Luisa Lazo Via de García 56. Clitendre, 27.4 x 17.8 col. Sra. Ma. Luisa Lazo Vda. de García 57. Cosme, $27.4 \times 17.8$ col. Sra. Ma. Lazo Vda. de García 58. Thilinte, $27.4 \times 17.8$ col. Sra. Ma. Luisa Lazo Vda. de García 59. Izarde, 27.4 x $17.8 \mathrm{col}$. Sra. Ma. Luisa Lazo Vila. de García 60. bosque, $27.4 \times 17.8$ col. Sra. Ma. Luisa Lazo Vla. de García 61. Moussican, 27.4 x 17.8 col. Sra. Ma. Luisa Lazo Vda. de García 62. sin título, $30.3 \times 20.8 \mathrm{col}$. Sra. Ma. Luisa Lazo Vda. de Garcín 63. sin título, $30.3 \times 20.8 \mathrm{col}$. Sra. Ma. Luisa Lazo Vda. de García 64. sin título, $30.3 \times 20.8$ col. Sra. Ma. Luisa Lazo Vda. de García 65. Tousineré (firmada). $27.4 \times 17.8 \mathrm{col}$. Sra. Ma. Luisa Lazo Vda. de García 66. pescados, $1952, .35 \times 2.6$ col. particular ACUARELAS PARA VESTUARIO: 67. Ifigenia cruel de lit obra de Alfonso Reves, s/f. vestuario Ifigenia $23.5 \times 32.5$, col. Sra. Clementina Otero de Barrios 68. Ifigenia cruel de la obra de Alfonso Reyes, s/f, vestuario soldado, $.24 \times 32.5 \mathrm{col}$. re la Sra. Clementina Otero de Barrios 69. Ifigenia crucl (le la obra de Alfonso Reyes, s/f, vestuario soldado .24 x 32.5 col. Sra. Clementina Otero de Barrios 70. Ifigenia cruel de la obra de Alfonso Reyes, s/f, vestuario Orestes $23.5 \times 32.5 \mathrm{col}$. Sra. Clementina Otero de Barrios 71. Ifigenia cruel de la obra de Alfonso Reyes, s/f, coro hombres, $23.5 \times 32.5$ col. Sra. Clementina Otero de Barrios 72. Ifigenia cruel de la obra de Alfonso Reyes, $s / f$, vestuario pastor .24 x.32 col. Sra. Clementina Otero de Barrios 73. Ifigenia cruel de la obra de Alfonso Reves, s/f, $23.5 \times 32.5 \mathrm{col}$. Sra. Clementina Otero de Barrios 74. restuario para la obra de Molière $.45 \times .35$ col. del Sr. Abelardo y Colón 75 . mujeres cosiendo, 1935, .22 x.29 col. Sr. Alfredo Cornejo 76. de la obra La Mulata de Cordoba, diseño de vestuario, $32.6 \times .25$ col. Depto. Técnico de Espectáculos del TNBA 77. de la obra La Mulato de Córdoba, diseño de vestuario, $32.4 \times 20$ col. Depto. Técnico de espectáculos del INBA 78. de la obra de Ballet La Mulata di Córloba, Inquisidor, $34.2 \times .25 \mathrm{col}$. Depto. Técnico de Espectáculos del INBA 79. cle la obra de ballet La Mulata de Córdoba, Alguacil, .34 x 24.6 col. Depto. Técnico (le Espectáculos del INBA 80. de la obra de Ballet, La Mulata de Córdoba, Aureliv, $34 \times 24.6$ col. del Depto. Técnico de Espectáculos del INBA 81 y $81 \mathrm{~A}$. De la olra de ballet, La Mulata de Córdoba, vecina I y vecina II, $.34 \times .25$ col. Dento. Técnico de Espectáculos del INBA 82. de la obra de ballet, La Mulata de Córdoba !er. enamorado, $.37 \times .25$ col. Depto. Técnico de espectáculos del INBA 83. de la obra de ballet, La Mulata de Córdoba, enamorado, $.34 \times .25$ col. Depto. Técnico de erpectáculos del INBA 84. de la obra de ballet, I. a Mulata de Córdoba F. St. Oficio, $.34 \times .25 \mathrm{col}$. Depto, de Espectáculos del INBA 85 . de la obra de ballet, $L a$ Mulata de Córdoba, vecino, $.34 \times .25$ col. Depto. Técnico de Espectáculos del INBA 86. de la obra de ballet, La Mulata de Córdoba, Anselmo, .34 x .25 col. Depto. Técnico de espectáculos del INBA 87. de la obra de ballet Antigona Mensajero, .33 x .24 col. Depto. Técnico de espectáculos del INBA 88. de la obra de ballet. Antígona Paje, $34 \times .25$ col. Depto. Técnico de espectáculos del INBA 89. de la obra de ballet. Antígona coro, $32 \times .24$, col. Depto. Técnico de espectácilos del INBA. 90. de la obra de ballet Antígona Nodriza, $33 \times .24$ col. Depto. Técnico de espectáculos del INBA 91. de la obra de ballet Antígona Herión, $34.5 \times 25$ col. Depto. Técnico de espectáculos del INBA 92. de la obra de ballet, Antígona Ismenia, $.35 \times .23$ col. Depto. Técnico de espectáculos del INBA 93 . de la obra de hallet, Antigona Eurídice, $.33 \times .24$ col. Depto. Técnico de espectáculos del INBA 94. re la obra de ballet Antigona Guardias, $33.3 \times .22 \mathrm{col}$. Depto. Técnico de Espectáculos del INBA 95. boceto de escenografía, $21.5 \times 28.7$ col. Depto. Técrico de Espectáculos del INBA 96. boceto escenografía, $26.5 \times 33.5$ col. Depto. Técnico de Espectáculos del INBA 96A. vest. p/teatro orientación, col. Sra. Paloma G. Socaya 96B. figura de hombre sentado en sofá $27 \times 35.5 \mathrm{col}$. Sra. Mercedes P. de Ruiz 07. herramicnta Omega, 26.8 × $36.8 \mathrm{col}$. Sra. Ma. Luisa Lazo Vda. de García 98. I.cdas Alfa, $26.8 \times 36.8 \mathrm{col}$. Sra. Ma. Luisa Lazo Vda. de García 99. mujer, niño 
y gato, $37.3 \times 27.7$ col. Sra. Ma. Luisa Lazo Vda. de García 100. seis figuras, $24.5 \times 33.3$ col. Sra. Ma. Luisa Lazo Vda. de García CRAYÓN A COLOR: 101. caserio y arboleda ( $\sin$ firma), $.27 \times .37$ col. Sra. Ma. Luisa Lazo Vda. de García 102. boceto de gato, $32.2 \times 23.4 \mathrm{col}$. Sra. Ma. Luisa Lazo Vda. de García 103. gato sentado, $32.2 \times 23.4$ col. Sra. Ma. Luisa Lazo Vda. de García 104. cara de gato, $32.2 \times 23.4$ col. Sra. Ma. Luisa Lazo Vda. de García 105. cara de perfil, $32.2 \times 23.4$ col. Sra. Ma. Luisa Lazo Vda. de García 106. mujer acostada, $32.2 \times 23.4$ col. de la Sra. Ma. Luisa Lazo Vda. de García 107. sin titulo, $17.8 \times 11.8$ col. Sra. Ma. Luisa Lazo Vda. de García 108. sin título, $32.2 \times 23.4$ col. Sra. Ma. Luisa Lazo Vda. de García 109. sin título, $32.2 \times 23.4$ col. Sra. Ma. Luisa Lazo Vda. de García 110. sin título, $32.2 \times 23.4 \mathrm{col}$. Sra. Ma. Luisa Lazo Vda. de García DIBUJOS A LAPIZ SOBRE CARTON: 111. retrato de Luis Cardoza y Aragón, col. Sr. Luis Cardoza y Aragón 112. mujer con caballo (firmado), .12 x.18 col. Sra. Ma. Luisa Lazo Vda. de García 113. niños peinándose (proyecto de óleos), $.20 \times .25$ $\mathrm{s} /$ papel manila, col. Sra. Ma. Luisa Lazo Vda. de García 114. niños en la escruela (proyecto de óleos), .20 x.25 s/papel manila, col. Sra. Ma. Luisa Lazo Vda. de García 115. Ledas Alfa, 32 x 23.4 col. Sra. Ma. Luisa Lazo Vda. de García 116. mano, $.32 \times 23.4$ col. Sra. Ma. Luisa Lazo Vda. de García 117. sin título, $32 \times$ 23.4 col. Sra. Ma. Luisa Lazo Vda. de Garcia 118 . herramientas Omega, .32 x 23.4 col. Sra. Ma. Luisa Lazo Vda. de García 119. centro de oro. $29 \times 22.7$ col. Sra. Ma. Luisa Lazo Vda. de García 120 . hombre con lentes, $28 \times .22 \mathrm{col}$. Sra. Ma. Luisa Lazo Vda. de García 121. dos manos, 32 x 34.8 col. Sra. Ma. Luisa Lazo Vda. de García 122. piernas, 32 × $34.8 \mathrm{col}$. Sra. Ma. I uisa Lazo Vda. de García 123. piemas con torso, .32 x $34.8 \mathrm{col}$. Sra. Ma. Luisa Lazo Vda. de García 124. ficrna crusada, $.32 \times 34.8 \mathrm{col}$. Sra. Ma. Luisa Lazo Vda. de García 125. torso cruzado al frente, 32 x $34.8 \mathrm{col}$. Sra. Ma. Luisa Lazo Vda. de García 126. pie y cara .32 x 34.8 col. Sra. Ma. Luisa Lazo Vda. de Garcia 127. torso de mujer, $.32 \times 34.8$ col. Sra. Ma. Luisa Lazo Vda. de García 128. torso de mujer con las manos cruzadas, $32 \times 34.8$ col. Sra. Ma. Luisa Lazo Vda. de G. 129. desnudo de espalda con picrna flexionada, $.32 \times 34.8 \mathrm{col}$. Sra. Ma. Luisa Vda. de G. 130 . muchacha desmuda sentada, $.32 \times 24.8$ col. Sra. Ma. Luisa Lazo Vda. de García 131. retrato de Antonio Magaña Esquivel, dibujo a pluma, .27 x.21 col. Sr. Antonio Magaña Esquivel 132. pareja, dibujo acuarelado, $32.4 \times .23 \mathrm{col}$. Sr. Lic. Alfonso Noriega y Sra.: ESCENOGRAFIAS 133. de la obra de J. Cocteau Antígona, .28 x.37 col. Sra. Clementina Otero de Barrios 134. de la obra de Celestino Gorostiza Escombros de un sueño, $.28 \times .37$ col. Sra. Clementina Oteto de Barrios 135. de la obra de Alfonso Reyes Ifigenia Cruel, $.8 \times .37 \mathrm{col}$. Sra. Clementina Otero de Bartios 136. de la obra cle Lenormand $A$ la sombra del mal. s/f $.28 \times .37$ col. Sra. Clementina Otero de Barrios 137. de la obra de Molnar Jilión. $28 \times .37 \mathrm{col}$. Sra. Clementina Otero de Barrios 138. de la obra de Molnar Jilión, .28 x .37 col. Sra. Clementina Otero de Barrios 139. sin título. 27.5 × $3.5 \mathrm{col}$. Sra. Ma. Luisa Lazo Vda. de García 140. una petición de mano, $.19 \times .29$ col. Sra. Ma. Luisa Lazo Vda. de García 141. sin titulo, $22.2 \times .31 \mathrm{col}$. Sra. Ma. Luisa Lazo Vda. de García 142. Minie la cándida, $25.4 \times 35.2 \mathrm{col}$. Sra. Ma. Luisa Vda. de García 143. el burgués gentilhombre, 25.8 × $36.4 \mathrm{col}$. Sra. Ma. Luisa Lazo Vda, de García 144. la amiga de las mujeres, $25.9 \times .36$ col. Sra Ma. Luisa Lnzo Vda. de García 145. la hiedra, $.25 \times 36.8$ col. Sra. Ma. Luisa Lazo Vda. de García 146. el burgués gentilhombre, .26 x .36 col. Sra. Ma. Luisa Lazo Vda. de García 147. Orfeo, $26.3 \times 37.6 \mathrm{col}$. Sra. Ma. Luisa Iazo Vda. de García 148, sin título, $21.6 \times .30$ col. Sra. Ma. Luisa Lazo Vda. de García 149. sin título, $18.8 \times 26.8 \mathrm{col}$. Sra. Ma. Luisa Lazo Vda. de García 150. sin título, $18.4 \times 26.8$ col. Sra. Ma. Luisa Lazo Vda. de García 151. sin título, $24.6 \times .24$ col. Sra. Ma. Luisa Lazo Vda. de García 152. sin título, $24.8 \times 20.7$ col Sra. Ma. Luisa Lazo Vda. de García 153. sin título, $24.7 \times 22.3$ col. Sra. Ma. Luisa Lazo Vda. de García 154. sin título, $21.5 \times 23.2$ col. Sra. Ma. Luisa Lazo Vda. de García 155. sin título, $21.5 \times 22.2 \mathrm{col}$. Sra. Ma. Luisa Lazo Vda. de García 156. sin título, $20.5 \times 22.8$ col. Sra. Ma. Luisa Lazo Vda. de García 157, sin título, $20.7 \times 19.7$ col. Sra. Ma. Luisa Lazo Vda. de García 158. sin título, $20.9 \times .19$ col. Sra. Ma. Luisa Lazo Vda. de García 159. sin título, $20.2 \times .19$ col. Sra. Ma. Luisa 
Lazo Vda. de García 160. sin título, $18.5 \times .21$ col. Sra. Ma. Luisa Lazo Vda. de García 161. sin título, 17.5 x.19 col. Sra. Ma. Luisa Lazo Vda. de García 162. sin título, 21.7 x 15.5 col. Sra. Ma. Luisa Lazo Vda. de García 163. sin tîtulo, $19.5 \mathrm{x}$ .13 col. Sra. Ma. Luisa Lazo Vda. de García 164. Chimalixtac (firmado), $.25 \mathrm{x}$ 32.3 grabado, col. Sra. Ma. Luisa Lazo Vda. de García DIBUJOS A LAPIZ SOBRE PAPEL: 165. panteón, $.19 \times .23$ col. Sra. Ma. Luisa Lazo Vda. de Garcia 166. retrato, $.22 \times 18.5 \mathrm{col}$. Sra. Ma. Luisa Lazo Vda. de Garcia 167. retrato, $.47 \times 33$ col. Sra. Ma. Luisa Lazo Vda. de García 168 . mujer de ojos verdes, $.50 \times$ .40 col. Sr. Abelardo Carrillo y Colón OLEOS: 169. el niño de la pelota, 1925, óleo s/tela $.50 \times .40 \mathrm{col}$. Sra. Inés Amor, directora de la Galería de Arte Mexicano 170. caballo, óleo s/tela, col. Sra. Gabriela Almada de Ballesteros 171. el perro, 1952, óleo s/tela, $.56 \times .41$ col. Sra. Ma. de Gadsky 172. las botellas, 1923, óleo s/tela . $54 \times 47.5$ col. Sra. Ma. de Gadsky 173. los caballos, óleo s/tela, $.56 \times 40.5$ col. Sra. Margot Glantz 174. robo al banco, $27 \times 36.5$ col. Sra. Ma. Luisa Lazo Vda. de García 175. juego de pelota, $34.8 \times 23.6 \mathrm{col}$. Sra. Ma. Luisa Lazo Vda. de García 176. fusilamiento, 24.2 ×.33 col. Sra. Ma. Luisa Lazo Vda. de García 177. entrada al misterio, $26.4 \times 36.6$ col. Sra. Ma. Luisa Lazo Vda. de García 178 . el joven de las manos, 34.3 x 26.8 o.s.t. col. Sra. Ma. Luisa Lazo Vda. de García 179. los amigos, 34.2 x 26.8 o.s.t. col. Sra. Ma Luisa Lazo Vda de García 180 . cabeza de joven, .56 x .50 o.s.t. col. Sra. Ma. Luisa Lazo Vda. de García 181, el guajolote, $45.8 \times 7.5$ o.s.t. col. Sra. Ma. Luisa Lazo Vda de García 182. las piñas, $.75 \times .45$ o.s.t col. Sra. Ma. Luisa Lazo Vda de García 183. retrato de mi madre, óleo s/tela, $41.5 \times 41.4$ col. Sra Ma. Luisa Lazo Vda. de García 184. paisaje, óleo s/tela, $.80 \times .90$ col. Sr. Carlos Luquín 185. la familiada, óleo s/masonite, $.27 \times 36.5$ col. Sra. Guadalupe Marín 186, en la escuela, óleo s/tela, $1.21 \times .97$ col. del INBA 187. niños con jaula, óleo s/tela, $1.21 \times .97$ col. INBA 188. cabeza, $.48 \times .37$ óleo s/cartón col. INBA 189. interior con piano, óleo s/tela, .64 x.47 col. Sr. Jaime Saldivar 190. madre naturaleza, óleo s/tela, 60 x 60 col. Sr. Guillermo Sánchez Lemus 191. figuras en la playa, óleo y pincel, .26 x.36 col. Sra. Paloma G. de Sosaya 192. retrato le Xavier Villarrutia, óleo s/tela, $.70 \times 70 \mathrm{col}$. Srita. Teresa Villaurrutia 193. el dibujante, óleo y tinta s/papel, .36 x .27 col. Srita. Teresa Villaurrutia 194. la eterna despedida, óleo y tinta s/papel, $.35 \mathrm{x}$ $.24 \mathrm{col}$. Srita. Teresa Villaurrutia SECCION SURREALISTA : (Montajes de grabados) 195. sin título, $14 \times 21.8 \mathrm{col}$. Sra. Ma. Luisa Lazo Vda. de García 196. sin título, $14 \times 22.6 \mathrm{col}$. Sra. Ma. Luisa Lazo Vda. de García 197. sin título, $.23 \mathrm{x}$ 13.5 col. Sra. Ma. Luisa Lazo Vda. de García 198. sin título, $15.8 \times 23.3$ col. Sra. Ma. Luisa Lazo Vda. de García 199. sin título, $15.5 \times 22.5 \mathrm{col}$. Sra. Ma. Luisa Lazo Vda. de García 200. sin título, $15.8 \times .22$ col. Sra. Ma. Luisa Lazo Vda. de García 201. sin título, $15.2 \times 22$ col. Sra. Ma. Luisa Lazo Vda. de García 202. sin título, $15.5 \times .22$ col. Sra. Ma. Luisa Lazo Vda. de García 203. sin título, $16.5 \mathrm{x}$ 22.5 col. Sra. Ma. Luisa Lazo Vda. de García 204. sin título, $16.3 \times 22.2$ col. Sra. Ma. Luisa Vda. de Garcia 205. sin título, .22 x.22 col. Sra. Ma. Luisa Lazo Vda. de García 206. sin título, $15.5 \times .23$ col. Sra. Ma. Luisa Lazo Vda. de García 207. sin título, .22 x 16.3 col. Sra. Ma. Iuisa Lazo Vda. de García 208. sin título, $.21 \times$ .28 col. Sra. Ma. Luisa Lazo Vda. de García 209. sin título, $19.3 \times 26.6$ col. Sra. Ma. Luisa Lazo Vda. de García 210. sin título, .23 x.30 col. Sra. Ma. Luisa Lazo Vda. de García 211. sin título, $24.5 \times 25.2 \mathrm{col}$. Sra. Ma. Luisa Lazo Vda. de García 212. sin título, $23 \times 31.5 \mathrm{col}$. Sra. Ma. Luisa Lazo Vda. de García 213. sin título, 21.7 x 28.7 col. Sra. Ma. Luisa Lazo Vda. de Garcia.

SAlvador BRU. Exposición presentada por la Galería Pecanins, Hamburgo 103, el 20 de julio.

Datos biográficos del artista: Salvador Bru, nació en Valencia, España, en el año de 1933, actualmente reside en Barcelona. Estudió en la Academia de Bellas Artes de San Carlos de su ciudad. 
HÉctor CRUz. Exposición una nueva visión del paisaje, presentada por la Galería Misrachi, Génova 20, el 8 de julio.

Lo CURSI. Exposición presentada por el Instituto Mexicano Norteamericano de Relaciones Culturales, Galería Nabor Carrillo, Hamburgo 115, el 8 de julio.

Notas sobre lo Cursi. Lo Cursi es lo exquisito fallido. Lo Cursi es "el quiero y no puedo". Es el querer llegar a las cumbres de lo elegante y de lo distinguido y quedarse a la mitad, pero, por supuesto, creyendo haber llegado, pues una de las características esenciales de lo Cursi, de esa falla de lo exquisito, es la sinceridad. Mas lo cursi es toda una actitud vital que es necesario comprender.

Cursi es el ensueño diario de la humanidad que se imagina mejor de lo que es, elevándose por la imaginación de deseadas categorías imposibles de cumplir. El ensuer̃o de la mesera que se imagina casada con el más guapo de los comensales a quien diariamente sirve; el ensueño del chofer de llevar en su automóvil a princesas suculentas; el ensueño del cartero que imagina novelitas cortas con los nombres que le atraen en los sobres; el ensueño del sacerdote de que permanezcan siempre puros los niños a quienes ha dado la primera comunión; el ensueño de las solteronas de que se diga que su intocado cuerpo es más hermoso que el de las madres fecundas; el ensueĩo de todos, viéndose en oníricas representaciones en un estado de bienestar digno de envidia; el "si fuera rey" o "si fuera millonario", todo eso es cursi. Todo sueño despierto es cursi porque es la búsqueda de lo exquisito, de lo bello, de lo grande, inalcanzable. Pero todo sueño es necesario como válvula de escape, como huída fácil, pero profunda y necesaria, de la cotidiana y triste realidad, más llena de espinas que de flores, para decirlo con una frase deliciosamente cursi.

"Si tienes un hueco en tu corazón llénalo de amor", dijo cursi y verdaderamente el verdaderamente cursi Amado Nervo. Yo diria: "Si tienes un hueco en tu corazón, llénalo de cursilería."

Para el cursi la vida es continua sucesión de felices deseos y utópicas realidades. Aśi es que las modas casi no aparecen, los grandes sucesos mundiales carecen de "atractivos", y los modelos y temas siguen siendo parecidos a los años anteriores.

Lo Camp es muchas cosas, tantas, que acaba por perderse en su misma magnitud. Es lo pasado, pero no todo, es lo demodé, pero selecto; es algo de lo barroco y todo el Art-Nouvean, es mucho de lo cursi y casi todo el mal gusto; es lo "tan malo que resulta bueno", es lo charro y lo chabacano; lo pedante y lo pedestre, lo vulgar y... todo lo que pueda ocurrirse a quien se ponga unos anteojos de manufactura y gra $\rightarrow$ duación óptica marca "camp".

\section{Francisco de la Maza}

A propósito de las notas sobre lo Cursi. Lo Cursi no es característico de estas últimas décadas del Siglo xx. Muy común hace medio siglo, hoy, ya avanzado el último tercio del Siglo $\mathrm{xx}$, van quedando pocas cosas y unas cuantas actitudes humanas dignas de esta designación.

Años difíciles los que vivimos han visto desaparecer los tiernos bibelots llenos de flores y de ángeles que alguna vez adornaron salas y comedores que hoy son piezas de coleccionistas o se han refugiado vergonzosos en la intimidad de las alcobas de las personas pasadas de moda $y$ de años. Como buenos cursis se han de asustar 
ante los nuevos atuendos: el cuero de los abrigos y de las faldas mínimas de las señoras, las botas a la federica, los largos cabellos de los señores, los pantalones de campana, los colgajos en el pecho descubierto.

Difícilmente pudieran encontrarse en estos años las características de lo cursi que señala el ilustre historiador y crítico de arte Don Francisco de la Maza. Lo tierno y simple, lo amoroso y dulce han huído de nuestra vida. Un duro cinismo, una conciencia de una realidad cruda los ha substituido. "Ir honestamente vestidos", "ser casto" pertenecen definitivamente a épocas de vida más ingenua. El sentimentalismo que destila lo cursi ha cediclo ante una decidida agresividad, lo diminuto y los diminutivos - que son cursis- han sido vencidos por una relampagueante grandiosidad de las cosas. El blanco, el rosa y el azul - tan cursis- ceden ante el amarillo rabioso $y$ un verde que to es de ninguna esperanza. La búsqueda de lo exquisito ni siquiera se intenta, pues se tiene a mano la materia en bruto tal cual es, y eso es suficiente para calmar cualquier ansia estética; la huída fácil que dan las cosas tiernas es ahora un "viaje" a paraísos mayores. El desconocimiento de "lo indecoroso en el amor" es ahora el conocimiento pleno de los matices y las variantes de esta emoción. Lo moralista ha cedido su lugar a lo amoral y a lo apático.

Producto de la clase media de cualquier país, lo cursi es el rechazo inconsciente de lo popular y lo folklórico; y es el esfuerzo para no caer en un estrato social que a la clase media le parece más bajo o, por lo menos, simbólico de un nivel económico pobre o menesteroso.

Pudiera afirmarse que lo cursi es característico de los pueblos hispánicos o que en ellos lo cursi la tenido señales de virulencia; pero no es así, pues lo cursi aunque con menor frecuencia, fructifica en otros países, como lo demuestran objetos de lejanas procedencias y los vocablos que lo designan. En México escapa a lo cursi la dignidad del indio, pues se lo ha impedido su innato austero sentido de la vida.

Estética de la cursilería. En 1869, el diccionario de la Real Academia Española consigna por vez primera la palabra Cursi, otorgándole la absurda definición de "Que presume de fino sin serlo, ridículo, de mal gusto". De ahí la confusión posterior y las malas interpretaciones que hasta hoy en día se vienen repitiendo.

Resulta obvio el malentendido ya que una cosa es la cursilería y otra muy distinta el mal gusto. Los mancebos epicenos, deliciosos de Gustave Moreau, la filosofía del Boudoir, elegante, de Aubrey Beardsley; las damas noctivagas de Roberto Montenegro, así como las tarjetas postales edípicas del 10 de nayo y las sentimentaloides de San Valentín, las películas silentes de Cleo de Mérode, Pina Menichelli, Theda Bara y del sublime Rodolfo Valentino son hermosas y cursis a la vez, sin enbargo, nunca pueden considerarse de mal gusto, ya que tienen un encanto evocador, nostálgico inefable, que atañe a sentidos y sentimientos ocultos de nuestra vida interior.

Lo cursi comienza con la gran pintura de género de los artistas ingleses, franceses y españoles de los siglos xviı y xix. Los cuadros murales que conmemoraban determinada batalla, así como la reconstrucción histórica-idealizada, por ejemplo, la de los pre-Rafaelitas, caen, por sus formas y su atracción erótica, en los signos de lo cursi, pero jamás concretizan la vulgaridad de lo pueril y lo abyecto.

Como toda posibilidad estética, lo cursi posee niveles o gradaciones: estados en que se inscriben tales manifestaciones. Los grados van desde lo sublime a lo lamentable, de lo inefable al medio tono conmovedor por su ingenuidad. Así, tres sub- 
categorías se palpan en el análisis de la cursilería: la buena o mayor, la regular, y por último la detestable que la colinda con la vulgaridad y también con el mal gusto.

Lo cursi será siempre inquietante, un reto a la osadía analítica y una preferencia en los gustos y las pasiones. ¿Cuán a menudo se escucha de labios de connotados intelectuales expresar su emoción, por ejemplo ante las canciones de Agustín Lara, Raphael o ante la mala pintura y la escultura maternal?

GRUPo ULTRA. Exposición colectiva presentada por la Villa Olimpica, México, del 9 al 22 de julio.

Nombre de los expositores: Susana Carlson, Amalia Franco, Karin Kirchfeld, Eva Laura Moraga, Delfina Vargas.

ERNESTo CARreón. Exposición de pintura "Nadi", presentada por el Instituto Nacional de Bellas Artes, Galerías del Palacio de Bellas Artes, Sala Verde el 9 de julio.

josí maya. Exposición de grabados, presentada por la Galería de Arte. Club para el Desarrollo Humano. Periférico López Mateos 374, casi esquina Alta Vista, el 9 de julio.

Datos biográficos del artista: José Maya nació en México, D. F., en 1941.

TRES ARTistas DE Galicia (JAIME QUESADA, PINTOR; JOSE LUIS DE DIOS, PINTOR; ACISClo MANZANo, ESCULTOR. Exposición presentada por el Instituto Nacional de Bellas Artes, Museo de Arte Moderno, Galería de Exposiciones Temporales, Salas Derecha e Izquierda. Planta Baja, el 11 de julio.

Tres Artistas Gallegos: Jaime Quesada, José Luis de Dios y Acisclo Manzano, nacidos los tres en Galicia e irremediablemente fundidos con la realidad de su tierra por razones étnicas e históricas, testimonian el momento presente en su dimensión intelectual y humana.

Como otros jóvenes artistas de la última generación, asumiendo responsablemente el esfuerzo de los artistas gallegos que los procedieron, están conscientes de que las circunstancias en que vive su país son razones universales que determinan totalmente su trabajo de creación y no desdeñan en absoluto ningún criterio formal siempre que se sustente en un contenido acorde con la realidad en su momento histórico.

Pertenecen a la vanguardia de la neo-figuración europea, exponente de un nuevo realismo que, como todos los movimientos plásticos desde principios de siglo, son el resultado de la pugna entre dos antagonismos clásicos no sólo en arte: idealismo y materialismo, abstracción y realismo.

Declaración: Dentro del idealismo y como muestra de su deshumanización alienante, se pueden citar todas las variantes del movimiento abstracto, entendidos como esteticismo gratuito y privilegiado, sin dar nunca resptuesta ni incidir en la tensión hombre-naturaleza; resultado: arte por el arte, explotación del hombre por el "arte".

Por el contrario, el realismo, liberado ya de todo juego dogmático o raquitismo decadente, considera el trabajo creador como una propuesta humanizadora, dentro de la dialéctica histórica, capaz de ser influido e influir por sí mismo en la realidad social en que se manifiesta.

La búsqueda de "formas" acordes con nuestra realidad compleja y alienante, cuyo 
contenido pretenda la transformación de estas condiciones y que genere nuevas dimensiones de liberación humana, no es una pretensión utópica y gratuita, sino una continuidad en el esfuerzo humano decidido históricamente a transformar la sociedad.

Esta búsqueda se plantea como una desmitificación constante de lo irracional que condiciona el trabajo humano como una alienación y al arte como la "aberración de lo inútil glorificado".

En muchos países esta desmitificación es una realidad común que hermana a todos los artistas comprometidos en la construcción de un hombre nuevo, más racional, y contra la degradación colectiva que imponen la sociedad de consumo, los ghetos culturales, los imperialismos, los inútiles frenos del progreso humano.

La realidad plástica actual en Galicia responde a una ósmosis histórica de aceptación de formas artísticas, no sólo peninsulares, sino europeas y universales, intentando siempre enraizarlas con lo característico diferencial.

Históricamente el romántico y el barroco fueron los estilos que cobraron en Galicia una realidad muy singular y característica, paralela al arte popular. En nuestro siglo y dada la importancia de los movimientos europeos, los artistas de Galicia fueron determinados por los grandes creadores que trabajaban en París, Alemania o Londres, sin apenas sentirse influidos por los artistas y escuelas del resto de España. De esta forma el gran dibujante Castelao coincidió, no solamente en aspectos formales, con Katte Kolwitz; Manuel Colmeiro, profundo conocedor de la escuela de París, incorpora al mundo galaico el espíritu de Cezanne; Goya y Picasso influyen en Laxeiro, como Bonnard y Solana en Arturo Souto.

Nuestros antecesores poseían un contenido auténticamente gallego; sin embargo, la forma pertenecía más bien a la "escuela de París". Nosotros nos sentimos más cercanos en la forma con Holanda que con los países mediterráneos.

Podría hablarse de un concepto de la descomposición de la luz perfectamente atlántico; Van Gogh, Mondrian, el irlandés Bacon, Moore, Munch o Ensor, etcétera, corresponden perfectamente a esta cromática atlántica, donde las “formas" emergen del interior del espíritu, en contraposición a los pueblos mediterráneos en donde es el exterior el que crea un equilibrio interior.

Para nosotros la búsqueda de unas "nuevas formas gallegas" debe fundamentarse en:

1) La destrucción de la perpectiva clásica para adentrarse en espacios creados por la propia mente.

2) La magia del color de otros pueblos nos hace tomar conciencia de nuestros propios valores cromáticos y resucitarlos.

3) La desmitificación de nuestra mitologia no supone la destrucción de la continuidad en los valores mágicos de nuestro pueblo, acordes con el progreso científico.

4) Nuestra propuesta actual es encontrar un equilibrio entre forma y contenido legítimamente gallegos.

Jaime Quesada: pintor. La descomposición de la materia en el constructivismo fue paralela a la deformación del objeto por el expresionismo cubista de "Guernica". En su obra actual, Quesada continúa las tesis características del realismo en su tentativa de demostrar la relatividad de las formas. La destrucción del espacio crea 
un nuevo espacio en los cuadros de Quesada, e incorpora el ser a un mundo aparentemente imaginario porque se plantea al mismo tiempo desde distintos conceptos de la realidad. Las variaciones complementarias en la descomposición del color crean una tensión que paraliza el consciente del espectador para adentrarse furtivamente en su inconsciente.

Quesada descompone el ser humano en toda su degradación y contradicción, buscando de esa manera una nueva ética humanizadora contra la alienación del ser inmerso en las estructuras neocapitalistas.

Nace en Orense en 1937, estudia en la Escuela de Bellas Artes de Madrid y Grabado en París, viaja durante doce años por Europa, Asia, Africa y América.

José Luis de Dios: pintor. Su mundo plástico está decidido por la tensión hombre-naturaleza situados frente a la evidencia de la irracionalidad colectiva. Su obra es, en cierta forma, una racionalización de esta irracionalidad. Hace uso de un simbolismo esperpéntico, a fin de participar en la contradicción impuesta, testimonio de la degradación humana provocada por el inútil cartesianismo occidental.

"Si un artista no dispone de un cerebro libre, no podrá crear absolutamente nada", declara José Luis.

Efectivamente, su código plástico logra la comunicación sin quebrar la libertad emocional del espectador.

Postula en sus obras una ética social que provoca un conflicto con la moral convencional, pero a través de una luz poética, tierna, que nos envuelve y encanta, sin que jamás claudique ante las normas banales de nuestra sociedad de consumo.

Nace en Orense en 1943. Estudió en la Escuela de Arte y Oficios de Orense y Escuela de Bellas Artes de Madrid.

Acisclo Manzano: escultor. Intenta destruir el espacio formal, para adentrarse en nuevos espacios móviles. Esta idea de la dinámica aparente se halla relacionada con la búsqueda de la cuarta dimensión. El análisis del volumen en Manzano es totalmente distinto de los móviles que impulsan a escultores como Moore o Calder. Se trata más bien de concretar formas partiendo de su propio movimiento interior para sintetizar espacios aparentemente estáticos en íntima relación con la dualidad obra-espectador.

Acisclo Manzano es un escultor formal estrechamente emparentado con la neofiguración. Sus hallazgos dinámicos están contenidos en la apariencia abstracta de sus formas, y su escultura es de un concretismo minucioso y perfectamente racional.

Nace en Orense en 1940. Autodidacta. Premio Nacional de Escultura y medalla nacional de Arte Juvenil, Madrid.

Taime Quesada, José Luis de Dios y Acisclo Manzano, pintores los dos primeros y escultor el último, forman una terna de artistas jóvenes gallegos que presentan su obra en México por primera vez.

Con una seria y muy profesional trayectoria artística, son ya bien conocidos en España y en otros países de Europa, habiendo merecido de los críticos, cálidos elogios. Tenemos oportunidad de presentarlos en este Museo, gracias a la ayuda de las autoridades del Instituto Nacional de Bellas Artes, las cuales colaboraron con ellos para hacer posible su permanencia en México y la entrada de sus obras, exponién- 
dolas en esta ocasión en las salas derecha e izquierda de la planta baja de nuestro Museo, seleccionando algunas de ellas.

Seguros de que exhibirlas será motivo de interés en nuestro ambiente artístico, les hemos dado oportunidad a estos tres artistas jóvenes, de recibir nosotros primero, su mensaje de amistad que llevarán por varios países de la América Latina, con sus pinturas y esculturas.

CARMen Barkeda

Cercanos por las fechas de nacimiento y más aún por la tierra donde han nacido, Jaime Quesada, José Luis de Dios y Acisclo Manzano denotan disímiles maneras de concebir el oficio artístico. Pero un rasgo común hermana su trabajo; el placer de multiplicar las formas haciéndolas surgir de un fondo que la angustia suele matizar con insistencia. Sin olvidar la atmósfera exuberante de su provincia, proceden con un impulso que sobrepasa lo anecdótico y señalan, dentro del panorama del arte español del presente, el espíritu intranquilo de una sociedad que no cede a la desesperanza.

En algunas telas de Quesada, la inconformidad se manifiesta en cuerpos humanos cuyo aprobio resume el mundo contra el cual el artista esboza su ademán de protesta. Sin embargo, al lado de esa actitud, no desdeña admitir otras imágenes suspendidas por una gracia en que los más íntimos sentimientos adquieren de pronto estremecido esplendor. Porque para él la pintura debe reaccionar ante la vida y recoger de la sociedad aquello que precipita hacia la indignación o conducta hacia el sosegado contemplar el triunfo de la belleza.

Similar preferencia por los colores luminosos se advierte en José Luis de Dios. Su paleta lo distancia de la pintura -más severa, tendiente al uso de los grises y a los tonos diluidos- que hoy se practica en la Península. Dibujante excepcional, otorga a los hombres y mujeres de sus lienzos un realismo poético sustentado en una vitalidad que testimonia el deseo de conferir, aun a las situaciones más dramáticas, una sensación de humanidad, de compromiso con lo que el acontecer diario nos exige a todos.

No menos dramatismo se trasparenta en las esculturas de Acisclo Manzano. Enemigo del reposo y de la lentitud, imprime a sus creaciones un movimiento al cual sus figuras se acogen armónicamente para desbordarse de sí mismas, impelidas por la inquietud con que las concibió. El barro, la madera, el hierro, los variados elementos a que Manzano recurre para hacer sus piezas adquieren --mediante un evidente afán de procurar la simplificación de las formas- caracteres primitivos que súbitamente son levantados en vilo por la desesperación.

Jaime Quesada, José Luis de Dios y Acisclo Manzano, estos tres artistas de Galicia, se hallan entre nosotros.

\section{Alí Chumacero}

\section{Datos biográficos de los artistas:}

Jaime Quesada, pintor. Nace en Orense en 1937. Estudia en la Escuela de Bellas Artes de Madrid y Grabado en París, viaja durante doce años por Europa, Asia, Africa y América. 
Acisclo Manzano, escultor. 1960. Expone por primera vez en Orense y Vigo, 1961: Viajes por Francia y Alemania con Beca de Estudios.

José Luis de Dios, pintor. Nace en Orense en 1943. Estudios en la Escuela de Artes y Oficios de Orense y Escuela de Bellas Artes de Madrid.

Catálogo: JAIME QUESADA. 1. naturalesa neutra, 1971, óleo $0.95 \times 1.13$ 2. ritual, 1971, óleo, $0.95 \times 1.13$ 3. la tortura, 1968, óleo, $1.65 \times 1.33$ 4. el miedo, 1968 , $1.65 \times 1.33$, óleo 5. emigración 1, 1971, $1.04 \times 0.89$, óleo 6. emigración 2, 1971, $1.24 \times 0.99$, óleo 7 . tecnocracia, $1970,0.68 \times 0.85$, óleo 8 . cibernética, $1970,0.95 \times$ 0.76 , óleo 9. retrato, $1969,0.64 \times 0.88$, óleo 10 odalisca, $1969,0.64 \times 0.84$, óleo 11. pastoral, 1971, $0.76 \times 0.95$, óleo 12. subdesarrollo, $1970,0.94 \times 0.64$ óleo, 13 . guerrillero gallego, $1970,0.95 \times 0.76$, óleo 14 . comunicación, $1970,0.95 \times 0.76$, óleo 15. el baño, 1970, $0.95 \times 0.76$, óleo 16. andiovisual, 1969, $1.43 \times 1.14$, óleo 17. metamorfosis, $1969,1.43 \times 1.14$, óleo 18 . el grito, $1969,1.43 \times 1.14$, óleo 19 . la ley del embudo, $1969,1.43 \times 1.14$, óleo 20. incomunicación, $1970,1.47 \times 1.00$ 21. sonata, 1971, 0.99 × 1.23, óleo 22. camp, 1971, 0.99 × 1.23, óleo 23. España insólita 1970, $1.43 \times 1.14$, óleo 24. Galicia hoy, $1970,3.00 \times 1.80$, óleo ACISCLO MANZANO. 25. Madamita, $30 \mathrm{cms}$. bronce 26. Nai, $20 \mathrm{cms}$. bronce 27 . naturaleza, $30 \mathrm{cms}$. bronce 28. hermanos, terracota, $40 \mathrm{cms}$. 29. descanso, terracota, $30 \mathrm{cms}$. 30. labrego, tetracota, $40 \mathrm{cms}$. 31. campesino, terracota, $25 \mathrm{cnss}$. 32. Anxo, terracota, $20 \mathrm{cms}$. 33. maternidad, bronce $45 \mathrm{cms}$. 34. tríptico, tertacota $30 \mathrm{cms}$. 35 . pensante, madera, $35 \mathrm{cms}$. 36. soldado, madera, $60 \mathrm{cms}$. 37. aullido, terracota $30 \mathrm{cms}$. 38. abade, terracota, $40 \mathrm{cms}$. 39. rapaz, madera, $50 \mathrm{cms}$. 40 . cabeza, terracota, 30 cms. 41. composición, terracota, $25 \mathrm{cms}$. 42. composición, madera, $50 \mathrm{cms}$. 43. composición, bronce, $30 \mathrm{cms}$. 44 . gemelos, madera, 45 cms. JOSE LUIS DE DIOS. Pintor 45. leyenda, 1970, $0.66 \times 0.82$, óleo 46. muy señora mía, 1970, $0.66 \mathrm{x}$ 0.82 , óleo 47 . cocotte en rojo, $1970,0.35 \times 0.47$, óleo 48 cocotte en amarillo, 1970 , $0.35 \times 0.47$, óleo 49. grito, $1971,0.34 \times 0.48$, óleo 50 . silencio, $1971,0.40 \times 0.47$, óleo 51. esperpento, $1971,0.57 \times 0.69$, óleo 52. situación límite, $1970,0.64 \times 0.7853$. el abrazo 1971, $0.57 \times 0.69$, óleo 54. tentsión, 1971, $0.57 \times 0.69$, óleo 55. larga noche de picdra, $1971,0.66 \times 0.81$, óleo 56. recuerdo, $1970,0.82 \times 0.76$, óleo 57. amenaza, $1970,0.81 \times 0.66$, óleo 58. cuarto menguante, $1970,1.00 \times 0.75$, óleo 59 . materialización, 1971, $0.82 \times 0.66$, óleo 60 . poética, $1970,0.72 \times 1.05$, óleo 61 . mimetismo, 1971, $0.66 \times 0.82$, óleo 62. espejismo, $1971,0.66 \times 0.82$, óleo 63. ceremonia de iniciación, 1971, $0.66 \times 0.82$, óleo 64. cuatrocientos o quinientos golpes, $1970,0.66 \mathrm{x}$ 0.82 , óleo 65. enigración, $1970,0.66 \times 0.82$, óleo 66 . hacia la periferia $1970,0.66$ $\mathrm{x} 0.82$, óleo 67. clarividencia, 1970, $0.66 \times 0.82$, óleo 68. darling, 1971, $0.66 \times 0.82$, óleo 69. acoso y derribo, $1970,1.17 \times 0.47$, óleo 70 . bilarcia Hamatobia, 1970 , $0.66 \times 0.82$, óleo 71. arquetipo, $1970,0.66 \times 0.82$, óleo 72. agresión, 1970, $1.00 \times 0.75$, óleo.

el grabado de hoy. Exposición colectiva presentada por la Galería Edvard Munch, Paseo de la Reforma 489, el 12 de julio.

Nombre de los expositores: Gustavo Arias Murueta, Susana Campos, Gerardo Cantu, Juan Manuel de la Rosa, Victor Gochez, Esther González, Jesús Martinez, Francisco Moreno Capdevila, Carlos Nakatani, Carlos Olachea.

ENRIQtue echeverría. Exposición de pinturas, presentada por la Galería de Arte Mexicano, Milán 18 , el 12 de julio.

Catálogo: 1. drusila, $35 \times 25$ cnus. 2. tashana, $40 \times 28 \mathrm{cms}$. 3. Amarile, $40 \times 30 \mathrm{cms}$. 4. Kupa, $55 \times 37$ cms. 5 . Nimra, $40 \times 28 \mathrm{cms}$. 6. Usapa, $40 \times 30 \mathrm{cms}$. 7 . Kitia, $40 \mathrm{x}$ 30 cms. 8. Amarr, $55 \times 37$ cms. 9. Catula, $40 \times 30$ cms. 10. Trasipa, $35 \times 30$ cms. 
11. Haman, 40 × $30 \mathrm{cms}$. 12. Leila, $55 \times 37 \mathrm{cms}$. 13. Sueva, $40 \times 28 \mathrm{cms}$. 14. Magzume, $40 \times 28 \mathrm{cms}$. 15. Naruza, $40 \times 28 \mathrm{cms}$. 16. Bolnia, $40 \times 30 \mathrm{cms}$. 17. Sarupa, $40 \times 28 \mathrm{cms}$. 18. Nahara, $55 \times 37 \mathrm{cms}$. 19. Esmirna, $40 \times 30 \mathrm{cms}$. 20. Hamidem, $40 \times 28 \mathrm{cms}$. 21. Maya, $55 \times 37 \mathrm{cms}$. 22. Euridice, $40 \times 28 \mathrm{cms}$. 23. Zinza, $40 \times 28$ cms. 24. Kupara, $40 \times 30$ cms. 25. Alejandra, $55 \times 37$ cms.

FEDERICo díaz cañeno. Exposición de pintura, grabado y dibujo, presentada por el Departamento del Distrito Federal, Dirección General de Acción Cultural y Social, Galerías de la Ciudad de México, Alameda Central (Sala Hidalgo), del 13 de julio al 7 de agosto.

Datos biográficos: Díaz Cañedo, nació el 25 de marzo de 1935 en Jalapa, Ver.

gustavo montoya. Exposición presentada por la Plástica de México, Londres 139, del 14 de julio al 7 de agosto.

No deja de tener gracia que en los días que registran el empate universal entre el arte figurativo y el abstracto, se le haya ocurrido a Gustavo Montoya trastocar la naturaleza de las cosas convirtiendo en realidad figurativa la abstracción de las piezas de ajedrez.

Toda esta exposición ha surgido de la curiosa idea de lograr excelente pintura mediante múltiples representaciones de la cuádruple batalla originada entre dos jugadores de ajedrez y los treintidós símbolos que éstos emplean para librar silenciosos encuentros intelectuales.

Si alguna vez se ha dudado de la cuantía de originalidad detentada por Montoya, este insólito acto de "pintar ajedrez" demostrará que aquella duda ha sido totalmente infudada; Montoya ha "pintado ajedrez" como puede pintarse paisaje, o figura.

Es decir, ha considerado al endiablado juego como una magnitud enaltecida a la categoría de género pictórico cosa que, hasta donde yo sé, no había sucedido nunca. Lo mismo que una dinastía real, ha quedado aposentada en el trono una nueva familia reinante en el mapa de las especialidades.

En esta exposición ha establecido Montoya dos jerarquías pictórico-filosóficas: el hombre (o los hombres), frente al tablero; y el tablero incrustado en la existencia del hombre (o de los hombres). Causas y efectos interrelacionados.

Comúnmente, en la exposición, el jugador contempla absorto el campo bélico donde se desarrollan las operaciones; mas debemos percatarnos de que no es el jugador a secas, sino el "jugador", o sea el simbólico personaje poseedor de un mecanismo sicológico-cerebral que le permite proyectarse al máximo nivel de la creación estratégica de toda índole, ya sea Napoleón, o Marx o Henry Ford. Es el personaje alucinado defendiendo sus ideas a como dé lugar, aunque respetuoso de las mínimas leyes de convivencia.

Ante el tablero, es una de las dos solas potencias que dirimen su inmediato futuro empleando armas políticas ricas en sutileza e hipocresía: tragedia, ferocidad, obsesión destructiva, egoísmo y, de repente, generosas dosis de humor.

Luego, la contrapartida: la rebelión de las piezas. Estas, un día hartas del nanipuleo de que son objeto, vociferan airadas, alejan al personaje y cobran una súbita independencia; se incrustan — según se dijo- en la existencia y de la conciencia del hombre. $\mathrm{Su}$ abstracción se convierte en imagen de acción directa, que es el instante 
en que el "jugador" se percata de haber perdido la doble partida iniciada; no creyó en el llamado tercer mundo, y ahí lo tiene encrespado, incontenible, en actitud de implacable reproche, o de resuelta agresión. La congoja es mayúscula. El tablero anda a la deriva, sin dirigentes a la vista capaces de componer el barullo que se ha armado.

Cuando juega, Montoya juega al ajedrez; cuando pinta, Montoya pinta como debe hacerlo un artista de su fórmula específica. Conocedor a fondo del juego y de la profesión, puede aunar eficazmente el drama del doble conflicto tangible y subterráneo con una vasta - vastísima- aportación de factores determinantes de que esta estupenda colección del "Ajedrez" transite en un terreno de zozobra que, si es bello en presencia, más acusado resulta ser su valor cuando se patentiza la belleza subjetiva e incomprobable de las ausencias.

Ejemplos de dicha zozobra esas fachadas y situaciones de indole metafísica, angustiosa, donde se materializa $\longrightarrow$ se presiente- una terrible tensión; esas ventanas impertinentemente ocupadas por personajes espectantes e insensibles a la tortura carcelaria y a la matanza, constituyen muestras pictóricas y filosóficas sobre las que nadie había insistido desde los dias en que De Chirico -aposentado en distinta preocupación- descubrió los tremendos organismos emocionales de sus plazas y calles desiertas.

La ausencia de lógica motivación, la presencia de la integral rareza, así como el "normalizar" lo demencial de la revuelta de las piezas -querer ser "jugador" una jieza es tan extraño como ambicionar el hombre ser pieza-, crea un fugaz y positivo desequilibrio mental sólo sanado por la terajéutica de una categoría buena pintura, la que sanó a los estupefactos espectadores de Bosch y de Goya.

Como en el mencionado Bosch, opera en Montoya su especial y misterioso impulso místico, consistente en crear una especie de altares laicos, dorados o plateados, donde veneran ciertas piezas, ubicadas en nichos, a guisa de santos; reinas, alfiles, torres, asoman de sus cubículos poseídos de una súbita y digna unción; sin gesticular ni perorar - la idea es más praxiteliana que berniniana- esparcen esos beatificados la buena nueva de sus oraciones a los oídos sordos de los rebelados, cuya es la mística opuesta: actuar, como violentamente actúa el magnífico centauro antimonárquico que acorrala al rey sobre el convulso tablero, algo así como un San Jorge quien, olvidándose de su enemigo el dragón, la emprendiera contra su amada, la princesa Cleodolinda.

Porque entre mistica y alusión, entre abstracción y figuraciones, ha vinculado Montoya no poco sentido refinado de la paradoja, como el visible estremecimiento eléctrico del cerebro de un jugador, o como las vetustas y polvorientas casacas de que andan tapizados los personajes reveladores del complejo estratégico anteriormente mencionado.

Para la presente exposición ha dado Montoya con la paleta adecuada el imperante tono general de inédita ciencia-ficción que halla en los colores el matemático complemento; realidad e irrealidad cromática barajan espléndidamente sus conveniencias y arbitrariedades, como debe ser cuando un par de caballos adquieren fisiologismo y pelean como lo hacen los caballos de Géricault, o cuando de la frente de un jugador brota un reloj que da horas metafísicas.

Rosas, negros, ocres, grises, contribuyen a redondear lo mágico de esta exposición del "Ajedrez", que debiera gozar de resonancia universal debido al ferviente 
palpitar humano de que blasona, producido este latido en el instante en que ocurren en el mundo cosas por lo menos tan desorbitadas como desorbitado sería que a las piezas del juego las animara de repente algún oscuro dios del pasatiempo.

Estupenda exposición de Montoya; entre imágenes e ideas, legará al recuerdo de todos una concreta sensación de gran pintura, y una vaga sensación de malestar de las que no nos olvidaremos fácilmente.

ENRIQUE F. GUAL

Catálogo: 1. angustia del tiempo, óleo y collage s/fibracel 2. retorno a otra época, óleo $\mathrm{s} /$ tela 3 . collage oro $N^{o} 1$, collage s/triplay 4. collage plata $N^{o} 1$, collage sobre triplay 5. valle de la luna, óleo s/tela 6. collage plata $N^{8} 2$, collage s/triplay 7. gambito de las damas, óleo s/tela 8. evación del tablero, óleo s/tela 9. gambito rojo, óleo y collage s/fibracel 10. estática onirica, óleo s/tela 11. apertura de dos caballos, óleo s/tela 12. terror matemático, óleo y collage s/fibracel 13. collage oro $N^{0} 2$, collage s/triplay 14. conflicto de dos, óleo y collage s/fibracel 15. eclipse negro, óleo s/tela 16. cuadrante antiguo, óleo s/tela 17. sueño premonitor, óleo s/tela 18. autorretrato, óleo s/tela.

Luis Bolland. Exposición de togonurales, presentada por el Departamento del Distrito Federal, Dirección General de Acción Cultural y Social, Galerías de la Ciudad de México, Alameda Central (Sala Juárez) del 14 de julio al 7 de agosto.

Datos biográficos del artista: Luis Bolland, nació en la ciudad de México, D. F.

alicia saloma. Exposición de óleos y acrílicos, presentada por el Departamente del Distrito Federal, Dirección General de Acción Cultural y Social, Galerías de la Ciudad de México en el Centro Social Popular "Aquiles Serdán", Puerto Tampico No 4, esq. Puerto Guaymas, Ampliación de la Col. Casas Alemán, del 15 de julio al 7 de agosto.

ENRIQUe zavala. Exposición de óleos presentada por el Club de Industriales, en el Hotel Camino Real, Mariano Escobedo $N^{\circ} 700$, del 15 al 28 de julio.

Datos biográficos: Enrique Zavala, nació en Jalisco en el año de 1939.

Catálogo: Serie "Hipótesis", óleos s/tela: 1. inventando la realidad, $127 \times 1272$. partitura cromática, $80 \times 150 \quad 3$. infinito botánico, $80 \times 150 \quad 4$. viaje hacia la semilla, $150 \times 150$ 5. mecánica celular, $65 \times 115$ 6. partitura cromática $N^{o} 2,65 \times 115$ 7. eco, $60 \times 75$ 8. navcgante, $50 \times 65$ 9. presencias inmanenles, $150 \times 150$ 10. Eros 433, $127 \times 127$ 11. ser intangible, $70 \times 120 \quad 12$. distinguida mariposa, $127 \times 127$ 13. rcalización, $80 \times 150$ ACRILICO SOBRE TELA 14. germinación inversa $N^{o}$ $1,65 \times 10015$. germinación inversa $N^{o} 2,85 \times 11516$ germinación inversa $N^{o} 3$, $75 \times 90$ 17. germinación inversa $N^{o} 4,150 \times 85$.

holanda. PAís y PUEBlo. Exposición presentada por el Departamento del Distrito Federal, Dirección General de Acción Cultural y Social, Galerías de la Ciudad de México en el Centro Social Popular, Leandro Valle, Av. Sur 8 y Oriente 241, Col. Agrícola Oriental, del 15 de julio al 7 de agosto.

TANGuma. Exposición de óleos, presentada por el Departamento del Distrito Federal, Dirección General de Acción Cultural y Social, Galerias de la Ciudad de Méxi- 
co en el Centro Social Popular, Gral. Ignacio Zaragoza, Av. Oriente 154 y Calle Sur 121, Col. Escuadrón 201, del 16 de julio al 7 de agosto.

gRabado JAPONÉs CONTEMPoráneo. Exposición presentada por el Instituto Nacional de Bellas Artes, Secretaría de Relaciones Exteriores, S. E. P./, Embajada del Japón en México, Sala Internacional del Palacio de Bellas Artes, el 16 de julio.

Daniel machuCA. Exposición blanco y negro de dibujos, presentada por el Departamento del Distrito Federal, Dirección General de Acción Cultural y Social, Galerías de la Ciudad de México en el Centro Social Popular, José Ma. Morelos y Pavón, Lago Trasimeno y Lago Enne, Col. Pensil, del 16 de julio al 7 de agosto.

olGa DonDÉ. Exposición de 14 óleos, presentada por la Galería Arvil, Hamburgo No 241, del 19 de julio al 7 de agosto.

El realisino mágico, la visión íntima, de bolsillo, con que Olga Dondé ingresó profesionalmente en la nueva escuela mexicana de pintura, ha tomado vacaciones. Las frutas de ahora, plátanos y fresas en su mayoría, son resueltas declaraciones de st1 propia identidad. Ya no padecen las trémulas timideces que el espacio imponía, stmiéndolas o relacionándolas. El poyo de una ventana, un boquete hacia el infinito el último escalón de una escalera, la reducción, la humildad, eran los restiltados de esa inserción en el espacio. Ahora no. Ahora son frutas resueltas y desenfadadas que se recortan, con afilado margen, en planas superficies blancas. Al perderse el nexo con un espacio definido, también pierden todo significado extra que no sea el de st1 propia naturaleza. Será la fresa símbolo de todas las fresas o, el plátano, único, primario. Con sus laceraciones y cortes y según la posición en que Olga Dondé las ha apresado, veremos las frutas como tales, o sugiriendo otras formas. Símbolo o realidad, estos ejercicios de la nueva pintora mexicana son ejemplos de probidad, de penetrante aproximación a lo teal, de delicadeza conceptual y, sobre todo, un eslabón nuevo y reluciente de la gran tradición plástica de su país.

José Gómez Sicre, Organización de los Estados A.

EXPOSICIÓN COLECTIVA PERMANENTE (obras donadas por artistas participantes en las exposicones temporales de 1965 a 1971). Presentada por el Museo de las Culturas, Moneda 13, el 19 de julio.

Nombre de los expositores: Guillermo Ceniceros (1965-1968), Ayako Tsuru (1969), Luis I. Aragón (1969), Leticia Arroyo (1970), Shirley Marein (1970), Esther González (1970), Bárbara Brunauer (1970), Carlos Nakatani (1970), Marcela López (1970), Taller Experimental de Diaz de Cossio (1971), Valetta (1971), Pavlatta (1971), Chappie Angulo (1971), Xilonen (1971).

pablo weitz y arturo pastrana. Exposición de dibujo, presentada por el Instituto Cultural Mexicano-Israelí, A. C., Tíber No 12, del 20 de julio al 6 de agosto.

JEAN DAvid. Exposición de óleos, presentada por la Galería de Arte Misrachi, Génova 20 , el 22 de julio. 
Pretender presentar una exposición de pintura, sin ser experto en la materia, es gran atrevimiento. En este caso, se mitiga por tratarse de un pintor de mi país que presenta su obra al público mexicano. La amistad y cariño que existen en nuestros dos pueblos y el hecho que México, gracias a los esfuerzos de su magnífica pléyade de pintores, ha sabido conjugar una tradición que, aunque reciente, tiene una constante específica, con la exploración permanente de nuevas formas de expresión, facilita el empeño.

Israel, nación vieja en un país nuevo, consagrado a la tarea histórica de la reunión de las diásporas judías, ha beneficiado del asentamiento en su suelo de artistas llegados de los cuatro rincones, poseedores de visiones y técnicas distintas. Colocado en el crucero de tres continentes y abierto a todas las expresiones culturales contemporáneas, sus artistas se han incorporado de lleno a las diferentes corrientes del arte que imprimen su sello a nuestra época.

Jean David es exponente de estos elementos que hoy se encuentran en Israel. Su fina sensibilidad y su depurada técnica, lo han consagrado como uno de los maestros de nuestra pintura contemporánea. Esta exposición de su obra más reciente contribuirá, sin duda, a un mejor conocimiento de la pintura israelí en México.

\section{Abraham Daron. Embajador de Israel}

Datos biográficos: Jean David nació en Bucarest, Rumania, en 1908. A temprana edad emigró a París, donde su entrenamiento artístico estuvo a cargo de algunos de los más connotados artistas de la época.

Catálogo: 1. kermesse $I, 116 \times 89 \mathrm{cms}$. 2. kermesse $I I, 116 \times 89 \mathrm{cms}$. 3. los muros, los rostros $I, 100 \times 89 \mathrm{cms}$. 4. dos desnudos, $100 \times 89 \mathrm{cms}$. 5 . kermesse III, $100 \times 89 \mathrm{cms}$. 6. el cazador de mariposas $I, 100 \times 81 \mathrm{cms}$. 7. el cazador de mariposas $I I, 100 \times 81 \mathrm{cms}$. 8. los muros, los rostros $I I, 100 \times 81 \mathrm{cms}$. 9. naturaleza muerta, $100 \times 81 \mathrm{cms}$. 10. la monja, $100 \times 81 \mathrm{cms}$. 11. mujer en amarillo, $92 \times 73 \mathrm{cms}$. 12. niña paloma I, $81 \times 65 \mathrm{cms}$. 13. niña paloma $I I, 92 \times 73 \mathrm{cms}$. 14. desnudo $I, 92 \times 73 \mathrm{cms}$. 15. niña paloma $I I I, 92 \times 73 \mathrm{cms}$. 16 . desnudo $I I$, $73 \times 65 \mathrm{cms}$. 17. marina $I, 73 \times 60 \mathrm{cms}$. 18. marina con pájaros, $65 \times 50 \mathrm{cms}$. 19. peces, $65 \times 50 \mathrm{cms}$. 20. marina II, $65 \times 50 \mathrm{cms}$. 21. doble retrato, $55 \times 50$ cms. 22. niña paloma $I V, 55 \times 46 \mathrm{cms}$. 23. niña paloma $V, 55 \times 46.24$. niña paloma $V I, 55 \times 46 \mathrm{cms}$. 25 . retrato, $46 \times 38 \mathrm{cms}$. 26. doble retrato $I I, 46 \times 38$ cms. 17. dibujos.

LUIS TORREBLANCA. Exposición de esculturas, presentada por la Galería José Ma. Velasco, INBA/S. E. P., Peralvillo 55, del 23 de julio al 21 de agosto.

LUis LEMUs. Exposición de obras recientes, presentada por la Galería José Ma. Velasco, INBA/S. E. P., Peralvillo 55, del 23 de julio al 21 de agosto.

GAY SChAUbERT y J. R. C. MANto. Exposición de obras, presentada por la Galería Edvard Munch, Paseo de la Reforma 489, del 26 de julio al 9 de agosto.

Francisco garcía simona. Exposición de pintura Indigena (NAIF), presentada pot la Galería Central de Arte Moderno, Av. Juárez 4, el 27 de julio. 
Francisco García Simona es un campesino, hijo y nieto de campesinos, que nació y vive en Ameyaltepec, en el Estado de Guerrero. Pasó apenas dos años por la escuela y las letras guardan para él todo el mistero de lo desconocido. Miembro del Ejido "Parcela", en su pueblo, cultiva el maíz y el ajonjolí y está casado en segundas nupcias.

A los 20 años comenzó a pintar, primero en cerámica, en alfarería popular. Después siguió pintando sobre todo aquello que quedó a su alcance y en la actualidad pinta sobre papel de amate.

La pintura de García Simona no es ese arte primitivo que se concentra en la repetición constante de los temas descubiertos originalmente por algún artista ignoto. Francisco García Simona es un artista y no un artesano. Su pintura es rica en imaginación y profundamente creativa. Su obra reúne todas las características de la nejor pintura naif; su riqueza en el colorido, su cuidado en los detalles, su observación de la naturaleza y su desarrollo ingenuo, libre de todo problema de perspectiva, lo sitúan indudablemente en una escuela indigena mexicana que puede muy bien, dentro de las características técnicas del papel de amate, compararse con la obra igualmente naif del aduanero Rousseau o con la más moderna de Moisés Vivanco.

Mientras la inmensa mayoría de los pintores de amate se dedican a la simple decoración, no en todos los casos muy afortunada, Francisco García Simona recoge la vida y la tradición del universo que él conoce y la reproduce, recreándola, en un mundo de color y de expresión, en el que el movimiento ha sido captado magistralmente en líneas llenas de vigor y de vida.

La diferencia esencial es clara: Francisco García Simona es un verdadero artista.

Juan Miguel de Mora

wILliam QUINN. Exposición de serigrafías, presentada por el Instituto Mexicano Norteamericano de Relaciones Culturales, A.C., Galería Nabor Carrillo, Hamburgo 115 , el 29 de julio.

Datos biográficos del artista: William Quinn, nació en St. Louis, Missouri, en 1929. Estudió en la Universidad de Washington, en St. Louis, Mo. de 1949 a 1953.

CHARLES bowdLear. Exposición presentada por el Instituto Mexicano Norteamericano de Relaciones Culturales, A. C., Galería Nabor Carrillo, Hamburgo 115, el 29 de julio.

Datos biográficos del artista: Charles Bowdlear, nativo de Colorado, es graduado de la Universidad del Estado de Michigan y más tarde, obtuvo su doctorado en la Western Reserve University.

JosÉ Hernández delgadillo. Exposición Seres y Hechos, presentada por la Fundación Cultural Miguel Cabrera, García Vigil 818, Oaxaca, Oax., el 23 de julio.

\section{AGOSTO}

pensamiento mágico. Exposición presentada por el Instituto de Arte de México, Puebla 141, el 5 de agosto. 
TRES CARICATURISTAS EN LA PINTURA: Exposición presentada por la Galería Chapultepec, INBA, Insurgentes Sur número 11 bis, el 3 de agosto.

Nombre de los expositores: Leonardo Vadillo, Helio Flores, Eduardo del Rio.

Datos biográficos de los artistas: Vadillo, nació en México, D. F., el año de 1929. Escuela Esmeralda. Flores, nació en Jalapa, Ver, en el año de 1940. Artes Plásticas de la Universidad de Jalapa. Del Río, nació en Zamora, Mich., en el año de 1943.

Cartos cantú. Exposición de dibujos surrealistas, presentada por la Galería Chapultepec, INBA, Insurgentes Sur número 11 bis, el 3 de agosto.

GERTRUDE DUBY Y SU OBRA GRÁFICA. EL HOMBRE, LA ARQUEOLOGÍA Y EL PAISAJE DE chiapas. Fxposición presentada por el Instituto Nacional de Bellas Artes, Sala Internacional, Palacio de Bellas Artes, el 4 de agosto.

RoBert kAUpelis. Exposición de pinturas recientes, presentada por la Galería Arvil, Hamburgo 241, del 9 al 28 de agosto.

TRES PINTORES TABAsqueños. Exposición de acuarelas, óleos y dibujos, presentada por el Instituto Nacional de Bellas Artes, Galerías del Palacio de Bellas Artes, Sala Verde, el 10 de agosto.

Nombre de los expositores: Miguel A. Gómez $V^{\prime}$ entura, Heberto Hernández Triano y Daniel Montuy.

MA. TERESA tORAL. Exposición presentada por el Salón de la Plástica Mexicana, INBA/S. E. P., Havre No 7, del 10 de agosto al 2 de septiembre.

Leonel MAciel. Exposición presentada por el Salón de la Plástica Mexicana, INBA/ S. E. P./, Havre número 7, del 10 al 31 de agosto.

La obra pictórica de Leonel Maciel es más que el acoplamiento de toda suerte de figuras, objetos, animales, máscaras y rostros, la trabazón violenta, la lucha terrible por sobrevivir de un sinnúmero de materiales y, en la mayoría de los casos, la lucha de unos por sobrepasar a otros en la exuberante revolución de colores, formas y texturas que no van más allá, ni son otros sus propósitos, de materializar escenas o simplemente personajes y signos de la vida cotidiana.

Más que en ningún otro momento, hoy el material en la pintura adquiere una importancia extrema. Extremo por supuesto peligroso cuando se trata de conferirle una misión que puede no cumplir muy a pesar de todo el talento invertido en ello. Aun el reciente "Arte Matemático", donde la colección de un material era ya, por sí un rasgo de su carácter, su expresividad dependía por completo de la armónica de sus texturas, composición en el blanco entre el "peso visual" de cada uno de ellos y la repercusión sensacional posible a reproducir.

Pero, en la obra de Maciel, la textura y la apariencia de los materiales funcionan de una distinta forma, forma lograda para la obra en sí, difícil de generalizar o de hacer ejemplo de ella, en poder expresivo, por su presencia saturadora del ámbito visual, elimina prácticamente el acercamiento delicado, la identificación íntima. la satisfacción de una necesidad originada al desear cierta placidez, cierta conjunción sosegada. 
Por principio, la obra de Maciel no puede esperar esto $y$, por tanto, su afán es el de inquietar de la manera más directa, a primera vista (aunque la mirada sea del mismo tipo de la que dirigimos mecánicamente a la calle o a un anuncio), y esa inquietud se puede llamar malestar y no angustia.

Por un lado, la unión violenta de los colores más estridentes, el uso de contrastes extraordinariamente candentes, constituyen el movimiento cromático, la pulsación exasperante que cumple su cometido de inmediato, al priner golpe de vista y, por otro, la intervención de metales, maderas, objetos de uso común, fuertes pincelazos, trazos remarcados hasta la obsesión, con figuras las casi siluetas, los rostros, espacios que en su apretado fluir no permiten la evasión de la mirada.

El afán desmedido de llenar totalinente las áreas llega a los extremos de no permitir un solo milímetro vacío. Saturar el espacio siempre de una distinta manera, con una distinta textura, sobrepasando cualquier sentido de la proporción, logrando la intención de plasmar un instinto salvaje, primitivismo desbocado que, quien sabe hasta qué punto deliberadamente, establece una singular forma de lucubración.

La especie de narración final sobre el acontecer cotidiano equivalente al de una aldea primitiva proyectado hacia nuestra realidad (con la que puede confundirse) es sumamente simple, sintetizaciones a un solo momento, a veces a un retrato, de la interpretación a una manera de vida, figura simbolo para la sociedad de unos cuantos hombres descrita con sonidos análogos a los de una danza, a los de una escenificación elemental de hechos remotos, legendarios aun cuando siguen presentes.

La reiteración no ofrece matices, silenciosos o vacios; toda la obra expuesta de Maciel, está ejecutada bajo una emoción que asimila las formas, los colores, encontrados en medio de una luz terrible, caliente, que abre plenamente a la vista los más llanos sentimientos, sin recodos, sin coyunturas, cada cuadro puede ser el objeto mismo a representar, la construcción del modelo mismo que ahí quedará. No se le invoca, se le crea. Esto tiene particular interés cuando este objeto no es una abstracción, sino la figura clara, desposeída de cualquier hálito humano. Sus formas son, thora si, representadas por un material, por un color o una textura, que nada tiene en común con el original intuible. La forma obedece al material y no a un modelo innaginado o existente.

Se construye un cuerpo, un animal, una máscara, una escena, sobre el cuadro y éste será entendido como tal y no como una visualización.

Es ya integrante de otro mundo donde no se puede lablar de magias sino de brujería.

Sus posibles conexiones con el arte primitivo africano son exigentes en cuanto a la manera de utilizar la materia física y poco en cuanto a creación, invención de formas o de formación. Pero toda identificación o utilización consciente de ciertos recursos está encaminada a encontrar una particular concepción del espacio, de la figuración, en la integración no ya de un mundo espiritual sino uno de objetos, de las cosas que, al contacto con la vida actual dependiente directa de los objétos mecanizados; este primitivismo no totalmente ingenuo llega a ser una lección extravagante, absurda, que se presenta en el momento en que sólo puede producir un choque. 
La incomprensión. Esta es una enérgica, extraña y antibella aparición de figuras y objetos que creiamos haber dejado atrás.

\section{Luis Carlos Emerich}

50 pequeñas obras. Exposición de seis pintores, presentada por la Galería de Arte Plástica de México, Londres 139, el 11 de agosto.

CHIle. Exposiciones de pintura y escultura, de la obra de José Venturelli, Pablo Burchard y Sergio Castillo, presentada por la Embajada de la República de Chile, Instituto Nacional de Bellas Artes, Museo de Arte Moderno, Bosque de Chapultepec, Galería de Exposiciones Temporales, Planta alta, el 12 de agosto.

IRENE ARIAS. Exposición retrospectiva 10 años de dibujo, presentada por el Departamento del Distrito Federal, Dirección General de Acción Cultural y Social, Galerías de la Ciudad de México, Alameda Central, Salas Hidalgo y Juárez, del 13 de agosto al 4 de septiembre.

No era necesario una muestra dibujista de Irene Arias para comprobar el acendrado espíritu formal y poético que caracterizan a su obra. Pero este notable suceso nos permite encontrar un mundo pictórico muy personal, donde la finura del color, el trazo exacto y la composición, sostienen una atmósfera a veces onírica, a veces real, siempre llevada por una mano firme hacia una decantación visual de sus elementos.

Su apego a ciertas figuras naturales que confornan la unidad de sus dibujos, no es propiamente un signo de ingenuidad o dejadez, sino al contrario, es el toque personal que marca la intención temática y plástica de la autora, con los que ella quiere hacernos más placentero y alígero este mundo - su mundo- que nos ha tocado vivir.

Admiramos, repito, el colorido, la sencillez en el trazo, la composición, la figura hunana, los animales, el mar, las "mariposarias", con la seguridad de que nuestra experiencia quedará enriquecida al contacto visual de esta obra extraordinaria de Irene Arias, rigurosamente humana. Digamos como Plutarco: la pintura debe ser una poesía muda. iA contemplarla, pues!

\section{Dronicio MORALes}

yolanda melo y JORGe rodríguez. Exposiciones pictóricas, presentadas por la Galería Ildefonso Aguilar, Hamburgo No 135-E, hotel El Presidente, el 13 de agosto.

Carlos tejeda y la magia de méxico en el paisaje. Exposición presentada por el Instituto Nacional de Bellas Artes, Museo de Arte Moderno, Bosque de Chapultepec, Galería de Exposiciones Temporales, Salas derecha e izquierda, planta baja, del 15 de agosto al $1^{\circ}$ de septiembre.

FRED DE KEIJZER. La última Tentación. Exposición presentada por la Galería Edvard Munch, Paseo de la Reforma 489, del 16 al 30 de agosto. 
holANDA, PAís Y Pueblo. Exposición presentada por el Departamento del Distrito Federal, Dirección General de Acción Cultural y Social, Galerías de la Ciudad de México en el Centro Social Popular "Gral. I'gnacio Zaragoza", Av. Oriente 154 y Calle Sur 121, Col. Escuadrón 201, del 17 de agosto al 4 de septiembre.

ALUmNos del taller dE LA GRÁfica popular. Exposición presentada por el Departamento del Distrito Federal, Dirección General de Acción Cultural y Social, Galerías de la Ciudad de México, en el Centro Social Popular "José Ma. Morelos y Pavón", Lago Trasimeno y Lago Erne, Col. Pensil, del 17 de agosto al 4 de septiembre.

Nombre de los alumnos: Lautaro Barra, Osvaldo Barra, Guillermo Bejarano, Gracicla Día de León, Guillermo Espinoza, Bertha Guerrero, Claudia Hendler, Alejandro Martinez, José Mendarozqueta, Samuel Menache Modeano, Yolanda Muñoz, Martha Ramirez, Elena Vega. Maestros: Jesús Alvarez Amaya, Angel Bracho, Elena Huerta.

GaNdoulf ramírez. Exposición encaústica s/papel, presentada por el Departamento del Distrito Federal, Dirección General de Acción Cultural y Social, Galerías de la Ciudad de México en el Centro Social Popular "Leandro Valle", Av. Sur 8 y Oriente 241, Col. Agrícola Oriental, del 18 de agosto al 4 de septiembre.

Por primera vez y con el afán de impulsar a los nuevos valores de la plástica de México, las autoridades del Departamento del Distrito Federal Federal a través de la Dirección General de Acción Cultural y Social presentan la obra de José Manuel Ramírez Gandoulf.

Oriundo de México, Distrito Federal, Ramírez Gandoulf, estudió en la escuela de La Esmeralda; ha participado en dos exposiciones colectivas; una en la Galería Misrachi de esta ciudad y en la Casa del Sol en Acapulco, Gro.

La Dirección General de Acción Cultural y Social se honra en presentarlo en el Centro Social Popular "Leandro Valle".

YolANDA SAvíN. Exposición de obras, presentada por el Departamento del Distrito Federal, Dirección General de Acción Cultural y Social, Galerías de la Ciudad de México en el Centro Social Popular “Aquiles Serdán”, Puerto Tampico número 4 esquina Puerto Guaymas, ampliación de la Col. Casas Alemán, del 18 de agosto al 4 de septiembre.

Como un arte visceral, repleto de intención y de sentido de acomodación en la magnitud de la pintura abierta, Yolanda Savín maneja una gran cantidad de tonalidades indivisibles que fatalmente, con predestinación barroca, saturan de plenitud la práctica ilimitación de sus ideas, que podrían extenderse más y más hasta satisfacer la voracidad de lienzos enormes. Veamos en ello el clarísimo síntoma del tipo de pintura que cultiva, que es el de la infinita prolongación mágicamente limitada por la lógica visual y la sensible. Un vital fragmento de Rubens, ofrece igual resultado.

Indicase así el formidable suceso de unidad planteado por esta poderosa obra de apasionante proyección que semeja luchar contra las leyes de gravedad y surcar los espacios en tanto que logra caracterizarse experimentando las convulsiones de su única teologia. Torturada y vertebrada a la vez, es ésta una pintura con hallazgo de riqueza abstracta. 
Sólido muy sólido el concepto compositivo, aliase con empastes cromáticos correspondientes a la dinámica intensidad de esos cuadros cusya astronómica belleza nos llena de estupor.

$$
\text { Enrique F. Gual, Director del Museo de San Carlos. }
$$

TALLER DE GRABADO INFANTIL. PROF. SHINZABURo TAKEDA. Exposición presentada por el Museo de las Culturas, INAH/S.E.P., Moneda 13, el 21 de agosto.

EXPOSición del círculo de estudios antropológicos. Presentada por el Museo de las Culturas, INAH/S.E.P.., Moneda 13, el 21 de agosto.

emma limón. Exposición de pintura presentada por la Galería Rosano, Florencia 32, del 21 de agosto al 14 de septiembre.

Emilio oRTIz. Exposición de 15 obras recientes, al óleo, presentada por la Galería de Arte Mexicano, Milán 18, del 23 de agosto al 18 de septiombre.

Catálogo: 1. fuga $N^{\circ} 1$ 2. fuga $N^{\circ} 2$ 3. árbol azul 4. árbol olimpico 5. interior gris 6. interior con paloma 7. interior verde 8. los gemelos 9. interior azul 10. interior con jirafa 11. árbol solar 12. interior con jirafas gemelas 13. animal mecánico 14. peacock tree 15. indian tree.

JoSEPH NADEL. Exposición de óleos, presentada por el Centro Deportivo Israelita, Galerías C. D. I., Av. Manuel Avila Camacho $\mathrm{N}^{9} 620$, del 24 de agosto al 13 de septiembre.

Datos biográficos del artista: Joseph Nadel, nació en Kovno, Lituania en 1919; al igual que Marc Chagall, su amigo de quien pueden hallársele reminiscencias de fervores y de fe.

Estudió pintura en la Escuela de Bellas Artes de Kovno, Lituania; en el Instituto de Bellas Artes de Tel-Aviv Israel; en la Ecole National Superieur dis Beaux Arts en París y trabajó en mosaico durante varios años con Severine en París.

Es hijo de un rabino, sus estudios estuvieron influidos por la Cábala, filosofía metafísica de los judíos.

La Cábala ha influido su obra pictórica, incluso su composición es, de influencia cabalística. Según el misticismo expresado en La Cábala, el universo se divide en diez esferas: Corona, Sabiduría, Inteligencia, Amor, Poder, Belleza, Eternidad, Majestad y Cimiento.

Nadel expresa en sus cuadros esos temas del misticismo de la Cábala. Para el artista, Safed, ciudad de Galilea, es un diálogo entre los santos, los sabios, las montañas y los valles; Terusalén se le aparece como un diálogo entre los profetas $\mathrm{y}$ las rocas.

WALTER SORGE. Exposición de acuarela y esmalte, presentada por el Instituto Mexicano Norteamericano de Relaciones Culturales, Galería Nabor Carrillo, Hamburgo 115, cl 26 de agosto. 
En el circo del mundo del arte hay todavía muchos de nosotros que rehúsan recorrer la legua, Walter Sorge es uno de nuestros hombres. No pertenece a ningún grupo, no ha lanzado ningún manifiesto; no comparte ningún ambiente común $\mathrm{y}$ aun nuestra comunicación es más sentida que razonada.

A pesar de los furiosos cambios en las temporadas de la moda, hay hombres singulares y serenos que día tras día se enfrentan a la fragilidad de la belleza. De igual manera que la tierra llana y exigente de su nacimiento, Walter Sorge enmarca sus imágenes con valor, directamente y sin compromisos.

Su sensibilidad hacia el hombre y sus propósitos saturan su ser y su obra.

Sería imposible para él ver la vida en otros términos. Su vida y su obra están llenas de promesas y su búsqueda para lograr una visión personal ha de continuar sin importar el precio.

En sus obras, Sorge nos da sus visiones con honradez y sensibilidad y solamente nos pide que hagamos el mismo esfuerzo en nuestra propia manera.

JohN PAUL JoNis

Datos biográficos del artista: Walter Sorge, nació en Forestburg Alta Canadá, en 1931 .

zUKor. ENRIQUE z'́ñIgA coRDero. Exposición presentada por la Financiera Comermex, S. A., Uruguay 66, el 27 de agosto.

Datos biográficos del artista: Enrique Zúñiga Cordero nació en la ciudad de Puebla, tiene 34 años y viene de una familia de pintores.

ACUARELa 71. Exposición presentada por la Galería José Ma. Velasco, INBA/S. E. P., Peralvillo 55, del 27 de agosto al 19 de septiembre.

Nombre de los expositores: Martha Orozco, Luis Toledo, Van Kurczyn, Angel Mauro.

exposición de trabajos Del $2^{\circ}$ ciclo de talleres sabatinos 1971. Presentada en gobelinos, cerámica, esmaltes por el Museo de las Culturas, INAH/S.E.P., Moneda 13 , el 28 de agosto.

Nombre de las expositoras: Profesora Marcela López, profesora Irma Peralta de Núñez, profesor Pablo Cervantes Laguna.

martín Battersby. Exposición presentada por la Galería Arvil, Hamburgo 241, del 30 de agosto al 18 de septiembre.

elva garma. Exposición de collages, presentada por la Galería Chapultepec, INBA, Insurgentes Sur No 11 bis, el 31 de agosto.

Datos biográficos de la artista: Elva Garma, nació el 10 de enero de 1943, en México, D. F., estudió arte en la Escuela Nacional de Pintura y Escultura La Esmeralda, en 1964-1968.

amalia franco. Exposición de escultura, presentada por la Galería Chaputepec, Av. Insurgentes Sur No 11 bis, el 31 de agosto. 
JUAN CASTAÑEda. Exposición de metales, presentada por la Galería Chapultepec, INBA, Insurgentes Sur No 11 bis, el 31 de agosto.

Datos biográficos del artista: Juan Castañeda nació el 20 de septiembre de 1942, en Aguascalientes, Ags. Estudió arte en el Instituto Aguascalentense de Bellas Artes durante los años de 1962-1963. Escuela Nacional de Pintura y Escultura La Esmeralda durante los años de 1964-1968.

ENRIQUe zavala. Exposición de 12 óleos recientes, presentada por la Galería de Arte Mexicano-Florencia, Florencia 35-E, el 31 de agosto.

LEONEI GÓNGORA. Exposición obra gráfica y transformaciones, presentada por la Galería Pecanins, Hamburgo 103, el 31 de agosto.

ARNOLd BELKIN. Exposición figuración estructurada 1970-71, presentada por la Galería Pecanins, Hamburgo 103, el 31 de agosto.

1 x 3. Exposición presentada por la Galería Juan Martín, Amberes 17, del 31 de agosto al 20 de septiembre.

Nombre de los expositores: Octavio Paz (poesía), Adja Yunkers (pintura), Rodolfo Krasno y Vicente Rojo (escultura).

Las obras que figuran en esta exposición son el fruto de la colaboración entre un poeta y tres artistas. Un experimento común pero realizado independientemente por tres creadores en tres ciudades: Adja Yunkers en Nueva York, Rodolfo Krasno en París y Vicente Rojo en México. Las obras expuestas no son ilustraciones de los textos de Octavio Paz: son objetos plásticos y verbales (también sonoros en el caso de la música de Edgardo Cantón para el libro objeto) dueños de vida propia. No poesía pintada ni pintura poética sino objetos sensibles y mentales en los cuales los signos plásticos y los signos poéticos sostienen un diálogo.

Datos biográficos: Adja Yunkers, nace en Riga, Letonia en 1900. Estudia en la Escuela de Arte de Leningrado en 1914.

ADRIÁN BRUN Y LIBORIO L. NAVARRETE. Exposiciones presentadas por la Fundación Cultural Miguel Cabrera, Calle de García Vigil 818, Oaxaca, Oax., el 14 de agosto.

\section{SEPTIEMBRE}

exposictón colectiva. Presentada por la Galería de Arte Gandhi, Taxqueña 128, el 2 de septiembre.

Nombre de los expositores: Humberto Aceves, Tina Ballester, Martha Cánovas, Fernando Diaz de la Serna, Iliana Fuenter, Vicente Gandía, Rosa B. de Gaos, Claudia Hendler, Carmen Mones, Bujáidar.

FERNANDO vilchis. Exposición de grabados en metal, presentada por la Galería Plástica de México, Londres 139, del 3 al 25 de septiembre. 
Catálogo: 1. elefante azul 2. unicornio 3. paisaje como balanza 4. chivo 5. salta pa-trás 6. dragón verde 7. árbol $N^{0} 5$ 8. toros 9. Aplysia Punctata 10. cerasa babalus 11. la ventana 12. señal $N^{Q} 1$ 13. señal $N^{o} 214$. señal $N^{Q} 315$. señal $N^{P} 4$ 16. señal $N^{P} 5$ 17. señal $N^{0} 6$ 18. señal $N^{0} 7$ 19. señal $N^{P} 8$ 20. señal $N^{0} 921$. señal $N^{0} 10$ 22. ventanas 23. señal $N^{\varphi} 11$ 24. paisaje con flor 25. toros (1/1) 26. paisaje $N^{P} 1$ 27. paisaje $N^{Q} 2$ 28. paisaje $N^{P} 3$ 29. paisaje

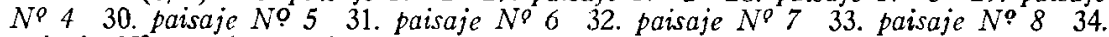
paisaje $N^{\circ} 935$. paisaje $N^{\circ} 10$.

MaNuel muñoz olivarez. (25 años de pintura), exposición presentada por el Departamento del Distrito Federal, Dirección General de Acción Cultural y Social, Galerías de la Ciudad de México, Alameda Central, Salas Juárez e Hidalgo, del 4 al 29 de septiembre.

Varias razones enriquecen el agrado con que me honro en presentar la exposición que de la obra plástica de Manuel Muñoz Olivares, realizan las acreditadas Galerías de la Ciudad de México.

En primer lugar, porque él y yo somos coterráneos en la medida en que yo "nací a las letras" en la misma Coahuila en que él -muchos años después- abrió los ojos a la belleza y dispuso sus manos a solazarse en recrearla sobre lienzo o papel.

En segundo y muy principal, porque corridos los años, desde su juventud cuando absorbió las enseñanzas del retratista Manuel Guillermo Lourdes, colaboró en la Opinión con retratos y cartones sociales y vino a la ciudad de México a proseguir sus estudios de pintura y dibujo.

En 1962 expuso sus obras en Ciudad Juárez, El Paso Texas, Santa Fe y Alburquerque y volvió a esta ciudad de México para recibir el espaldarazo artístico de la propia capital.

En 1963 triunfó en el concurso convocado para hacer el retrato al óleo de la maestra Eva Sámano de López Mateos. Desde 64 dio clases de Artes Plásticas en el INBA y es miembro del Departamento de Restauración de Obras en Arte, al mismo tiempo que imparte clases de Artes P'lásticas en la Escuela Secundaria del Distrito. En 67 pintó un óleo del Presidente Kennedy para el museo que en su memoria se construye en Boston, Mass. Pero sin duda, la experiencia más importante para su oficio de pintor fue la que le proporcionaron sus viajes a Génova, Venecia, Florencia, Pisa, Asís, Siena, Roma, Nápoles, Pompeya, Herculano, Amalfi, Sorrento, Capri, Barcelona, Madrid, Sevilla, Córdoba y Lisboa; sitios hermosos, de los cuales él trasladó al lienzo la imagen de la manera admirable como había logrado ya perfeccionar su arte de pintor y acuarelista.

Por todo ello, pero sobre todo por lo que verán los concurrentes a su exposición, a un pintor que no oculta su ineptitud bajo disfraces de modernidad, sino que siguiendo el ejemplo de los artistas valiosos de todos los tiempos; primero domina su academia y su clasicismo y después crea. Manuel Muñoz Olivares ocupa un lugar de primera fila en la pintura mexicana de tolos los tiempos.

SALVADOR NOVO

ERIC RENNER. Exposición de fotografías Ticul-Yucatán, presentada por el Instituto Nacional de Bellas Artes, Departamento de Artes Plásticas, Museo de Arte Moder- 
no, Bosque de Chapuitepec, Galería de Exposiciones Temporales, planta baja sala izquierda, el 5 de septiembre.

ESTANISLaO Contreras. Iixposición de repujados 1970-1971, presentada por el Instituto Nacional de Bellas Artes, Depto. de Artes Plásticas, Museo de Arte Moderno, Bosque de Chapultepec, Galería de Exposiciones Temporales sala derecha, el 5 de septienbre.

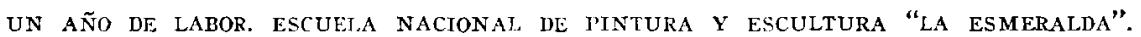
Presentada por el Instituto Nacional de Bellas Artes, Departamento de Artes Plásticas, Palacio de Bellas Artes, sala 1, 2, 4 y 5, el 7 de septiembre.

La libertad de la inteligencia no se circunscribe a recinto alguno. Está garantizada y se pronueve, espontáneamente, en todos los ámbitos de la vida nacional.

En México no laty arte oficial. La creación intelectual no es objeto de consignas estatales ni de compulsión económica. A nadie se persigue, ni siquiera se molesta, por el libre o público ejercicio del pensamiento filosófico, científico, político o econónico.

El país habrá de precisar su camino y su perfil histórico por el talento creador de los mexicanos. La renovación de la sociedad exige un renacimiento de la cultura; demanda auténtico desinterés, rigor en el peusamiento, conciencia crítica y autocrítica, lealtad en la convicción y, sobre todo voluntad de afirmar, en lo más profundo, el vigor del espíritu y la soberanía de la patria.

\section{I.uis Echeverría Álvarez}

E1 resultado final que se obtiene del conocimiento en el terreno de la expresión artística es que existen las más insospechadas posibilidades y resulta concluyente estar contra todo academismo de ayer y de hoy. Todo ello hace necesario establecer con claridad en el estudiante, que la primera condición para ser artista es seguir el propio camino, no seguir pasos ajenos que lo conduzcan a lugares trillados, ya que los conocimientos, la información y el estímulo de las facultades creativas logradas en la Escuela Nacional de Pintura y Escultura son únicamente medios, que él en razón directa de sus aptitudes y capacidad de trabajo llevará a su fin, que es la obra, su obra que es su aventura en la que él es el único protagonista.

Esta exposición de los trabajos de pintura, dibujo, grabado y escultura realizados por los estudiantes en un lapso ordinario de un año de labor tiene por objeto mostrar los resultados obtenidos conforme al plan de estudios, que ha estado vigente desde lace varios años en su planteamiento general; pero renovado y depurado constantemente en sus aspectos metodológicos.

E1 considerable volumen de la obra realizada en el curso 1970-1971 (diez meses de trabajo) obligó a limitar el número de obras debido al espacio de que se disponía para esta exposición. En ella están incluidos trabajos de casi todos los estudiantes de los cursos diurnos del primero al quinto año, ambos cursos están programados en cinco años de estudio. De haber presentado únicamente los mejores trabajos de algunos estudiantes, el propósito de esta exposición se hubiera desvirtuado, ya 
que el principal objetivo es someter esta labor a la reflexión, al análisis y a la crítica con el propósito de superarla sustancialmente.

Así, junto a los trabajos orientados a desarrollar las facultades creativas, se muestran los estndios directos del natural; otros tienen un carácter de libre interpretación formal y los hay también que fueron determinados por un problema preciso a solucionar. En todos ellos se encuentran las primicias de características muy personales, que conducirán sin duda a una sólida formación artística de sus autores. Conviene señalar que muchas de las obras tienen ya una calidad digna de un profesional y que el criterio aplicado en la enseñanza ha dejado fuera la intervención directa del maestro en los trabajos de los estudiantes.

Es sabido que, estudiantes con 10 años o más de permanencia en una Escuela o. taller particular, llegan a realizar trabajos casi de carácter profesional. En esta exposición figuran estudiantes que solamente tienen cinco años de estudio.

\section{Fernando Castro Pacheco}

anatoli Kaplan. Exposición de litografía, presentada por el Instituto Cultural Mexicano Israelí, A. C., Tíber $\mathrm{N}^{0} 12$, el 7 de septiembre.

tanguma. Exposición de óleos presentada por el Departamento del Distrito Federal, Dirección General de Acción Cultural y Social, Galerías de la Ciudad de México en el Centro Social Popular "Leandro Valle", Av. Sur 8 y Oriente 241, Col. Agrícola Oriental, del 7 al 29 de septiembre.

LA PATRia colectiva, taller de Gráfica popular. Exposición presentada por el Departamento del Distrito Federal, Dirección General de Acción Cultural y Social, Galerías de la Ciudad de México en el Centro Social Popular "José María Morelos y Pavón", Lago Trasimeno y Lago Erne, Col. Pensil, del 7 al 29 de septiembre.

EDGardo Coghlan. Exposición de óleos, presentada por la Galería Rosano, Florencia 32 , del 7 al 17 de septiembre.

Alguna vez conversando con Edgardo Coghlan, le pregunté por qué no pintaba más a menudo al óleo. Entonces me contestó que eso le gustaría mucho, pero que por su obra era más conocido en el ambiente artístico como "acuarelista".

En esa ocasión surgió la idea de hacer una exposición para presentar los óleos de Edgardo Coghlan.

Durante más de seis meses Edgardo Coghlan ha hecho una pausa en su mundo. de la acuarela, ha cambiado el agua por el aceite y el papel por la tela, y ha estado pintando lo que ha querido, sin temas precisos o escogidos previamente, sin sugerencias ajenas por determinados lugares o rincones de México.

Cuando platicamos del proyecto le dije que se sintiera con la libertad absoluta de crear lo que su inspiración le insinuara y que pintara sin prisa, tranquilo. Que tratara de tener una paz interior libre de toda presión externa y sintiera esa placentera serenidad qué sólo es realidad cuando los sentidos y el alma se encuentran dentro de la naturaleza humana y silenciosa, casi misteriosamente logran una plena comunión.

Edgardo Coghlan ha vagado por muchos rincones de nuestro hermoso país, lo 
mismo en el mar que en la montaña, por los pueblos y por la ancha campiña mexicana. Con amor, serena y tranquilamente, con esa sencillez del hombre simple, ha logrado que sus pinceles plasmen en el lienzo diversas y distintas expresiones espontáneas de su sensibilidad y de su arte de pintor tan singular.

Edgardo Coghlan dijo alguna vez "No creo que el artista deba aislarse en un 'autismo' y hacer de su obra un jeroglífico. Prefiero el ejemplo de los grandes maestros que siempre usaron un lenguaje directo y comprensible."

Por eso, en estos óleos, Edgardo Coghlan pintó lo que vieron sus ojos y su alma.

Arturo Alonso

Catálogo: 1. paso de Huitzila 2. desde los Oteros 3. atardecer 4. el caminante (acuarela) 5. el atrio 6. laguna de Jonacatepec 7. paisaje lluvioso 8. camino de Totolapan 9. la hacienda (acuarela) 10. Tlalmanalco (acuarela) 11. patio poblano (acuarela) 12. la mube (acuarela) 13. vereda solitaria 14. amanecer en el puerto 15. botes camaroneros 16. el estero azul 17. lago de Pátzcuaro (1) 18. marina (1) 19. la carreta (acuarela) 20. calle de Pátzcuaro 21. desde el Iztaccíhuatl 22. cerros de Tepostlán 23. Zenantla 24. recogiendo rastrojo 25 . el polvo del camino 26. valle de Tasquillo 27. las Hayas de Aculco 28. en el mercado 29. garambullos 30. al pie de la Cuesta 31. la sacristía 32. templo de la Conchito 33. el descanso 34. jalando la red 35. el regreso 36. tianguis blanco 37. Cuetzalan 38. el vado 39. ganado 40. el Ventorrillo 41. paisaje de Anáhuac 42. camino con cazahuates 43. laguna plateada 44. playa de las gaviotas 45. Manzarillo 46. marina (2) 47. Popocatépetl 48. la capilla y el paso 49. mubes en la costá 50. lago de Pátzcuaro (2) 51. valle de Bravo 52. el viejo 53. Amanalco 54. barrio de pescadores 55 . paisaje con nubes.

maría elena massap. Exposición de pinturas y dibujos, presentada por el Departamento del Distrito Federal, Dirección General de Acción Cultural y Social, Galerías de la Ciudad de México en el Centro Social Popular "Aquiles Serdán", Puerto Tampico Núm. 4, esq. Puerto Guaymas, ampliación de la colonia Casas Alemán, del 8 al 29 de septiembre.

Su tema principal, casi el único, es el hombre. Tan pronto reflejado en su existencia angustiada en que el dolor y el desamparo le hacen víctima, tan pronto en la serie que retrata al ser humano, célula de una colmena y al mismo tiempo un pequeño cosmos repleto de ilusiones, hallazgos y actos de tanta importancia $y$ trascendencia, a veces, como la influencia de un astro en el mundo. Grupos, rostros aislados que asoman sus rasgos en la ventana del espacio plástico. El hombre actor, el hombre testigo, el hombre que piensa y que acciona; que denuncia, que ataca, que descubre, que se asocia al destino de los otros.

Las formas con que se expresa María Elena son enteramente interpretativas. Los trazos tienen gran vigor y justeza. Aplica con acierto el contrapunto de blancos y negros consiguiendo con ello efectos de mucho dramatismo.

María Elena transita por tal camino, y lo que más sorprende es que no se haya encandilado con ese "teutonismo" feísta que aflige a algunos de los pintores y dibujantes muestros, que militan en el expresionismo. Está en un justo medio, pues ninguna de sus figuras $y$ escenas puede ser tachada de preciosista.

\section{T. Crespo de la Serna}


JORGe edGardo Ramírez. Exposición (obra nueva) presentada por el Departamento del Distrito Federal, Dirección General de Acción Cultural y Social, Galerías de la Ciudad de México en el Centro Social Popular "Gral. Ignacio Zaragoza", Av. Oriente 154 y Calle Sur 121, Col. Escuadrón 201, del 9 al 29 de septiembre.

óscar meraldi. Exposición obras constructivistas (1968-1971), presentada por el Instituto Nacional de Bellas Artes, Depto. de Artes Plástica, Sala Internacional, Palacio de Bellas Artes, el 9 de septiembre.

SAlón DE PIntura 1971. Exposición presentada por el Salón de la Plástica Mexicana, INBA, Havre $N^{\circ} 7$, el 13 de septiembre.

GRUPO ESPIRAL. Exposición colectiva de obras recientes, presentada por el Comité del Centro Deportivo l'sraelita, Galerías C. D. I., Av. Manuel Avila Camacho No 620, el 14 de septiembre.

Nombre de los expositores: Barrios, Camps Ribcra, Casas Castaños, De las Casas, López Soriano, Muñoz López, Nierman, Pérez Barrios, Sabattini, Sisto.

SEREs y Hechos. Exposición presentada por la Galería Edvard Munch, Paseo de la Reforma 489, del 20 de septiembre al 4 de octubre.

Nombre de los expositores: Delgadillo, Ayala y Molina.

Exposición de pinturas y esculturas, presentada por la Galería Arvil, Hamburgo $241,2^{\circ}$ piso, el 20 de septiembre.

Nombre de los expositores: Armando Villagrán, Feliciano Béjar (esculturas), Heriberto Juárez (esculturas) y Francisco Toledo.

Décima exposición del artista, del pintor que supo hacer la disyunción y conjunción entre poesía y explosión cosmogónica del décimo sol. Obra que se abre y se cierra -corolas devotas, seres microscópicos en país de Liliput- como en juego de naipes encantados por el as de corazones: milagros rescatados de la fantasía e imágenes de la imaginación fantasmagórica. Esto es Armando Villagrán y sus metafísicas acepciones fosforescentes y arborescentes. En la cifra cabalística, en el número decimal, en los misteriosos encuentros con el azar, el pintor estuvo y está atento a las posibilidades de inventar, de recrear el mundo real y el de la ilusión --ya de suyo supersticioso y de extraño color- y ha ido canalizando y cimentando, desde el principio, edificio plástico de primer orden que lo coloca, si no a la cabeza, si en lugar destacado y envidiable del arte mexicano de hoy que será muy pronto del ayer.

Armándo Villagrán no necesitó jamás de ninguna "revelación vanguardista" para ser quien fue $\mathrm{y}$ es: parábola de sensaciones $\mathrm{y}$ recuerdos, formas que recuerdan la cotidiana ciudad y la selva presentida con sus transformaciones trascendentes. Las formas de Villagrán las depuró el tiempo de la historia por su "ingenio constructor": inteligencia reflejada en apoteosis gloriosa, en confabulados sueños y en ensueños fabulados de seres y objetos: kai-kus plásticos y mensajes teleféricos.

Su décima muestra es décimo canto y nocturno silencioso. A un poema se responde con otro poema; como ministro se le reflexiona con lóbrega tristeza. Armando Villagrán es ya pintor maduro. Las obras actuales poseen el sello definitivo, el estanclarte, el huracán y las olas del cclaje emocionante y congelado: caleidosco- 
pio y feria, cohetería y laberinto: encuentro con lo "otro" y lo antaño. No me equivoco cuando afirmo que Armando Villagrán es uno de los diez mejores pintores de México. $Y$ un país que tiene diez pintores puede darse por satisfecho.

Alfonso de Neuvillate

PRIMER SALÓN MEXICANo DEL DISEÑo. Exposición presentada por el Instituto $\mathrm{Na}$ cional de Bellas Artes, Depto. de Arquitectura, Museo de Arte Moderno (bosque de Chapultepec), del 21 de septiembre al 17 de octubre.

BoANERges mideros. Exposición de metales, tapices y pinturas, presentada por el Instituto Nacional de Bellas Artes, Depto. de Artes Plásticas, Embajada del Ecuador, Palacio de Bellas Artes, Sala Verde el 21 de septiembre.

Testimonio, color y forma de una dimensión equinoccial.

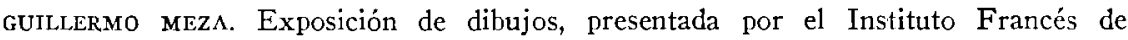
América Latina, Nazas 43, del 22 de septiembre al 4 de octubre.

Esta exposición se presentó bajo el tema "Las Penas de Amor" y 10 diseños para el Ballet K. P. M. de Rossana Filomarino.

25 Niños. Exposición de pinturas, presentada por el Instituto Mexicano Norteamericano de Relaciones Culturales, A.C., Galería Nuevos Valores, Hamburgo 115, el 22 de septiembre.

Nombre de los niños expositores: Alberto León, Sandy Eck, Dobby Eck, Judy Tlach, Donna Roane, Zelinda Rosellini, Lisa Rosellini, John Adams, Mard Tragarz, Carla León, Karen van Maurs. Andrés Roemer, Peggy Snider, Lois Schoenbals, Vivian Treytry, Julia Irvin, Mary Bronson, Ma. de los Angeles Gómez, Débora Sol Chisikousky, Peggy Snider, Neida Joseph.

JOSÉ LUIS NEYRA. Exposición de fotografías, presentada por la Escuela Nacional de Artes Plásticas, UNAM, Sala de Exposiciones, Academia 22, el 22 de septiembre.

exposición colectiva. XX Aniversario de la Galería José Ma. Velasco. Presentada por el Instituto Nacional de Bellas Artes, Depto. de Artes Plásticas, Peralvillo 55, el 24 de septiembre.

roberto montenegro. las manos del mexicano. Exposición presentada por el Museo Nacional de Antropología, el Consejo Nacional de Turismo y el Lab. Museográfico, Sala Temporal, Paseo de la Reforma y Calzada Gandhi, el 24 de septiembre.

JUAN bUÑuel. Exposición presentada por la Galería Pecanins, Hamburgo 103, el 28 de septiembre.

FRANCISCo valero. Exposición integral la pintura frente al funcionalismo arquitec- 
tónico, presentada por Modulock, S. A., sala de exhibición ubicada en Berlín 30, Col. Juárez, el 29 de septiembre.

esteban soto villafaña. Exposición de óleos, presentada por la Galería Chapultepec, Insurgentes Sur número 11, bis (INBA) el 29 de septiembre.

Datos biográficos del artista: Esteban Soto Villafaña, nació en Tampico, Tamps.

Miguel áNGel bRenes. Exposición de esculturas, presentada por la Galería Chapultepec, Insurgentes Sur No 11 bis (INBA) el 29 de septiembre.

FIDEL CORPUS Nava. Exposición de acrílicos, presentada por la Galería Chapultepec, INBA, Insurgentes Sur número 11 bis, el 29 de septiembre.

Datos biográficos del artista: Fidel Corpus Nava nació en México, D. F., estudió en la Escuela Nacional de Pintura y Escultura La Esmeralda, de 1964 a 1970.

LA COLECCIÓN DE ARTE GRÁfico meXicano. Exposición de las obras pertenecientes a General Motors de México, presentada por el Instituto Mexicano Norteamericano de Relaciones Culturales, A. C., Galerías Nabor Carrillo y Nuevos Valores, Hamburgo 115 , el 30 de septiembre.

manuel manilia. Exposición de 330 grabados originales, presentada por la Galería Arvil, Hamburgo 241, el 30 de septiembre.

rRANCisco moreno cafdevila. Exposición de aguas fuertes, presentada por la Fundación Cultural Miguel Cabrera, Calle de García Vigil 818, Oaxaca, Oax., el 18 de septiembre.

Datos biográficos del artista: Francisco Moreno Capdevilla nació en Barcelona, España en 1926. Reside en México desde 1939. Profesor titular de la Escuela Nacional de Artes Plásticas de la UNAM desde 1958; clases de pintura, dibujo y grabado.

FRANCIsco zúÑ̃ga. Exposición de esculturas y dibujos, presentada por la Fine Arts Gallery of San Diego, Balboa Park, San Diego, Cal., el 10 de septiembre. E. U. A.

FLlzabeth Millioud. Exposición presentada por The Emerson Gallery, 17230 Velltura Boulevard, Encino, Cal., E. U. A., durante el mes de septiembre.

Al contemplar las diversas creaciones de Elizabeth Millioud, todo se puede ocurrir menos que hayan sido realizadas por una artista autodidacta. $\mathrm{Y}$ es que cuando se unen y sintetizan cualidades auténticas y extraordinarias el resultado es del más alto nivel estético.

E:izabeth Millioud inició su carrera artística como pintora y en este aspecto sus obras ya mostraban un claro talento para el abstraccionismo; primero con mayores recuerdos de las formas naturales y después con una franca expresión no-objetiva, en lá que lucían su fino sentido del color y de la creación formal.

Clara y naturalmente la artista ha seguido sus motivaciones personales sin dejarse perder por el canto de las sirenas. La línea del arte abstracto es la que ha hecho propia y en ella se mueve con aparente facilidad. Pasó de la pintura al arte 
de los tapices, que siguen siendo pintura, si bien tejida, y es en ellos que su personalidad se desenvuelve en elegantes líneas y combinaciones de colores que producen los efectos más atractivos, siempre dentro de ritmos que muestran su notable sensibilidad y su talento.

Cuando Elizabeth Millioud entró de lleno a la escultura había ya probado sus posibilidades creadoras, por lo que no extraña que sus obras en este campo resulten una serie de buenos éxitos. Tiene una maravillosa intuición para encontrar la forma adecuada al material que utiliza, ya sea mármol, ónix o bronce, y consigue realizar lo que todo arte debe ser, o tener: clara concepción de la forma, sensibilidad para manejarla e imaginación para que resulte síntesis verdadera de lo que el artista se propone. Las esculturas de Elizabeth Millioud son como joyas ricas y sensuales, por lo que se antoja acariciarlas. Son cantos, por lo tanto poesía, de diferentes tonalidades; aquí brilla el bronce pulido, reverberante; allá se encuentra el solemne mármol negro, los alabastros virginales, opacos o brillantes, los tonos extraños de piedras antes no vistas, y los graves acentos del bronce verde, mate, que apenas si deja entrever sus entraías de oro.

Mas cuando se fija la atención sobre cada una de las esculturas engolosina la variedad de fornas, siempre resueltas en el punto preciso, en la combinación justa. Hay que resistir la tentación de asociar ideas o imágenes naturalistas a esas formas que, por otra parte, son tan sugerentes que excitan la imaginación del espectador en varios sentidos; ese es su poder. Insisto en que la artista sabe cómo hacer cantar los materiales por medio de su propio canto, que es suave o fuerte, dúctil o de corte abrupto pero sin aristas, según conviene a su estado de ánimo, y a la armonía que no pierde de vista jamás.

Artista recatada, llena de vida interior que deja escapar en sus creaciones, Elizabeth Millioud tiene distinción y elegancia naturales porque provienen de su refinado espíritu y de su sensibilidad "domesticada"; por todo ello es admirable y excepcional en estos días que corren, en que la vulgaridad o las invenciones intelectuales pasan como arte. Esta artista de tan variadas posibilidades puede aún alcanzar niveles más altos, que sin duda escalará por los pasos debidos, porque en ella todo es autenticidad.

Justino FERNÁNDEZ

\section{OCTUBRE}

SALÓN dE GRABado 1971. Exposición presentada por el Salón de la Plástica Mexicana, INBA, Havre $N^{\circ} 7$, el 4 de octubre.

GRUPo UltrA. Exposición colectiva presentada por el Departamento del Distrito Federal, Dirección General de Acción Cultural y Social, Galerias de la Ciudad de México, Alameda Central, Sala Juárez del 5 al 16 de octubre.

Nombre de las expositoras: Delfina Vargas, Susana Carlson, Karin Kirchfeld, Amalia Franco y Eva Laura Moraga.

olga costa. Exposición de pinturas, presentada por la Galería de Arte Mexicano, Milán 18, el 5 de octubre. 
RICHARD R. BENDA. Exposición de 30 pinturas y dibujos presentada por el Instituto Francés de América Latina, Río Nazas 43, el 6 de octubre.

IRMa Domínguez. Exposición de óleos, presentada por el Departamento del Distrito Federal, Dirección General de Acción Cultural y Social, Galerías de la Ciudad de México, Alameda Central (Sala Hidalgo), del 6 al 29 de octubre.

PRIMER SALÓN DE LA Historieta meXiCANA. Exposición pasado y presente de una rama de la ilustración artística, presentada por el Instituto Nacional de Bellas Artes, Depto. de Artes Plásticas, Palacio de Bellas Artes, Sala Verde, el 7 de octubre.

CARTEles internacionales SOBRe seguridad social. Exposición que presenta el Lic. Alberto Híjar, bajo el patrocinio del Departamento del Distrito Federal, Dirección General de Acción Cultural y Social, Galerías de la Ciudad de México en el Centro Social Popular José Ma. Morelos y Pavón, Lago Trasimeno y Lago Erne, Col. Pensil, del 7 al 29 de octubre.

¿Para qué sirve el cartel? La industria de la cultura ha impuesto un conjunto de medios de difusión con propósitos mercantiles. La propaganda nos aturde hasta convertirse en la única manifestación pública de nuestros días. Con la efectividad publicitaria, debidamente apoyada por la moral publirrelacionista, usa los efectos del arte de ayer bajo la reaccionaria consigna de sacralizar lo viejo por conocido.

En algunos paises, la cultura popular no se restringe a la pugna mercantil, sino que resiente el impacto de creadores que han rebasado el cerco de galerías comerciales, museos y cocteles, para usar sus habilidades al servicio de causas obreras. Otros países han superado la etapa de la producción de objetos para el mercado y empeñados en la producción de satisfactores realmente humanos, promueven la difusión de ideas progresistas en los centros de trabajo. El cartel de cada país es un indicador para advertir los intereses reguladores de su sistema: los de la compraventa o los del progreso humano.

El cartel de seguridad e higiene del trabajo industrial resulta especialmente interesante en cuanto puede servir a dos funciones antagónicas según el sistema patrocinador: la protección de la maquinaria o la protección del trabajador. La síntesis de la forma, la claridad en el uso del color y de los símbolos, sólo pueden ser enjuiciados válidamente en estos carteles como formas de uno u otro contenido.

Esta exposición pretende estimular el desarrollo del cartel a sabiendas de la inarmonía de los factores de la producción, de la preocupación creciente entre los artistas por incorporarse a un trabajo popular, de la resistencia de las organizaciones sindicales por alentar la conciencia crítica y del control oficioso de la propaganda. Pero lejos estamos de proponer que el cartel deberá esperar el cambio social para desarrollarse. Con sus propias posibilidades, los cartelistas pueden y deben contribuir al desarrollo del hombre nuevo y a la destrucción de lo viejo.

Alberto Híjar S.

SUSANA campos. Exposición retrospectiva de grabado, presentada por el Departamento del Distrito Federal, Dirección General de Acción Cultural y Social, Gale- 
rías de la Ciudad de México en el Centro Social Popular Leandro Valle, Av. Sur 8 y Oriente 241, Col. Agrícola Oriental, del 7 al 29 de octubre.

Datos biográficos de la artista: Susana Campos, nació en la ciudad de México. Inició sus estudios de Artes Plásticas en el año de 1958 en el Instituto Italiano Dante Alighieri. De 1962 a 1965 realizó estudios en la Escuela Nacional de Artes Plásticas en la U. N. A. M.

Ieticia tarragó. Exposición presentada por la Galería Plástica de México, Londres 139, del 7 de octubre al 6 de noviembre.

Catálogo: Pinturas: 1. unisex 2. escena urbana 3. tres figuras 4. el cuarto de juegos 5. figura con bebé 6. cartel de circo 7. aviación 8. luz eléctrica 9. futbolista 10. la casa 11. la televisión 12. extraños amigos Dibujos: 13. uno bis 14. dos bis 15 . tres bis 16. cuatro bis 17 . cinco bis 18 . seis bis 19. caballitos Gouaches: 20. televisión 21. futbolista 22. lo imprevisto 23. casa Grabados: 24. lo imprevisto 25. peces 26. paisaje con figuras 27 . el circo 28 . la playa 29. nuestro querido Albertito 30. muñeca número 2.

MIgUel herNÁNDEZ URBÁN. Exposición de obras, presentada por el Departamento del Distrito Federal, Dirección General de Acción Cultural y Social, Galerías de la Ciurlad de México en el Centro Social Popular Gral. Ignacio Zaragoza, Av. Oriente 154 , y Calle Sur 121.

Díaz CAÑEDo. Exposición de grabados y dibujos, presentada por el Departamento del Distrito Federal, Dirección General de Acción Cultural y Social, Galerías de la Ciudad de México en el Centro Social Popular "Aquiles Serdán”, Puerto Tampico número 4, esquina Puerto Guaymas, Ampliación de la Col. Casas Alemán, del 8 al 29 de octubre.

Baruj Salinas. Exposición de óleos, presentada por el Instituto Nacional de Bellas Artes, Depto. de Artes Plásticas, Embajada de los Estados Unidos de América, Palacio de Bellas Artes, Sala Internacional, el 8 de octubre.

Datos biográficos del artista: Baruj Salinas, nació en La Habana, Cuba, en el año de 1935. Se graduó en la Kent State University, Ohio, en Arquitectura en 1957.

Catálogo: 1. desprendimiento, óleo s/tela $.91 \times 1.17 \quad 2$ crisálida, $91 \times 1.17$, óleo s/tela 3. el hombre roto, $.91 \times 1.17$, óleo s/tela 4. rompiendo las cadenas, $1.17 \mathbf{x}$ 1.17 , óleo s/tela 5 . cl retorno de los olvidados, $1.17 \times 1.17$, óleo s/tela 6 . acoplamiento en el espacio, $1.07 \times 1.07$, óleo s/tela 7. últimos vestigios de humanidad, $1.07 \times 1.07$, óleo s/tela 8. órbita naranja, .76 de diámetro, óleo s/tela 9. ihomb’e o máquina?, 76 de diámetro, óleo s/tela 10 . el mar: odisea óptica, $1.27 \mathbf{x}$ 1.52, óleo s/tela 11. visión fantasmagórica del hombre, $1.22 \times 1.52$, óleo s/tela 12 . la condena, $1.22 \times 1.47$, óleo s/tela 13. desencuentro, $1.06 \times 1.32$, óleo s/tela 14. búsqueda del metamundo, $1.06 \times 1.32$, óleo s/tela 15 . polvareda cósmica, $1.06 \mathrm{x}$ 1.32 , óleo s/tela 16. cantera prinitiza, $1.06 \mathrm{x} 1.27$, óleo s/tela 17. génesis, 1.06 x 1.32, óleo s/tela 18. proyección esférica, $1.06 \times 1.27$, óleo s/tela 19 . la caverna resplandeciente, $1.06 \times 1.27$, óleo s/tela 20 . mosaico magnético, $1.06 \times 1.27$, óleo s/tela 21. fisonomía del trasmundo, $1.06 \times 1.27$, óleo s/tela 22. equilibrio de la escncia, $1.22 \times 1.47$ óleo s/tela 23. Jaberinto calcáreo, $1.06 \times 1.32$, óleo s/tela 24. granulación nuclear, $1.06 \times 1.32$, óleo $\mathrm{s} /$ tela 25 . encrucijada, $1.22 \times 1.22$, óleo s/tela. 
AnTonio suárez. Exposición de obras recientes, presentada por la Galería Arvil, Hamburgo número 241 , el 11 de octubre.

Pálo o'higgins. Exposición-Homenaje, presentada por el Instituto Nacional de BeIlas Artes, Depto. de Artes Plásticas, Palacio de Bellas Artes, Salas 1, 2, 3, 4 y 5 , el 13 de octubre.

Cuando denominamos esta exposición, "Presencia de Pablo O’Higgins en la pintura mexicana", reiteramos con ello el sentimiento fraternal que nos mueve la obra de un artista que, por más de cuatro décadas, ha realizado entre nosotros la fecunda tarea de expresar plásticamente su visión de este país, no sólo como espectador del fenómeno geológico, sino también en el social y humano.

Con el negro del lápiz o la tinta, ha dibujado por millares los rostros del pueblo sobre la tierra sedienta. Allá y acullá ha dejado múltiples estampas trazadas con mano firme sobre la piedra litográfica o incididas sobre la madera y el linóleo, lıa subido sobre el andamio para pintar sobre los muros cívicos y ha proliferado también sobre el caballete, acuarelas y telas polícromas en un afán de aprisionar nuestro mundo, el mundo que le rodea y aquel que un día, desde hace ya muchos días, ya no quiso dejar.

Por esta entrega, por esa presencia suya en momentos significativos para el arte mexicano, que sería obvio mencionar en estas líneas; por el recuerdo de aquéllos, ahora ya desaparecidos a quienes un día acompañara en la aventura de la creación, esta exposición que ahora realiza el Instituto Nacional de Bellas Artes tiene el valor de un reconocimiento y segiramente que tendrá eco en todos los que aman el arte, cono voz pura y límpida expresión del hombre.

El caso de O'Higgins no es el único en la historia de la pintura mexicana de este siglo, nombres de artistas tan distinguidos como Carlos Mérida, Máximo Pacheco, Remedios Varo, Souto, Rodríguez Luna, Leonora Carrington, Jean Charlot, Kitagawa, Koloman Sokol y tantos que sería largo enumerar, se han sumado al caudal cle nuestra plástica, la que adquiere así una dimensión universal, sin perder la expresión vigorosa de su personalidad.

Alfkedo Guati Rojo

La pintura mural de México laa alentado las grandes luchas de su pueblo, las ha nagnificado. Es un llamado a perseverar en el camino rudo y lleno de peligros que las masas deben recorrer para lograr sus propósitos de emancipación nacional y social. Creo que esa gran misión de la pintura mural debe darse a conocer y valorizarse con justeza. Otra enseñanza para todos es la conducta de los pintores, que discutieron, que pelearon inclusive por sus concepciones, pero nunca alejados de la gente ni ajenos a sus preocupaciones, a sus dolores, a sus esperanzas. Ni Diego Rivera, ni José Clemente Orozco, ni ninguno de nosotros hubiera realizado lo que ha hecho sin esa comunión con el pueblo, sin el apoyo de los mexicanos, sin la comprensión del gobierno surgido de la Revolución, sin el aliento de los compañeros. Qué diferencia entre México, un país pobre, lleno de carencias, pero sensible, creador, rebelde, con países ricos, pero sordos a las grandes empresas del hombre en el arte.

Pablo O'Higgins 
Perfil vital y artístico de un noble pintor. Una de las demostraciones más destacadas de la evidente trascendencia que alcanzó el moviniento renacentista del arte en México fue indudablemente su repercusión efectiva en el exterior; concretamente sobre todo, y de gran significación, en nuestro país vecino, los Estados Unidos de Norteamérica.

La influencia de este hecho que logró una simbiosis de idiosincrasia, tradición y nuevos anhelos y experiencias, al renovar y llevar a cabo en gran escala, la olvidada pintura mural, al iniciarse un cambio en la vida de México, no sólo es un hito importantísimo en nuestra trayectoria, sino en otros países de América, que supieron también apreciarlo y arovecharlo. No hay que hablar, por supuesto, del impacto causado en el resto del mundo; de ahí que no cause sorpresa que por caminos diversos, uno de los principales ayudantes de Diego Rivera, en un principio - junto con el guatemalteco Carlos Mérida- haya sido el francés Jean Charlot.

Pero el caso de Pablo O'Figgins viene a constituir un reconocimiento más profundo del significado y los valores de la escuela mexicana, a la cual se adhirió entrañablemente, desde el primer momento en que le fue dado llevar a cabo, a través de Diego Rivera su incorporación absoluta a las tareas comunes y al ideario que las propiciaba.

Para él fue este episodio una conquista definida que colmaba satisfactoriamente sus propias aspiraciones. Para México, su entrega en todos los órdenes, ha sido una conquista que nos honra, por el lugar que ha conseguido adquirir en lo más genuino de nuestro ser.

Aparte de su interés ell compenetrarse -como lo la hecho- al sentido más esencial del mexicano, me parece que existen ciertos ángulos en él que justifican su plena identificación con el ambiente y la criatura de este suelo; su estirpe céltica en que se rastrean curiosas coincidencias con el espíritu inquieto y a la vez paciente del pueblo que ha retratado tan fiel $y$ amorosamente en sus imágenes en muros, lienzos y estampas gráficas.

Quien ya traía consigo -en los años veinte- conocinientos y herramientas probadas, lia ido acendrando a lo largo de poco más de cinco décadas, su concepción del muido -su Weltanschauung- y su personalísima escritura técnica. La firmeza y palpitación que se observan en sus menores bocetos lo califican de dibujante incisivo y concreto; un verdadero maestro, pues en tales apuntes, y dibujos más definidos, están las simientes fértiles de sus obras mayores.

Los proyectos para su gran acervo de obras murales, aquí y en el extranjero, son testimonios de su acucioso método constrnctivo, así como de la claridad de su pensamiento creador.

Es muy natural que, en los inicios de su quehacer artístico entre nosotros, se esfuerce a una suerte de adaptación voluntaria, para no disentir de la orientación general pactada colectivamente, con más o menos variantes. Se le advierten, aquí y allá, trazos influidos acaso inconscientemente, por Diego Rivera y aun por Orozco. Más, gradualmente, con una constancia y dedicación envidiables, ha de irse abriendo camino hasta llegar a su propio estilo, en el que existen voces nuevas derivadas de una suma de experiencias anteriores y de las emprendidas en contacto con las actividades del grupo mexicano, del que forma parte entusiasta.

El temario de O'Higgins la sido siempre y sigue siendo la vida del pueblo trabajador, el pueblo pobre. No le atrac el clima falso e hipócrita de la sociedad en que 
viven los ricos. Su naturaleza, de hombre hondamente saturado de bondad humana, le coloca en estrecha convivencia con los que han menester de justicia y de pan; y en eso se halla justamente dentro de los lineamientos de la primera época de la pirtura mexicana del siglo $\mathrm{xx}$. Como excepción y con perfiles magistrales hay que señalar su retratística. Aun en este capítulo el obrero y el campesino le han facilitado plasmar obra de gran reciedumbre, que asimisno ha sabido reflejar en fidelísimas efigies de su propia esposa - María-y de amigos intelectuales y artistas.

Caracteriza a O'Higgins, más que nada, su incesante búsqueda encaminada a integrar, en su pintura y grabado, a la tierra con el hombre. En ese proceso se va fácilmente descubriendo como lo ha logrado, poco a poco, hasta llegar a una síntesis llena de fuerza emocional, por su aliento avasallador. No se puede concebir en su fecunda obra ninguna separación entre ambos factores que se completan y se influyen mutuamente. La fisonomía de uno y otro tienen una ligazón muy profunda y el pintor que es O'Higgins entendió de mođo sorprendente este fenómeno, que resalta de modo ostensible en el agro mexicano, principalmente.

De modo paralelo a su firme voluntad de forma, $\tan$ clarividente $\mathrm{y} \tan$ bien sentida, la paleta cálida de hace años se ha ido transformando en una luminosa y vibrante armonía de tonos, que configuran en lo que plasma, una atmósfera húmeda y alegre, resplandeciente, saturada de esperanza. Usa texturas sobrias en forma de planos que se desarrollan, preferentemente en líneas onduladas, nunca en aristas.

En el paisaje, gradualmente, llega a convertir su iniagen del maguey en un símbolo, y más que eso: un ser viviente, cuyos puntiagudos brazos extendidos en un movimiento de espiral, semejan rasgos humanos. La orografía de la tierra es algo vivo, de tremendos contrastes y también ángulos de paz. La presencia del hombre es siempre acertada y conmovida connotación vital al lado de la amplitud sohrecogedora del conjunto.

Punto esencial del arte de O'Higgins es su fuerza de expresión, patente en la solidez de los volúmenes y en la definición de los contornos y los términos, de tal modo que aun en sus originales cuadros de flores, obtiene efectos estructurales que parecen salidos del escoplo. No hay nada vago, ni preciosista, sino un discurso diáfano, obịctivo, sencillo, de una sobriedad en los valores lumínicos, que causa la más sincera e intima impresión.

Es un orgullo para nosotros tener en el seno de nuestra evolución artística independiente, a un hombre de tan elevada talla moral, física y eminentemente creadora.

\section{Jorge J. CRespo de la Serna}

Catálogo: 1. estudio figura (obrero) 1924, $21 \times 39$, lápiz 2. estudio de lechuga, 1924, $30 \times 23$, lápiz 3. paisaje de Xochimilco, $1924,30 \times 23$ lápiz 4. Ixtapalapa, 1924, 30 $\times$ 23, lápiz 5. vista de Ixtapalapa. 1924. $29 \times 22$, lápiz 6. dos maternidades, 1924, $22 \times 29$, tinta 7. Cerro de la Estrella, 1924, $34 \times 22$, lápiz 8. caída de agua en Cuernavaca, 1924, $22 \times 29$, lápiz 9. paisaje de Cuernavaca, 1924, $34 \times 22$, lápiz 10. estudio cargadora, $1924,26 \times 20$, lápiz 11. estudio (hombre). 1924, $26 \times 35$, lápiz 12. estudio mujer sentada, 1924, $16 \times 21$, lápiz 13. campesina de Tesonucan, 1924, $21 \times 16$, lápiz 14. retrato de Tina Modoti, 1925, $21 \times 28$, lápiz 15. estudio para cuadro, $1925,35 \times 50$, crayón 16. estudio de árbol, 1925, $22 \times 29$, lápiz 17. paisaje de Cuernavaca, 1925, $34 \times 22$, lápiz 18. follaje, 1925, $22 \times 29$, lápiz 19 . estudio (mujer), 1925, $23 \times 22$, lápiz 20. planta estudio, 1925, $22 \times 34$, lápiz 21. pai- 
saje de Cuemavaca, 1925, $22 \times 34$, lápiz 22. joven con sombrero, 1926, $15 \times 22$, lápiz 23. en la pulquería, 1926, $22 \times 28$, tinta y lápiz 24. vista de Irtapalapa, 1926, $29 \times 22$, lápiz 25. mujer con sombrero, 1926, Los Angeles, Calif., 23 x 31, lápiz y acuarela 26. mujer con sombrero, 1926, Los Angeles, Calif., 25 x 32, lápiz y acuarela 27. cabeza, 1926, $24 \times 31$, lápiz 28. cabeza, 1926, $24 \times 31$, tinta 29. estudio (retrato), 1927, $21 \times 26$, lápiz 30. estudio de manos, 1927, $26 \times 20$, lápiz 31. la crítica, $1928,25 \times 23$, lápiz 32 . retrato de Rafael Carrillo, $1929,11 \times 17$, lápiz 33. estudio León Venado, 1929, $21 \times 28$, lápiz 34. 32 dibujos a lápiz, $12 \times 7$, de 1924 a 1930 35. dos hombres, $1930,29 \times 52$, lápiz 36. estudio hombre con gorra, $1930,35 \times 48$, lápiz 37. 31 dibujos, $12 \times 7$, de 1930 a 194038 . retrato de Elena Yásquez Gómez, 1932, $28 \times 40$, lápiz 39. en el túnel (Nueva York), 1932, $45 \times 35$, acuarela 40. composición, Nueva York, 1932, $30 \times 23$, tinta 41. en la fundición, $1933,29 \times 53$, lápiz 42.2 proyectos para mural en la Escuela Primaria "Emiliano Zapata", México, D. F., 1933, $56 \times 47$, lápiz 43. boceto para mural en la Escuela Prinaria "Emiliano Zapata", México, D. F., $1933,12 \times 14$, lápiz 44. proyecto para mural en la LEAR, $46 \times 49,1936$, lápiz 45. proyecto para mural en el mercado "Abelardo L. Rodríguez", 1936, México, D. F., $250 \times 76$, lápiz 46. boceto para mural en el mercado "Abelardo L. Rodríguez", 1936, México, D. F., $250 \times 76$, lápiz 47. boceto para mural en el edificio de Tallercs Gráficos de la Nación, México, D. F., 1936, $58 \times 32$, lápiz 48. boceto para el mural en el edificio de Talleres Gráficos de la Nación, México, D. F., 1936, $79 \times 1.05$, lápiz 49. boceto para mural en cl edificio de Talleres Gráficos de la Nación, México, D. F. 1936, $79 \times 1.05$, lápiz 50. estudio brazo, $1936,39 \times 57$, lápiz 51 . retrato de Leopoldo Méndez, $11 \times 17$, 1937, lápiz 52. estudio (hombre desnudo), 1937, $43 \times 59$, lápiz 53. dos proyectos para mural en la Escuela Secundaria "Estado de Michoacán", de México, D. F., 1938 (alegoria a la expropiación petrolera), $24 \times 28$, lápiz 54 . apunte para mural en la Escuela Secundaria "Estado de Michoacán", México, D. F., 1938, $12 \times 17$, lápiz 55. estudio (Manuel), 1938, $50 \times 66$, lápiz 56. retrato de Alfredo Zalce, 1939, $11 \times 17$, lápiz 57. retrato de Connie Kahn, 1939, $11 \times 17$, lápiz 58 . retrato de la Sra. Cossio de Pomar, 1939, $11 \times 17$, lápiz 59. retrato de Jesús Díaz, 1939, $16 \times 22$, lápiz 60. retrato de Elsa Rogo, 1939, 23 × 30, lápiz 61. 30 dibujos, $12 \times 7$, de 1940 a 1950 62. niño (Toñito), 1940, $35 \times 47$, tinta 63. estudio, 1941, $19 \times 26$, lápiz 64, ladrillera, 1941, $26 \times 14$, lápiz 65 . retrato de Gene Whitaker, 1943, $11 \times 17$, lápiz 66. retrato de Ana Segher, 1943, $49 \times 60$, lápiz, 67. maguey, 1943, $26 \times 14$, lápiz 68. estudio (Veracruz), 1943, $26 \times 14$, lápiz 69. Nautla, 1944, $26 \times 14$, lápiz 70 . soldador, $1945,35 \times 56$, acuarela 71 . seis bocetos para el muro de Seattle, Wash. E. U. A. diferentes medidas, 1945 72. ladrillero, 1946, $26 \times 14$, carbón 73. cabeza, 1946, $26 \times 14$, lápiz 74. ladrillero, 1946, $26 \times 14$, carbón 75. grupo, 1946, lápiz 76. dos figuras, 1947, $24 \times 16$, lápiz 77 . proyecto para mural en la Escuela Primaria del pueblo de Santa María Atarasquillo, Edo. de México, 1949, $100 \times 50$, lápiz 78. siete apuntes para mural en la Escuela Primaria del pueblo de Santa María Atarasquilo, Edo. de México, 1949, $12 \times 17$, lápiz 79. proyecto para mural en la Escuela Primaria del pueblo de Santa María Atarasquillo, Edo. de México, $1949,1.20 \times 88$, lápiz 80.27 dibujos a lápiz, $12 \times 7$, de 1950 a 196081 . proyecto para mural en el edificio del Sindicato de $L . I$. 'W. $V$., Honolulú, Hawai, $1.04 \times 1.51,1952$. 82. proyecto para mural en el edificio del Sindicato de L. I.W. $V$. Honolulú,, Hawai, $1.20 \times 88,1952$ 83. siete apuntes para mural en el Sindicato de L. I. $W . V$. Honolulí, Hawai, 1952, lápiz 84. apunte para mural en el Sindicato de L.I.W. $V$., Honolulú, Hawai, 1952 (retrato de hombre con gorra), $36 \mathrm{x} 43$, lápiz 85. apunte para mural en el sindicato de L. I. W. $V$., Honolulí, Hawai, 1952 (retrato de nujer), $36 \times 43$, lápiz 86. cargador, 1952, $24 \times 16$, lápiz 87 . estudio (mujer), 1953, $26 \times 14$, lápiz 88. retrato de Sarah Jiménez, 1956, $11 \times 17$, lápiz 89. estudio (cabeza), $1957,28 \times 35$, tinta 90 . proyecto para mural en el edificio de la Presidencia Municipal de Poza Rica, Ver., 1958, $83 \times$ 381, lápiz 91. estudio (anciano), 1958, 47 × 50, lápiz 92. estudio (doña Juanita de la Fuente) 1959, $48 \times 63$, crayón 93. retrato de Próspero Saldivar, 1960, $11 \times 11$, lápiz 94. jacal (Oaxaca), 1960, $24 \times 16$, carbón 95. mujer de Cuetzalán, 1960, $26 \times 14$, carbón 96. retrato de Mariana Yampolsky, 1961, $16 \times 21$, lápiz 97. retrato de Ma. de Iesús 
de la Fuente de O'Higgins, 1961, $16 \times 21$, lániz 98. proyecto para mural en el pabellón de la Feria del Libro, 1962, 1.14 x 98, lápiz 99. retrato de María, 1962, 46 × 62, acuarela 100. proyecto para mural en el edifirio del Banco Nacional de Comercio Exterior, 1963 (la vida del pueblo en los mercados), México, D. F., 56 x 61, lápiz 101. apunte para mural en el edificio del Banco Nacional de Comercio Extcrior, 1963 (mercado interior indígena), México, D. F., $14 \times 12$, lápiz 102. retrato de Eulalia Guzmán, $1963,20 \times 14$, lápiz 103. proyecto para mural boda indígena en San Lorenzo Michoacán, 1964, en el Museo Nacional de Antropología, México, D. F., $74 \times 45$, lápiz 104. 2 apuntes para el mural boda indígcna on San Lorenzo. Mich., 1964, en el Museo Nacional de Antropologia, México, D. F., 21 x 23, lápiz 105. proyecto para mural en el Museo Nacional de Antropologia, Dios del Fiuego, México, D. F., 1964 106. paisaje de Santa Martha, Edo. de México, 1965, 35 x 25, carbón 107. madre e hija, $45 \times 60$, acuarela 108 . figura, $1968,31 \times 45$, tinta 109. retrato de niña de Rayones, $N$. L., 1968, $25 \times 35$, lápiz 110. perfil, 1969, $26 \times 14$, carbón 111. retrato de Carmen del Rosario, $16 \times 21$, lápiz 112. retrato de Angel Bracho, $16 \times 21$, lápiz 113. retrato de Angel Ma. Garibay', $16 \times 21$, lápiz 114. retrato de niña (Rosita), $27 \times 36$, carbón 115. estudio de botellas, $31 \times 23$, crayón 116. exhausto, $58 \times 41$, acuarela 117. estudios, $61 \times 48$, carbón 118. estudio (Don Nieves). $24 \times 16$, lápiz 119. pareja, $35.5 \times 30.5$, tinta 120 . barrio de la carbonera (Saltillo, Coah.), $60 \times 49$, acuarela 121. paisaje de Querétaro, 1940, $42 \times 33$, acuarela 122. León Venado, 1942, 53 x 38, acuarela 123. en cl mercado de Cuatzalán, 1971, $31 \mathrm{x} 50$, acuarela 124. campesina (cargadora), 1971, $31 \mathrm{x}$ 50 , acuarela 125. toro cebú, 1924, $16 \times 10$, aguafuerte 126. en la joya, 1924, $10 \mathrm{x}$ 12 , aguafuerte 127. 24 bocetos, Moscí, 1931 128. buenos vecinos, buenos amigos, cartel, col. Taller de la Gráfica Popular 129. homenaje a Silvestre Rezueltas, cartel col. Taller de la Gráfica Popular 130. IV congreso de la CETAL, cartel col. Taller de la Gráfica Popular 131. IV congreso de la CETAL, cartel, col. Taller de la Gráfica Popular 132. 1er. Congreso de Trabajadores Petroleros Latinoamericanos, cartel, col. del Taller de la Gráfica Popular 133. derechos de la clase obrera (calaveras), grabado en linóleo, $23 \times 22$, col. del autor 134. general Láaro Cárdenas, expropiación Petrolera, grabado en linóleo, $23 \times 19$, col. del autor 135 . el adobero, 1942, litografía, $35 \times 28$, col. INBA 136. futbolista, 1942, litografía, $26.5 \times 35$, col. INBA 137. papelero en el zócalo, 1913 litografía, 36 x 45 , col. INBA 138, don Lupito, 1943, $44 \times 27$, litografía, col. INBA 139. el fascismo, 1944, aguafuerte, $21.5 \times 29$, col. INBA 140. don Lupito, 1944, litografía, $44 \times 34$, col. INBA 141. vendedora en el mercado, 1946, litografía, $35.5 \times 28.5$, col. INBA 142. el ladrillero, 1946, litografía, $43 \times 34$, col. INBA 143. el ladrillo y su hijo, 1946, litografía, $36 \times 28.5$, col. INBA 144. la huelga de Cananea, 1946, grabado en linóleo, $29.5 \times 20.5$, col. INBA 145. trabajadores desayunándose, 1947, litografía, $36 \times 45$, col. INBA 146. Lupe, 1948, litografía, $38 \times 32.5$, col. INBA 147. campesina, 1950, litografía, $33.5 \times 26$, col. INBA 148. maguey Topilejo (maguey viejo), 1950 litografía, $39 \times 54.5$, col INBA 140. Caltzonzin, 1950, litografía, $38.5 \times 26$, col. INBA 150. cañero, 1950, litografía, $58 \times 32$, col. INBA 151. lavanderas de Huilulco, 1953, litografía, $43.5 \times 33$, col. INBA 152. casa indigena, 1953, litografía, $31 \times 46$, col. INBA 153. levantando el rastrojo, 1953, litografía, $30 \times 45$, col. INBA 154. cortando caña, 1953, litografía, $33 \times 47$, col. INBA 155. lavanderas de San Baltazar, litografía, $45.5 \times 33.5$, col. INBA 156. la iglesia de Huilulco, 1953 , litografía, $45 \times 33$, col. INBA 157. haciendo el arado, 1953, litografía, $33 \times 46$, col. INBA 158. la campesina de Honolulu, 1953, litografía, $47 \times 33.5$, col. INBA 159. sin título, 1953, litografía, $43 \times 33$, col. INBA 160 . en el mercado, 1954, litografía, $30 \times 40$, col. INBA 161. Presidente Municipal, 1954, litografia, 32 x 46, col. INBA 162. trabajadores, 1954, litografía, $42.5 \times 33.5$, col. INBA 163. albañiles, 1955, litografía, $45.6 \times 36$, col. INBA 164. danzantes de Metepec, 1955, litografía, $43.5 \times 33$, col. INBA 165 . dos mujeres trabajando, 1957, litografía, $40.5 \mathrm{x}$ 31.5, col. INBA 166. el chichicuilotero, 1957, litografía, $44 \times 31$, col. INBA 167. campesina indígena, 1957, litografía, $24 \times 29.5$, col. INBA 168. retrato de la $S r a$. Tenorio, 1958, litografía, $43 \times 29$, col. INBA 169. Mar del Caribe, 1958, litografía, $50 \times 38.5$, col. INBA 170. la carreta, 1965 , litografía, $37.5 \times 66.5$, col. INBA 
171. campesina de Valle de Bravo, 1965, litografía, $53.5 \times 32.5$, col. INBA 172. día de mercado en Cuetzalán, 1965, litografía, $53 \times 44$, col. INBA 173. la peleonera, 1966, litografía, $80 \times 50$, col. INBA 74. el guerrillero, grabado en linóleo, $40 \times$ 31.1 col. INBA 175. el hombre del siglo XX, litografía, $40 \mathrm{x} 30$, col. INBA 176. electricistas, litografía, $45 \times 33$, col. INBA 177. fundición, grabado en linóleo, $17.7 \times 1.34$, col. INBA 178. ayuda mutua, litografía, $31 \times 41$, col. INBA 179 . Ia hilandera, litografía, $44 \times 30$, col. INBA 180 . campesino descansando, litografía, col. del autor 181. il duelo, litografía, col. del autor 182. el regreso, litografía, col. del autor 183. campesino y maguey, litografía, col. del autor 184. carreta, acuarela, $45 \times$ x 61, col. Dr. Fernando Katz 185. vereda de maguey, acuarela, $62 \times 44$ col. Dr. Luis Muñoz Castellanos y Sra. 186. el joven, acuarela, 41 x 59, col. Familia Kahlo 187. vaso ritual del pulque, acuarela, $60 \times 44$, col. Salomón Marcovich y Sra. 188. sin título, acuarela, $56 \times 46$, col. Kurt Berci 189. obrero, 1931, acuarela, $41 \times 32$, col. particular 190. pepenador, 1964 , acuarela, $66 \times 51$, col. Salomón Marcovich 191. caminante, 1964, acuarela, $46 \times 55$, col. Kurt Berci 192. campesino, 1971, acuarela, $28 \times 46$, col. Marcia y Lorenzo Ochoa 193. flores, 1970, acuarela, $70 \times 65$, col. Dr. Koenisberg 194. líder, caravana del hambre, Nueva Rosita Coah., $74 \times 53$, óleo, col. del autor 195. campesino de Cuautla deshojando mais, óleo, $80 \times 60$, col. Mauricio Migliano 196. maternidad, óleo, $80 \times 60$, col. del autor 197. la montaña, óleo, $65 \times 90$, col. Lic. Enrique Felman y Sra. 198. paisaje con tronco, óleo, $74 \times 55.5$, col. Dr. Fernando Katz 199. paisaje, óleo, $90 \times 1.05$, col Ing. Carlos Berea 200. jov'en pepenadora, óleo, col. Isaac Waimberg 201. la vi da, óleo, 110 × 75, col. Dra. María Teresa Vega de Rodríguez 202, tío Juan (estu(lio), óleo. 74 x 55, col. del autor 203. retrato de la Sra. Amalia Riaño de González, óleo, $96 \times 72$, col. Amalia Riaño de González 204. flores silvestres, óleo, $1.06 \times 64$, col. del autor 205. María, óleo, $85 \times 60$, col. del autor 206. nuestro mundo, óleo, 72 x 67, col. Mabilia y Donaciano Cantú 207. retrato de Ana, óleo, $92 \times 67$, col. particular 208. orquídea, óleo, 74 x 53, col. Dr. Mario Lasky 209. jacal, óleo $60 \mathrm{x}$ 85, col. Dr. Mario Lasky 210. carreta, óleo, $96 \times 134$, col. Dr. Mario Lasky 211. paisaje de Tabasco, óleo, $53 \times 74$, col. Isabel y Ana Galván Chávez 212. campesina de Toluca, óleo, $96 \times 72$, col. Lic. Agustín López Munguía 213. danzante (detalle de mural de la Universidad de Morelia, Mich.), óleo, $90 \times 1.38$, col. Salomón Marcovich 214. espera, óleo, 74 x 53, col. Salomón Marcovich y Sra. 215. paisaje de Tacámbaro, óleo, $93 \times 65$, col. Rafael Carrillo 216. retrato del Lic. Ricardo J. Zevada, óleo, $85 \times 60$, col. Lic. Ricardo Zevada 217. paisaje desértico, óleo, $90 \mathrm{x}$ 60, col. Dr. Luis Muñoz Castellanos y Sra. 218. retrato del Ing. Roberto Osoyo Alcalá, óleo, $72 \times 76$, col. Ing. Roberto Osoyo Alcalá 219. naturalza muerta con plato, óleo, $67 \times 72$, col. Ing. Roberto Osoyo Alcalá 220. paisaje de Orizaba, óleo, $90 \times 65$, col. Dr. Fernando Katz 221. pepenador, óleo, $75 \times 56$, col. Sra. Gita Sten 222. la escondida (paisaje de Coahuila), óleo, $90 \times 1.44$, col. Jacobo Gus y Sra. 223. retrato de Enriqueta, óleo, $85 \times 60$, col. Lic. Antonio Salas Ortega 224. bala$d a$, óleo, 8.85 x 4.65, col. Dr. Adolfo González y Sra. 225. el regreso, óleo, $90 \mathrm{x} 46$, col. Dr. Adolfo González y Sra, 226. don Lupito, encáustica, 48 x 41, col. Manuel Alvarez Bravo 227. retrato de Mariana Yampolsky, óleo, $72 \times 67$, col. Mariana Yampolsky 228. flores, óleo, $76 \times 53$, col. del autor 229. la escondida (paisaje de Coahuila), 1971, óleo. 1.44 x 90, col. del autor 230. Maria (estudio en blancos), b́leo, 1.03 x 80, col. María de Jesús de la Fuente de O'Higgins 231. el río, óleo, $74 \times 54$, col. Paul Antebi y Sra. 232. Eva, 1928, óleo, $36 \times 26$, col. del autor 233. cruz de mayo, 1928, óleo, $90 \times 60$, col. Ing. Jesús Valdivia y Sra. 234. escena callejera, 1928, encáustica, $50 \times 40$, col. privada 235. siesta en Tacubaya, 1936, encáustica, $44 \times 64$, col. del autor 236. trabajadores en la madrugada, 1944, óleo, $95 \times 70$, col. del autor 237. trapiche, 1948 , encáustica, $1.02 \times 79$, col. del autor 238 . retrato de Leopoldo Méndez 1953-54, óleo, $85 \times 60$, col. del autor 239 . vendedora de fruta, 1953, óleo, $6.05 \times 39$, col. del autor 240. maguey, 1954, óleo y temple, 80 x 57, col. del autor 241. retrato de José Mancisidor, 1956, óleo, $96 \times 72$, col. Rafael Carrillo 242. Rosalio tejiendo, 1959, óleo, $80 \times 57$, col. Dr. Adolfo González y Sra. 243. campesino y su arado descansando, 1960, óleo, $56 \times 74$, col. Doris Kreifer 244. flores, 1960, óleo, 79 x 61, col. Dr. Adolfo González y Sra. 245. re- 
reducidos a la sencillez de la rueda o del velero (Roger Caillois: Inventurio di am mundo en Remedios Varo. Era, México, 1967). Son justas las descripciones le Caillois y podrian aun prolongarse indefinidamente puesto que el mundo obsesivamente preciso de Remedios se presta a la descripción. Creo que los fundamentos de este mundo son, si vamos a fondo de todos sus cuadros y de las intenciones pintadas $y$ at veces escritas de Remedios, esencialmente dos: el sentido del tiempo (también del movimiento) y el sentido de lo escondido.

III. ¿No es la pintura esencialmente espacio? La pintura es, sin duda, espacial y lo es -espacio mágico, espacio mítico- en la obra de Remedios Varo. Es también obra recorrida por el tiempo y lo es en cuanto anula un tipo de tiempo y crea otro que es verdadero movimiento del espíritu. Giorgio de Chirico fue también un pintor del tiempo - Chirico, tan hermano de Remedios Varo en su magia y sentido del misterio y tan distinto a ella por ser Chirico ante todo, un pintor de la arquitectura y la ruina. Remedios Varo pinta el movimiento. En uno de sus cuadros - - zino de los más hermosos- titulado "La Revelación o el Relojero" vemos - lo ha escrito Remedios en una de sus minuciosas cartas- sicte relojes (un posible octavo reloj nos da la espalda como "mirando" a los otros siete). Los relojes señalan todos la misma hora: las doce y cuarto. Cada reloj es, además, una cárcel donde figurau "el mismo personaje en muy diferentes épocas". Pero las loce y cuarto no es un tiempo que suceda y pase: es tiempo fijo, hecho de distintos tiempos fijos. Un mismo tiempo, en efecto, pero un mismo tiempo que abarca el instante preciso (ésta y no otra hora), en distintas épocas. "No pintó el tiempo -escribe Octavio Paz- sino los instantes en que el tiempo reposa". En efecto, Remedios Varo no pintó el tiempo, pintó el instante, pero el instante no es fundamento del tiempo, es su destrucción. Fijar el instante en "diferentes épocas" es lo mismo que abolir el tiempo. Los lınnbres, encarcelados en el tiempo, se quedan fijos e inmóviles en su instante-époci. Pero los hombres que son capaces de salir del tiempo, se liberan. Salir del tiempo es salvarse, es, en los términos de Remedios Varo, encontrar una "revelación" que va nada tiene que ver con el tiempo instante-época. Con lo cual no quiero decir que Remedios Varo renuncie del todo al tiempo. Crea otra temporalidad capaz de verdaderas revelaciones. Porque, en efecto, el tiempo es el enigma y Remedios Varo podria firmar aquella frase de Chirico escrita en torno a uno de sus autorretratos: "¿Qué amaré sino lo que es enigma?"

El tiempo de la magia y del mito suele describirse como tiempo circular, tienno ć́clico de los eternos rctornos. Una "lectura" superficial de la obra de Remedios podría lacemos pensar que su obra trata únicamente de este tipo de tiempo circular o cíclico. Sería una manera de buscar la eternidad porque, en última instancia, un tiempo cíclico parece prometernos, a pesar de nuestra desmemoriada memoria, la eternidad de nuestras repeticiones en otro tiempo que es este nuestro mismo tiemno eternamente repetido. Y si escribo "sería una manera" lo hago porque me parce que Remedios, si bien pinta un tiempo - un movimiento también- en cierto modo círlico, lo pinta cono ciclo abierto; no como ciclo cerrado. El tiempo de la obra de Remedios Varo es espiral $y$, por lo tanto, trascendente puestu que la espiral crece, asciende y busca sin jamás repetirse.

Recordemos algunos cuadros de Remedios. En "Naturaleza muerta resucitando" la resurrección de la muerte proviene precisamente de un ascenso irregular que aspira a mayor amplitud de su propio círculo. En el extraordinario "tránsito en 
espiral", los valeros -casi pájaros, casi libélulas- caminan reposadamente hacia el mar abierto (¿qué inquietud les espera?), o viajan hacia el centro mágico (¿qué inquieto reposo los aguarda?). Tiempo serpenteante - no cíclico cerrado- el del "Trovador" que con sus ojos es a la vez encucntro y trascendencia del encuentro; la pintura de Remedios Varo es la pintura de un tiempo vivo que anda en busca -tal vez herméticamente- de "algo" que trasciende el tiempo. "Algo" que no somos en nuestras apariencias y evidencias; "algo" que tiene que revelarnos la evidencia real de las cosas. Nos revela la realidad objetiva, es decir trascendente, que nos funda.

IT. ¿Qué pretende revelarnos este mundo ahora ya doblado de magia y de revelaciones? ¿Hacia dónde se dirige y nos dirige? El universo de Remedios Varo es presencia de seres. Es también, y acaso sobre todo, sutilísima presencia de relaciones. Algumas de estas relaciones son negativas en cuanto nos impiden y frenan en nuestra aspiración hacia la "objetividad"; otras son positivas y reveladoras en cuanto nos guían hacia ella.

Irónicamente $-\mathrm{y}$ la ironía es fundamental en esta pintura despierta, vivaz, a veces toda ella juguete- nos dice Remedios Varo que el "mimetismo" es inquietante. En efecto, cuando describe en una de sus cartas el cuadro que precisamente se titula "Mimetismo". Explica: "Éste es un inquietante caso de mimetismo; esa señora quedó tanto rato pensativa e inmóvil que se está transformando en sillón". También es inquietante - divertido $y$ hasta tierno- el caso de Gato helecho donde vegetales y carnes intercambian contagios para confundirse y confundirnos. Igualmente inquietante -igualmente contagio más que contacto- la "Arquitectura vegetal". Pero si los contagios son inquietantes, no lo son menos los distanciamientos y los desdoblamientos.

En "La despedida" nace la soledad de dos alejamientos por calles angostas y el beso y pacto del recuerdo sólo en las dos sombras; en "Fenómeno" camina la sombra (¿la mala sombra?), y queda fijo, ya convertido en figura, el personaje que sueña o muere con los ojos abiertos. A veces, los desdoblamientos nos muestran el mundo al revés. Relaciones todas ellas que nos inquictan porque impiden que se realice nuestra voluntad de trascendencia. Pero si el mundo al revés nos inquieta negativamente, también nos inquieta, nos angustia y nos despierta el revés del mundo, es decir, la necesidad de buscar, más allá de las apariencias -evidencias inmediatasla realidad de lo que es evidencia, es decir, claridad, trascendencia, mundo del espíritu.

En otras palabras, el preciso, claro, misterioso munio de Remedios Varo -todo él prodigio y misterio- nos angustia; también quiere llevarnos más allá de la angustia hacia las revelaciones verdaderas.

Algunas de estas revelaciones son de orden mágico. ¿Hacia dónde se dirigian los barcos espirales?; ¿hacia dónde iba el trovador?; ¿cuál era, no el tiempo cronométrico, sino la revelación que, más allá del tiempo instantáneo (tiempo de épocas), se le revelaba al relojero?; ¿cuál el destino desconocido por los tres personajes que tejen el mismo hilo de luz estelar en Tres destinos?

Todos buscan --o a veces encuentran- algo más que este mundo, este paso, esta fugacidad, este tiempo. La sonrisa muchas veces triste - siempre aguda- de Remedios Varo, es la sonrisa de quien ve en sí misma y en los otros -en la "masa", por ejemplo, tema por excelencia de nuestros días- la incapacidad (¿momentánea?; 
¿definitiva?). Por una y por otra razón simpre angustiosa e inquietante, de buscar $y$ menos aún de encontrar.

Mundo dual y unitario el de Remedios Varo: dual en cuanto separa, a veces con dolorosa nitidez, nuestro alejamiento y nuestra confusión, por una parte, y por otra nuestro interés, secreto, escondido o dado objetivamente como una revelación. Único en cuanto todo parece tender, a pesar de soledades, alejamientos, inquietudes, hacia una forma superior de la unidad donde pactan los contrarios. Mundo real no sólo revés de este mundo sino integración y comprensión de nuestro mundo de las apariencias.

¿En qué se revelan las revelaciones de Remedios Varo?; ¿en qué se dan sus formas muy personales de revelación? Nuevamente en formas de la relación pero relaciones que son ahora formas positivas, iluminadoras del ver $y$ del mirar.

Baudelaire, y muchos pensadores herméticos, desde algunos gnósticos hasta los rosacruces del siglo XVIII, pensaban que el mundo está hecho de "correspondencias". Inscribo a Remedios Varo en esta tradición que no dudo en llamar religiosa, aun cuando su religiosidad lleve también por nombres "mito" y "magia". Algunas correspondencias son faisas correspondencias (son falsos los contagios, son falsas las incomunicaciones). Otras son formas de cavar en la realidad para vivir verdaderos encuentros.

¿Qué busca todo lo que busca -y en la obra de Remedios Varo casi todo es búsqueda-? Ella misma lo dice en una palabra de reminiscencias clásicas y, yo diría, pitagóricas y platónicas: la armonia. En el cuadro que lleva este título, "el personaje -escribia Remedios- está tratando de encontrar el hilo invisible que une todas las cosas; por eso, en un pentagrama de hilos de metal, ensarta toda clase de abjetos..." Los personajes de Remedios Varo buscan no el mimetismo -mundo de las apariencias- sino la verdadera ascensión en una suerte de escala mística que nunca acaba de renunciar a la magia. El mundo real $\longrightarrow$ nuestro mundo contingente y visto como mundo real- está presidido por la crcación ("bajo las órdenes del Gran Maestro, bordan el manto terrestre, marcs, montañas y seres vivos") ; está presidido por la "Ascensión al monte", análogo donde la realidad "real" es precisamente el caracol espiral del monte donde la "simpatía" donde la "analogía", donde tal vez la precisión matemática - ¿ pitagórica?- de La Realidad espera el resultado de nuestro esfuerzo espiritual. Sí, en efecto, la espiral es espera y es esperanza: esperanza de ascenso. ¿Qué preside a las correspondencias entre las cosas? ¿Qué son las correspondencias? Lo que Remedios Varo, en una tradición pitagórica, platónica, a veces hermética, habría llamado la objetividad: "Cuando uso la palabra "objetivo" entiendo por ello que es algo fuera de nuestro mundo, o mejor dicho, más allá de él, y que se encuentra conectado con el mundo de las "causas" y no de los fenómenos, que es el nuestro".

Como en la alegoría platónica de la caverna, aquí todo es voluntad de trascendencia. Como en la alegoría platónica están también aquí las sombras - a veces la mala sombra (¿fue otra cosa el "humor negro" de los surrealistas?)- que lievan a gravedad, confusión y caída. La pintura de Remedios Varo es pintura de las evidencias (de lo que se nos da a ojos vistas) para alcanzar la evidencia que lo aparente esconde. Por esto, para Remedios Varo lo escondido - a veces revelado, a veces visto, siempre sospechado e indicado - es lo verdaderamente real. Y si el mundo de las apariencias es guiado por la nccesidad o es guiado por absurdos inquietantes, el mundo 
de la realidad - de lo objetivo- tiene por principio orden y libertad, matemática imaginada y por lo tanto real, y una forma del azar que es mucho más azoro que casualidad.

Sorpresa, la de Remedios Varo, de que el mundo, por la fantasía y en la fantasía tenga sentido. Pintura, estrictamente hablando, metafísica, o meta-real (es decir suprarrealista) siempre que sepamos que las evidencias en que vivimos son evidencias de sombra; siempre que sepamos que las evidencias-sombra, el tiemioinstante, el momento-época, necesitan de una revelación "objetiva".

RAmón XiRaU

Datos biográficos de la artista: Remcdios Varo, nació en 1913, en Anglés, Espan̄a, liija de padre andaluz, ingeniero de recursos hidráulicos, y de madre vasca. Pronto se revela el talento de Remedios para el dibujo y las matemáticas y empieza sus estudios en la Academia de San Fernando de Madrid. Vive mucho tiempo en París, donde se une a los círculos surrealistas y traba amistad con André Breton, Max Ernst, Leonora Carrington, Tanguy, Miró y otros. De esta época casi no hay obras algunas.

Catálogo: 1. vista al cimujano plástico, óleo s/masonite $.70 \times .35$ colección Dr. Jaime Asch 2. hiedra aprisionada, gouache $.38 \times .32$ col. Sr. Lic. Luis Atristáin 3. creación del mundo, gouache s/cartulina (boceto) $.71 \times 1.22$ col. Dr. Sigfrido Becker 4. robo de sustancia, óleo s/masonite $.58 \times .82$ col. Dr. Sigfrido Becker 5. esquiador, ólco s/masonite $.43 \times .32 \mathrm{col}$. Sr. Alex Berger y Sra, 6 , invocación, vinílica s/cartulina $.49 \times .40$ col. Sr. Alex Berger y Sra. 7. sin título, dibujo a tinta s/papel $.23 \times .16$ col. Sr. Harry Block y Sra. 8 . simpatia, ólco s/masonite $.95 \times 83.5$ col. Sr. Pablo Brenner 9. despedida, óleo s/tela $.34 \times .24$ col. Sr. Pablo Brenner 10. mujer roja (la tejedora), óleo s/tela $43.5 \times 28.5$ col. Sr. Pablo Brenner 11. bordando el manto lunar, dibujo a color $53.5 \times 41$ col. Sr. Pablo Brenner 12. el marqués de la contrecroupe, dibujo a tinta, $27.5 \times 24.5$ col. Sr. Pablo Brenner 13. mujer con niño y paraguas, calca $.28 \times .32$ col. Sr. Pablo Brenner 14. la expedición del agua áurea, calca, $1.06 \times 59 \mathrm{col}$. Sr. Pablo Brenner 15 . el trotrador, calca $.23 \times .37$ col. Sr. Pablo Brenner 16. nacer de muevo, calca $.75 \times .46 \mathrm{col}$. Sr. Pablo Brenner 17. vagabundo, calca 14 x 10.5, col. Sr. Pablo Brenner 18. ruptura, óleo s/masonite $.93 \times .58 \mathrm{col}$. Dr. Atila Camisa 19 . tránsito en espiral óleo s/masonite $1.00 \times 1.15 \mathrm{col}$. Sr. Lic. Luis Carral y Sra. 20. personaje astral, óleo s/masonitc $.70 \times .40 \mathrm{col}$. Dr. Jaime Constantiner 21. visita al pasado, dibujo a lápiz s/papel $.59 \times .55 \mathrm{col}$. Sr. Jorge Juan Crepo de la Serna 22. retrato del Dr. Ignacio Chávez, óleo s/masonite $.93 \times .61 \mathrm{col}$. Dr. Ignacio Chávez 23. fenómeno, óleo s/masonite $.55 \times .40 \mathrm{col}$. Sres. Jacques y Monique Davidoff 24 . encuentro, óleo s/masonite $.70 \times .40 \mathrm{col}$. Sr, León Davidoff y Sra. 25. planta insumisa, óleo s/masonite $.84 \times, 62$ (ovalado, col. Sr. León Dividoff y Sra. 26. la huida (No. 3 del tríptico), óleo s/masonite $1.23 \times .93 \mathrm{col}$. Sra. Cecilia Davis 27. la llamada, óleo s/masonite $1.00 \times .68 \mathrm{col}$. Sr. Ing. Jaime Diadiuk 28. los amantes, mixta s/cartulina .75 x .30 col. Sra. Carmina Díaz de Cossío 29. encuentro, óleo s/tela $.40 \times .30$ col. Dr. Raúl Fournier Villada 30. Invernación, óleo s/tela (dedicado) $.20 \times .27$ col. Dr. Raúl Fournier Villada 31. bordando el manto terrestre No 2 del tríptico) óleo s/masonite $1.23 \times 1.00$ col. Germán García 32. apártalos que zoy de paso, lápiz s/cartulina $51 \times .37$ col. Dr. Roberto Garza 33. banqueros 
cn acción, mixta s/masonite (inacabado) $.61 \times 10 \mathrm{col}$. Srita. Juliana González 34. caza nocturna, mixta s/cartulina $.48 \times .22 \mathrm{col}$. Sra. Alejandra Varsoviano de Gruen 35. mimetisno, óleo s/masonite .48 x .49 col. Sra. Alejandra Varsoviano de Gruen 36. roulotte, óleo s/masonite $.78 \times .60 \mathrm{col}$. Sra.Alejandra Varsoviano de Gruen 37. alquinista o la ciencia inútil, óleo s/masonite $1.05 \times .54$ col. Sra. Alejandra Varsoviano de Gruen 38. tejido de espacio y tiempo, óleo s/masonite $.64 \times .53 \mathrm{col}$. Sra. Alejandra Varsoviano de Gruen 39. música del bosque, dibujo (inconcluso) $89.5 \times .70$ col. Sra. Alejandra Varsoviano de Gruen 40. naturaleza muerta resucitando, calca $1.05 \times .74 \mathrm{col}$. Sra. Alejandra Varsoviano de Gruen 41. tejedora, dibujo a lápiz s/papel (sin firma) $.69 \times .57$, col. Sra. Alejandra Varsoviano de Gruen 42. as del volante (dedicado), mixta s/cartulina $20 \times 21.5$ col. Sra. Alejandra Varsoviano de Gruen 43. guajolote navideño, mixta s/cartulina $.29 \times .25$ col. Sra. Alejandra Varsoviano de Gruen 44. exploración de las fuentes del rio Orinoco, calca $.44 \times .40$ col. Sra. Alejandra Varsoviano de Gruen 45 . las almas de los montes, óleo s/tripaly, .75 x .51, col Sra. Alejandra Varsoviano de Gruen 46. trasmundo, óleo s/tela $43.5 \times .55 \mathrm{col}$. Sra. Alejandra Varsovia110 de Gruen 47. mujer saliendo del psicoanalista, óleo s/tela $.71 \times 41$ col. Sr. Walter Grucn 48. fenóneno de ingrazidad, óleo s/tela .75 x $.50 \mathrm{col}$. Sr. Walter Gruen 49. niño y mariposa, óleo s/masonite $.53 \times .32$ col. Sr. Lic. Agustín Guevara 50. cazadora de astros (dedicado) mixta s/papel, $.48 \times .34$ col. Sr. Lic. Agustín Guevara 51. la creación de las aves, óleo s/masonite $52.5 \times 62.5 \mathrm{col}$. Dr. Manlio Hernández 52. malabarista, óleo s/masonite $.91 \times 1.22$, col. Lic. Ped́ro Hurtado 53. trovador, óleo s/masonite $.37 \times .23$ col. Lic. Pedro Hurtado 54. los ancestros, dibujo a lápiz s/papel $.52 \times .57$ col. Sr. Eduardo James 55 . la calle de las presencias ocultas, dibujo a lápiz s/papel $.50 \times .41$ col. Sr. Eduardo James 56. personaje, óleo s/masonite .58 .5 x .39 .5 col. Sr. Lic. Marcelo Javelly 57. nacer de mevo, óleo s/masonite $.81 \times .47 \mathrm{col}$. Sra. Olga G. de Kabela 58. locomoción acuática, óleo s/masonite $.37 \times .27 .5 \mathrm{col}$. Sr. Lic. Licio Lagos 59. a mi amigo Agustin Lazo, $.33 .3 \times .19$ col. Sr. Arq. Joaquín G. Lazo 60 . sea usted breve, mixta s/cartulina $.72 \times .14 \mathrm{col}$. Sr. Roberto W. Lerner 61. locomoción capilar, óleo s/mosonite $.83 \times .61 \mathrm{col}$. Sr. Roberto W. Lener 62. L'Ecole Buissoniere, óleo $\mathrm{s} /$ masonite $.40 \times .30 \mathrm{col}$. Sr. Juan Martín 63. la ascensión al monte análogo, óleo s/triplay $.67 \times .31$ col. Sr. Juan Martín 64. vagabundo, óleo s/masonite .56 x .27 col. Dr. Manuel Martínez Báez 65. aprendiz de Icaro (dibujo dedicado) lápiz y sanguina $.45 \times .58$, col. Srita. Elvia Martínez Verdayes 66. la expedición del agua áurea, óleo s/masonite $1.22 \times .60 \mathrm{col}$. Srita Elvia Martínez Verdayes 67. correspondances, gouache s/cartón $.44 \times .32 \mathrm{col}$. Sr. Clemente Merger 68. jardín D'Amour, gouache s/cartón .34 .5 x .29 col. Srita. Suzanne Merger 69. hacia acuario, óleo s/tcla $.40 \times .29 \mathrm{col}$. Sr. Lic. Antonio Ortiz Mena 70 . rompiendo el círculo vicioso, técnica mixta $.65 \times 35 \mathrm{col}$. Sr. Lic. Antonio Ortiz Mena 71. el minotauro, óleo s/masonite $.60 \times .30 \mathrm{col}$. Sr. Alfonso Pandal 72. tailleur pour dames, óleo s/masonite $.77 \times .95 \mathrm{col}$. Sr. Arq. Arturo Pani 73. visitante inesperado, óleo $\mathrm{s} /$ masonite $.42 \times .22 \mathrm{col}$. Sra. Ana Mary de Bartlett 74. presencia inesperada, óleo s/tela $.58 \times .40 \mathrm{col}$. Sr. Lennart E. Philipson 75. mísica solar, óleo s/masonite $.91 \times .61 \mathrm{col}$. Sr. Lic. Carlos Prieto 76. flautista, óleo s/masonite $.75 \times .93$ col. Srita Eva Sulzer 77. arquitectura vegetal, óleo s/tela, $.60 \times .45 \mathrm{col}$. Srita. Eva Sulzer 78. el gato helecho, óleo s/masonite $.66 \times .29$ col. Srita. Sulzer 79. el camino árido, vinílica s/cartulina $.59 \times .31 \mathrm{col}$. Srita. Eva Sulzer 80 . luz emergente, óleo s/masonite $.65 \times .28 \mathrm{col}$. Sr. y Sra. Vilner 81 . armonía, óleo s/masonite .74 x .93 col. Sra Marisole Baz Vda. de Wörner 82. ermitaño, óleo s/masonite .89 x .38 col. Sra. Marisole Baz Vda. de Wörner.

antonlo henRique amaral. Exposición del artista Brasileño, presentada por las Galerías Mer-Kup, Molière No 328-C, el 21 de octubre. 
Variaciones en óleo de "La Banana". En la Primera Semana Internacional de Artes Plásticas convocada por la UNESCO.

Salones de Pintura, iscultura y dibujo, 1971. Exposición colectiva, presentada por el Salón de la Plástica Mexicana, INBA/S. E. P., Havre $N^{\top 0} 7$, el 25 de octubre.

Nombre de los expositores: Héctor Ayala, Ernesto Alcántara, Rolando Arjona, Luis Acosta, Raúl Anguiano, Sofia Bassi, Ingel Boliver, Roberto Berdecio, Feliciano Béjar, Guillermo Ceniceros, Gerardo Cantú, Pilar Castañcda, Roberto Cueva del Río, Enrique Echevcría, Arturo Estrada, Manuel Echauri, Pedro Friedeberg, Byron Gálves, Silvia H. González, Vicente Gandia, Lorenzo Guerrero, Miguel Hernánde z Urbán, Makrina Krauss, Julia López, Anador Lugo, Lconel Maciel, Eliana Menasse, Francisco Mora, Francisco Moreno Capdevila, Gustavo Montoya, Leonardo Nicrman, Froylán Ojeda, Angel Pichardo, Mariano Paredes, Feliciano Pcina, Antonio Ramíres, Mario Orocco Rivera, Maka Straus, Adriano Silva, Ma. Elena Tolmacs, Leticia Tarragó, Maria Teresa Toral, Iucinda Urrusti, Fernando Vilchis, Luis Vizuet, José Zuñiga, Antonio Rodriguez de la Serna.

Catálogo: 1. vírgenes $N^{o} 2,1.59 \times 1.40$, óleo s/tela 2. pintura para una Eva, 1.30 $\mathrm{x} 1.70$, óleo s/tela 3 , eclipse de novicmbre, $75 \times 1.00$ óleo s/tela 4 . paisaje de Texcoco, $.54 \times .91$, óleo s/madera 5. meditación, $.80 \times 1.00$ óleo s/tela 6 . infierno, paraíso, $.47 \times .37$, óleo/madera 7. la meditación de Protágoras, $1.22 \times 1.42$, óleo 5/papel 8. eclipse marciano, $1.10 \times 1.83$, técnica mixta 9. composición, $.80 \times 1.20$, óleo/tela 10. aleación plástica, $1.30 \times 1.79$ óleo/tela 11. mariposa de obsidiana, $1.51 \times 1.73 .5$, óleo/tela 12. Cuauhnáhuac, $90 \times 1.50$, óleo/tela 13 . pueblo viejo, $.55 \times .67$ acuarela 14. las estaciones, $1.10 \times .90$, óleo/tela 15 . Paty y su sueño, $.80 \times 1.13$, óleo/tela 16. vista de camino de Cuernavaca, .56 x 1.20, óleo/tela/madera 17. cámara de los siete soles, $49 \times .49$, técnica mixta/cartulina 18. paisaje cósmico $N^{P} 2,1.50 \times 1.90$, óleo/tela 19. demolición, $1.00 \times 1.30$, óleo/tela 20. bodegón rojo $.79 \times .49$, acrílico/tela 21 . estructura, $70 \times 1.12 .5$, óleo/tela 22 . pareja, $1.73 \times 1.22$, acrílico/mazonite 23. valle de los espejos, $1.20 \times .53$, óleo/tela 24. primavera $.46 \times .68$, óleo/cartulina 25 . nopales y montaña, $.24 \times .60$, óleo/ tela 26. no. $1.44 \times 1.45$ óleo/tela 27. paisaje con figura, $.77 \times 1.22$, óleo/mazonite 28. composición en rojo, $1.12 \times .70$, caseína y acrílico 29 . magucyes, $1.30 \times .90$, óleo/tela 30. 8a. evasión del tablero, $67 \times 61.5$, óleo/tela 31. paisaje prehispánico $.90 \times 1.22$, óleo/mazonite 32. rostros, $60 \times$.44, acuarela/papel 33. Naha, $1.55 \times$ 1.54 .534 . la niña, $.50 .5 \times .40 .5$, óleo/tela 35 . la cañada $.74 \times 1.20$, óleo/tela 36 . metamorfosis de la conquista, $1.00 \times 1.22$, óleo/tela (premio adquisición) 37. mar tranquilo, $1.00 \times 1.22$ técnica mixta 38. pueblo, $1.78 \times 1.49 .5$, óleo/tela 39. principio y causa, $1.20 \times 1.50$, acrílico/tela 40 . memoranda, $1.50 \times 1.30$ óleo/tela 41 . el cuarto de juegos, $.40 \times .90$, óleo/tela 42 . romance en la luna $.40 \times .29 .5$ óleo/tela .43. naturaleza muerta, $.50 \times .35$ técnica mixta 44 . la ventana, $1.20 \times 1.00$, acrílico 45. frutera, $.90 \times .62$ 47. aquelarre del carnaval, $1.00 \times 1.75$, óleo/tela.

JESÚS REYES FERREIRA. Exposición homenaje, presentada por el Instituto Mexicano Norteamericano de Relaciones Culturales, A. C., Galería Nabor Carrillo, Hamburgo 115 , el 26 de octubre.

Datos biográficos del artista: Jesús Reyes Ferreira, nació en Guadalajara, Jal., el mes de octubre de 1882.

PEDRo MEYER. Exposición fotográfica ¿Quién estuvo en Avándaro?, presentada por el Instituto Cultural Mexicano Israelí, A. C., Tíber $\mathrm{N}^{9} 12$, el 26 de octubre. 
ARTE Gráfico polaco. Exposición presentada por el Instituto Nacional de Bellas Artes, Depto. de Artes Plásticas, Embajada de Polonia en México, Palacio de Bellas Artes, Sala Verde, el 28 de octubre.

Al presentar las obras más recientes de treintaisiete representantes polacos de las artes gráficas, no tenemos la pretensión de que muestren un panorama completo de lo que está sucediendo en las artes gráficas polacas. Sin embargo, tenemos la esperanza de que los trabajos señalen la amplitud del área dentro de la cual los artistas crean su propia historia. Debe tomarse en cuenta que en arte ningún campo constituye un territorio definitivamente cerrado. Cada fenómeno nuevo y auténtico produce de inmediato una distensión y una variación de sus límites.

En términos generales, la producción de las artes gráficas polacas que corresponde a los íltimos años, ofrece una serie considerablemetıte amplia de posiciones y actitudes.

Dicho estado de cosas no es resultado de especulaciones artísticas ni de una especial fascinación por determinadas tendencias; tampoco obedece a la búsqueda de una fórmula excepcional que exprese las verdades generales. En Polonia, como objetivos fundamentales de todo esfuerzo artístico, están configurados por dos factores: la intensidad de nuestra existencia personal, inmersa en el complicado mundo actual, y el descubrimiento de un "ámbito bien iluminado" - para usar la frase de Hemingway-, realmente nuestro, que sea un sitio que podamos llamar "una propie【lad" sin exageraciones, pero también sin vergüenza.

En cierta medida, el hallazgo de este ámbito se realizó de manera más luida gracias a las tradiciones nacionales que eran determinantes en los creadores de las artes gráficas polacas y sus obras. Las vicisitudes de nuestra historia, especialnente la repartición del territorio polaco que duró más de un siglo, ofrecieron una riqueza considerable de temas, los cuales fueron asimilados por los artistas a tal grado que nuestro arte pudo expresar de una manera levemente estática, las verdades humanas más profundas.

Por todo esto las repercusiones del Romanticismo tuvieron mayores efectos en Polonia que en cualquier otro país, patentizando, ya en el siglo $\mathrm{xx}$, un arte cuyas formas cambiaban dinámicamente gracias a las nuevas tendencias; así quedó particularizado el expresionismo (llamado "formalismo" según la jerga polaca). Esto explica el hecho de que el neofigurativismo, con toda su poética dramática, fuera aceptado tan natural y ampliamente en Polonia.

En lo que se refiere a los medios concretos que intervienen en toda clasificación del arte, resulta obvio que una división escrupulosa tendria que contener signos de un examen realizado sobre un organismo que no sólo está vivo, sino asimistno en estado de evolución y transformación.

Podemos arriesgar una afirmación: los creadores individuales trabajan los clementos de la razón al mismo ritmo que se acercan a los vestigios del posconstructivismo y tienden a seguir la fuerte influencia del expresionismo; la primera tendencia busca las fórmulas más irrefutables y la segunda desarrolla una inclinación por actuar considerando el gesto del cálculo como un elemento dinámico y violento.

Diferentes factores conforman la naturaleza de las artes gráficas polacas. En este reino artístico pucde localizarse, tal como se dijo antes, la neofiguración en la plenitud de su vitalidad, de su biologismo, de sus aspectos dramáticos y de sus obse- 
siones, vinculada a sus búsquedas en los enigmas del destino y en la intervención del hombre y sus complicaciones en el mundo y la vida.

También descubrimos interpretaciones de los principios del surrealismo, entendido éste de acuerdo con su fórmula original; detectamos tanto el afán metafórico de los signos y consecuencias del pop art, asi como relaciones, expresadas en el lenguaje de los signos que se refieren a acontecimientos rudimentarios y universalmente válidos, o bien que se refieren a algún fenómeno inhabitual y fascinante. Contiene, finalmente, ese "algo" que surge a partir de la afirmación de una vida intensificada por el regocijo que se adhiere a la actividad consciente de ejercer una actividad creadora.

Aliora debemos referirnos someramente a la localización geográfica de las artes gráficas polacas. Aclaramos que el uúmero de círculos artísticos activos ha cambiado durante la época de la posguerra. A diferencia de la situación que prevalecía antes de la guerra, cuando Cracovia y Varsovia constituían los dos centros artísticos de mayor dinamismo, el número de núcleos artísticos ha crecido ampliamente en el curso de los últimos veinte años. Cracovia y muy de cerca Varsovia, han mantenido su anterior preponderancia.

Sin embargo, los artistas que viven en otros núcleos, grandes y pequeños, como Bialystok, Lódz, Olsztyn, Poznán, Rzeszow, Bydgoszcz, Gdansk y Sopot, Katowice y Sosnowiec, Lublin, Torun, Wroclaw, etcétera, se han hecho de una creciente influencia, significativa para configurar la imagen general del arte polaco.

Asinismo, artistas provenientes de diferentes círculos se unen y crean nuevos grupos cuyas funciones mantienen un carácter fundamentalmente organizativo. En esta forma, las características generales de la localización geográfica de los grupos coincirlen con la localización pictórica de los círculos artísticos. Ciertas tendencias, por ejemplo las posconstructivistas, pueden ubicarse en Varsovia tanto como en Cracovia, mientras que la línea neofigurativista puede ser descubierta tanto en Cracovia como en Bydgoszcz o Zgierz.

Desde que la Academia de las Bellas Artes dejó de desempeñar el papel de apuntador de estilos resulta más fructífera, y apropiado que los profesores tomen parte en los acontecimientos del mundo artístico desde posiciones de igualdad con sus alumnos, a diferencia de sus anteriores funciones de "guías". Y otra aclaración. A]gunas obras de nuestros artistas, al ser comparadas con las artes gráficas que desarrollan algunos creadores de otros países, pueden dar la impresión de pequeñez si tomamos en cuenta sus dimensiones y su falta de intensidad en los colores.

Ciertamente, las artes gráficas polacas, a pesar de ofrecer un muy buen nivel de diseño, no fueron $y$ aun no son capaces de alcanzar la misma perfección en la técnica de la impresión. La causa principal de este fenómeno parecen ser las peculiaridades del desarrollo de nuestras artes: la atmósfera de constante, persistente discusión con nosotros mismos, en nuestro propio taller, la discusión sostenida con argumentos que proporciona la misma época, la realidad, la plena significación del mundo e incluso el sentido que expresa con precisión el término latino hic et nunc.

Esta peculiar atmósfera de discusión garantiza, en mi opinión, el vigor de nuestras artes gráficas como fenómeno no sólo de importancia cultural, sino, sobre todo, de importancia intelectual. Las artes gráficas, por tanto, devienen como agudo 
reflejo de las sensaciones y actitudes definidas de nuestros contemporáneos: constituyen un registro que en la actualidad puede ser leído y que será sin duda cuidadosamente estudiado en el futuro.

\section{Stanislaw Stopczyk, Historiador de arte}

Catálogo: 1. Boguslawska Joanna pulsador, linóleo, 70 x $50 \mathrm{cms}$. 2. su excelencia el productor, madera, $70 \times 50$ cms. 3. vibrador, madera, 63 x 50 cms. Broniak Zofia 4. larga duración, litografía, $26.5 \times 49 \mathrm{cms}$. 5. retrato, litografía, $43 \times 52$ cms. 6. persuasión Burkiewicz Franciszek 7. cielos sobre montañas, linóleo, 74 x 52 cms. 8. en la cañada, linóleo, 52 x $74 \mathrm{cms}$. 9. volcán, linóleo, $94 \times 60 \mathrm{cms}$. Demski Stefan 10. una ciudad del futuro, 65 x $50 \mathrm{cms}$. 11. paisaje del centro de una ciudad, linóleo, 65 × 50 cms. 12. construcciones en Zerán, linóleo, $65 \times 50$ cms. Detyniecki Mieczyslaw 13. desayuno sobre la hierba, aguafuerte, 48.7 x 44.5 cms. 14. conquistador de la naturaleza, acuarela, $48.7 \times 44.5 \mathrm{cms}$. 15. una decisión dificil, litografía, 60.5 × $45 \mathrm{cms}$. Freudenreich Wojcech 16. transformación 10 , linóleo, $65 \times 50$ cms. 17. a las víctimas de Auschzoitz, linóleo, 65 × 50 cms. 18 . retrato, linóleo, 65 × $50 \mathrm{cms}$. Habdas Edward 19. alegoría del mar, litografía, $43 \times 58 \mathrm{cms}$. 20. mistificación de la vida, litografía, $44 \times 58 \mathrm{cms}$. 21. Alegoría de la vida, litografía, $58 \times 42 \mathrm{cms}$. Jackowski Tadeusz 22 . recolección I, mezzotina, $39 \times 30 \mathrm{cms}$. 23. recolección $I I$, aguafuerte, $60 \times 46 \mathrm{cms}$. 24 . postpensamiento II, limbo, acuarela, $65 \times 50$ cms. Jakubowska Teresa 25. transportados, linóleo, $83 \times 60 \mathrm{cms}$. 26. elevaciones $I I$ linóleo, $85 \times 50 \mathrm{cms}$. 27. meta, linóleo, 75 x 58 cms. Jelonek Anna 28. tiburón, linóleo, 41 x 52 cms. 29. inquietud, linóleo, $35 \times 50 \mathrm{cms}$. 30. lucha $I$, linóleo, $38 \times 51.5 \mathrm{cms}$. Jurgielewicz Mieczyslaw 31. una visita, madera, $26 \times 23$ cms. 32. cerca del fuego, madera, $23 \times 25$ cnus. 33. domingo, madera, $28 \times 23.5 \mathrm{cms}$. Konda Wlodzimierz 34. lucha entre sombra y luz, técnica mixta, $40 \times 71 \mathrm{cms}$. 35. a la mitad del silencio profundo, técnica mixta, $76 \times 53 \mathrm{cms}$. 36. un eco del corazón del mundo, técnica mixta, $35 \times 38 \mathrm{cms}$. Kotkowski Wlodzimierz 37. una ciudad $I I I$, técnica mixta, 32 × 25 cms. 38. una ciudad $I V$, técnica mixta, $33 \times 25 \mathrm{cms}$. 39. una ciudad $V$, técnica mixta, 31.5 x $24.5 \mathrm{cms}$. Kotys-Kublicka Janina 40 . presente $I I$, técnica mixta, $49.7 \times 32 \mathrm{cms}$. 41. confrontaciones $I$, técnica mixta, $49.7 \times 32 \mathrm{cms}$. 42 . aislamiento $I I$, técnica mixta, $49.7 \times 32 \mathrm{cms}$. Kraupe Janina 43. meditaciones, linóleo, $69 \times 41$ cms. 44. horóscopo, linóleo, $42 \mathrm{x} 56$ cms. 45. victoria, linóleo, $66 \mathrm{x} 44 \mathrm{cms}$. Krzywobloki Wojciech 46. conjunto, técnica propia, $74 \times 56 \mathrm{cms}$. 47. lugar en el paisaje, técnica propia, $75 \times 55$ cms. 48. deslizadero, técnica propia, $75 \times 59 \mathrm{cms}$. Lachowicz Andrzej 49. emanación, técnica propia, 73 x $63 \mathrm{cms}$. 50. ginza, técnica propia, 74 × $57 \mathrm{cms}$. 51. dia, técnica propia, 68 x $60 \mathrm{cms}$. Leszczynska-Kluza Danuta 52. almohada, aguafuerte, $78 \times 59 \mathrm{cms}$. 53. nutridor, aguafuerte, $74 \times 57$ cms. Lutomski Zbigniew 54. tactismo III, madera, $82 \times 52 \mathrm{cms}$. 55. tactismo $I V$, madera, 82 x 52 cms. 56. estímulo, madera, 82 y 52 cms. Luszczkiewicz-Jastrzebsha María 57. planta I, metal, $49 \times 52$ cms. 58. largo sueño, metal, $49 \times 37$ cms. 59. lagartija roja, metal, $50 \times 36$ cms. Malina Marian 60 . espalda de astronauta, técnica propia, $65 \times 46$ cms. 61. las ataduras, técnica propia, $47 \times 66$ cnıs. 62. Iulio técnica propia, 46 × $65 \mathrm{~cm}$. Nowacki Andrzej 63. fiel, aguafuerte, $25.5 \times 43.5 \mathrm{cms}$. 64. jaula, aguafuerte, $34 \times 34 \mathrm{cms}$. 65. espejo, aguafuerte, $43 \times 34.5$ cms. Pakulski Josef 66 . ala, litografía, $67 \times 49 \mathrm{cms}$. 67 . vela, litografía, 70 x 51 cms. 68. movimiento en un espacio, litografía, 69 x $48 \mathrm{cms}$. Piotrowicz Edmund 69. en el mar, técnica propia, $50 \times 70 \mathrm{cms}$. 70 . flor negra, técnica propia, $50 \times 70 \mathrm{cms}$. 71. una noche, técnica propia, $50 \times 70 \mathrm{cms}$. Otreba Ryszard 72. miedo VIII, 76 x $55 \mathrm{cms}$. 73. sucesos $I I$, serigrafía, $81 \mathrm{x} 61 \mathrm{cms}$. 74. verano en las montañas, sefigrafía, $85 \times 55 \mathrm{cms}$. Pamula Jan 75. mariposas de la noche, litografía, $58 \times 85 \mathrm{cms}$. 76. figuras doradas, litografías, 40 x $45 \mathrm{cms}$. Rudnicki Tadeusz 77. puerto I, linóleo, $50 \times 70 \mathrm{cms}$. 78. puerto $I I$, linóleo, 50 x 70 cms. 79. puerto III, linóleo, 50 x $70 \mathrm{cms}$. Rybczynski Jacek 80. del 
scrial-disposiciones $I I$, técnica propia, $40 \times 64 \mathrm{cms}$. 81 . del serial-disposiciones $I I I$, técnica propia, $39 \times 57.6 \mathrm{cms}$. 82. del serial-disposiciones $I V$, técnica propia, 39 x 64 cms. Spetto Marek 83. hoja del calendario, técnica propia, $36 \times 81 \mathrm{cms}$. 84. apaga la lámpara, técnica propia, $36 \times 81 \mathrm{cms}$. 85 . una anistad de vacaciones, técnica propia, $36 \times 81 \mathrm{cms}$. Sterek Roman 86. mevo establecimiento, técnica propia, $57 \times 37 \mathrm{cms}$. 87. paisaje con columna, técnica propia, $58 \times 38$ cms. 88. bloques VI, técnica propia, $50.5 \times 35.5 \mathrm{cms}$. Suberlak Stefan 89 . molino de viento $I I I$, linóleo, 72 x $56 \mathrm{cms}$. 90. estudios $I I$, linóleo, $70 \times 55 \mathrm{cms}$. 91. choza $V$, ]inóleo, $71 \times 53 \mathrm{cms}$. Szklarczyk Andrzej 92. flor de acero, grabado, $22.5 \times 31.5$ cms. 93. vigilancia, grabado $19 \times 26.5 \mathrm{cms}$. 94. invasión de profetas, grabado, $17 \times 13.5 \mathrm{cms}$. Sliwinska Ewa 95. cantino con cima blanca, grabado, $65 \times 91 \mathrm{cms}$. 96. en la puesta del sol, grabado, $65 \times 87 \mathrm{cms}$. Wasowska María 97. bloques que caen, grabado, $62 \times 47 \mathrm{cms}$. 98. pelotas de juego, grabado, $60 \times 45 \mathrm{cms}$. 99. vibraciones, grabado, $60.5 \times 47 \mathrm{cms}$. 100 . el primer día, litografía, 62 x $47 \mathrm{cms}$. 101. el scgundo cuadro. litografía, $65 \times 47$ cms. 102. cruzada, litografía, $65 \times 47$ cms. Zajecki Piotr 103. después de la tormenta, técnica propia, 70 x $50 \mathrm{cms}$. 104. corrida, técnica propia, $70 \times 50 \mathrm{cms}$. 105. después de la tormenta $I I$, técnica propia, 70 x $50 \mathrm{cms}$. Zebracki Zbigniew 106. presa, aguafuerte y aguatinta, $69.5 \times 48.5 \mathrm{cms}$. 107. primer desayuno, aguafuerte y aguatinta, $48.5 \mathrm{x} 29 \mathrm{cms}$.

MANUEL manilla. Exposición de 330 grabados originales, presentada por el Departamento del Distrito Federal, Dirección General de Acción Cultural y Social, Museo de la Ciudad de México, el 29 de Octubre.

Se sabe tan poco de la vida de Manuel Manilla, que muchos historiadores del grabado en México, dicen ignorar la fecha de su nacimiento, y sólo Justino Fernández y Víctor M. Reyes, la sitúan en 1830; Jean Charlot, quien fue de los primeros en escribir sobre Manilla, según datos que le fueron dados por Blas Vanegas Arroyo, en sus artículos en Forma y en Estampa, fijó el año de su muerte, a causa de tifo, en 1895. Aunque Erasto Cortés Juárez, por los temas de algunos de sus grabados, la supuso en 1899.

Sea lo que sea, Mannel Manilla fue el primer grabador de la imprenta de Antonio Vanegas Arroyo, y fue el primero en utilizar el buril llamado "velo", de varios hilos paralelo. Y de 1882 hasta su muerte, trabajó intensanente, realizando una obra de más o menos 500 grabados de José Guadalupe Posada; curiosamente, fue éste quien ocupó su puesto en el Taller de Vanegas Arroyo, en 1892.

Sin embargo, aunque menos conocido que st sucesor en la imprenta del editor popular, la obra de Manilla es diversa y magnífica. Grabó corridos, cuentos, novenas, canciones, programas, sucedidos, alfabetos, tipos populares, personajes taurinos, vírgenes, escenas de circo y de magia, calaveras (como la "Tapatía", la "Taurina", la de la Torre Eiffel, la de Don Juan Tenorio...). Hizo juegos como el de los toros, el del circo, de las carreras; ilustró manuales, como el de "Las siluetas o sombras con las manos" y el de la "Técnica Taurina". Famosos son, aunque a veces confundidos con los de Posada, sus grabados de Ponciano Díaz, sus escenas circenses y taurinas, sus carátulas de cuentos, siss representaciones de la vida íntima y callejera... Y si hasta ahora, como he dicho arriba, se sabe poco de su vida y su obra, espero (que esta edición de sus grabados originales, sirva como base para futuras ilvestigaciones, y sirva también para que no sólo se le conozca como el precursor de José Guadalıpe Posada, sino como a su artista, que en la misma linea de aquél, supo ser uno de los grandes narradores de nuestra comedia humana.

HOMERO ARIDJIS 
Catálogo: 1. calavera tequilera 2. Ia calavera cl panteón lo va jalando 3. las calacas 4. calavera de artesanos 5. la torre Eiffel 6. toro embolado con calaveras 7. todititos al panteón 8. calavera infernal 9. calavera torera 10. calazera del tenorio 11. duclo y rumbo al panteón 12. entierros centaveros, garbanceros 13. Ponciuno Diaz 14. banderillas a caballo 15. los colctudos 16. suertes charras y toreras 17. suertes taurinas 18 . la corrida de toros 19 . charros y toreros 20 . banderillas y vara 21. Ia alternativa 22. maromeros y cirqueros 23. cirqueros y maromeros 24. $\mathrm{el}$ anor $y$ las mujeres 25. Ia familia 26. lucha y duelo 27. asesinado y demonios 28. abogado de los pobres 29. los cómicos de legua 30. dentistas y peluqueros lo llevan hasta el panteón 31. aventuras de don Fermico 32. la vida cotidana 33. infierno y demonios para peresosos y viciosos 34. tragedias y terremotos 35. los niños estudiosos 36. los horrorosos 37. corceles y charros 38. cuentos de otros países 39. cazadores banqueteros 40. los pierde el dinero 41. loteria 42. cuentos, pastorclas y lctras 43. sombras chinescas 44. tipos populares 45. los fusilamientos 46. la feria 47. y 48. la bondición de los animales y animales sin bendición 49. cuentos fantasiosos 50. hechos y sucedidos 51. las mil y una noches 52. monarcas y reyes 53. sorpresas y reyes 54 . la bestia feros 55. la bestia feros 56. cuentos de loones 57. cuando ol ferrocarril llegó, el pueblo hasta se incendió 58. brujerías 59. el escudo nacional 60. San Juan de los Lagos 61. la aduana 62. monumento 63, la solterona 64. amor y screnatas 65. don José Maria Morelos y la Catedral de México 66. la Virgen de Guadalupe 67. arte celestial y Obispo 68. la sagrada familia y los santos niños 69. los dolores de la l'irgen 70. Jesús Nazarcno 71. Cristo en la crui 72. la pasión y cl Bautista 73. santos do milagrería 74. imágcnes y culto religioso 75 . sufricndo las penas del infierno 76. porfadas $d c$ cuentos $y$ apuntes 77. portadas de "consejos" $y$ canciones 78. cuentos clásicos 79 . cuentos ejemplarcs 80 . jucgos y cucntos 81. colección de canciones y cuentos 1889-1894 82. pastorclas y cuchtos populares 83. consejos prácticos para el hogar 84. ilusión $y$ mayia 85. valses y canciones 86. vida cotidiana on la ciudad de México 87. la ciudad de México.

exposición bibldo-iconográfica. Presentada por la Biblioteca Nacional, Salas José Ma. Vigil, y por el Movimiento Estridentista, durante los meses de Octubre-Noviembre.

JAvier ARÉvalo. Exposición presentada por la Fundación Cultural Miguel Cabrera, calle Garcia Vigil No 818 , Oaxaca, Oax., el 30 de octubre.

J.jonaldo nierman. Exposición de pinturas y esculturas, presentada por la Asociación del Museo de Arte, El Paso, 1211 Montana, El Paso, Tex., E.U.A., del 3 al 24 de octuhre.

GASTÓN conzÁlez CÉSAR. Exposición forma e imagen, presentacla por la Galería Arvil, Hamburgo $N^{\circ} 241$, del $1^{\circ}$ al 20 de noviembre.

RICHARD R. BENDA. Exposición de acrilicos, collages y tintas, presentada por la Escnela Nacional de Artes Plásticas, UNAM, Sala de Exposiciones, Academia 22, e1 4 de noviembre.

Ángel bracho. Exposición retrospectiva, presentada por el Departamento del 'Distrito Federal, Dirección General de Acción Cultural y Social, Galerías de la Ciudad de México, Alaneda Central, Salas Hidalgo y Juárez, del 5 al 29 de noviembre. 
Joy Lavir.... Exposición de pinturas, presentada por la Galeria de Arte Mexicano, Milán 18 , el 8 de noviembre.

alvar carrullo gil. Exposición homenaje presentada por la Sala de Arte Público, extensión de la escuela Taller Siqueiros, A. C., Tres Picos 29, Polanco, del 9 de octubre al 23 de noviembre.

Hoy 9 de octubre, profundamente eniocionado, vengo de ver la obra auto-enclaustrada, en acto de la más noble modestia, del Dr. Alvar Cartillo Gil.

Cientos y cientos de obras, grandes y pequeñas, de un pintor sensible, dotado de capacidad para la composición, para el color, para la forma, para la fantasía, en búsqueda por alcanzar lo que ya logró o, quizás otro camino. Excelente obra de carácter puramente subjetivo, de utilidad parcial para nuestro movimiento de pintura mural, pero con poderosa fibra creadora.

$\mathrm{Y}$, a unos cuantos pasos, para su goce personal y el de los visitantes, su gran colección privada con obras de Lozada, Orozco, Rivera, Méndez, las mías propias y decenas de las obras de las más importantes pinturas, esculturas, grabadorcs de nuestro país, de Europa, del Japón, de Estados Unidos y de América Latina. Colección que ha partido y regresado, durante años - a través de nuestro Gobierno y Galerías privadas--, en México y en el mundo entero, con su generosidad de Gran Mecenas. Mientras que la del doctor Carrillo Gil, su personal creación, se gestaba y. permanecía modestamente en la oscuridad.

Al salir de ahí sentí la necesidad, la obligación imperativa de rendirle un modesto homenaje - - seguirán otros-, de sus colegas e intelectuales de todas las tendencias, c1 la Sala de Arte que lleva mi nombre. iAdelante, pintor Alvar Carrillo Gil, que su destino como creador tiene una proyección infinita!

¡Sé que usted sacará fuerzas de su voluntad cada vez más indomable y de su gran corazón! i Delante de usted hay una vía sin fin!

Siqueiros $9-10-71$

Datos biográficos: Alvar Carrillo Gil, nació el 6 de julio de 1898, en Opichén, Yuc. Nota: Se exhibirán 100 óleos y collages quc abarcan un periodo de 1953 a 1971.

manuel felguerez. Exposición presentada por la Galetía Juan Martín, Amberes 17 , del 9 al 27 de noviembre.

enrique bryant. Exposición de pinturas, presentada por el Instituto Mexicano Norteamericano de Relaciones Culturales, A. C., Galería Nabor Cartillo, del 9 al 30 de novicmbre.

TEódulo Rómulo. Exposición de dibujos y grabados, presentada por el Instituto Francés de América Latina, Nazas 43, del 10 al 30 de noviembre. 
DOI: http://dx.doi.org/10.22201/iie.18703062e.1972.sup1

JosŁ HERNÁNDEZ DELGAdILLo. Exposición Dolor y Violencia II, presentada por la Galería de Arte Edvard Munch, Reforma 489, del 10 al 22 de noviembre.

EXPosición colectiva de pinturas y grabados, realizada en beneficio de los Niños del Hospital Infantil de México, presentada por la Galería Rosano, Florencia 32, del 10 al 20 de noviembre.

Nombre de los expositores: Francisco Avila Peña, Rodolfo Aguirre Tinoco, Ignacio Aguirre, Gustavo Alanis, Ernesto Alcántara, Raúl Anguiano, Aida Arceo, Marie Avila, Alfonso Ayala, Ignacio Barrios, Ignacio M. Beteta, Alberto Ballón, Ma. Teresa Campos, Gerardo Cantú, Fernando Casas Castaños, Guillermo Ceniceros, Martha Cervantes, José Chávez Morado, Edgardo Cohlan, Jesis Contreras Peña, Agustín Cotero Ponce, Magdalcna Cortes, Erasto Cortez Juárez, Francisco Dosamantes, Alejandro Creel, Roberto Cucva del Rio, Dolores de la Barra, Carmen de la Borbolla, Eduardo Delmar, Martha de Nancy, Luis Nishizazea, Mauricio Devouk, Alicia Devouk, Alex Duval, Manuel Echauri, Vicente Gandia, Bcrtha Gómcz Palacios, Angelina Grosso, Maria Guzmán, Alicia Hawlay, Eugenia Margarita Hernández, José Hernández Delgadillo, Ignacio Hernández López, Julia López, Javier López Vázquez, Yola Loria, Leonel Maciel, Benito Messeguer, Francisco Moreno Capdevilla, Efrain Moya, Leonardo Nicrman, Martha Orozco, Trinidad Osorio, Feliciano Peña, Jorge Quiroz, Fanny Rabel, Manuel Rivera Toro, Angela Razo, Mario Reyes, Irma Rí, Yolanda Roel, Peggy Saavedra, Fernando Sabatini, Adriano Silva, Guillermo Silva Santanaria, Ana Soberón, Esteban Soto, Susana Smith, Rosa Ma. Sustaetas, Angel Trujillo, Ernesto V'arón, Roberto Velazco, Puri Yánez, Jorge Zúñiga.

guillermo terminel. Exposición presentada por la Galería de Arte Mexicano-Florencia, Florencia 35-E, el 11 de noviembre.

¿Cómo es cl hombre, allá, en su más profunda intimidad, en su región secreta? Con trazo fino, tan fino que podría parecer producto de la paciencia o dominio del oficio, cuando en realidad es fruto de la íntima verdad alucinada, Guillermo Terminel, este gran artista aparecido sin aviso, sin acta de nacimiento y sin clarines, contesta la pregunta: el hombre es un ser extraño, telúrico y apacible, suntuoso y miserable, en el que con absoluta naturalidad habitan y cohabitan los monstruos y las palomas.

Al entenderlo y, sobre todo, al expresarlo de manera sorprendente y magnífica en el idioma del ARTE, Guillermo Terminel realiza la tierna tarea de reconciliar al hombre con su secreto.

JoSEFINA VICENS

Cabe al ARTE de México enriquecerse ahora con las extrañas inquietudes de Guillermo Terminel que en fascinantes dibujos con formas corró́das por la luz o por la sombra, medita sobre la vuelta a la nada, la confusión de las especies, las fuerzas descncadenadas. Algunos de sus personajes parecen obsesiones de la angus- 
Lá ciel hombre al que I)ios puede abandonar, $y$ otros son nonstruos de visiones oníricas y apocalípticas, surgiendo también con ellos, contornos de sorprendentes flores donde cautiva una inagotable alquimia transformadom.

BERTA TARACENA

Lna infancia sin fin, que navega desde la sombra lasta el descubrimiento poético.

AnTONIO PELÁl:z

Seres de la obsesicin -blanco y negro- que transportan al espejo incandescente del fuego de la razin incomprensible. Caligrafias donde surgen vampiros, calaveras, fantasmas, hombres torturados y torturas inenarables. Todo se va consuniendo en Jlamas, en delirios y hechizos paralelos a lo fantástico de la literatura y al orden figirlo del razonamiento estrellado en el celaje de lo más muerto de lo vital: los paradigmas, las conjunciones y las disyunciones de Guillermo Terminel son fruto de: imagrinación ardicute: fiebre de la cual nacen los espectros y las pesadillas de lor actos nágicos del lonubre cotidiano: s1 misnua razón de ser es alucinación y ejmuplo señero del porder de crear a partir de las sombras y los cielis metafóricos.

Alfonso de: Neuvitiate.

ARTuro fstrada. Fxposición de pintura $y$ obra gráfica, presentada por la Gatería Iosé Ma. Velasco, INPA/SEP, Peralvillo 55, del 12 de noviembre al 5 de dicienbre.

AI.Fonso ayala. Exposición presentada por el Salón de la Plástica Mexicana, INBA/SEP, Havre $N^{\prime \prime} 7$, del 12 al 30 (ie novicmlore.

Imagen y receta. El fintor está träbajando. Colaboran con él las abejas -cerala resina de un abusto - copal- y una firma cxtranjera de colorantes. Con estos tres elementos se hace nuo solo, moldeado en vasos de cartón. Para usarlo, mutaro sobre el cuadrado de fibracel, se calienta a la llama de un soplete. El pincor trabaja, nira un apunte coloreado que le guía para realizar el cuadro que está laciendo a la cncáustica-con-fuego. Tntal las barritas gruesas de color-cera y copal, sobre el fibracel $y$ luego aplica el soplete que al fundir la cera colorida va uniendo los colores Y consigue así los tonos que quiera. La cera calentarla la untá con una espátula jequeña. Los pinceles descansan. La llama del soplete es un pincel de fuego. Ea pintor trabaja. Se pare: por el color disociándolo y asociándolo. La pinturia a la enćinstica-con-fuego, requiere sensibilitat suprema y habilidad para sor, como en este caso, un Maestro. Se pnede hablat de suntuosidad delante de estos cuadros prutados con fuego. Lat pertica del color sentida a la temperatura del soplete. Io ya he dicho que el paisaje es una creación personal. Es aquel fragmento de la inturaleza que, en un insiate, se une al pintor por afinidad, por esa simpatia que 
llamamos preferencia aunque no sea sino por unas horas. Algo de mineral con luz mojada tiene este procediniento de la encáustica, que atesora una antigüedad egipcia y griega. El pintor trabaja y veo, asombrado, que puede dibujar aplicando sabiamente el soplete. Veo cómo se escurre la cera al calentarse, derritiéndose a volumtad del artista y cómo los colores se mueven y dejan de hacerlo al enfriarse. Es un procedimiento dinámico cuando nno asocia su origen animal y vegetal y la acción del fuego en la mano del hombre y el gasto de los ojos a través del sistema nervioso. Todo un ciclo dinámico que va de la materia al espíritu.

Desde Clausell y ATL no habíamos tetrido un pintor impresionista de tantá categoría: Clausell al úleo, el Dr. ATL con sus colores y éste a la encáustica.

Me complazco en declarar mi adniracion por el maestro Alfonso Ayala.

Carlos Petilicer

Catálogo: 1. Tescutsingo (baño de Netzahualcóyotl), encáustica s/triplay 2.16 x 1.22 mts. 2. los volcanes desde Clualco, encáustica s/caoba $1.72 \times 0.72$ mits. 3 . cl Paricutin, Mich., encáustica s/caoba $1.51 \times 0.50 \mathrm{mts}$. 4. el Paricutín desde Angaunan, Mich., encánstica s/caoba 5. la laguna de Acuitlapilco y La Malinche. Tlax., encáustica s/caoba 6. Zinapécuaro, Mich., encáustica s/caoba $1.22 \times 0.61$ mis. 7. rastrojo en Chinconcuac, Texcoco, 1.22 x $0.61 \mathrm{mts}$. encáustica s/caoba 8. el Popocatépetl desde Nepantla. $0.80 \times 0.61$ nits. encáustica s/caoba 9. la Malinche desde Tlamacas, $1.22 \times 0.81$ encáustica s/caoba 10 paisaje de Tancitaro, Mich., 1.22 x $0.81 \mathrm{mts}$. encáustica s/caoba 11 . d zalle de México desde Chimalpa, Fdo. de México, $1.08 \times 0.61$ nits. encétustica s/canba 12. d valle de Mérico, 1.08 × $0.61 \mathrm{mts}$. encáustica s/caoba 13. Pátzcuaro, Nich., 1.08 x $0.61 \mathrm{mts}$. encáustica s/caba 14. Tepoztlán, Mor., 0.61 x 0.40 encáustica s/caoba 15. Chimalpa, Edo. de México 0.76 × $0.44 \mathrm{mts}$. encánstica s/caoba 16 . cl farallón del Mexicano, Jalisco, $0.50 \times 0.32 .5 \mathrm{mts}$. encáustica s/caoba 17. paisaice en Chalco, Edo. de México, $0.76 \times 0.44$ mts. encáustica s/fibracel 18 . paisaje nichoacano $N^{o} 1$ (estudio), $0.61 \times 0.40 \mathrm{mts}$. encáustica s/croba 19. paisaje michoacano $N^{o} 2$ (estudio), $0.61 \times 0.40$ nits. 20. El Popo y lil l'entorrillo, $0.66 \times 0.51$ mis. encálistica s/caoba 21. sabinos en el río Lima (Chanácuaro, Gto.), 1.52 x $0.71 \mathrm{mts}$. encálustica s/cáoba.

1:unencio castullo. Exposición de esculturas recientes, presentala por el Salón de la Plástica Mexicana, INBA/SEP., Havre $\mathbb{N}^{n} 7$, del 13 de noviembre al $1^{\circ}$ de dicienbre

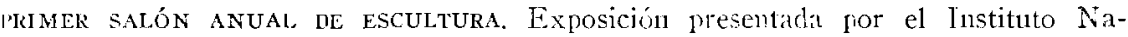
cional de Bellas Artes, Museo de Arte Moderno, Bosclue de Chapultepec, vestíbulo del edificio grande $y$ jardin izçuierdo, del 14 de noviembre al 9 de enero.

En 1962 el Instituto Nacional de Bellas Artes presentí la Primera Bienal Nacional de Fscultura. No existían entonces las actuales instalaciones del Museo de Arte Moderno en Chapultepec con sus amplios espacios verdes, sus zonas asfaultadis, sus desniveles y edificios que perniten al nuscórrafo jugar con elemcntos visuales para lacer resaltar a los ojos del público los valores artísticos, expresivos y funcionales de las obras. Las piezas de mayor tamaño quedaron instaladas entonces en la Alameda Central y las pequeñas en las Galerias de Artes Plásticas de la Ciudad de México. Enpresa insólita entonces, no fue un acto de prestidigitación 
del INBA para hacer surgir abracadabrescamente una producción escultórica de importancia. La iniciativa del organismo gubernamental no hizo más que dar solución a una postergada necesidad del arte mexicano contemporáneo: demostrar el alto nivel, las muy variadas tendencias y los caracteres particulares de la producción escultórica local. Maestros consagrados y jóvenes valores deslumbraron a los innumerables espectadores que desfilaron por veredas y prados de la Alameda Central. El conjunto despertó gran entusiasmo porque demostró de manera fehaciente que el hacer escultórico en México no se había estancado en academismos anacrónicos, que se empleaban técnicas muy diversas para solucionar concepciones estéticas muchas veces avanzadas, que los cultivadores de las formas consagradas en la antigüedad prehispánica iban más allá del remedo o el trasvasamiento, e insuflaban nueva vida a la hierática elegancia de máscaras, de bloques compactos en los que se inscriben un mínimo de signos y volúmenes, o aprehendían la cotidianidad de hoy con la dinámica esencial, subjetiva y objetiva, de la vivaz escultura doméstica de los antepasados. Con respecto estimulante se supo dar su lugar a la experimentación, a las riesgosas incursiones hacia lo desconocido, así como al trabajo concertado de la escultura con otras disciplinas, principalmente con la arquitectura.

Realizada en momentos propicios - por la dignidad de la empresa y su rápida, cierta, legítima y perdurable resonancia-- la Primera Bienal Nacional de Escultura es, en buena medida, el obligado punto de referencia de todo lo que aconteció después en exhibiciones de escultura y es, también, el antecedente que debe tomarse en cuenta ahora cuando el INBA se ha decidido por una periodicidad más frecuente, al establecer para el Museo de Arte Moderno el Salón Anual de Escultura, en el cual no habrá premiación ni tampoco jurado seleccionador. Tanto han protestado algunos grupos de artistas contra estas prácticas que bien se hubiera podido provocar una parálisis en las promociones oficiales. Hasta tanto haya un acuerdo sobre asunto tan debatido como poco clarificado, el INBA se ha decidido por las puertas abiertas. Peligroso resulta el trueque de la severa calidad por la generosa cantidad; pero la protesta de los héroes suele ser nuchas veces síntonia de fatiga. Los maestros ya han hecho lo suyo en competencias y confrontaciones. No se trata de llenar el vacío dejado por ellos con mitos o melancólicas evocaciones sino con la nueva generación. ¿Existe esa nueva generación? Como contundente respuesta baste señalar que más de la mitad de los participantes en este Primer Salón Anual de Escultura no habían estado presentes con sus obras en las cuatro Bienales Nacionales que lo han precedido y de las cuales él es heredero directo. Las ausencias son tantas y tan importantes que bien puede afirmarse que un ciclo se inicia para la escultura mexicana. Asi debe verse este Salón y no como una síntesis del verdadero estado de la escultura en México hoy, porque estarán ausentes creadores en plena actividad como Fidencio Castillo, Rosa Castillo, Germán Cueto, Helen Escobedo, Angela Gurría, Herbert Hofmann-Ysenbourg, Armando Ortega, Olivier Seguin, Anastasio Téllez, Martha Adams, Elizabeth Catlett, Estanislao Cotitreras, Francisco Marín, Lorraine Pinto, Manuel Felguérez, Pedro Cervantes, Jorge Dubón, Francisco Zúñiga, Antonio Castellanos, Juan Luis Díaz, Fernando González Cortázar, Heriberto Juárez, Jorge Tovar, Beatriz Caso, Federico Cantú, Pedro Coronel, Juan Soriano, Mathías Goeritz, Federico Canessi, Jesús Gutiérrez Martínez y otros muchos que, con más o menos años de vida, se cuentan entre quienes han configurado el actual nivel de la escultura en México. 
Más de ochenta artistas han enviado unas ciento setenta piezas de variados estilos y calidades, resueltas en técnicas tradicionales o novedosas. Junto a los finísimos ónices, mármoles y piedras mexicanas, se pueden ver obras resueltas en madera, en materiales sintéticos, en piedras reconstituidas, en planchas de acero, en chatarra o elementos prefabricados. No podía faltar - felizmente- algún aporte cinético y un poco - aunque sea tímido dentro de su simplificada belleza- de arte conceptual. También conviven aquí y ahora $-y$ es saludable que ocurrala extravagancia con valores decantados. Las disonancias alertarán a los espíritus y los inducirán a conclusiones, que son indispensables en toda etapa inicial.

Desde su renacimiento hacia la segunda y tercera décadas del siglo, la escultura contenporánea mexicana ha conocido capítulos diferenciados: indigenismo, sintetismo, clasicismo, neoclasicismo, constructivismo, un poco de cubismo, también simbolismo y surrealismo, quizás demasiado popularismo y otro tanto de hibridismo burocráticos o cortesanos. En todo este quehacer ha tenido una influencia definitiva el genio popular para las tarens de modelado, talla u organización rígida o móvil de bultos y volúmenes, donde los artesanos despliegan una inventiva funcional y fantástica a la vez, pues no hay que olvidar nunca que lo escultórico es para buena parte del pueblo mexicano un elemento de convivencia y comunicación. Téngase presente los juguetes, los objetos de culto y las cosas de uso doméstico. Y tómese en cuenta también la fuerte influencia ejercida por algunas figuras claves de la revolución escultórica posromántica. De la mixtura surgieron esculturas superiores de insospechada originalidad, que quebraron una y otra vez éste o aquel cerco dognútico. El arte monumental de relativa elocuencia cívica va siendo sustituido por una monumentalidad de articulaciones urbanas que mira al hombre nuevo, de cuya sensibilidad quiere alimentarse porque pretende intervenir en su desarrollo. La escultura para interiores se sigue cultivando en ejemplares más o menos pequeños, mas el sentido del adorno va siendo sustituido por el del medio habitable. E] escultor quiere ejercer el derecho -y lucha por ello- de modelar los ambientes donde el ser humano convive, aprende, comercia, discute, se agrupa, practica su fe religiosa o política. También están los avances tecnológicos que le dan un apabullante repertorio de posibilidades. El escultor de hoy tiene que reeducarse en el rigor de la selección porque los recursos materiales son infinitos. El sentido creador impone su señorío más allá de tecnicismos y sustancias. $Y$ para el sentido creador cuenta la conciencia de la tradición, el tráfico cultural, la articulación del artista con todos los valores que están en juego en su instante y en su sitio.

Reunir a los escultores es un buen modo de actualizar inquietudes y despertar la autocrítica.

RaQUeL TiBoL

Datos biográficos de los artustas: Jorge Alarcón Islas, nace en Pachuca, Hgo., el 25 de agosto de 1931. Luis Y. Aragón, nace en Chiluahua, Chilı, en 1931. José R. Aréchiga, nace en Jalapa, Ver., el 30 de octubre de 1931. Benjamín, nace en Acámbaro, Gto., en 1943. Egresado de la Escuela Nacional de Pintura y Escultura. Gustavo Bernal Navarro, nace en 1936, 1950-1958, estudios de huma- 
nidad y filosofía. Miguel Ángel Brenes, nace en Costa Rica el 12 de diciembre de 1943. Joan Bruckner, nace en Londres, Inglaterra, en 1921. Mario Bourguet, nace en Oaxaca, Oax., el 12 de octubre de 1937. Inicia su formación artística en el taller de su padre. Ficlencio Cabrales Ávila, nace en Tepic, Nay., el 16 de noviembre de 1905. Gales Cabrera, nace en 1929 en México, D. F. José Cabrera Hdez., nace en Fresnillo, Zac, el 28 de octubre de 1938. Alfonso Campos Quirós, nace en México, D. F., el 5 de marzo de 1943. Pilar Castañeda, nace en México, 1). F., el 24 de nayo de 1941. Felipe Castañeda, nace en Palna, Mich., el 16 de diciembre de 1933. Juan Castañedă, nace en Agunscalientes, Ags., el 20 de septiembre de 1942. Isaías Cervantes, nace en Celaya, Gto., en 1903. Ceferino Colinas, nace en Madrid, España, en dicienbre de 1902. Félix Córdova, nace en Veracruz, Ver., el 23 de nayo de 1923. Jnlián Cortés Garciá, nace el 8 de enero de 1920. Ma. Jilena Delgado, nace en Monclova, Coalı., el 5 de noviembre de 1921. Guillermiuta Diaz Barriga, nace elı Morelia, Mich., el 31 de diciembre de 1937. Sergio Díaz Zubieta, nace en México, D. F., el 14 de nuarzo de 1934. Jorge Durón Hubert, nace en México, el 13 de agosto de 1930. Augusto Escobedo, nace en México, D. F., el 22 de noviembre de 1914. Conrado Elkisch, nace en Charlottenburgo, Alemania, el 5 de septiembre de 1902. Emilio Farrera, nace en México, D). F, el 13 de junio de 1950. Armando Ferlerico, nace en la Ciudad de México, D. F. (ri 1945. José Luis Franco Arias, egresado de la Escuela Nacional de Artes P'ásticas de San Carlos en 1969. Gabriel Franco Soto, estudios de pintura y escriltura en la Escuela Nacional de Pintura y Fscultura "Lá Esmeralda" de 1055 a 1960. Amalia Franco, realiza estudios en la Escuela de Iniciación Artística $N^{9}$ 1, Taller Dominical en la Casa del Lago y clases particulares con Horacio Durán y Arturo Bustos en México, D. F. Concepción García Gónez, nace en Ialapa, Ver., el 8 de diciembre de 1039. Gelsen Gas, nace en México, 1). F., en 1933. Naomi Gassner de Siegmann, nace en los Estados Unidos en 1933. Xavier Girón de la Peña, nace en México, D. F., el 27 de abril de 1942. Frances Harvalik, nace en Duluth, Minnesota, E.U.A., en 1944. Delfina Hernández de Vargas, nace c! 1926. Víctor Jiménez López, nace en Nuevo Laredo, Tamps., el 4 de fehrero de 1044. Pal Kejenyes, nace en Hungria. Istudia en la Acarlenia de Belias Artes de Buclapest y en Beaux Arts de París. Lotlar Kestenbaun, escultor de origen alemán. José Kuri Breña, esturlia en la Escuela Nacional de Artes Plásticas de San Carlos. Frank Kyle, nace en Minneapolis, Minnesota, Estados Unidos de Norteanérica, 1940-41. María Lagunes, nace en Veracruz, Ver. En 1958, estudia en la Escuela de Bellas Artes de Verniruz. L’o Leoni, ale origen alenán, de nacionalidar brasileña, vive en México lace cinco años. Clarice Lindalıl de Hopps, nace en e! Fido. de Washingtun, E.Li.A, vive et México desde 1943. J11:1n M. Lópe\%, nice en San Luis Potosi, S.L.P., el 2 de mayo de 1906. José Lóper Castillo (Iosé Zepol), nació en San Miguel de Allencle, Gro, en 1933. Hesiquio López I.ucho, nace en Juchitán, Oax., el 5 de agosto de 1943. Ernesto Mallard, nace en Cusimaloapan, Ver, el 19 de mayo de 1932. Baltizar Martínez, nace el 6 de enero de 1938. En 1963 estudia en la Escuela Nacional de Artes Plásticas de San Carlos. Juan Enrique Mattínez Zárate, nace et1 Jalapa, Ver., en 1942. Raniro Meclina, nace el 14 de marzo de 1945 en Lázaro Cárdenas Villanueva, Zac. Tesús Méndez, nace en Clumacero, Gto, en mayo de 1942. Enrique Migucs, nace en Mevico, D. F., el 16 de febrero de 1945. Sáll Moreno Diaz, nace en San Rafael, 
Edo. de México, en 1933. Leonardo Nierman, nace en la ciudad de México en 1932. Mario Olmos Soria, 1961-1964 realiza estudios en la Escuela Superior de Inge-jería y Arquitectura IPN. Joaquín Ortega Esquivel, nace en México, D. F., el 14 de abril de 1949. Javier Padilla, nace el 5 de julio de 1948 en Múzquiz, Coah. Margarito Pardo Cid, nace en Alpoyeca, Gro., el 10 de junio de 1933. Faustino Peñaloza Martínez, nace el 15 de febrero de 1940. Humberto Peraza, nace en Mérida, Yuc., el 4 de diciembre de 1925. James Pinto, nace en Bijelinga (Bosnia). Yugoslavia en 1907. Yolanda Quijano, nace en Mérida, Yuc., en 1936. Glenna Rabasa, nace en Ft. Worth, Texas, el 17 de noviembre de 1944. Hermilo Ramírez, nace en 1934. Egresado de la Escuela Nacional de Artes Plásticas de San Carlos cn 1960. Abel Ramírez Aguilar, náce en la ciuclad de México, el 22 de mayo de 1943. Esteban Ramos Romero, nace en Oaxaca. Ma. Luisa Reid Rodríguez, nace en Zacatepec, Mor., el 18 de noviembre de 1943. Marcelo Rodi, nace en México, 1). F., el 28 de octubre de 1947. Gustavo San Germán Tosefe, nace en México, D. F., el 24 de diciembre de 1939. Leonel Santos Padilla, nace en Guadalajara, Jal., el 3 de abril de 1935. Fundador de la Escuela de Artes y Letras de Jalisco en 1955. Adriano Silva, nace en Querétino, Qro. el 16 cle junio de 1925. Franco Surigo, nace en Avola (Siracusa). Italia, el 6 de febrero de 1937. Waldemar Sjölander, nace en Gotemburgo, Suecia, en 1908. Estudió en su país de origen. Mexicano por naturalización. Ernesto Eduarclo Tamariz, ingresó a la Escuela Nacional de Bellas Artes, en 1923. Eduardo Tantariz M., nace en México, D. F., el 26 de julio de 1945. Luis Torreblanca, nació en México, D. F., el 3 de diciembre cle 1938. Tosia, nace en Vinitza, Ucrania, Rusial, mexicana por naturalización, egresada de lá Escuela Nacional de Artes Plásticas de San Carlos. Alizandro Valencis, nace en Chetımal, Quintana Roo, el 2 de julio de 1930. Adolfo Villa Conzález, Maestro de Artes Plásticas de la Universidad del Estado de México. Iaime Vivanco Mejia, egresado del Instituto de Artes Plásticas de Puebla. Charlotte Yazbek, nace en Puebla, Pue. Carol Zapati, nace en Los Angeles, Calif., el 10 te noviembre de 1938. Francisco Tcaza, nace el 5 de nctube de 1930. Fgresado de la Arademia de Rellas Artes de Rrusclas, Pélgica.

Catálueo: 1. ofronda, $29.5 \times 27 \times 13$ culs. bronce 2 fragmento, $52 \times 53 \times 27$ cuns. hronce 3. miticr, $60 \times 34 \times 1$ cuns. bronce 4. angel aburrido en carretilla, $53 \times$ $28 \times 46 \mathrm{cms}$. bronce 5. Maria de Yepachi en canion, piedra artificial, $47 \times 40 \times 43$ cms. 6. luceando, $27.5 \times 58 \times 25$ cnis. madera 7. la scmilla, $22 \times 42 \times 28 \mathrm{cms}$. madera 8. cl hombre, $66 \times 18.5 \times 13$ cms. matlera 9. módulo periódico, formica $60 \times 60$ cms. (4 piezas) 10. formus ambientales, madera con árnea, $1.00 \times 1.00$ mts. (4 piezas) 11. Moctesuma Illuicamina, bronce, $30 \times 30 \times 12 \mathrm{cms}$. 12. picdad, hronce, $25 \times 29 \times 13 \mathrm{cms}$. 13. cl politico, plástico, $150 \times 60 \times 90 \mathrm{cms}$. 14 . maiernidad, nármol, $35 \times 45 \times 38$ cms. 15. espcio, bronce, 1.00 x 1.50 mits. 16 . viajero, bronce, $33.5 \times 30 \mathrm{cms}$. 17. donsa, nadera. $93 \times 40 \mathrm{cms}$. 18 torso, lámina de acero 19. sin título, mármol 20. niño pensador, nármol, $39 \times 16 \times 28$ cms. 21. picrcicios atlćticos, núl'mol, $13 \times 11 \times 38 \mathrm{cms}$. 22. sin titulo, acrílico, $1.22 \times$ $1.24 \times 0.3 \mathrm{mts}$. 23. sin titulo, acrílico 24 . homcnaic a los jóvenes mártires del mundo. bronce, $1.00 \times .80 \times .20$ mts. 25. zcú́l es la Paz?, bronce, $1.00 \times .30 \times .20$ mts. 26. áquila, bronce, $50 \times 50 \times 20$ cms. 27. metcorn, nármol y bronce, $44 \times$ $40 \times 18$ cms. 28. composición cósmica, resina poliéster con fibra de vidrio, $5.45 \times 2.15 \times .15$ mis. 29. mestios desnuda, ónix blanco, 71 x $30 \times 25$ cnss. 30 . circunolución, fierro soldado, $62 \times 48 \times 30$ cms. 31. espectación, terracota, $33 \mathrm{x}$ $24.5 \times 34$ cms. 32. espectación, terracota, $25 \times 25 \times 28.5 \mathrm{cms}$. 33. burro cstropecando 
figura clásica, bronce, $35 \times 40 \times 20 \mathrm{cms}$. 34. afrodita y el amor, mármol, $1.80 \times 1.11$ x $1.26 \mathrm{mts}$. 35. atleta atándose una sandalia, bronce, $130 \times 85 \times 70 \mathrm{cms}$. 37 . cabeza, madera, $32 \times 14 \times 14 \mathrm{cms}$. 38. homenaje a la madre, madera, $35.5 \times 15 \times 14.5 \mathrm{cms}$. 39. el hombre hueco, madera, $71 \times 14 \times 12 \mathrm{cms}$. 40. homenajc a Pablo Casals, bronce, $73 \times 40 \times 30 \mathrm{cms}$. 41. sofisticación, bronce, $75 \times 55 \times 25 \mathrm{cms}$. 42 . rueda sobre mieda, recinto, $200 \times 125 \times 30 \mathrm{cms}$. 43. juego de triángulo, mármol, $160 \times 65 \times 10$ cnus. 44. $E-M X C 2$, bronce, $43 \times 28 \times 28$ cnis. 45 . la medusa de hoy, bronce, $62 \times 23 \times 25 \mathrm{cms}$. 46. Nosomi Maru, plástico y acero, $2.30 \times .85 \times .10$ nits. 47. cajita de mísica, madera, bronce y hierro, $1.00 \times 2.20$ ints. 48. sin título, madera, bronce y hierro, $2.40 \times 2.20 \times 1.20 \mathrm{mts}$. 49 . el héroe, ónix, $89 \times 45 \times 22 \mathrm{cms} .50$. advenimiento, ónix, $47 \times 39 \times 32 \mathrm{cms}$. 51. pegaso, ónix, $59 \times 48 \times 18 \mathrm{cms} .52$. succa, bronce, $55 \times 23 \times 25 \mathrm{cms}$. 53. Solcdad, bronce, $40 \times 17 \times 8 \mathrm{cms}$. 54 . maternidad (contemplación de lo divino), bronce, $25 \times 25 \times 15 \mathrm{cms}$. 55. pospositivo (que se pospone poner-poner un cosa después de otra), acero inoxidable $.80 \times 6.00 \times 1.00$ mts. 56. progresión (2 partes) (Acción y efecto de progresar. Progresar-hacer progresos. Progreso-movimiento hacia adelante-adelantamiento), acero inoxidable 57. torso, madera, $63 \times 30 \times 28 \mathrm{cms}$. 58. figura, bronce, $45 \times 40 \times 36 \mathrm{cms}$. 59 . continela dol pasado, madera, $1.10 \times .30 \times .18 \mathrm{mts}$. 60 . la reina madre, bronce, $40 \times 9 \times 5$ cins. 61. sublimidad, bronce, $56 \times 4 \times 4 \mathrm{cms}$. 62. al Mesias, bronce, $35 \times 4 \times 4$ cms. 63. poesia a una niña, bronce, $35 \times 14 \times 25 \mathrm{~cm}$. 64. hombre autobiográfico, bronce, $1.10 \times .62 \times .28$ mts. 65 . endriaco, bronce, $30 \times 45 \times 24 \mathrm{cms}$. 66 . mademoisclle Artand, aln1minio, $38 \times 45 \times 30 \mathrm{cms}$. 67. momento, bronce, $70 \times 13 \times 12$ cms. 68. inspiración, ónix, $30 \times 29 \times 22 \mathrm{cms}$. 69. Richtman, aluminio, $85 \times 50$ x 50 cnss. 70. Ritoide uno, fibra de vidrio, $2.85 \times 1.52 \times .87$ mts. 71 . danzante del renado, bronce, $47 \times 26 \times 11.5 \mathrm{cms}$. 72. pescador, madera, $42 \times 22 \times 22 \mathrm{cms}$. 73. impotencia, madera, $74 \times 19 \times 13 \mathrm{cms}$. 75. cl viemes me conoci, nlata, $50 \mathrm{x}$ $14.5 \times 2.5$ cins. 76 . cl niño David, bronce, $68 \times 18 \times 23.5 \mathrm{cms}$. 77 . búlho, bronce, $31 \times 15 \times 20 \mathrm{cms}$. 78. sirına, mátmol, $43 \times 100 \times 28 \mathrm{cms}$. 79. reposo, mármol, $38 \times 62 \times 37 \mathrm{cms}$. 80. mujer triste, bronce, $1.13 \times .16 \mathrm{mts}$. 81. deportistas, bronce, $1.28 \times .31 \times .28 \mathrm{mts}, 82$. abstracción 1 , bronce, $1.30 \times 80 \times 45 \mathrm{cms}$. 83 . retrato de León Felipe, bronce, $70 \times 60 \times 60$ cms. 84. el porrista, madera, $2.04 \times .59 \times .41$ mits. 85. Woodstock, bronce, $57 \times 23 \times 21$ cins. 86. hemana, madera, $57 \times 57$ × 57 cms. 87. cabesa de Don Quijote, hierro soldado, 51 x 33 x $31 \mathrm{cms}$. col. Ing. Erik Wallstern 88. bravada intitil, bronce, $39 \times 26 \times 9$ cons. 89 . composición a don Benito Juárez, madera, $1.30 \times .50 \times .40 \mathrm{mts}$. 90. familia, madera, $65 \times 20 \times$ $15 \mathrm{cms}$. 91. la pajarcra, madera, $40 \times 100 \times 20 \mathrm{cms}$. 92. labradores, bronce, $42.5 \times 31 \times 26 \mathrm{cms}$. 93. el metate, bronce, $19 \times 51 \times 14 \mathrm{cms}$. 94. bailarines, bronce, $42 \times 31 \times 14$ cms. 95. mujer sentada, terracota, $33 \times 39 \times 35$ cms. 96. naturacosas colgantes, acrílico y metal, $100 \times 100 \times 20 \mathrm{cms}$. 97. Mava, metal soldado, $1.90 \times .75 \times .50 \mathrm{mts}$, 98. flamingo, metal soldado, $192 \times 70 \times 50 \mathrm{cms}$. 90. tróbol 71, nármol, $2.41 \times .62 \times .40 \mathrm{mts}$. 100 . forna femenina, bronce, $1.00 \mathrm{x}$ $.35 \times .40 \mathrm{mts}$. 101. figura de mujer, yeso, $66 \times 99 \times 51 \mathrm{cms}$. 102 , relicie con figura, yeso, $90 \times 140 \times 10$ cms. 103 . en el sol, madera, $105 \times 28 \times 20.5 \mathrm{cms}$. 104. flor de cacto, nudera, $60 \times 15 \times 16$ cms. 105. cacto tiemo, madera, $62 \times$ $14 \times 24$ cms. 106. americana, bronce, $50 \times 11 \mathrm{cms}$. 107. filósofo, bronce, $52 \times 20$ cms. 108. tripode, terracota, $33 \times 27 \times 27 \mathrm{cms}$. 109 . figura cósmica, terracota, $42 \times 30 \times 27 \mathrm{cms}$. 110. ave del paraíso, ónix, $200 \times 21 \times 25 \mathrm{cms}$. 111. suspensión, ónix, $40 \times 91 \times 60 \mathrm{cms}$. 112. ala, ónix, $70 \times 110 \times 39.5 \mathrm{cms}$. 113. E.S.E. madera y acrílico, $34 \times 26 \times 21$ cms. 114. T.E.S., madera y acrílico, $34 \times 26 \times 21$ cnss. 115. N.C., madera y acrílico, $33 \times 61 \times 11 \mathrm{cms}$. 116. hambre, bronce, $31 \mathrm{x}$ $14 \times 13 \mathrm{cms}$. 117. dognático, bronce, $26 \times 16 \times 16 \mathrm{cms}$. 118. el brujo, piedra artificial, $74 \times 26 \times 20 \mathrm{cms}$. 119. agonia del guerrero, piedra artificial, $32 \times 27$ $\mathrm{x} 18$ cms. 120. génesis y apocalipsis, mármol y ónix, 54 x 34 x $40 \mathrm{cms} .121$. relicve, familia, repujado en cobre, $90 \times 60 \times 9 \mathrm{cms}$. 122 . animal, plástico, $60 \times 72 \times 40$ cins. 123. ajolote, piedra $23 \times 87 \times 26 \mathrm{cms}$. 124. complejo mericano, bronce, $190 \times 68 \times 60$ cms. 125. semilla, ónix, $51 \times 27 \times 31 \mathrm{cms} .126$. manos, bronce, $72 \times 36 \times 31$ cms. 127. saludos, bronce, $39 \times 15 \times 2.5$ cms. 128 . 
Icarus, bronce, $40 \times 23 \times 20$ cms. 129. castigo, bronce, $30 \times 6 \times 5$ cms. 130 . cristal de mi universo, técnica mixta, $70 \times 30 \times 30 \mathrm{cms}$. 131. la pareja, hierto solclado, $41 \times 18 \times 12 \mathrm{cms}$. 132. noble, bronce, $55 \times 24 \times 13 \mathrm{cms}$. 133. nuevo ángel de la paz, stoneware, 71 x $53 \times 20 \mathrm{cms}$. 134. cabeza de Rosi, stoneware, $50 \times 35 \times 30 \mathrm{cms}$. 135. perro $N^{Q} 2$, bronce, $17 \times 20 \times 7 \mathrm{cms}$. 136. anatomía de un loro, vidrio, $19 \times 40 \times 14$ cms. 137. mujer con niño, obsidiana, $26 \times 18 \times 11$ cms. 138. signos blancos, madera, $62 \times 31 \times 16 \mathrm{cms}$. 139. positivo negativo, madera, $42 \times 34 \times 10$ cms. $140 . M$, madera, $25 \times 21 \times 15 \mathrm{cms}$. 141. sol en expansión, chatarra, $50 \times 49 \times 14$ cms. 142. Vietnam, madera, $9 \times 18 \times 7$ cns. 143 enajenación (esquizofrenia), madera, $37 \times 31 \times 20 \mathrm{cms}$. 144. serie nuestro tiempo $N^{o} 1$, bronce, $93 \times 31 \times 14 \mathrm{cms}$. 145. seric mestro tiempo $N^{0} 2$, bronce, $113 \times$ $115 \times 42 \mathrm{cms}$. 146. predicción de la convergencia de las edades, técnica mixta, $35 \times 14 \times 9 \mathrm{cms}$. 147. en busca de la evolución perdida, técnica mixta, $33 \times 23 \times 9$ cms. 148. llorando tristeza, bronce, $30 \times 23 \times 13 \mathrm{cms}$. 149. victoria 71 , bronce, $17 \times 7 \times 3 \mathrm{~cm} s$. 150. conjunto, madera, $60 \times 60 \times 60 \mathrm{cms}$. 151. el profeta, bronce, $107 \times 21 \times 21 \mathrm{cms}$. 152. Leona Vicario, bronce, $65 \times 30 \times 20 \mathrm{cms}$. 153. adolescente, bronce, $81 \times 21 \times 21 \mathrm{cms}$. 154. construcción $I I$, bronce, $49 \times 19 \times 25$ cms. 155. ilusión esférica, bronce, $49 \times 43 \times 32 \mathrm{cms}$. 156. acueducto, bronce, $53 \times 39 \times 12 \mathrm{cms}$. 157. águila, piedra y hierro, $1.50 \times 60 \times 20 \mathrm{cms}$. 158. mujer con arpa, piedra, $96.5 \times 45 \times 88 \mathrm{cms}$. 159. unidad, ónix, $45 \times 40 \times 43.5 \mathrm{cms} .160$. soñar y dormir, bronce, $52 \times 42 \times 38 \mathrm{cms}$. 161. naturaleza en vivo $N^{g} 3$, chatarra y relicve, $87 \times 176 \times 24$ cms. 162 . don Quijote $N^{Q} 1$, chatarra y relieve, $1.40 \times$ $.50 \times 1.13$ mts. 163. don Quijote $N^{0} 2$, chatarra y relieve, $115 \times 32 \times 30 \mathrm{cms}$ 164. el flautista, cantera, $106 \times 62 \times 60 \mathrm{cms}$. 165. niño otomí llora porque se muer su venado, cantera, $61 \times 32 \times 28 \mathrm{cms}$. 166 . el ojo que todo lo ve, aluminio, $50 \times 30 \times 15 \mathrm{cms}$. 167. pájaro al espacio, hierro y aluminio, $130 \times 25 \times 50 \mathrm{cms}$. 168. adagio, bronce, $3.00 \times 1.80 \mathrm{cms}$. 169. la pareja IV, 1971, bronce, $52 \times 46$ cmss. 170. Madona, 1971, bronce, $60 \times 24 \mathrm{cms}$. 171. parte de una ciudad, 1970 , madera con oro de hoja, 90 × 90 × 50 cms.

MATiIiAs GoeRtTz. Exposición de obras realizadas entre 1950 y 1970, presentada por la Galería Mer-Kup, Molière $\mathrm{N}^{0} 328-\mathrm{C}$, el 15 de noviembre.

helen bickham. Exposición de obras, presentada por las Galerías C.D.I., Centro Deportivo Israelita, Boulevard Manuel Avila Camacho, No 620, el 16 de noviembre.

arte irracional. Exposición colectiva, presentada por la Galería Gandhi, Miguel Angel de Quevedo 128, el 19 de noviembre.

Nombre de los expositores: Aceves, Antragne, Basurto, Bremer, Carrington, Durán, A. Durán Vázquez, Xavier Esqueda, Friedeberg, García Sácnz, Glass, Horna, Leportier, McGrath, Ocampo, Sicner, Somolinos, Stárez, Toledo, Weiss.

RODOLFO REYes tReviño. Exposición de cuadros, óleos, acrílicos y dibujos presentada por la Galería Rosano, Florencia 32, del 22 de noviembre al 4 de diciembre.

Llega de Monterrey, su adiestramiento en el arte de la pintura se lo debe a sí mismo, es un legítimo autodidacta con todas las dificultades y ventajas que ofrece esta vía.

Sin duda alguna, ha entrevisto ciertas etapas de Kandinsky, o el diseño de Klee, el caso es que ha escogido para expresarse plásticamente algo que se asemeja a dichas maneras; rasgos puestos de manera casi automática, para definir la 
presencia del espacio y que adquieren calidades como de expresión hecha con jresteza para quedar como pivote de realizaciones de más enjundia. En realidad recuerda también obras de Mathieu. Deja correr el pincel de preferencia en directrices curvas, que se desarrollan y forma11 diseños caprichosos fraguados de improviso en el fuero interno del artista.

Su pintura parece expresada a base de signos bastante ricos de un alfabeto especial que está relacionado casi todo con el mundo biológico, preferentemente el vegetal.

Estos apuntes rápidos no se vertebran, deliberadamente, a una atmósfera que no sólo es una continuación de los colores y el carácter de las formas sino que llegan a identificarse con valores tonales a todo el tema. Un reflejo de su carácter es que no tiene inhibiciones en su animada paleta. Tal vez haya algún ejemplo en que deja en demasiada libertad sis derroche de tintas vivas, casi acres.

En las sugerencias lineales de las formas más finas, más concretas, alguna vez se reconoce la silueta de un papagayo o una ave del paraíso. Su pincelada es resuelta como si existiera un bosquejo previo. Considero estas obras comentadas cono dibujos realzados por el color. Cuando más se aproxima a una calidad más esencialmente pictórica es en uno de sus acertados paisajes. Tiene simplificación de mucho gusto, tanto en manojos de flores, como en el cuerpo humano, semejándolo realmente a algo frutal o floral.

Lo nás destacado en su serie actual de acrílicos es la forma de manejar una rica simbología y el aprovechamiento de la forma.

Jorge J. Cresto de la Serna

LIBROS CIENTÍfICOS Y récNICOS. Exposición presentada por la Universidad Nacional Autónoma de México, Embajada de Francia en México, Asociación para la Difusión del Libro Científico y Técnico Francés, Museo Universitario de Ciencias y Arte, del 23 de noviembre al 3 de diciembre.

I'UBLICACIONES francesas. Exposición presentada por la Universidad Nacional Autónoma de México, Embajada de Francia en México, Unión Nacional de Editores y Exportadores de Publicaciones Francesas, Museo Universitario de Ciencias y Arte, del 23 de noviembre al 3 de diciembre.

TRINidan osorio. Exposición presentada por la Galería Plástica de México, Londres 139, del 24 de noviembre al 10 de diciembre.

Litografías. Exposición presentada por el Instituto Nacional de Bellas Artes, Palacio de Bellas Artes, Sala Internacional, el 24 de noviembre.

AUGUSTo ropin. Exposición presentada por el Instituto Nacional de Bellas Artes, Embajada de Francia, Museo de Arte Moderno, Bosque de Chapultepec, Galería de Exposiciones Temporales, Planta Alta, el 25 de noviembre.

E1 12 de noviembre de 1840, señala en la historia del arte, el nacimiento del más grande escultor francés del siglo xix: Augusto Rodin. Feliz coincidencia que, en este otro noviembre y a más de una centuria, México rinda tributo al genio del 
artista, en esta América que ya un día le consagró su admiración y reconocimiento.

La exposición que el gobierno de Francia envía a nuestro país en un gesto de recíproca amistad, nos concede el privilegio de contemplar las obras que llenaron toda una época y que serán siempre: ejemplos de una pasión por expresar el sentimiento a través de la forma.

Este conjunto de esculturas del mastro, que el Instituto Nacional de Bellas Artes acoge con emoción en su Museo de Arte Moderno, a pesar de no ser sino una parte de su gran producción, no es por ello menos inportante, ya que cada obra es en si misma como él se propuso: "vida que surge de un centro, que germina y se expande de dentro a fuera". Palabras de su testamento estético publicadas en el arte de Rodin; este libro que hoy quisiéramos volver a abrir, para recorrer con los ojos y con el corazón su extraordinaria lección de humanidad.

Hace apenas unos días, el 17 de noviembre se cumplió el quincuagésimю cuarto aniversario de la muerte del maestro, acaecida en Meudon en 1917. Rodin fue un luchador incansable contra la mediocridad y los prejuicios de su tiempo, y tuvo la voluntad inquebrantable para defender sus ideas hasta alcanzar el triunfo sin envanecimiento. Más bien, para realizar el acto supremo de la generosidad del artista, ligando su obra al Estado francés. Parte de este legado es el que hoy contenplanos, y es herencia que se entrega por igual a la humanidad entera.

Miguel Bueno

Si en la Exposición que presentamos en la planta baja de la Galería de Exposiciones Temporales del 23 de septiembre al 23 de octubre de 1969 titulada "Dibujos de escultores, de Rodin a nuestros días", $y$ en la cual se presentaron algunas obras de él, pudimos comprobar que despertaron gran inquietud y admiración entre el público que nos visitó, pero no quedando satisfecha, hubo la promesa de la Sra. Cécile Goldscheider, Conservadora del Museo Rodin de París, de que haría lo inposible por enviarnos en fecha próxima una importante exposición de esculturas y dibujos del artista cuyo Museo ella dirige.

Aun cuando será imposible que podamos disfrutar de sus famosas obras como "El Beso" un mármol realizado en 1886, "El Eterno Ídolo" de 1889 (ambas obras (le ternura amorosa increíble), sí vendrán obras tan importantes como "El Pensador", “La Meditación", "La desesperación”, "El Hijo Pródigo" y varios estudios "De los Burgueses de Calais", retratos tan importantes como el de "Balzac con abrigo", "De Maclame Rodin" entre otras muchas de las 55 obras que presentaremos y los 30 dibujos y acuarelas.

Incluir esta exposición en La Semana de la Cultura de Francia en México, es motivo para que nos sintamos muy satisfechos y nos consideremos obligados a agradecer a la Sra. Cécile Goldscheider el cumplimiento de su promesa y al Gobierno Francés a través de sus representantes Diplomáticos en esta ciuclad, el haberla incluido y enviado al Museo de Arte Moderno esta magnifica exposición para la citada Semana de la Cultura de Francia en México.

Carmen Barreda, Directora 
Dutos biográficos del artista: Augusto Rodin, nació en París, el mes de noviembre de 1840. Entró a la Escuela de dibujo y matemáticas, calle de l'École de Médecine, en el año de 1854. En 1857, fracasó en la Escuela de Bellas Artes.

Catálogo: 1. mignon, 1870 , bronce $40 \times 28 \times 20$, retrato de Rose Beuret 2. la edad de bronce (L'âge d'airain), $1876-1877$ bronce $105 \times 38 \times 303$. el hombre que camina, 1878, bronce $84 \times 28 \times 574$, el pensador, 1880 , bronce $69 \times 40 \times 50$ 5. Eva, 1881, bronce, $70 \times 25 \times 26$ 6. estudio para Adán, 1881, bronce, $26 \times 8 \times 10$ 7. cariátide en piedra, 1881 , bronce $44 \times 32 \times 32$. gran torso de hombre (1882. 1900) O Marsyas, bronce, $105 \times 60 \times 409$. soy bella, 1882 , bronce $75 \times 40 \times 30$ 10. estudio para una condenada, 1884 , bronce $21 \times 37 \times 2511$. la meditación, 1885 bronce, $60 \times 28.5 \times 28.5$ 12. la nártir, 1885 , bronce, $13 \times 70 \times 40.5$ 13. la fuga, hacia 1885 , bronce, $22.5 \times 10.5 \times 16$ 14. anor fugaz, 1885 , bronce, $45 \times 38 \times 17$ 15. el hijo pródigo, 1888 , bronce, $140 \times 106 \times 70$ 16. desesperación, 1890, bronce, $34 \times 26 \times 30$ 17. estudio para Eustaquio de Saint-Pièrre, 1885 , bronce, $98 \times 33 \times 42$ 18. estudio para Pedro de Wiessant, 1885, bronce, $61 \times 36 \times 2219$. Juana D'Airc, 1866 , bronce, $46 \times 13 \times 16$ 20. Pedro de Wiessant, 1886 , bronce, $46 \times 13 \times 16$ 21. Jian de Fiennes, 1886, bronce, 46 x $14 \times 28$ 22. Andrieu d'Andres, 1886, $46 \times 19 \times 21$ 23. Eustaquio de Saint-Pièrre, 1886, bronce $46 \times 14 \times 2625$. Estudio de desnudo para Balac $C$, bronce $75 \times 30 \times 3726$. estudio de desmudo para Balzac F, bronce, $96 \times 40 \times 36$ 27. Balzac con levita, bronce, $60 \times 24 \times 30$ 28. máscara sonriente de Balzac, bronce, $18 \times 16 \times 1529$. cabeza monumental de Balsac, bronce, $49 \times 49 \times 3530$. Julio Dalon, 1883 , bronce $52 \times 58 \times 2231$. señora Rodin, 1890, bronce, $27 \times 17 \times 16$ 32. Carlos Baudelaire, 1898, bronce, $20 \times 19 \times 23$ 33. la Francia, 1904 , bronce, $48 \times 50 \times 4034$. la eterna primavera, 1884 , bronce, $65 \times 50 \times 4235$. el minotauro, 1886 , bronce, $34 \times 25 \times 2536$. $V_{\text {chns, }} 1888$, bronce $58 \times 14 \times 16$ 37. las bendiciones, 1894 , bronce, $65 \times 50 \times 50$ 38. estudio de mijer sentada, 1889 , bronce, $51 \times 36 \times 2339$. torso sentado, hacia 1889 , bronce, $43 \times 26 \times 2840$. la tierra, bronce, $19 \times 46.5 \times 2741$. el atleta, 1903 , bronce, $40 \times 29 \times 25$ 42. la centanro, 1889 , bronce, $46 \times 50 \times 19$ 43. mano crispada con figura implorante, hacia 1886 , bronce, $45.5 \times 32 \times 27.544$. mano, bronce, $34 \times 25 \times 24$ 45. mano, bronce, $28 \times 23 \times 25$ 46. gran mano izquierda, bronce, $30 \times 14 \times 18$ 47. la catcdral, bronce, $64 \times 34 \times 32$ 48. figura volante, 1890 , bronce, $21.5 \times 39 \times 1749$. estudio para Iris, mensajera de los dioses, bronce, $50 \times 60 \times 2550$. movimiento de danza $A$, bronce, $72 \times 33 \times 3351$. movimiento de danza $D$, bronce, $33 \times 9 \times 10$ 52. movimiento de danza $E$, bronce, $36 \times 10 \times 20$ 53. movimiento de danza $F$, bronce, $18 \times 27 \times 1454$. movimiento de danza $I$, bronce, $14 \times 24 \times 7$ 55. Pas-de-deux $B$, bronce, $31 \times 18 \times 1456$. caballero (jinete), hacia 1880 , lápiz y aguada, 13.2 x 19 57. hombre sentado de perfil, hacia 1885 , tinta y lápiz, $18 \times 11$ estudio para La Puerta del Infierno 58 . hombre de pie de frente, hacia 1885, sepia y lápiz 19.5 x 15 59. mujer recostada, lracia 1900 , lápiz esfumado $19.5 \times 30.5$ 60. Toufle, hacia 1900 , lápiz $30.5 \times 19.8$ 61. hombre en cuclillas, hacia 1910 , lápiz, $36 \times 2362$. mujer sentada, hacia 1910 , lápiz, $31 \times 20$ 63. retrato de mujer, hacia 1905, lápiz $18 \times 19.264$ estudio de movimiento, hacia 1905 , lápiz, 31 × 20 65. mujer quitándose el vestido, lápiz, $31 \times 20$ 66. mujer arrodillada, hacia 1905, lápiz, 31 × 2067 . mujer del velo largo, hacia 1905 , lápiz, 30.5 x 2068 . mujer recostada, hacia 1905 , lápiz, 31 x 20 69. mujer desvistióndose, hacia 1905, lápiz, $31.2 \times 2070$. acróbata, visto de espalda, hacia 1900, lápiz, 22.5 x 18.571 . desmudo femenino, visto de espalda, hacia $1905,33 \times 2572$. el gato del cojin rojo, hacia $1906,21.5 \times 3273$, el invierno llegó, hacia 1905, $25 \times 32.5$ 74. la desposada, hacia $1905,32.5 \times 24.5$ 75. mujer sentada, hacia $1905,32 \times 2576$. el peinado, hacia $1905,32.5 \times 2577$. mujer de pie, hacia 1905, $32.5 \times 24.5$ 78. mujer sentada adormecida, hacia 1908 , $32.5 \times 25$ 79. bailarina, brazos levantados, hacia $1904,32.5 \times 2580$. el vestido amarillo, hacia $1904,32.5 \times 2581$. camboyana, $1906,31 \times 2082$. bailarina camboyana de perfil izquierdo, $1906,31.5 \times 24.5$ 83. bailarina camboyana de frente, 
DOI: http://dx.doi.org/10.22201/iie.18703062e.1972.sup1

$1906,30 \times 20$ 84. bailarina camboyana de frente, $1906,32 \times 24.585$. bailarina camboyana de frente, $1906,31 \times 20.3$

exposictón del, taller de gráfica infantil. Presentada por el Museo de las Culturas, INAH/SEP., Moneda 13, el 27 de noviembre.

exposición, tercer ciclo de talleres sabatinos. Presentada por el Museo de las Culruras, 1NAH/SEP., Moneda 13 , el 27 de noviembre.

Esta exposición será de cerámica, esmaltes y gobelinos.

ARTE FANTÁsTiCo y SURREALista de méxiCO. Exjosición presentada por el Instituto Nacional de Bellas Artes, Museo de Arte Moderno, Bosque de Chapultepec, Galería cle Exposiciones Temporales, Planta baja, salas derecha e izquierda, el 29 de noviembre.

E1 surrealismo es uno de los frutos de nuestra época y no es invulnerable al ticmpo, pero, asimismo, la época está bañada por la luz surrealista y su vegetación de llamas y piedras preciosas ha cubierto todo su cuerpo. $Y$ no es fácil que esas lijosas cicitrices desaparezcan sin que desaparezca la época misma.

Octavio Paz

Nombre de los expositores: Silvio Aguilcra, Anita Bucherer, Federico Cantú, Leonora Carrington, José Horna, Juan Luis Diaz, Xavier Esqueda, Pedro Fricdeberg. José García Ocejo, Gelsen Gas, Alan Glass, José Horna, Kati Horna, Frida Fahlo, Agustin Lazo, Manuel Montiel Blancas, Gustazo Montoya, Wolfgang Paalen, Juan O'Gorman, Julio Ruelas, Antonio Ruis, James Sicner, Jan Somolinos, Brigitte Tichenor, Francisco Toledo, Remedios Varo.

Catálogo: 1. crimen en el mommento a la saliduría, 1970, técnica mixta sobre fibracel, 31 x $47 \mathrm{cms}$. col. Silvio Aguilera 2. palabras, 1970, técnica mixta sobre tela, $26 \times 19.5 \mathrm{cms}$. col. Silvio Aguilera 3. crimen a la vuelta de la esquina, 1970, acrílico s/tela, $28.5 \times 23 \mathrm{cms}$. col. Silvio Aguilera 4. el romanticismo de Julin lernc, 1971, técnica mixta s/fibracel, $27.8 \times 22.6 \mathrm{cms}$. col. Silvio Aguilera 5. una vez más, 1970, acrílico s/fibracel, $29.5 \times 25.5 \mathrm{cms}$. col. Silvio Aguilera 6. monumento al samurai desconocido, 1971, acrílico s/fibracel, $31 \times 47 \mathrm{cms}$. col. Silvio Aguilera 7. quietud silenciosa, 1970, acrílico s/fibracel, 41 x $62 \mathrm{cms}$. col. Silvio Aguilera 8. monumento al héroe nacional, 1970 , acrílico s/masonite, $62 \mathrm{x}$ $41 \mathrm{cms}$. col. Silvio Aguilera 9. Circe, dibujo a lápiz, 44 × $29 \mathrm{cms}$. col. Galería Arvil 10. el rey Lear y su bufón, dibujo a lápiz, 35 x $30 \mathrm{cms}$. col. Galeria Arvil 11. el Nigromante, dibujo a lápiz, $50 \times 32 \mathrm{cms}$. col. Galería Arvil 12. la amenaza, dibujo a lápiz, 50 × $44.5 \mathrm{cms}$. col. M. D. de Ugarte 13. el enigma, dibujo a lápiz, $48 \times 34 \mathrm{cms}$. col. M. D. de Ugarte 14. hécate y sus perros, dibujo a lápiz, $59 \mathrm{x}$ $42 \mathrm{cms}$. col. Evangelina Elizondo de Moheno 15. el candado, técnica mixta, $31 \times 20 \mathrm{cms}$. col. Enrique Anhalt y Sra. 16. espejo que refleja el carácter, técnica mixta, $20 \times 20 \mathrm{cms}$. col. Salomón Birman 17. los olvidados, técnica mixta, 20 × $30 \mathrm{cms}$. col. Salomón Birman 18. las flores del mal, técnica mixta, $20 \times 30$ cms. col. Salomón Birman 19. Los patinadores, técnica mixta, $21.5 \times 21.5 \mathrm{cms}$. col. Guillermo Morgadant 20. martirio, técnica nixta, $27 \times 27 \mathrm{cms}$. col. Manuel Ávila Camacho 21. la colina de la horca, técnica mixta, 34 x $47 \mathrm{cms}$. col. Álvaro 
González Mariscal 22. sin titulo, técnica mixta, col. Ronald Thome 23. sin titulo, técnica mixta, col. Ronald Thome 24. sin título, técnica mixta, col. Ronald Thome 25. mijer, óleo, $25 \times 25$ cms. col. Alfonso de Neuvillate 26. Ixtapan, óleo, $90 \times 100 \mathrm{cms}$. col. Enrique Anhalt y Sra. 27. guerrero cuaternario, 1963, técnica mixta, 41 × 34 cms. col. Evaristo Arnus 28. animales fantásticos, 1963 , técnica mixta, $34 \times 42 \mathrm{cms}$. col. Evaristo Arnus 29. naturale $\approx a$ mueria, óleo, $00 \times 35 \mathrm{cms}$. col. Marcelo Javeily y Sra. 30. los caballeros cuatropićs, escenocrafía para "Penélope", crayón, 40 × $52 \mathrm{cms}$. col. Antonio Ojeda 31. diseño de trajes, para la obra "Penélope" (1), acuarela, col. León Davidoff y Sra. 32. diseño de trajes para la obra "Penélope" (2), acuarela, col. León Davidoff y Sra. 33. discño de trajcs, para la obra "Penélope" (3), acuarela, col. León Davidoff y Sra. 34. la Clirvsopcia de Maria de Jesús, 1964, óleo s/tela, $92 \times 153 \mathrm{ems}$. col. joli Klcin y Sra. 35. Alchimia Avium, ólco s/madera, $89 \times 25 \mathrm{cms}$. col. Robert V. T.erner 36. cuna, pintura al óleo (Carrington), talla et madera (Horna), col. Katy Horna, véase Horna y Carrington 37. ventanas de Paris, madera y vilitio, $175 \times 75 \times 75$ cms. col. Marcelo Javelly y Sra. 38. granadas, 1964, óleo $.38 \times 43$ cms. col. Evaristo Arnus 39 . pera y cubos, óleo, $34 \times 28.5$ cms. col. Clementina Díaz y de Ovando 40 . naranja, óleo, 51 x $40 \mathrm{cms}$. col. Clcmentina Díaz y de Ovando 41. Ios trabajos de Hércules, ólco, 70 x $90 \mathrm{cms}$. col. del antor 42 . inclancolia, óleo, $75 \times 100$ cnis. col. del autor 43. nostalgia, 1971, óleo, $60 \times 80$ cms. col. del antor 44. la discoteca de Luis XIV, técnica mixta, $100 \times 75$ cnis. col. Jean Louis Sonnery 45. la mano izquierda del Virrey Gumersindo Sirloin, 1968, técnica nixta, $37 \times 37 \mathrm{cms}$. col. León Voigt 46. sanatorio para tehuanas, técnica mixta, $100 \times 74 \mathrm{cms}$. col. José Castelló 47. picnic matemático, técnica mixta, 50 × 37 cms. col. Rogerio Azcárraga y Sra. 48. escenografía para un inallet auténticamente constipado con música de Gabriel D'Anunsio, técnica nixta, 50 x 37 cms. col. Rogerio Azcárraga y Sra. 49. construcciones oviparas, técnica mixta, $76.5 \times 100 \mathrm{cms}$. col. Antonio Sonza 50. fácil obstrucción, técnica mixta sobre madera, $77 \times 77$ cms. col. Joaquín Cortina y Sra. 51. los elefantes, técnica mixta s/madera, col. Robert W. Lerner 52. reloj, talla en madera, col. Enrique Anlalt y Sra. 53. escultura, talla en madera, col. Rogerio Azcárraga y Sra. 54. espejo, talla el madera, col. Tda Rodríguez de Goeritz 55. mesa desayuno para anco personas, técnica mixta, $26 \times 51 \times 40 \mathrm{cms}$. col. Antonio Sotza 56 . las llavess del templo número uno, técnica mixta, 67 x $50 \mathrm{cms}$. col. Eli Klein y Sra. 57. las llawes dol templo nimcro dos, técnica mixta, $60 \times 90 \mathrm{cms}$. col. Elsa Pratts 58. salud, técnica mixtil, $40 \times 50 \mathrm{cms}$. col. Alfredo Umansky 59. sociedad anónima, tinta, 30 × 32 cns. col. José García Ocejo y Sra. 60. The British Papillon, dibujo a la cera, 45 x $55 \mathrm{cms}$. col. Iosé García Ocejo y Sra. 61. autorretrato, técnica mixta, $45 \times 66 \mathrm{cms}$. col. José García Ocejo y Sra. 62. autorrctrato sin liscs, técnica mixta sobre pergamino, 11 x $20 \mathrm{cms}$. col. José García Ocejo y Sra. 63. la mecánica de Boucher, 1971, óleo sobre tela, 100 x $100 \mathrm{cms}$. col. Gelsen Gas 64. Yoconda Yemima, óleo s/madera, 90 × $90 \mathrm{cms}$. col. Gelsen Gas 65. díptico sin título, técnica mixta, col. Enrique Anhalt y Sra. 66. sin título, acuarela, $70 \times 55$ cms. col. José García Ocejo y Sra. 67. hada, ensamblaje, $62.5 \times 36 \times 13.5$ cns. col. Antonio Souza 68. relicario, ensamblaje, $65 \times 63 \times 27$ cms. col. Antonio Sonza 69. panal, cnsamblaje, $45 \times 46 \times 10 \mathrm{cms}$. col. Antonio Souza 70. huevo, col. Alfonso de Neuvillate 71. dibujo, técnica mixta, $20 \mathrm{x}$ $30 \mathrm{cms}$. col. Alfonso de Neuvillate 72 . tauro, talla en madera, $43 \times 135 \mathrm{cms}$. col. Marcelo Javelly y Sra. 73. mujer araĩa, talla en madera, 120 x $40 \mathrm{cms}$. col. Marcelo Javelly y Sra. 74. mujer pájaro, talla en madera, col. León Davidofj y Sra. 75. paragnos, escultura en madera, $142 \mathrm{cms}$. alto, col. Kati Horna 76. cuna, talla en madera (Horna), pintura al óleo (Carrington) col. Kati Horna, véase Carrington y Horna 77. salisburia, técnica nixta, $33 \times 12 \mathrm{cms}$. col. Marcelo Javelly y Sra. 78. albre cielo abre, técnica mixta, 35 × $15 \times 30 \mathrm{cms}$. col. Marcelo Javelly y Sra. 79. compás, cnsamblaje, $26 \mathrm{cms}$. col. Antonio Souza 80. tintero, objeto, 11 cms. alto, col. Antonio Souza 81. candclabro, objeto, 6 cms. alto, col. Ántonio Souza 82. las dos Fridas 1939, óleo, $172 \times 172 \mathrm{cms}$. col. INBA, Musco de Arte Moderno 83, $13.5 \quad x \quad 21.7$ cms. $84.13 .8 \quad x \quad 22.6$ 
$85.13 .5 \times 23 \mathrm{cms} .86 .15 \times 23.2 \mathrm{cms} .87 .15 .8 \times 22.5 \mathrm{cms} .88 .15 .7 \times 22 \mathrm{cmss} .89$. $15.6 \times 22.5 \mathrm{cms} .90 .15 .6 \times 22.2 \mathrm{cms} .91 .16 .4 \times 22.8 \mathrm{cms} .92 .16 .3 \times 22.1 \mathrm{cms}$. 93. $20.4 \times 21.2 \mathrm{cms}$. 94. $15.6 \times 23.1 \mathrm{cms}$. $95.21 .8 \times 16.3 \mathrm{cms} .96 .20 .8 \times 27.7 \mathrm{cms}$. 97. $19 \times 27.6 \mathrm{cms}$. 98. $23 \times 30.2 \mathrm{cms}$. 99. $24.5 \times 29.3 \mathrm{cms}$. col. Arq. Joaquín García Lazo (del número 83 al 99, son montajes de grabados) 100. camino, óleo, 43 x 62 cms. col. Ida Rodríguez de Goertiz 10l. valle de la luna, 1970, óleo, $61 \times 76 \mathrm{cms}$. col. de la Galería Plástica de México 102. la mariposa, óleo, col. Isabel Marín de Paalen 103. Oiseau Mouche, 1938, óleo, 24 x 33 cms. col. Manuel Macías 104. Le genie de l'Espece, pistola, ensamblaje, col. Isabel Marín de Paalen 105. los sucños de Morfeo, óleo, 22.5 x $17 \mathrm{cms}$. col. Enrique Anhalt y Sra. 106. la domadora, 1897, óleo col. Archibaldo Burns 107. la entrada de don Jesús Luján a la Revista Moderna 1904, óleo, col. Archibaldo Burns 108. la bclla Otero 1906, óleo $12 \times 30 \mathrm{~cm}$ s. col. Marcelo Javelly y Sra. 109. Vivac de barajas, óleo s/lela, 38 x $50 \mathrm{cms}$. col. Marcela Ruiz de León 110. número diez, collage y óleo, 39 x $39 \mathrm{cms}$. col. Anne M. de Miller 111. león rojo, collage y óleo, 34 x 24 cms. col. Anne M. de Miller 112. temo oriental, collage y óleo, 21 x 35 cns. col. Anne M. de Miller 113. techo bizantino, collage y óleo, 38 x 38 cms. col. Anne M. de Miller 114. black and white 1965 , collage y óleo, 40.5 x $32.5 \mathrm{~cm}$ s. col. Eli Klein y Sra. 115. collage número vcinte, 1970 , collage y óleo, $40 \times 60 \mathrm{cms}$. col. Galería Arvil 116. collage número veintidós, 1970 , collage y óleo, 40 x $40 \mathrm{cms}$. col. Galería Arvil 117. collage númer veinticinco 1970 , collage y óleo, $48 \times 70 \mathrm{cms}$. col. Galería Arvil 118. Columarpa, tinta s/papel, $22 \times 28 \mathrm{cms}$. col. Jan Somolinos 119. envase vacío, tinta sobre papel, $22 \times 28$ cms. col. Jan Somolinos 121 . retrato del actor Luis Miranda, técnica mixta $30 \times 40$ cms. (ovalado) col. particular 122. un saludo al piblico, ensamblaje, $30 \times 50$ cms. col. Jan Somolinos 123. asfixia, ensamblaje, col. Jan Somolinos 124. peregrinos, óleo $35 \times 35 \mathrm{cms}$. col Enrique Anhalt y Sra. 125. están abrazados, óleo, col. Carlos Riveroll 126. el pescador, 1967, óleo $30 \times 20 \mathrm{cms}$. col. Antonio Ojeda 127. aguas tarascas, óleo $30 \times 50$ c.ms. col. Jean Lolis Sonnery 128. marina, óleo, 26 × 39 cms. col. León Voigt 129. nana, óleo, 13 x $13 \mathrm{cms}$. col León Voigt 130 . bobo listo, óleo, 22 × $10 \mathrm{cms}$. col. León Voigt 131. pasa pasa, óleo, $38 \times 23 \mathrm{cms}$. col. León Voigt 132, los pecados venales, óleo, $7 \times 15 \mathrm{cms}$. col. Alejandro Anhalt 133. personajes, acuarela, $24 \times 33$ cms. col. Enrique Anhalt y Sra. 134. la jaiba, 1968, acrílico, $47 \times 67 \mathrm{cms}$. vol Evaristo Arnus 135. paisaje, acuarela gouache S/papel, 70 x 50 cns. col. Robert W. Lerner 136. retrato de Pilar y Clara, 1957, óleo 93 × $60 \mathrm{cms}$. col. Evaristo Arnus 137. personaje, 1961, óleo, 58.5 x 39.5 cms. col. Marcelo Javelly y Sra. 138. Los caminos tortuosos, 1958, técnica mixta s/cartón, 47 x 27.5 cms. col. Jaime García Terrés y Sra. 139. retrato del doctor Ignacio Chávez, 1957, ólco, 113 x $81 \mathrm{cms}$. col. Ignacio Chávez 140. lcs mures, 1958, técnica mixta s/papel, 50 x $32 \mathrm{cms}$. col. Henrique González Casanova y Sra. 141. el alquimista o la cimcia inútil, 1958, óleo, $105 \times 54$ cms. col. Walter Gruen 142. mimetismo, 1960, óleo, 47 x $49 \mathrm{cms}$. col. Walter Gruen 143. mujer saliendo del psicoanalista, 1961, óleo, $71 \times 41 \mathrm{cms}$. col. Walter Gruen 144. fonómeno de ingravidad 1963, óleo, 75 x $50 \mathrm{cms}$. col. Walter Gruen 145. trasinundo, 1955, óleo, $43.5 \times 55 \mathrm{cms}$. col. Walter Gruen 146. visita al cirujano plástico, óleo, $35 \times 70 \mathrm{cms}$. col. Jaine Asch y Sra. 147. plato, técnica mixta, col. Henrique González Casanova y Sra.

Feliciano béjar. Exposición presentala por la Galería Arvil, Hamburgo 241, del 29 de noviembre al 18 de diciembre.

Feliciano Béjar, entre nago y artesano, entre alquimista y obrero, entre matemático y visionario, entre viejo sabio y niño que juega, entre pintor y escultor, hace varios años que nos viene alegrando con sus juguetes mágicos, con sus esculturas que encierran en formas rigurosas la centelleante sorpresa de los colores, 
con sus magiscopios. Ilace varios años también que los lleva por el mundo, cosechando flores.

Desde 1948, cuando hizo en Nueva York su primera exposición individual de pintura, Feliciano Béjar viaja incansablemente con su obri.. El año pasado los magiscopios brillaron en la Grosvenor Gallery de Londres; en estos días está por terminar una exposición en la Circle Gallery de Nueva Or]eáns.

Pero el último viaje de Feliciano Béjar a Europa significó algo más: grandes fábricas de cristal y porcelana lo habían llamado, y le pidieron diseños para ser realizados en sus materiales preciosos. Tendremos, pues, porcelanas de Spode - csas de tan blanca y tersa blancura- con dibujos en relieve de Feliciano; tendremos límpidos cristales Barthmann en prismas y esferas de Feliciano.

La exposición de hoy es una anticipación y un reflejo de estas nuevas expresiones: los veinticinco grabados son los que servirán de modelo para las porcelamas; algunos de los objetos en plástico (ese material largamente elaborado y enriquecido por el artista), serán reproducidos en cristal. La Carborundum Company le pide a Béjar una serie de esculturas y un "múltiple" para el 1972.

Hay en los magiscopios de hoy reminiscencias de astrolabios, nostalgia de viejos relojes y planetarios renncentistas. Desde Galileo, las lentes y los astros tienen mucho que comunicarse. Y la incorporación de lentes en los magiscopios -lentcs construidos por el mismo artista- es uno de los elementos que determinan su riqueza visual.

Hay en los grabados de hoy una gran renuncia: el color. Esos leves relieves en papel blanco (los que prefiero), o en un tono metálico uniforme, son pura geonctría; y son la esencia misma de los magiscopios, su principio lineal, su núcleo primero; o también, su proyección, su blanca sombra. Nos gustan por su desnojada nitidez.

ALAÍdE FOPPA

Marcos huerta. Exposición de dibujos recientes, presentada por la Galería Edvard Munch, Paseo de la Reforma 489, del 29 de noviembre al 13 de diciembre.

expo-evento. Exposición presentada por la Casa de la Cultura, Toluca, Méx., el 5 de noviembre.

LEonardo nierman. Exposición presentada por The I. F. A. Galleries Inc., 2623 Connecticut Ave., Washington, D. C., 20008, Dupont 7-7537, E. U. A.

Datos biográficos del artista: Leonardo Nierman, nació en México, D. F., en el año de 1932.

\section{DICIEMBRE}

$10^{z}$ exposición anual de los acuarelistas del instituto de arte de méxico. Presentada por el Instituto Mexicano Norteamericano de Relaciones Culturales, A. C., Galería Nabor Carrillo, Hamburgo 115 , el $1^{9}$ de diciembre. 
Nonibre de los expositores: Rodolfo Aguirre Tinoco, Gustavo Alaniz, Manuel Arricta, Erasto León Zurita, Ma. Teresa Miranda, Martha Orozco, Angel Mauro Rodrigues, Rodolfo van Kurczyn.

Catálogo: 1. espiritu y materia 2. la senda 3. en los albores de la creación $N^{Q} 1$ 4. en los albores de la creación $N^{o} 2$ 5. en los albores de la creación $N^{Q} 3$ 6. la lluvia én las montañas 7. vibración del alba 8. en el cristal del sueño 9. los sueños prolongados 10. la huella del rocío 11. después del día de muertos 12 . el mundo del silencio 13. flor marchita 14. titania 15. pueblo fantasma 16. paisaje de verano 17. autorretrato 18. figuras de muchachas 19. tarde dorada 20. adolescente 21. ajijic 22. callejucla 23. borrio de Tacuba 24 . el caos 25. es el pájaro azul 26. apocalipsis $N^{o} 1$ 27. apocalipsis $N^{o} 2$ 28. apocalipsis $N^{o} 3$ 29. apocalipsis No 4 30. apocalipsis $N^{0} 5$ 31. el grupo 32. guitarra mágica 33 . satcmo 34. atleta 35. pensante 36. paisaje onidico 37. el hechicero 38. la onda verde 39. Susana y Los Viejos 40. rostro.

Fitzin. Exposición de collages y esculturas, prescntada por el Instituto Francés de América Latina, Río Nazas 43 , el $1^{9}$ de diciembre.

FRANCisco tolEDo. Exposición de grabados y viñetas, presentada por la Galería Arvil, Hamburgo 241, el 2 de diciembre.

ignacio m. Beteta. Exposición de obras, presentada por el Salón de la Plástica Mexicana, INBA, Salón Kalder, Hotel Camino Real, el 2 de diciembre.

Carlos mérida. Exposición Homenaje, presentada por la Galería de Arte Mexicano, Milán 18, el 2 de diciembre.

La exposición se efectuó para celebrar sus ochenta años de edad.

ARTE EN el hogar. Exposición presentada por el Departamento del Distrito Federal, Dirección General de Acción Cultural y Social, Galerías de la Ciudad de México, Salas Juárez e Hidalgo, Alameda Central, del 2 al 8 de diciembre.

exposición tres legados culturales. Presentada por el Museo de las Culturas INAH/SEP., Moneda 13, el 4 de diciembre.

Nombre de los expositores: Xenia Zarina (trajes orientales) Fundación Wenner Gren (Arqueología Peruana), William Spratling (Arte Primitivo).

EDMUNDo AQUino. Exposición de tintas y serigrafías, presentada por la Casa del Lago, UNAM, Bosque de Chapultepec, el 9 de diciembre.

HUMBERTo peraza. Exposición presentada por la Casa del Lago, UNAM, Bosque de Chapultepec, el 9 de diciembre.

LESLIE-KRIMS. Exposición de 8 obras maestras de fotografía, presentada por la Casa del Lago, UNAM, Bosque de Chapultepec, el 9 de diciembre.

piro-artesanía de heber romo. Exposición presentada por el Centro de Artes y Humanidades, Insurgentes Sur 1912, el 9 de dicienbre. 
carlos olachea. Exposición presentada por el Departamento del Distrito Federal, Dirección General de Acción Cultural y Social, Galerías de la Ciudad de México, Centro Social Popular, Gral. Ignacio Zaragoza, Av. Oriente 154 y Calle Sur 121, Col. Fscuadrón 201 del 9 de diciembre al 14 de enero.

miguel hernández urbán. Exposición de obras presentada por el Departamento del Distrito Federal, Dirección General de Acción Cultural y Social, Galerías de la Ciudad de México, Centro Social Popular Aquiles Serdán, Puerto Tampico N 4 , Esq. Puerto Guaymas, Ampliación de la Col. Casas Alemán, del 9 de diciembre al 14 de enero.

ÁNGEL BRACHO. Exposición retrospectiva, presentada por el Departamento del Distrito Federal, Dirección General de Acción Cultural y Social, Galerías de la Ciudad de México, Centro Social Popular, José Ma. Morelos y Pavón, Lago Trasimeno y Lago Erne, Col. Pensil, del 9 de diciembre al 14 de enero.

CARTELES INTERNACIONALES SOBRE SEGURIDAD SOCIAL E HIGIENE. Exposición presentada por el Departamento del Distrito Federal, Dirección General de Acción Cultural y Socia1, Galerías de la Ciudad de México, Centro Social Popular Leandro Valle, Av. Sur 8 y Oriente 241, Col. Agrícola Oriental, del 10 de diciembre al 14 de enero.

JEANINE hOUARD. Exposición de dibujos, presentada por el Departamento del Distrito Federal, Dirección General de Acción Cultural y Social, Galerías de la Ciudad de México, Alameda Central, Sala Hidalgo, del 10 de diciembre al 14 de enero.

JBAN IEH MANs. Exposición presentada por el Departamento del Distrito Federal, Dirección General de Acción Cultural y Social, Galerías de la Ciudad de México, Sala Juárez, Alameda Central, del 10 de diciembre al 14 de enero.

Esminio castillo. Exposición de esculturas, presentada por el Departamento del Distrito Federal, Dirección General de Acción Cultural y Social, Galerías de la Ciudad de México, Salas Juárez e Hidalgo, Alameda Central, del 10 de diciembre al 14 de enero.

venta DF navidad. Exposición presentada por la Galería Plástica de México, Londres 139 , el 11 de diciembre.

PAUt VAlíry. Exposición de obras biblio-iconográficas, presentada por la Universidad Nacional Autónoma de México, Instituto de Investigaciones Bibliográficas, Embajada de Francia en México y el Instituto Francés de América Latina, Bibliofeca Nacional, Sala José Mà. Vigil, UTruguay e Isabel la Católica, el 14 de diciembre.

primer salón vacional de l.a estampa. Exposición presentada por el Instituto Nacional de Bellas Artes, Palacio de Bcllas Artes, Salas 1, 2, 3, 4 y 5, del 14 de diciembre al 23 de enero. 
El Salón Nacional de la Estampa, se presenta por primera vez en el Palacio de Bellas Artes con el propósito de auspiciar la labor de los grabadores mexicanos, que se ha incrementado en los últimos tiempos, gracias al respeto que existe en el país hacia la creación intelectual y que ha hecho posible la existencia de todas las tendencias estéticas dentro de nuestra plástica. Por otra parte, trata de propiciar las experiencias de los artistas merced al uso de nuevos materiales y la invención de técnicas y procedimientos que han pernitido trasponer límites que ya resultaban absurdos.

Consciente de esa realidad, el Instituto Nacional de Bellas Artes ha establecido este Salón que viene a suceder al hasta ahora llamado "del grabado", con el deseo de que, dentro de esta nueva denominación, encuentren cabida todas las experiencias que tengan un valor positivo y pudieran resultar de interés para el arte nacional, en el más amplio sentido de creatividad y de aportación al desarrollo de la gráfica.

El arte de la estampa registra un incremento en el mundo, no es por tanto un fenómeno local. Sin pretender establecer definiciones o juicios prematuros, sí podemos afirmar que el arte gráfico resurge hoy más que nunca por la necesidad de que sea disfrutado por un mayor número de individuos; en una sociedad como la nuestra que va aprendiendo a destacar entre la reproducción mecanizada, lo que la mano del artista puede darle en emoción, al diseñar, grabar e imprimir por procesos que ahora pucden parecer primarios, ejemplares que ejecutados uno a uno tienen una edición generalmente limitada.

Tal es, sin duda, el encanto de estas estampas que han logrado sobrevivir independientemente de la imprenta ganando un sitio entre las artes plásticas contemporáneas; su capacidad de producir un goce estético a todo espectador sensible.

Desde hace por lo menos tres décadas, nacieron en México los Salones Anuales de Grabado, que cumplieron en su momento a las necesidades para las que fueron creados. Hoy el INBA se hace eco de las inquietudes de los artistas y seguramente que a través de esta experiencia constructiva, unida a otras promociones realizadas en el presente año, establecerán las bases para una coordinación de ezfuerzos en beneficio del arte de la estampa.

Por lo que podrá observarse en este Salón, la respuesta de los artistas ha sido entusiasta. Si por el momento no se la logrado la participación de todos los que residen en la provincia, consideramos que ello obedece a que es necesario lograr una mayor comunicación. E1 instituto ha incrementado todas sus actividades hacia el interior de la República y sus frutos han de ser más evidentes en un futuro próximo. Es alentador, por tanto, que este Primer Salón Nacional de la Estampa, abra sus puertas con una representación tan importante como la que muestra al público y a la crítica. Estamos convencidos también, de que las mesas redondas y conferencias que se llevaron a cabo durante los meses anteriores en la Sala Manuel M. Ponce, han contribuido a crear el clima de interés y de unidad entre los artistas hacia una meta conlín, que 110 es otra, sino la de servir al desarrollo de la estampa mexicana, cuya lrerencia luminosa es ejemplo de un arte inspirado $y$ fecundo.

Alfredo Guati Rojo 
Nombre de los expositores: Ofelia Alarcón Villegas, Lco Acosta, Alberto Aguilera Galdós, Jesús Alvarez Amaya, Antonio Alvarez Portugal, Raúl Anguiano, Albcrto Antuna Beltrán, José Arellano Fischer, Gustavo Arias Murueta, Martha Alatorre, Octavio Bajonero, Feliciano Béjar, Angel Bracho, Roberto Berdecio, Hilda Campillo, Xavier Campos Calderón. Federico Cantú, Pilar Castañcda, Vita Castro, Guillermo Ceniceros, Thelma Cortés, Erasto Cortés Juárez, Martha Cánovas B., Fermin Chávez, Luis Chacón, Carlos Antonio Chávez, Francisco del Castillo, Antonio Díaz, Federico Diaz Cañedo, Fernando Diaz de la Serna, Arturo Estrada, José Luis Farías, Francisco Fernández Orozco, Fonseca, Iliana Fuentes, Fernando Flores Sánchez, Vicente Gandia, Carlos García Estrada, Rafael Garcia Mazón, Hugo García Pérez, Esther González, Xavier González Iñigucz, Angeles Garduño, Arturo García Bustos, Elena Huerta, Arturo Hinojosos, Sara Jiménez, Paula Lazos, Waldemar Luna, Rina Lazo, Ignacio Manrique, Diana Manzano, Samuel Menache, José Mendarozqueta, Adolfo Mexiac, Carmen Mones, José Luis Martínez Dícz, Héctor Martinez Artcche, Carlos Nakatani, Leticia Ocharán, Pablo O’Higgins, Tomás Ortiz, Ma. Luisa Parraguirre, Arturo Pastrana Vázquez, Jorge A. Pérez Vega, Angel Pichardo, Salvador Pinoncelly, Mariano Paredes, Adolfo Quinleros, Jorge Ramirez, José Ramirez Chavarría, Salvador Romero González, Alberto Rovira Bravo, Froylán Ruiz, José Julio Rodrigues, Mario Reyes, Javier H. Rivera, Ana Salinas, Herber Schmidt Moeldner, Waldemar Sjolander, Albcrto de Trinidad Solis, Ramón Sosamontes, Nunik Sauret, Ma. Teresa Toral, Paulina Trejo, Francisco J. Vázquez, Alfonso Villanueva Manzo, Enrique Jorge Volberg, Angel Zamarripa, Rafael Zepeda.

Catálogo: 1. Composición $N^{0} 1,90 \times 66$ cns. serigrafía 2. composición $N^{p} 2$, $90 \times 66 \mathrm{cms}$. serigrafía 3. rebaño, $60 \times 43 \mathrm{cms}$. litografía en color 4. imagen, $54 \times 40 \mathrm{cms}$. lit. en color 5. dos formas, $57 \times 44 \mathrm{cms}$. lit. en color 6. nido, $57 \times 40 \mathrm{cms}$. lit. en color 7. vision, $49.5 \times 30.5 \mathrm{cms}$. serigrafía 8. hombre y mar, $49 \times 29 \mathrm{cms}$. aguatinta 9. mar, $33 \times 24 \mathrm{cms}$. aguatinta 10 . la mucrte joven, $30.5 \times 46 \mathrm{cms}$. linoleografía en color 11. Juárez, $60 \times 90 \mathrm{cms}$. xilografía 12. autoretrato, $39 \times 69.5 \mathrm{cms}$. xilografía 13. cl macstro Hermilo, $51.5 \times 65$ cnns. xilografía 14. siete a uno, $84 \times 49 \mathrm{cms}$. punta seca 15, sol negro, $84 \times 49 \mathrm{cms}$. aguafuerte 16. diez y ocho, $86 \times 53$ cms. aguafuerte 17. electricus Circus, $48 \times 34.5$ cms. aguafuerte y aguatinta 18. Don Quijote, $39.5 \times 43.5 \mathrm{cms}$. aguafuerte 19. Ballet del Senegal, $34.5 \times 49$ cms. aguafuerte y aguatinta 20. MMBOMB (a) 91 x $66 \mathrm{cms}$, serigrafía y $M M B O M B$ (b), 91 x $66 \mathrm{cms}$. serigrafía 21 QHCTBM, $63 \times 91 \mathrm{cms}$. serigrafía $22 . M, 61 \times 90 \mathrm{cms}$. serigrafía 23. ESSPBM, $63 \times 91 \mathrm{cms}$. serigrafía 24 . guitarrista, $27 \times 27 \mathrm{cns}$. buril 25 . niño $32.5 \times 19$ cms. buril 26. pordioseros, $15 \times 13$ cms. buril 27. cargador, $10.5 \times 14$ cms. buril 28. de la serie suite crótica, $13 \times 20.5$ cms. aguafuerte 29 . de la serie suite erótica, $10.5 \times 20.5 \mathrm{cms}$. aguafuerte 30 . de la serie suite erótica, $15 \times 20 \mathrm{cms}$. aguafuerte 31. mi esperanza, $20 \times 20 \mathrm{cms}$. puntaseca 32. ansiedad, $30 \times 19.5 \mathrm{cms}$. intaglio 33. Ueyiatl Metzintli, $74 \times 53$ crins. xilografía en color 34 . la Médium, $74.5 \times$ $52.5 \mathrm{cms}$. xilografía en color 35. Youalli Meztli, $74.5 \times 53 \mathrm{cms}$. xilografía en color 36. Chalciutl Mestli, $70 \times 50 \mathrm{cms}$. xilografía en color 37, relojes $I, 23.5 \times$ 23.5 cms. intaglio 38. espiral, $23.5 \times 23.5 \mathrm{cms}$. intaglio 39. ruedas magiscópicas, $55 \times 41 \mathrm{cms}$. intaglio 40 pirámide magiscópica, $48 \times 54 \mathrm{cms}$. intaglio 41 . Lázaro Cárdcnas, 47 × 53 cms. litografía 42. Heriberto Jara, 51 × 36 cms. linoleografía 43. los silos, $38 \times 48$ cns. linoleografía 44. Vicente Lombardo Toledano, $50 \times 61$ cms. linoleografía 45. Jonás y la Ballena, $40 \times 50.5 \mathrm{cms}$. mixta 46. composición geométrica, $45 \times 50 \mathrm{cms}$. técnica mixta 47 . geometría dinámica, $28 \times 25 \mathrm{cms}$. técnica nixta 48. geometría maya, $40 \times 25 \mathrm{cms}$. técnica mixta 49. Zcuál pecado? $40 \times 32 \mathrm{cms}$. mixta 50. mar, sol, $28 \times 20 \mathrm{cms}$. técnica mixta 51. hombres, soles, $55 \times 22$ cms. técnica mixta 52. Adán y Eva, $39.5 \times 28 \mathrm{cms}$. técnica mixta. 53 . 
figuri, $72.5 \times 48 \mathrm{cms}$. mixta 54 . tormenta, $285 \times 445$ cnis. punta seca, 55 . Tí, $250 \times 300 \mathrm{~cm}$. punta seca 56. Diana, $300 \times 245 \mathrm{cms}$. punta seca 57. Adan y Eva, $250 \times 300 \mathrm{cms}$. buril 58. capricho floral, $31 \mathrm{x} 41 \mathrm{cms}$, aguatinta y aguafuerte 59. venianas de la ciudad, $52 \times 77$ cms. mixta 60 . máscara, 38 x 47 cms. mixta 61. rincón, 48.5 x 32.5 cms. punta seca 62 . muñecos, 34.5 x $46.5 \mathrm{cms}$. linólco 63. palomas, 24 × 30 cms. aguafuerte y aguatinta 64. pidiendo auxilio, $24 \times 33$ cms. aguatinta 65 . estudio para Maniquies, $23.5 \times 31$ cnis. punta seca 66 estudio fara Maniquies, 23.5 × 31 cms. punta seca 67. estudio para Maniquies, 31 × 24 cms. punta seca 68. estudio para Maniquies, $30.5 \times 25 \mathrm{cms}$. punta seca 69 . composición, 47 x $32 \mathrm{cms}$. mixta 70 . experiencia, $87 \times 41 \mathrm{cms}$, mixta 71 . el Armadillo, $25 \times 77$ cms. mixta 72 . el Búho, 44 × 30 cms. mixta 73. casa de Puerto Principe, Haití, $20 \times 14 \mathrm{cms}$. linoleografía 74. tirada de fruta en Juchitán, Oax., $18.5 \times 16.5 \mathrm{cms}$. linoleografía 75. la civilización contra la guerra, $30 \times 40 \mathrm{cms}$. linoleografía 76. paisaje Juchitán, $26 \times 34.5 \mathrm{cms}$. linoleografía 77 . minotauro (2), $41 \times 26$ mixta 78. el tapiz de Penélope (2), $41.5 \times 20 \mathrm{cms}$. aguafuerte 79. Eros, 41 x 34 cms, aguafuerte 80 . harpía, $40 \times 26$ cms. aguafuerte 81 . autorretrato, $24 \times 28 \mathrm{cms}$. litografía 82.10 de junio $30 \times 40$ cms. linoleografía en color 88. paz, $30 \times 39 \mathrm{cms}$. linoleografía 84. por un Sindicalismo Democrático, 38.5 × 52 cms. linoleografía 85. la juventud lucha, 50.5 x 59 cms. linoleografía 86. Tzompantli (Fete des Morts), $70 \times 89 \mathrm{cms}$. aguafuerte 87 . gallo, $50 \times 40$ cms. mixta 88. díptico, $32 \times 12.5 \mathrm{cms}$. agua fuerte 89 . chango marango, $14 \times 17$ cins. aguafuerte 90 . rostros de una imagen, $27 \times 21$ cms. aguafuerte y aguatinta 91. homolitos, $27 \times 21 \mathrm{cms}$. aguafuerte y aguatinta 92 . objeto sexual, $27 \times 21 \mathrm{cms}$. aguafuerte y aguatinta 93. simbiosis, $27 \times 21$ cms. aguafuerte y aguatinta 94 . sayonara, $45 \times 37 \mathrm{cms}$. xilografía 95. invicrno, $28 \times 43.5$.cms. xilografía 96. Eve's apple, $39 \times 29 \mathrm{cms}$. xilografía 97. Yatai, $23 \times 29 \mathrm{cms}$. xilografía 98. resultado, $27 \times 42 \mathrm{cms}$. aguafuerte 99 . diálogo, $26 \times 44 \mathrm{cms}$. aguafuerte 100 . la espera, $27 \times 42 \mathrm{cms}$. aguafuerte 101 . el silencio, $27 \times 42 \mathrm{cms}$. aguafuerte 102 . el porqué y otras cosas, $22.5 \times 29.5 \mathrm{cms}$. mixta 103. mándala, $27 \times 22.5 \mathrm{cms}$. mixta 104 . Dios nos la dio, Dios nos la quitó, $29.5 \times 36.5 \mathrm{cms}$. mixta 105. las nodrizas de Moisés, $29.5 \times 22.5 \mathrm{cms}$. punta seca 106 . puesto de fruta, $56.5 \times 41.5 \mathrm{cms}$. litografía en color 107. cosas, $60 \times 45 \mathrm{cms}$. litografía 108 . sueño, $60 \times 45 \mathrm{cms}$. litografía 109. frutero, $60 \times 45 \mathrm{cms}$. litografía en color 110 . Blanca, $57.5 \times 40.5 \mathrm{cms}$. serigrafía y xilografía 111. homenaje a Eros, 49.5 x $38 \mathrm{cms}$. mixta 112 . los puentes, $24 \mathrm{x}$ 17 cms. mixta 113. sin título, $25.5 \times 23.5$ cms. mixta 114 . dama en la noche, $29.5 \times 21.5 \mathrm{cms}$. mixta 115 . sin título, $27 \times 20 \mathrm{cms}$. mixta 116 . humania, $40 \times 20$ cms. aguafuerte 117 . estrictura $I, 36.5 \times 25 \mathrm{cms}$. aguatinta 118 . desarrollo ritmico $21 \times 58 \mathrm{cms}$. aguatinta 119. flores con gato, $28.5 \times 37.5 \mathrm{cms}$. mixta 120 . Ja ciudad y las flores, $30 \times 24 \mathrm{cms}$. metal 121. el abraso del tigre, $13 \times 22$ cms. metal en color 122. la mujer y la jirafa, 28 x $49.5 \mathrm{cms}$. metal color 123. alacena, $47 \times 41$ cms. técnica especial 124. te lo juro, $46 \times 29$ cms. técnica especial 125. alli debc vivir Aura, $58 \times 43$ cms. técnica especial 126. vestíbulo, $47 \times 39 \mathrm{cms}$. técnica especial 127. bodegón $N^{o} 8,20.5 \times 18 \mathrm{cms}$. aguafuerte 128 . la noche, $30.5 \times 40 \mathrm{cms}$. intaglio 129. jarra y peras, $30.5 \times 38 \mathrm{cms}$. mixta 130 . bodegón $N^{\circ} 12,28.5 \times 29.5 \mathrm{cms}$. mixta 131 . bodegón $N^{\circ} 11,42 \times 40 \mathrm{cms}$. nixta 132 . resurgir, 53 x $34.5 \mathrm{cms}$. mezzotinta 133. entrelazamiento, 68 × $21 \mathrm{cms}$. mezzotinta 134 . Iuminosidad, 16.5 x $11.5 \mathrm{cms}$. mezzotinta 135. Adán y Eva, $41 \times 27.5 \mathrm{cms}$. linoleografía 136. Clov, 41 x 27 cms. linoleografía 137. Hamm, 36 x $29.5 \mathrm{cms}$. linolengrafía 138. Nell y Nagg, 65 x 35 cms. linoleografía 139. Biafra 3, $21.5 \times 15$ cms. agmafuerte 140. monasterio, Dionisios, Grecia, $20.5 \times 15 \mathrm{cms}$. aguafuerte 141. muro del Quijote, $90 \times 60 \mathrm{cms}$. mixta 142. muro arcaico, $60 \times 90 \mathrm{cms}$. mixta 143. muro de la luna llena, $60 \times 90 \mathrm{cms}$, acrílico 144. las cárceles, $37.5 \times 58.5$ linoleografía 145. el astronauta y la paloma de la paz, 39.5 x $59.5 \mathrm{cms}$. xilografía 146. los amantes, 42 × $32 \mathrm{cms}$. xilografía 147. Cain, 41 x 33 cms. litografía 149. la canasta, $42.5 \times 39 \mathrm{cms}$. aguafuerte y aguatinta 150 . la tolvanera, $48 \times 41 \mathrm{cms}$. barniz suave y resina 151. desnudo hunar, 51 x 33 cms. xilografía 152 . la esquina del crimen, 51 x 51 cms. xilografía 153. Edipo, $30 \times 33$ cms. aguafuerte 154 . cuento manifiesto, $1.00 \times 65 \mathrm{cms}$. aguafuerte 155. López Velarde, $71 \times 61$ cins. 
xilografía 156. zapatistas, 86 x $34 \mathrm{cms}$. xilografía 157. Soledad, 24.5 x $15 \mathrm{cms}$. aguafuerte 158. Jacinto, $18 \times 7.5 \mathrm{~cm}$. intaglio 159. Cave ne Cadas, $15 \times 10 \mathrm{cms}$. aguafuerte 160 mujer, 7.5 x 8.5 intaglio 161 . un rostro suave, $19.5 \times 22.5$ cins. aguatinta 162 . rostro de mi madre, 19.5 x $26.5 \mathrm{cms}$. barniz suave 16.3 maternidad suave, 36 × 27.5, litografía 164. mujer cargando a su hijo, 18 x 32.5 cms. barniz suave 165 . monstrto marino, $15 \times 27 \mathrm{cms}$. linoleografía 166 . monstruo $I I, 15 \times 27$ cms. linoleografia 167 . monstruo $I I I, 15 \times 27$ cms. linoleografía 168. estructuras, $1.90 \times 1.40 \mathrm{mts}$. serigrafía 169 . la celda, $30 \mathrm{x} 40 \mathrm{cms}$. litografía 170. Tikal, 36 x 28 cms. xilografía 171. eclipse, $38 \times 68 \mathrm{cms}$. litografía en color 172. amor eterosex, $43 \times 43$ cms. intaglio 173. amor conjunto, $49 \times 48 \mathrm{cms}$. intaglio 174. goteras emocionales de un $M . D .49 \times 23.5 \mathrm{cms}$. intaglio 175 . paisaje henar subterráneo, $15.5 \times 25 \mathrm{cms}$. intaglio 176 . del azul al verde, $19 \times 15 \mathrm{cms}$. aguatinta 177. sin título, $13 \times 11 \mathrm{cms}$. aguafuerte 178 . retrato, litografía 179. madona, litografía 180. Neutle-Nauta, litografía 181. que no existen, $53 \times 68 \mathrm{cms}$. litografía 182. la lucha por la papa $I, 53$ x $70 \mathrm{cms}$, litografía 183. la lucha por la papa II, 54 x 74 cms. litografía 184 . Freyra, $39.5 \mathrm{x}$ 30 ans. nixta 185 . la selva, $42 \times 32.5$ cms. intaglio 186 . sirenas, 33 x 44 cnis. mixta 187. la torre, $44 \times 47.5 \mathrm{cms}$. intaglio 188 . necrofilia, $24.5 \times 18.5 \mathrm{cms}$. mixta 189. Teresa, 21 x 19 cms. mixta 190. todo terminó con el verano, $15 \mathrm{x}$ 14.5 cms. intaglio 191. tríptico, $10.5 \times 10.5 \mathrm{cms}$. aguafuerte 192 . la paz, $4.5 \times 7.2$ cms. aguafuerte 193. madre $I, 6.5 \times 4.5 \mathrm{cms}$. aguafuerte 194 . madre $I I, 5 \times 4.5 \mathrm{cms}$ agniafnerte 195. pájaro de capa caída, $33 \times 25 \mathrm{cms}$. aguafuette 196 . pájaros nocturnos, 22 × $32.5 \mathrm{cms}$. aguafuerte 197 . pájaro que no sabe a dónde va, $39 \times$ $24 \mathrm{cms}$. aguafuerte 198. el amor de los pájaros, $48.5 \times 29.5 \mathrm{cms}$. aguatinta 199. lacundona, $32 \times 61 \mathrm{cms}$. xilografía 200 . nostalgia, $27 \times 39 \mathrm{cms}$. xilografía en color 201. la primavera llega de noche, $15 \times 52.5 \mathrm{cms}$. linoleografía 202 . la niña del caracol, $40.5 \times 34 \mathrm{cms}$. xilografía 203, en cl mercado de Papantla, 40 x $30 \mathrm{cms}$. litografía 204. ecos, $19 \times 30.5 \mathrm{cms}$. aguatinta 205. nacimiento, $23 \times 12.5 \mathrm{cms}$. aguafuerte y aguatinta 206. climax-H, $27 \times 18 \mathrm{cms}$. aguafuerte y aguatinta 207. tengo mis días de luz intensa, $28.5 \times 27.5 \mathrm{cms}$. mixta 208. sutileza de un día, $18.4 \mathrm{x}$ 54 cms. intaglio 209. imágenes de mil sueños, $19 \times 22.5 \mathrm{cms}$. intaglio 210 . busco la respuesta en mis manos, $19 \times 48 \mathrm{cms}$. intaglio 211 . proyecto $I, 47 \times 47 \mathrm{cms}$. serigrafía 212. proyecto $I I, 45 \times 45 \mathrm{cms}$. serigrafía 213. proyecto $I I I, 46 \times 46 \mathrm{cms}$. serigrafía 214. proyecto $I V, 46 \times 48$ cms. serigrafia 215 . contrapunto (2), $46.3 \times 61$ cms. serigrafía 216 , reposo, $46 \times 57 \mathrm{cms}$. serigrafía 217 . movimiento, $91 \times 55$ cms. serigrafía 218. sin título, $91 \times 55 \mathrm{cms}$. serigrafía 219. selva lacandona, $61 \times 35 \mathrm{cms}$. serigrafía 220 . caballo, $61 \times 35 \mathrm{cms}$. serigrafía 221 . caballos en la playa, $35 \times 61 \mathrm{cms}$. serigrafía 222. Silvia, $36 \times 61 \mathrm{cms}$. serigrafía 223 . casas y amantes, $60 \times 44 \mathrm{cms}$. litografía 224 , reflejo fotográfico, $26 \times 38 \mathrm{cms}$. litografía en color 225 niños, $24 \times 34 \mathrm{cms}$. litografía 226. radiación, $29 \times 35$ $\mathrm{cms}$. litografía 227. conjunción, $33 \times 41 \mathrm{cms}$. litografía 228. protesta bajo el sol, 69 × 39 cms. xilografía en color 229. General Lázaro Cárdenas (homenaje), $55 \times 41 \mathrm{cms}$. punta-seca 230. libertad de expresión, $56 \times 43 \mathrm{cms}$. aguafuerte 232 . velorio, $1.22 \times 1.16 .5 \mathrm{cms}$. xilografía 233. jorobado, $36 \times 56 \mathrm{cms}$. xilografía 234 . rebelión, 36 × $26 \mathrm{cms}$. xilografía 235. Angel Bracho, $25.5 \times 15 \mathrm{cms}$. linoleografía 236. frutero $I I, 80 \times 60 \mathrm{cms}$. linoleografía 237 . ramo de flores, $80 \times 60 \mathrm{cms}$. linoleografía 238. sol verde, $80 \times 60 \mathrm{cms}$. linoleografía 239. Febo, 80 x $60 \mathrm{cms}$. linoleografía 240 . mitin, $46.5 \times 34 \mathrm{cms}$. xilografía 241 . comparsa, $31 \times 28 \mathrm{cms}$. xilografía 242. noche, 17.5 × 13 cms. intaglio 243. la llamarada, 24.5 × 24 cms. intaglio 244. acuario, $49 \times 28 \mathrm{cms}$. intaglio 245 . efigie $y$ danza, $10.5 \times$ $15.3 \mathrm{cms}$. aguafuerte 246. mis dias y las letras, $18 \times 24$ cms. aguafuerte 247. sigilo, 20.5 x $24.5 \mathrm{cms}$. aguafuerte 248. retrato de Francisco Díaz de Lén, $22 \mathrm{x}$ 15 cms. xilografía 249. la modelo, 26 × $20 \mathrm{cms}$. xilografía (camafeo) 250 . bodegón, 21 x $30 \mathrm{cms}$. xilografía 251. variaciones sobre un mismo tema, $93.5 \mathrm{x}$ $54.5 \mathrm{cms}$. mezzotinta 252. por la tarde, $16.5 \times 39.5 \mathrm{cms}$. intaglio 253. mujer $N^{o} 1$, $46 \times 71 \mathrm{cms}$. serigrafía 254. mujer $N^{0} 2,46 \times 71 \mathrm{cms}$. serigrafía 255. hombre $N^{Q} 2,53 \times 76 \mathrm{cms}$. serigrafía 256 . giroscopio, $29.5 \times 24.5 \mathrm{cms}$. xilografía en color 257.. espacial II, $53 \times 25.5 \mathrm{cms}$. xilografía en color 258 . reflejos, $26.5 \times 40 \mathrm{cms}$. 
xilografía en color 259. colorística fundamental, $43.5 \times 40 \mathrm{cms}$. litografía en color 260. hojarasca, $32 \times 43$ cns. xilografía 261 . ceniccro, $32 \times 28$ cms. xilografía 262. olas, $37 \times 50 \mathrm{cms}$. xilografía 263 . alberca, $27 \times 19 \mathrm{cms}$. xilografía 264 . mesa con papeles, $41 \times 54 \mathrm{cms}$. litografía 265 . naturaleza muerta, $56 \times 75 \mathrm{cms}$. litografía 266. sin título, $56 \times 75 \mathrm{cms}$. litografía 267. sin titulo, $56 \times 75 \mathrm{cms}$. litografía 268. Guanajuato, $36 \times 24 \mathrm{cms}$. litografía 269. Janitzio, $27 \times 31 \mathrm{cms}$. litografía y collage 270 . México, D.F., 41 x 29 cms. litografía y collage 271 paisaje bajio, $20 \times 38 \mathrm{cms}$. linoleografía 272 . cantando, $30 \times 40 \mathrm{cms}$. linoleografía 273 . partido del pueblo, $30.5 \times 40 \mathrm{cms}$. linoleografía 274 . cl poeta, $32 \times 37 \mathrm{cms}$. linoleografía 275 . sin título, $34.5 \times 25$ cms. aguafuerte y aguatinta 276 . cuerpo destrozado, $24 \times 20$ cms. aguafuerte y aguatinta 277 . perephenalia en ol putridero, $32.5 \times 25 \mathrm{cms}$. mixta 278 . figuras, $38 \times 39 \mathrm{cms}$. aguafuerte 279 . la alborada de los magos, 56.5 x 36 cms. aguafuerte 280 . la niña del caballo, $44 \times 30 \mathrm{cms}$. aguafuerte 281. máscaras $I, 29.5 \times 22.5 \mathrm{cms}$. aguafuerte y aguatinta 282 . y el niño con mariposas juega, $24 \times 22 \mathrm{cms}$. aguafuerte y aguatinta 283 . sol mágico, $49 \times 32$ cms. aguatinta 284. ciudad hechizada, $48 \times 32 \mathrm{cms}$. aguatinta 285 caballo, pez y barco, 20.5 x 16 cms. aguatinta en color 286 . figura, $26.3 \times 35 \mathrm{cms}$. xilografía (camafeo) 287. el pozo de la consulta, $22 \times 27$ cms. aguatinta en color 288. el saludo, $24 \times 20 \mathrm{cms}$. aguatinta 289 . baño en la tina, $60 \times 50 \mathrm{cms}$. xilografía en color 290. plátano de hueso, 70 x $48 \mathrm{cms}$. xilografía en color 291. dragón, 4.5 x $6.2 \mathrm{cms}$. aguafuerte y aguatinta 292. idolo de la mordida, $24.5 \times 25 \mathrm{cms}$. agua fucrte y agtuatinta 293. ángel s/Sodoma, $24.5 \times 33 \mathrm{cms}$. aguafuerte y aguatinta 294. y los dioses, $24 \times 14.5 \mathrm{cms}$. aguafuerte y aguatinta 295. suave Patria, 29.5 × 39 cins, xilografía 296. porciúncula, 32.5 × 24 cms. grabado al azúcar 297. estudio, $32 \times 24.5 \mathrm{cms}$. aguatinta 298 . mulitas, $32.5 \times 24$ cms. aguatinta 299. diálogo camp, 65 × 50 cms. técnica mixta 300. struktura Mysli $I, 65$ × 50 cms. técnica mixta 301. struktura Mysli $I I, 65$ × $50 \mathrm{cms}$. técnica mixta.

LAUro López. Exposición presentada por la Galería de Arte Mexicano-Florencia, Florencia $35-\mathrm{E}$, el 15 de diciembre.

exposición colectrva. Presentada con obras seleccionadas, por la Galería Rosano, Florencia 32, del 16 de diciembre al 8 de enero.

Nombre de los expositores: Joaquin Clausell, Gregorio Dumaine, Cleofas Almanza, Charles Michel, Mateo Herrera, Pedro Galarza Durán, Edgardo Coghlan, Enrique Benitez, José Zúñiga, Rodolfo Reyes Treviño, Robin Bond, Alicia Wiechers, Getulio.

FIESTA DE NAVIDAD. Exposición colectiva con obras de pintura, dibujo, grabado y escultura, presentada por la Galería José Ma. Velasco INBA/SEP, Peralvillo 55, del 17 de diciembre al 23 de enero.

Nombre de los expositores: Leo Acosta Falcón, Patricia Alconedo, Alvarez Portugal, Raúl Anguiano, Javicr Aréralo, Elizabeth Avila, Héctor Ayala, Octavio Bajonero, Elsa Barragán, Feliciano Béjar, Angel Boliver, Susana Campos, Gerarilo Canti, Angélica Castañeda, Felipe Castañeda, Guillermo Ceniceros, Flaviano Coral, Erasto Cortés Juárez, Julio Chico, Francisco Dosamantes, Irma Escárzaga, Augusto Escobedo, Arturo Estrada, Leopoldo Estrada, J. L. Farias, Ma. Eugenia Galindo, Byron Gálvez, García Bustos, Carlos Gaytán. A. Gómez de Alba, Esther González, Esther Guerrero, Nacho Hernándcz, Hernándes Urbán, Herrera Cartalla, Sarah Iiménez, Rosa Lie Johansson, Macrina Krauss, Rina Lazo, Luis Lemus,. 
Julia Lópes, Lauro López, Leonel Masiel, Eduardo Mata, Angel Mauro, Jesís Montes, Jesuis Morales Aguilar, Teressa Morán, Saúl Moreno, Rogelio Naranjo, José Ma. Nava, Luis Enrique Nava, Ma. Luisa Novelo, Pablo O'Higgins, Froylán Ojeda, Carlos Olachea, Martha Orozco, Mario Orozco Rivera, Tomás Ortiz, Trinidad Osorio, Parra Aguirre, Tomás Parra, Mariano Paredes, Humberto Peraza, Angel Pichardo, David Pimentel, Martha Piña, Yolanda Quijano, Adolfo Quinteros, Jorge Quiroz, Fanny Rabel, Mabel Rabellino, Abel Ramirez, Antonio Ramírez, José Ramos, David Romero de Terreros, Teódulo Rómulo, Alicia Saloma, Sánchez Torres, Alfredo Serrano, Engenio Servin, Adriano Silva, Luis Toledo, Luis Torreblanca, Torres Palomar, Jorge Tovar, Paulina Trejo, Raquel Trejo, Héctor Trillo, Ana Ugalde, Valetta, Van Kurczyn, Raúl Vilchis, Luis Y. Aragón, Puri Yáñez, Guillermo Zapfe, Luis Zárate, José Ziñigiga.

gonzalo cienfuegos. Exposición presentada por la Galería Edvard Munch, Paseo de la Reforma 489, del 17 de diciembre al 10 de enero.

RaÚl anguiano. Exposición de dibujos y grabados, presentada por el Instituto Nacional de Bellas Artes, Museo de Arte Moderno, Bosque de Chapultepec, Galeria de Exposiciones Temporales, Planta baja (salas derecha e izquierda), del 19 de diciembre al 16 de enero.

Raúl Anguiano, que no es propiamente dibujante, sino propiamente pintor, en sus dibujos, por la abundancia y frecuencia de éstos - uno de los aspectos principales de su arte-, no vacila en descubrirnos los arcanos de su labor creadora. Vienen a ser como el pórtico que da acceso a sus obras pictóricas: no, huelga subrayarlo, por constituir, en muchas ocasiones, el brote inicial de las mismas -que no es a los bosquejos a los que nos referimos aquí- sino porque representan, aun aquellos cuya finalidad se cumple en su propia limitación, la urdimbre sobre la cual la obra pictórica se va tejiendo, en superposición lógica, paralela, o -al parecer- independiente.

Estos dibujos muestran lo que es, si no quizá, la más alta calidad que puede poseer un artista, al menos el motor de sus mejores cualidades: la constante insatisfacción. Dibujo tras dibujo, apunte tras apunte; trabajados como si fuera ese momento de los primeros rasgos sobre la hoja en blanco, la hora primera del aprendizaje del pintor. El meticuloso realismo del cstudio cobra así categoría de preordenación.

Margarita NeLken

Raúl Anguiano no necesita presentación. Nacido en Guadalajara, Jalisco, en 1915, empezó a dibujar a los cinco años de edad. De aquellos cuadernillos que aún conserva, aflora una vocación ya definida en apuntes no precisos, nada correctos, pero encantadores en su gracia e ingenuidad evocadoras de una imaginación infantil soñadora y poética. Sus estudios formales con magníficos maestros imprimieron seguridad a su pulso alcanzando tal libertad en la línea y tal elegancia en las composiciones que muy joven ya Raúl fue reconocido como un maestro del dibujo. No se le resistió el color cuyo aprendizaje emprendió con igual fervor y desde el inicio 
de su carrera artística comprende lo que sustentará y lia sido norma general de su obra creadora: que el artista sólo puede crear en plena libertad, sin imposiciones de fórmulas impersonales y llevado tan sólo por su temperamento, su gusto por los temas y su sentimiento estético. De aquí que toda su obra (como pintor, muralista, litógrafo y grabador) responda a una imagen muy personal y sensible de cuanto ha constituido su mundo interno y externo.

Desde sus comienzos, Raúl sobresale como un magnífico dibujante. Tenía el sentido de la línea. Del trazo atrevido, suelto y elegante. Se ha dicho que era la "influencia" de José Clemente Orozco, el gran maestro jaliscicnse, pero es lo cierto que Raúl, aunque admiraba y quería entrañablemente a José Clemente, nunca trabajó con él, no fue su discípulo y mantuvo más íntima relación con Diego Rivera cuando llegado a México (1934) el famoso e inquieto muralista realizaba sus frescos y hacía universal - junto con la obra orozquista- la escuela que ha dado en llamarse mexicana. I'ngresa Raúl en el Taller de Gráfica Popular, que animaban Leopoldo Méndez, Pablo O'Higgins, Alfredo Zalce, Angel Bracho y otros grabadores. Entra en la Liga de Escritores Artistas Revolucionarios (LEAR) y recoge aquí todo lo que el ambiente mexicano de la época recrea: sentimiento político y revolucionario, sensualidad en la textura y el color, novedad en los temas y ese esteticismo que desarrolla con originalidad, pero que no oculta la fragancia de sus raíces que cultiva la obra imperecedera del Greco, la voluptuosa del maniqueísmo goyesco y la impresionista de Cézanne.

LOLO DE LA TORRIENTE

Guardaré un hondo recuerdo de esta exposición de Raúl Anguiano, maestro de las formas exactas y puras, que se sitúan en el espacio como deben hacerlo, en toda claridad y en toda justeza, y con toda la plenitud de su nobleza. Arte noble, sí, y perfectamente mexicano, rotundamente mexicano. $Y$ aquella esencia mexicana - sin elocuencia ninguna ni pintoresquismo- es para mi un motivo suplementario de querer el arte excelso de Anguiano.

Jean Cassou

El año 1967 señala en la obra de Raúl Anguiano el principio de las investigaciones que son testimonio de una nueva voluntad de expresión estética. El punto de mira es la "Venus de Lespugne". Raúl Anguiano realiza, sobre el tema de este pequeño ídolo de la maternidad, aguafuertes, varias litografías e innumerables dibujos que son otros tantos bosquejos constructivos. Anguiano vuelve a blandir la antorcha del Cubismo regenerándolo e infiltrándole un elixir de vida, al mismo tiempo que lo "indianiza". Sus planos se erigen como arquitecturas de una geometría prestigiosa y sensible. Gracias a la iniciativa de un pintor ecuménico, una divinidad de la prehistoria descubierta en un pueblo de Francia, se convierte en hermana de los formidables colosos levantados por los constructores mayas. Sin dejar de ser él mismo, el mexicano Anguiano exalta la unidad interior de la familia humana y de sus creaciones.

Waldemar George. París, 26-X-67 
Datos biográficos dol artista: Raúl Anguiano, pintor, muralista, litógrafo, grabador. En 1915 nace en Guadalajara, Jal., el 26 de febrero. Fstudia pintura en Guadalajara de 1930 a 1934. Se traslada a la ciudad de México, en 1934. Secretario General del Sindicato de Profesores de Artes Plásticas en 1936. Miembro Fundador del Taller de Gráfica Popular en 1936. Pinta murales en la Confederación Revolucionaria Michoacana del Trabajo, en Morelia, Mich., en 1936. Primera exposición en México en el Palacio de Bellas Artes on 1936. Pinta tres murales al fresco en el Centro Escolar Revolución, en México en 1937. Viaja a Cuba donde presenta una exposición de pintura mexicana de la cual forman parte obras suyas en 1938. Hace un viaje a la ciudad de Nueva York y toma un curso de tres meses en The Art Students League. Visita museos y galerías de esa ciudad en 1941. Toma parte en la expedición a la selva lacandona organizada por el Instituto Nacional de Bellas Artes en 1949. Fixposición en el Musco Nacional de Artes Plásticas. El Instituto Nacional de Bellas Artes adquiere íntegra la exposición compuesta por 77 dibujos y litografías en 1949. Viaja a Europa y visita España, Francia, Italia, Inglaterra, Bélgica, Holanda y Alemania. De regreso, la ciudad de Nueva York, en 1952. Exposición en París en 1952. Exposición colectiva de pintura mexicana en París, Fstocolmo, Londres en 1952. Exposición en el Museo de Arte de San Francisco, Cal. EUA. en 1953. Gana un premio en el Salón de Invierno de la Galería, Salón de la Plástica Mexicana en 1953. Gana un primer premio en el Salón de Invierno de la Galería Salón de la Plástica Mexicana en 1955. Toma parte en la Exposición Bienal Internacional de Tokio en 1955. Pinta dos murales en la Cámara Nacional de Comercio de la Ciudad de México en 1955-56. Pinta un mural transportable de $30 \mathrm{~m}^{2}$ para la I Gran Feria del Maíz en Guadalajara, Jal. tema: El Maíz en la Revolución Mexicana en 1956. Exposición de litografías en La Habana, Cuba en 1956. Le es otorgada la insignia José Clemente Orozco por el $\mathrm{H}$. Congreso del Estado de Jalisco, Guadalajara, Jal., en 1956. Toma parte en la Bienal Internacional de Tokio en 1957. Primer premio, Medalla de Oro en el Salón Panamericano de Arte en Puerto Alegre, Río Grande del Sur, Brasil en 1958. Toma parte en la V Exposición Bienal de Litografía a Colores en el Museo de Arte de Cincinnati, EUA, en 1958. XXIX Exposición Bienal de Venecia en 1958. Exposición Intcrnacional de Tokio en 1959. Diploma de Honor otorgado por el Comité de la Exposición Internacional del Libro de Arte (Internationale Buchkunst Ausstellung), Leipzig, Alemania en 1959. Diploma nombrándolo Miembro Vitalicio del Instituto de Recuperación Intelectual de Concepción, República de Chile en 1960. Exposiciones individuales de litografías, dibujos y fetos y murales y cuadros de caballete en Moscú, Leningrado y otras ciudades de la URSS, en 1962. Toma parte en exposiciones colectivas de pintura mexicana en California, EUA. (Los Ángeles, Sacramento, San Diego del Mar), en 1962. Mural transportable de $3 \times 1.30 \mathrm{~m}$. titulado "Nacimiento en la Selva - Fecundidad", realizado para Laboratorios Hormona, S. A., México, en 1962. Es. aceptado como miembro de la Societé Européenne de Culture, Venecia, Italia err 1962. Realiza tres murales para el Museo Nacional de Antropología, México, en 1963. Pinta un mural para Consorcio Químico Mexicano, S. A., Tlanepantla, Edo. de México, tema: "Historia de los Colorantes en México", en 1963. Presea otorgada por el Ayuntamiento de Guadalajara, Jalisco, México, designándole hijo distinguido de la ciudad en 1964. Un mural religioso para la iglesia de San Marcos, Jal., México, titulado "El bautismo de Cristo", en 1964-65. Exposición de pinturas y dibujos er 
Miami, Florida, EUA., 1965. Exposición de pinturas, dibujos y litografías, en Roma, en 1965. Viaja por España, Portugal, Italia, Francia, Grecia, Turquía, Líbano, Siria y Egipto, en 1965. Exposición de pinturas, dibujos y litografías en París, en 1965. Exposición de dibujos y litografías en San Francisco, Cal, EUA., en 1965. Le adquieren varios bocetos y dibujos del nural "La creación del hombre en el mundo maya", Museo Nacional de Antropología Sala Maya, México, para el Museo The Archives for Monumental Art, Lund, Suecia en 1966. Exposición de pinturas, dibujos y litografías en San Antonio, Texas, EUA., en 1966. Profesor-huésped de la Universidad de la Trinidad de San Antonio, Texas, EUA., en 1966. Viaja a Nueva York, Londres, Francia, España, Italia y trabaja durante dos meses en el Atelier Decina de París en litografías a color de 1967 a 1968. Presenta exposiciones de pinturas, dibujos y grabados en París y Roma de 1967 a 1968. Viaja a Nueva York y Baltimore donde presenta sus grabados. Se conpromete a la realización de ediciones completas de grabados. Estudia el movimiento del grabado contemporáneo, en 1969. Exhibición-homenaje (30 años de trabajo) Salón de la Plástica Mexicana, patrocinado por el Instituto Nacional de Bellas Artes, en 1969. Exposición individual en la Galería de Kingston, Jamaica. Es invitado por la Universidad de las Indias Occidentales y patrocinado por la Fundación Ford. Pinta un mural para el Hotel Olympia de Kingston, inspirado en un ensayo del Ballet Nacional de Jamaica. Pronuncia algunas conferencias. Lo acompaña en esie viaje su esposa, la señora Agueda F, de Anguiano en 1970. Exposición individual en Mérida, Yuc., en 1970. Como vicepresidente del Comité Mexicano de Artes Plásticas asiste al Congreso AIAP-UNESCO celebrado en Quito, Ecuador en 1970. Mural en la residencia del scinor Eulalio Ferrer, en la ciudad de México, titulado "la lucha entre el bien y el mal", en 1970. Exposición individual en la Galería Tasende, Acapulco, Gro., México en 1971.

Catálogo: Obra gráfica: dibujos y grabados. La dansa, los viajes y otros trabajos. Tema I, Jamaica 1970 Tema II, Acapulco Tema III, retratos Tema IV, mural del Quijote Tema V, alfareras y Yucatán Tema VI, Europa Tema VII, grabados. Del 1 al 6 . ensayo de ballet, Jamaica, 1970, dibujo a pluma de fieltro, $55 \times 45$ cms. Del 7 al 14 . ensayo de ballet, Jamaica, 1970, dibujo a pluma de fieltro, $60 \times 45$ cms. Del 15 al 20 . ensayo de ballet, dibujo al óleo sobre tela, $1971,1.30 \times 0.90 \mathrm{~m} .21$. Fay, Jamaica, 1970, dibujo con pastel y acuarela, $45 \times 60$ cms. 22. Fay, Jamaica, 1970, dibujo al bistre y acuarela, 60 x 45 cins. 23. Olga, Jamaica, 1970 , acuarela, 50 x $38 \mathrm{cms}$. 24. mujer jamaiquina, 1970, acuarela, 50 x $38 \mathrm{cms}$. 25. Eulah, Jamaica, 1970, dibujo acuarelado, 50 × 38 cms. 26. ensayo de ballet, Jamaica, 1970 , dibujo a pulmón, 45 x $60 \mathrm{cms}$. Del 27 al 33. tequila a go-go, Acapulco, 1967, dibujo acuarelado, $50 \times 39 \mathrm{cms}$. Del 34 al 35. corrida de toros en Acapulco, dibujo a plumón, 38 x $50 \mathrm{cms}$. Del 36 al 37. cabaret barato, Acapulco, 1967 dibujo acuarelado, $38 \times 50 \mathrm{cms}$. 38. cabaret barato, apunte al óleo 1967. Acapulco, $50 \times 75 \mathrm{cms}$. Del 39 al 44. la huerta, dibujo acturelado, Acapulco, $1967,50 \mathrm{x} 38 \mathrm{cms}$. 45. la Hucrta, apunte al óleo, Acapulco, 1967, 50 x $70 \mathrm{cms}$. Del 46 al 48. Tiberio's, Acapulco, 1969, dibujo acuarelado, $38 \times 50 \mathrm{cms}$. 49. Retrato de Rex Nettleford, Jamaica, 1970, dibujo a linta y bistre, $60 \times 45 \mathrm{cms}$. 50. desmudo de negra, Jamaica, 1970, dibujo al carbón y sanguina, $45 \times 60 \mathrm{cms}$. 51. mujer jamaiquina, 1970, carbón y sanguina, $45 \times 60$ cins. 52. hombre Ras Tafarian, Jamaica, 1970 , pastel, $60 \times 45 \mathrm{cms}$. 53 . retrato de Giorgio de Chirico, Roma, 1967, dibujo al carbón, 47 x $32 \mathrm{cms}$. 54 . retrato de Pablo Neruda, París, 1965, dibujo a lápiz, 50 × $35 \mathrm{cms}$. 55. Tetrato de Carlos Pellicer, 1969, dibujo al bistre, 65 x $50 \mathrm{cms}$. 55bis. Juliette Gréco, París, 1967, dibujo a plumón, $45 \times 38$ cms. 56 . estudio para el nural Don 
Quijote: la lucha entre el bien y el mal, 1970, dibujo a plumón, 50 x $64 \mathrm{cms}$. col. Sr. don Eulalio Ferrer 57. estudio para el mural Don Quijote: la lucha entre el bien y el mal, 1970, dibujo a phumón, 50 x $64 \mathrm{cms}$. 58. estudio para el mural Don Quijote: la lucha entre el bien y el mal, 1970, dibujo al bistre, $50 \times 64$ cms. 59. estudio para el mural Don Ouijote: la lucha entre el bien y el mal, 1970, dibujo a plumón, $50 \times 64$ cms. 60. estudio para el mural Don Quijote: la lucha entre el bien y el mal, 1970, dibujo al bistre, 50 x 64 cms. 61. estudio para el mural Don Quijote: la lucha entre el bien y el mal, 1970, dibujo al bistre, $50 \times 64$ cms. 62 . proyecto para el mural Don Quijote: la lucha entre el bien y el mal, $1970,1.00 \times 0.65$, ribujo a la sanguina, col. Eulalio Ferrer 63. estudio de figura, 1969, dibujo a plumón, $50 \times 64.5$ 64. estudio de figuras, 1969 , dibujo a plumón, $50 \times 64.5$ 65. Carole, dibujo a pluma $1966,50 \times 64.5$ Del 66. al 68. alfarera, dibujo a la sanguina, $1971,58 \times 89 \mathrm{cms}$. 69 . alfarera, dibujo a la sanguina, 1971,50 x 65 cins. 70. Carnaby street-Londres, 1967, dibujo acuarelado $60 \mathrm{x} 46 \mathrm{cms}$. 71 Stonehenge - Inglaterra, 1967, dibujo a plumón y crayón, $1.22 \times 0.46 \mathrm{cms}$. 72. Catedral de Amiens, 1967, dibujo a tinta, crayón color, 46 x $60 \mathrm{cms}$. 73. alfarero de Cicul, Yucatán, 1970, sanguina y crayón, 50 x $65 \mathrm{cms}$. 74. Susana Chan, Cicul-Yucatán, 1970, sanguina y carbón, 65 x 50 cms. 75. alfarera maya, 1971, acrílico y papel amate, 65 x 90 cms. 76 . interior de la Catedral de Rouen, 1965, carbón y crayón, 52 x $40 \mathrm{cms}$. 77. sueños de la rasón, litografía, $1968,50 \mathrm{x} 67$ cms. 78 . sueños de la razón, litografía 1971 79. el sucño, litografía, 1971 80. dolientes, aguafuerte a color, $1968,25 \times 19.5$ cms. 81. jugador de jai-alai, tríptico, aguafuerte, $1968,26 \times 68 \mathrm{cms}$. 82. jugador de jai-alai, aguafuerte a color, $1968,26 \times 20.5 \mathrm{cms}$. 83 . danza de la fertilidad, aguafuerte a color, $1969,37.5 \times 29.5$ cnis. 84. desarrollo de Venus, aguafuerte con toques de color, $1969,37.5$ x 29.5 cms. 85 . desarrollo de Venus, aguafuerte y aguatinta, $1969,37.5 \times 20.5 \mathrm{cms}$. 86. alimentos para los astronautas, aguafuerte a color, 196940.5 × 29 cms. 87. figuras de ballet, aguafuerte a color, 1970, 30.5 x 18 cms. 88. ensayo, aguafuerte a color, $1970,30.5 \times 17.5 \mathrm{cms}$. 89 . chapulines, aguafinerte, $1969,22 \times 34.5 \mathrm{cms}$. 90. aparición, aguafuerte realizada con la mano izquierda, $1970,41 \times 32.5 \mathrm{cms}$. 91. figuras del Cairo, aguafuerte, $1969,20 \times 15$ cms. 92. Cristo, aguafuerte y aguatinta, 1969, $34.5 \times 22$ cins. 93. cagnama, aguafuerte y aguatinta, $1968,22.5$ x $34.5 \mathrm{cms}$. 94 . ballet, aguafuerte y ruleta, $1970,30.5$ x $45 \mathrm{cms}$. 95. ballet del Senegal, aguafuerte a color, 1971, $40 \times 44$ cms. 96. ballet del Senegal, aguafuerte y aguatinta, 1971, $35 \times 49 \mathrm{cms}$. 97. electricus Circus, New York, aguafuerte y aguatinta, 1971, 49 x 34 cms. Del 98 al 99. Don Quijote, aguafuerte, 1971, $40 \times 44 \mathrm{cms}$. 100. sueño, aguafuerte, 1971,35 × $50 \mathrm{cms}$. 101. figuras en movimiento, aguafuerte, $1971,50 \times 35 \mathrm{cms}$. 102. Venus, monotipo a color, 1968, 38 x $17 \mathrm{cms}$. 103. Arlequín, monotipo a color, 1968, $38 \times 17 \mathrm{cms}$. 104. Venus flor, monotipo a color, 1968, $38 \times 17 \mathrm{cms}$.

alperto gómez barbosa. Exposición de fotografías de Cajititlán, presentada por la Galería Municipal, Chapultepec y España, Guadalajara, Jal.

Aquí está Cajititlán o Caxitla, tan viva y palpitante como es; desde la gracia intacta de su cielo de azul intenso, blanco y espumoso cuando enmarca la cruz de Lorena o nimba la curva plácida del cerro del Sacramento, hasta el espeso gris tempestuoso de los días lluviosos. En el no siempre quieto espejo de sus aguas la lente vio, la $\mathrm{V}$ de las gaviotas y el éxtasis de las garzas, la estela plateada de los negros patos; aguas tan dúctiles como para que una niña juegue enjuagándolas; se agobian las tardas canoas, los tules se contemplan tan de cerca; $y$, fuera de las aguas, las redes se encogen de tristeza. $\mathrm{Y}$ es, también, sus gentes que tan cerca del progreso, siguen siendo las mismas; así están aquí los pequeños que coro o desde el obscuro fondo de una ventana o los signos marcados en la tierra 
sonríen a la vida; aunque el agua casi los rodea, siguen sintiendo la frescura sobre sus hombros; continuan en la felicidad de la plática, lo mismo hombres que gatos para no decir que aquí no se hace nada; igual que los pericos con parleos y los colores de sus plumas alegres más de algún tiempo ido, cono sigue Don Goyo Virgen sicndo feliz con su burro. Escriben en el agua y los muros los nombres de los amigos y de los enemigos; signos geométricos nada perfectos o las manos en que leen los destinos o signos tan reales e irreales como son los ensueíos.

Está tamlién. la firmeza de sus muros lo mismo en los adobes de tepetatle $y$ cal que desde el siglo xvi dieron fama a Cajititlán; que en sus canteras del cerro del Sacramento tan distintas en textura y colores, pero trabajadas con tal galanura y primor, que parece que al pulirlas -con otra piedra, como aquí era la usanza- lo hacian con dáctiles caricias. Pueblo en que se hermana lo vegetal con lo tclúrico y lo celeste; el arte de sus piedras es tan divino como humano o humano como divino, y no saber ya si este arte tan plateresco en la portada de uno de sus templos, barroca cn sus empréstitos vegetales muestran, en el azoro de los ojos de fieras y ángeles, lo mismo de pagano, indígena o cristiano.

$\mathrm{Y}$ ticne, sobre todas esas cosas, la trinidad de sus Reyes, para Ellos labraron las piedras, para Ellos brillan los cielos y vienen pájaros y nubes, como desde lejos vienen los peregrinos para lucir en lo alto, la trinidad de sus velas. Río de gente al mes de enero a la fiesta de la Fe. La humildad se cubre con rebozo y la virilidad no abandona el sombrero, brillan los ojos, brillan los cirios y brillan los altares; aquí, entonces, todo es un río de luz, de rezos y de gracias; tan se pide como se da; todo termina en los Reyes. Ellos son raíz y fundamento de este Cajititlán que los ve como su Ser, su mundo íntimo y profundo que aquí se descubre y se entrega... después, sigue la alegría de la vida, desde comer pan sencillo y robusto y danzar en las lajas del atrio o seguir complaciente la intimidad de los coloquios, donde ángeles y demonios, Gilas y pastores cifran la lucha de nuestro diario vivir.

Con claros y obscuros aquí está: siente que al proyectarse se ambienta la inagen de sí mismo. Imagen fiel de un pueblo parte de una Patria que aunque fiel a su esencia se hace y rehace a cada instante. Así lo miró el azoro y dejó para siempre; no en la fidelidad fría de un documental, ni un testimonio etnólogo. disfrazado de folklor. Juzgue de la calidad de estas fotografías cada quien como. las viva; ellas son así: un pueblo con su cielo, su lago y su fe; así se te entrega, reacio a tantas cosas pero siempre abierto en su alma tan particularnonte mexicaua como universal, y peregrina a otra Patria, la de la otra Luz, la eterna, a la que también se llega por el agua... Pero contempla ya este pueblo que la gente, tezón y amor hacen llegar a $t i$; quien todos los días ve Cajititlán te invita a acompañar el amigo; ya desde aquí, es una satisfacción su "grata compañía".

Luis M. MÉndez, Pbro.

Datos biográficos del artista: Alberto Gómez Barbosa cuenta a lạ fecha 34 años. Su interés por la fotografía se manifestó desde muy pequeño; fue, sin 
embargo, hasta 1963, cuando su afición tomó cauces más definidos luego de encontrarse con Marcelino Araiza quien fue su maestro en la Escuela de Artes Plásticas de Guadalajara.

Pronto las obras de Gómez Barbosa fueron aceptadas en los salones del Club Fotográfico de México y en el de la Plástica Jalisciense, habiéndose publicado, simultáneamente, en periódicos y revistas especializadas.

Efectúa una exposición en la Casa de la Cultura Jalisciense en junio de 1967 y luego encuentra su esfuerzo en el trabajo monográfico "Cajititlán" que fue presentado en Aguascalientes, Ags. en noviembre de 1970 y que ahora se expone en Guadalajara.

Catálogo: 1. en camino 2. panorámica 3. cruz de Lorena 4. tiene la tarde un árbol 5. la tormenta 6. emigrantes 7. gaviotas 8. éxtasis 9. estela de plata 10. enjuagando las aguas 11. a orillas del lago 12. infinita quietud 13. plácido espejo 14. texturas 15 . encaje sutil 16. frío de enero 17. madrugadora 18. coro infantil 19 . sonriendo a la vida 20 . signos en la tierra 21 . par de vagos 22. aguadoras 23. Juan, el barquero 24. matando el tiempo 25 . en acecho 26. niños y gatos 27. compañero de mi soledad 28. ;vámonos, Platero! 29. amo y siervo 30. si lo sabe Dios... 31. gemelas 32. friso 33. geometría imperfecta 34. hombre y barro 35. ¿Picaso? 36. ángeles o demonios 37. firme, como el ensueño 38. el agua y el tiempo 30. alero 40. fierro forjado 41. cantera del Sacramento 42. textura en muro 43. la niña muerta 44. en la profunda soledad 45. flora y fauna 46. campana mañanera 47, capilla de la Soledad 48. frontispicio 49. lo vegetal y lo celeste 50 . altar de la Dolorosa 51. ¿subimos? 52. día de Reyes 53. peregrinos 54. iya llegamos! 55, plegaria, opus I 56. plegaria, opus II 57. plegaria, opus III 58. los varones 59. la manda 60. familia devota 61. el pan de la fiesta 62. la danza 63. siguiendo los coloquios 64. molcajetero 65. carniccro 66. caña de azúcar 67. terminó la fiesta 68. saeta 69. el pastor 70. el pensador 71. 16 de Septiembre 72. iahí viene el desfile! 73. jviva México! 74. la banda 75. Jinetes 76. el carro de la reyna... 77. ...se descompuso! 78. campanas septembrinas.

Leoner maciel. Exposición presentada por la Fundación Cultural, Miguel Cabrera, García Vigil Núm. 818, Oaxaca, Oax. (durante el mes de diciembre). 
DOI: http://dx.doi.org/10.22201/iie.18703062e.1972.sup1

En la Imprenta Universitaria, bajo la dirección de lorge Gurría Lacruix, se terminó la impresión de Catálogo de las exposiciones do arte en 1971, el dia 18 de julio de 1473. La composición se paró en tipos Old Style 8:10 y 8:8. Se tirarnn 1500 ejemplares. 
DOI: http://dx.doi.org/10.22201/iie.18703062e.1972.sup1 